INTER NATIONAL MONETARY FUND
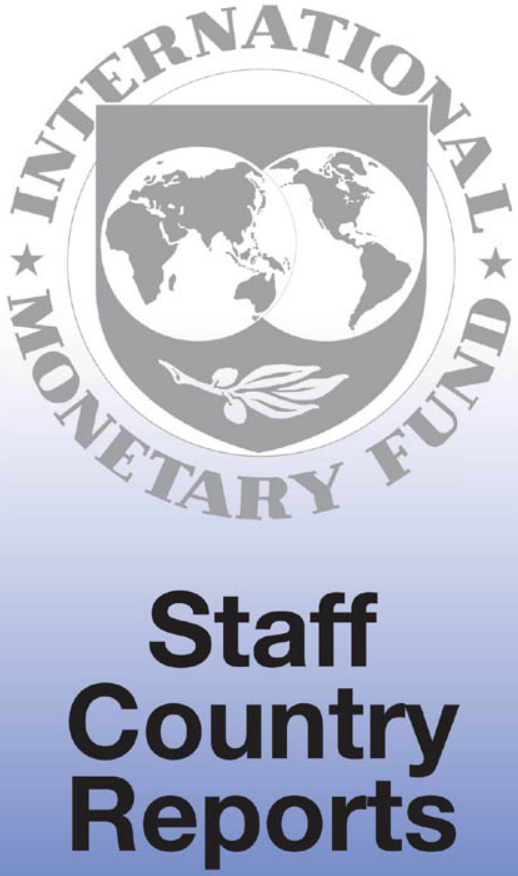


\section{Jordan-Background Information on Selected Aspects of Adjustment and Growth Strategy}

This background paper on Jordan was prepared by a staff team of the International Monetary Fund as documentation for the periodic consultation with this member country.

Copies of this report are available to the public from International Monetary Fund - Publication Services 700 19th Street, N.W. - Washington, D.C. 20431

Telephone: (202) 623-7430 - Telefax: (202) 623-7201 Telex (RCA): 248331 IMF UR Internet: publications@imf.org

Price: $\$ 15.00$ a copy

International Monetary Fund Washington, D.C. 
DOCUMENT OF INTERNATIONAL MONETARY FUND

AND NOT FOR PUBLIC USE

\section{FOR AGENDA}

SM $/ 95 / 218$

CONTAINS CONFIDENTIAI INFORMATION

August 29, 1995

To: Members of the Executive Board

From: The Secretary

Subject: Jordan - Background Information on Selected Aspects of Adjustment and Growth Strategy

This paper provides background information to the staff report on the 1995 Article IV consultation discussions with Jordan and third review under the extended arrangement, which was circulated as EBS/95/140 on August 16, 1995.

Mr. Mansur (ext. 37120) or Mr. McDermote (ext. 36895) is available to answer technical or factual questions relating to this paper prior to the Board discussion.

Unless the Documents Preparation Section (ext. 36760) is otherwise notified, the document will be transmitted, in accordance with the procedures approved by the Executive Board and with the appropriate deletions, to the Arab Monetary Fund (AMF), the European Comission (EC), the European Investment Bank (EIB), the Food and Agriculture Organization (FAO), the Islamic Development Bank (IsDB), and the United Nations Development Programme (UNDP), following its consideration by the Executive Board.

Att: (1) 


\section{Background Information on Selected Aspects of Adjustment and Growth Strategy}

Prepared by a staff team consisting of Messrs. Maciejewski (Head), A. Mansur, C. J. McDermott, J.-P. Chaffour (all MED), E. de Callatay (FAD), and $P$. Alonso-Gamo (PDR)

Approved by the Middle Eastern Department

August 24, 1995

\section{Contents}

I. Introduction

II. The Jordanian strategy to achieve sustained economic growth, $1989-94$

1. Structure of the economy

2. Origins of Jordan's economic difficulties in the 1980 s a. Broad strategy during the 1970s-mid-1980s

b. Macroeconomic outcome: an overview

c. Structural weaknesses

3. Adjustment and structural reform efforts, 1989.94

a. Performance under the 1989-90 adjustment program

b. Performance under the 1992-94 adjustment and reform program

(1) Macroeconomic stabilization and outcome

(2) Structural reforms

4. Overall assessment 3 4 4

III. Macroeconomic environment, growth and investment

1. Economic developments over the period 1976.94

a. The boom of the 1970s 13

b. The slowdown of the early 1980s 13

c. The balance of payments crisis and economic slump in the late $1980 \mathrm{~s}$

d. Macroeconomic stabilization and economic recovery, 1989.94

2. Factors influencing long-term growth

a. An overview

b. Macroeconomic stability and growth

c. Total factor productivity residuals

3. Factors influencing investment 
a. The methodology and data 23

b. Empirical observations

IV. Public Debt Dynamics and Fiscal Policy 26

1. Historical background and the build-up of public debt (1972-88)

\begin{tabular}{lll} 
a. Origin of the problem & 28 \\
\hline b. Debt accounting framework & 29 \\
\hline
\end{tabular}

c. Debt dynamics in Jordan and its sustainability, $1975-88$

2. Shift in fiscal policy stance (1989.94)

a. Debt dynamics and sustainability of the debt ratio 35

b. Revenue mobilization

(1) Taxes on foreign trade

(2) Taxes on domestic transactions

(3) Taxes on income and profits

(4) Nontax revenue

Expenditure

3. Forthcoming structural reforms in the fiscal area

\begin{tabular}{lll} 
a. Reform of the GST System & 40 \\
\hline b. & Tariff reform & 40 \\
\hline d. Income taxation & 40 \\
\hline & Food subsidies & 41 \\
\hline
\end{tabular}

V. Financial Liberalization and Monetary Reforms

41

1. Historical Background and Developments (1970.94)

42

a. A rapid expansion of the financial system, $1970.94 \quad 42$

2. Operation of monetary policy, 1970-88 43

a. Monerary developments 43

b. Public secior driven credit expansion 43

3. Monetary Policy Under Government Stabilization

Programs, $1988-94$

a. lise of monerary instruments 44

b. Banking supervision and regulatory measures 47

4. Development of Amman Financial Market (AFM) 4

5. Ongoing and Prospective Financial Reforms 4

VI. External Det: Strategy $\quad$ Si

1. Background: Emergence of the external debt crisis 51

2 . Debt management strategy after the debt crisis 12

a. The 1989 Paris Club agreement 15

b. Negotiations with the commercial bank creditors 53

3. Changes in dett strategy in the aftermath of the gulf crisis 
a. The 1992 and 1994 Paris Club rescheduling agreements

b. The revised debt strategy vis-à-vis the commercial banks

c. Negotiations with other official creditors 58

4. The medium-term outlook

58

VII. Liberalization of Trade and Exchange System: Jordanian

Experience and Prospects

1. Introduction

2. The structure of Jordan's trade

3. Trade regime and trade policy reforms during 1988-94

a. Trade regime prior to the 1989 reforms 60

b. Policy changes in the trade regime during 1988-94

4. A strategy for further trade liberalization 63

5. Opening up the economy: joining the World Irade Organization (WTO) and agreement with the European Union (EU)

6. Regional developments and future challenges 66

7. Developments in the Exchange System 66

VIII. Social Aspects of the Adjustment Program: Strengthening of the Social Safety Net in Jordan

1. Introduction

2. Poverty profile: pre- and post-1989 situation

a. Developments in poverty and income distribution, 68 pre-crisis situation
b. Dimensions and distribut 68 crisis period (1991-92)

c. Why povercy deteriorated: economic decline and redistribution

3. Poverty alleviation policies

a. Temporary social safety net instruments

(1) Food subsidy schemes

(2) The National Aid Fund (NAF)

(3) Healthcare subsidies

(4) Other welfare programs

4. Permanent social safety net arrangements 76

a. Public education system 17

\begin{tabular}{ll}
\hline b. Public health system & 77 \\
\hline
\end{tabular}

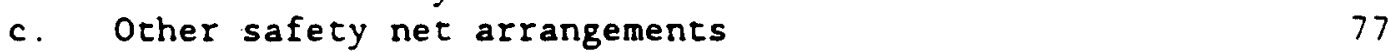

5. Overview of recent developments and medium-term 
Text Tables

1. Macroeconomic Performance, 1976-95

2. External Financing and Investment, 1976.94 14

3. Summary of Estimated Panel Regression Coefficients from a Growth Accounting Framework

4. Impact of Macroeconomic Policy on Real GDP Growth, $1976-94$

5. Contributions to Economic Growth by Factors of Production, $1976-94$

6. Estimates of Private Investment Equation, 1977-94

7. Central Government Operations, 1975-94

8. Fiscal Sustainable, 1975.94

9. Fiscal Impulse, $1975-94$

10. Comparative Performance of Emerging Capital Markets, 1994

11. Selective Poverty Indicators, $1986 / 87$ and 1992 48

12. Factors Contributing to Change in Poverty, Selected Time Period

13. Food Subsidies, 1988-94

14. Selected Countries: Expenditure on Education and Efficiency

15. Health Indicators, 1991

\section{Appendices}

I. Methodology of Debt Dynamics Accouriting Framework

II. Money Demand Functions

III. Money Multiplier and Reserve Money. 1980.94

69

IV. The 1989-90 Banking Prices

$v$. Monetary Program Under Indirect Monetary Control

VI. Social Security Corporation

Appendix Tables

16. Sensitivity of the Monetary Program to Selected Parameters

17. Assets and Liabilities of the Social Security Corporation, 1987-91

\section{Statistical Appendix Tables}

18. Industrial Origin of Gross Domestic Product at Current Prices, 1989.94

19. Indistrial Origin of Gross Domestic Product at Constant 1985 Prices, 1989-94 
20. National Expenditure Accounts in Current Prices, 1989.94

21. Agricultural Production, 1989-94

22. Output by Major Industries, 1989-94

23. Construction Activity in Jordan, 1989-94

106

24. New Registrations and Capital Investment, $1989 \quad 107$

25. Cost of Living Index, 1989-94

108

26. Domestic Retail Prices of Petroleum Products,

Selected Years

27. Government Finances, 1989-94

28. Government Revenue, 1989-94

29. Government Expenditure 1989-94

30. Central Government Budget--Capital Expenditure and Net lending by Function, 1989.94

31. Imports of Crude $0 i 1$ and Oil Products by Sources, $1991-94$

32. Food Subsidies, $1989-94$

33. Food Subsidies, 1994

34. Central Government Domestic Bank Financing by Sources, $1989-94$

35. Outstanding Public Sector Domestic Debt, 1989-94

36. Factors Affecting Changes in Money Supply.

$$
1989.94
$$

37. Monetary Survey, 1989.94

38. Balance Sheet of the Central Bank of Jordan, 1989.94

39. Consolidated Balance Sheet of Commercial Banks and

the Housing Bank, 1989-94

40. The Interest Rate Structure and Recent Government Bond Issues, 1989.94

41. Commercial Banks' Liquidity and Reserves, 1989-94

42. Consolidated Accounts of the Specialized Credit Institutions, 1989.94

43. Outstanding Loans of Specialized Credit Institutions, 1989.94

44. Sectoral Distribution of Outstanding Credit to the Private Sector from Commercial Banks and the Housing Bank, 1989.94

45. Amman Financial Market Indicators, $1989.94 \quad 128$

46. Balance of Payments, $1989.94 \quad 129$

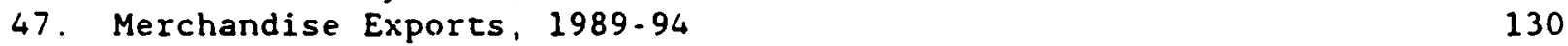

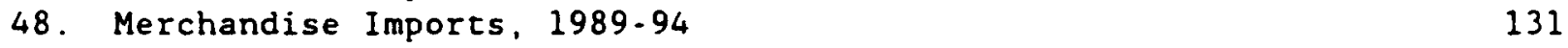

49. External Services Accounts, 1989-94 132

50. Net Foreign Assets of the Banking System, 1989-94 133

51. Terms of Trade, 1989-94 134

52. Composition of Imports (SITC Classification), $1989-94$ 
55. Disbursement of Public and Publicly Guaranteed Loans, 1990-94

56. Outstanding External Debt, End-December

57. Service Payments on External Debt, 1989-94

Charts

1. Structure of the Economy

$4 a$

2. Movements in Monetary Aggregates, Prices and the

Exchange Rate

3. Central Government Operations

$4 b$

4. Central Government Operations

5. External Sector

6. Exchange Rate Indices, 1988-95

7. External Debt and Debt Service, 1990-2000

8. Real GDP Growth and Investment, 1977-94

$4 c$

9. Real GDP Growth, Fiscal Balance, and

Current Account, 1977-94

10. Fiscal Balance, 1972.94

$4 d$

11. Expenditure, 1972.94

12. Tax Revenue, 1972-94

$4 e$

13. Nonmilitary Current Expenditure, 1972-74 $28 \mathrm{C}$

14. Debt to GDP Ratio, 1974.94

15. Evolution of Debt to GDP Ratio, 1975.94

$6 a$

16. Fiscal Impulse Breakdown, 1975-94

17. Implicit Interest Rate and Economic Growth Rate, $1975-94$

18. Revenue and Grants, 1972.94 $\frac{6 b}{16 a}$

19. Monetary Aggregates, 1970.94 $16 a$

20. Prices and Interest Rates, $1970-94$ $16 b$

21. Broad Money Demand, 1980.94 $28 a$

22. Income Velocity of Money, $1970-94$ $28 \mathrm{~b}$

23. Quarterly Demand for Money, 1981-94

24. Currency Outside Banks, 1980-94 $28 \mathrm{c}$

25. Banks' Cash in Vaults and Reserve Requirements, 1980.94 $30 a$ $32 a$ $32 b$

26. Licensed Banks' Excess Liquidity, 1980-94

$3 \dot{a} \mathbf{a}$ $36 a$

$42 b$

$46 a$

$86 a$

$86 \mathrm{~b}$

$85 \mathrm{c}$

$88 a$

$88 \mathrm{~b}$

$90 a$

Text Box 1

$42 a$ 
Jondan: Buic Date $y$

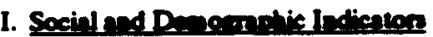

Mot Reat Futing)

Ans

892 dromand aq. ton.

GNP paranin (1923)

USS1,334

Pooulationcharcentiven

Life expetangy at bind (ven)

Crude bin't wese (per thomand)

Conde death rele (per thomand)

Infent eorrilioy mee

(per tromand)

\section{Aresingense}

14 and under

15-64

Urtase

Rural

Axme lo enie meter ed elemicio

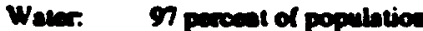

Elacticing. 99 pereeal of popplation
Poonintion

42 nition (1993)

Rave of promt (153-93) 60 pavent

per ansuar

Danity

21 per eq. $\mathrm{km}$.

66.6

330

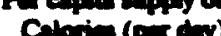

Prowion (rome per dy)

2,907

79

412

P.to:1

Henle

41.9

SSS

78

2

Popelatice per phyacias

(bomand)

Popalation per boupital

bed (thomened)

1.9

1.8

Education

Enrolleat nite:

Prinary

Sacondary

Pupil-tencher ntio:

Prieny

Secondary
99

79

22

19

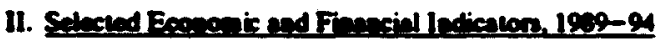

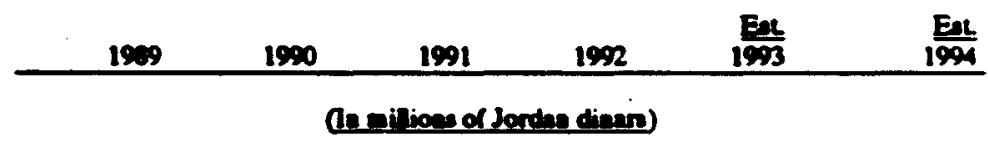

National imacose

Nowinal GDP at eartet prices

Noniand GDP at fector cont

23722

2.102 .6

$-106$

Real GDP at metret pien

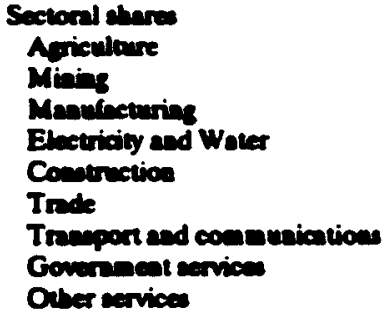

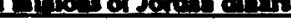

$20033550 \quad 3.4930 \quad 35025 \quad 42662$

$\begin{array}{lllll}2.3245 & 2505.6 & 2.5609 & 3.3012 & 3.6221\end{array}$

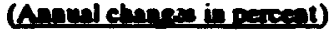

$18 \quad 16.1$

58

5.8

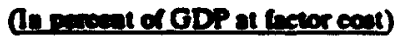

$\begin{array}{rrrrrr}6.6 & 8.1 & 8.5 & 8.3 & 8.3 & 8.0 \\ 7.3 & 6.4 & 5.0 & 4.4 & 3.3 & 3.1 \\ 12.1 & 14.9 & 13.7 & 13.7 & 13.7 & 14.4 \\ 25 & 2.3 & 2.5 & 22 & 2.1 & 2.1 \\ 4.8 & 4.5 & 5.0 & 7.3 & 7.6 & 7.4 \\ 8.6 & 9.3 & 10.2 & 9.4 & 9.5 & 9.7 \\ 17.0 & 15.6 & 15.3 & 152 & 15.0 & 15.7 \\ 20.4 & 19.3 & 18.9 & 18.7 & 19.5 & 19.2 \\ 20.6 & 19.6 & 20.9 & 20.7 & 21.0 & 20.4\end{array}$


Jerdn: Penic Date (continued)

Consumption

Grom entional seving

Grom fred investument
Prices

GDP defintor

Cout of living inder

Import price index

Epart price index

Government budget

Toul revenue and foreign prants

Reveave

Fartipg grats

Total ependiture and set leadias

Curreat expeadieure

Copital expeaditure

Net lending

Exirabudectary eqeaditure and dincrepangy

Ovarall belance (excluding poose)?

Overall balnece (includiag pranu) 3

Finnacine

Forate (ca)

Domentic (ect)

Beaking Gutem

Noobent earrees

Ouane in overdve oblipatione

Total reveaue and foreign grans

Reveoue

Foreigre grante

Toul epeaditure and net leadine

Orreat bulance

Oversll balance (excluding foreign prants)

Primary balance (ereludiag foreign ronta)?

1989

1990

1991

1992

Est.

Est.

(In pexcent of nomind GDP)

$\begin{array}{rrrrrr}95.0 & 99.0 & 97.4 & 98.5 & 98.8 & 96.7 \\ 8.6 & 3.3 & 5.0 & 13.4 & 14.2 & 14.6 \\ 23.4 & 26.0 & 23.7 & 30.0 & 31.8 & 27.4\end{array}$

(Annuletennes in percent)

$\begin{array}{rrrrrr}21.0 & 11.4 & 52 & 5.4 & 5.1 & 3.9 \\ 25.7 & 16.2 & 8.2 & 4.0 & 3.3 & 3.5 \\ 45.1 & 36.6 & 0.2 & -5.5 & 1.6 & 2.7 \\ 56.1 & 19.0 & 11.3 & -3.7 & 1.0 & 4.8\end{array}$

(In millions of Jordnn dinars)

\begin{tabular}{|c|c|c|c|c|c|}
\hline $\begin{array}{l}8695 \\
5652 \\
3043\end{array}$ & $\begin{array}{r}1,0065 \\
734.8 \\
291.7\end{array}$ & $\begin{array}{r}1,0528 \\
8052 \\
247.6\end{array}$ & $\begin{array}{r}1.3064 \\
1.169 .0 \\
137.4\end{array}$ & $\begin{array}{r}1,3324 \\
1,165.8 \\
166.6\end{array}$ & $\begin{array}{r}1,389.8 \\
1244.5 \\
145.3\end{array}$ \\
\hline $\begin{array}{r}1,0538 \\
890.0 \\
196.4 \\
16.2\end{array}$ & $\begin{array}{r}12238 \\
9762 \\
1595 \\
22\end{array}$ & $\begin{array}{r}1,30016 \\
1,0081 \\
167.7 \\
-35.8\end{array}$ & $\begin{array}{r}1.288 .6 \\
1.100 .1 \\
203.1 \\
-152\end{array}$ & $\begin{array}{r}1.381 .6 \\
1.154 .9 \\
248.7 \\
-22.0\end{array}$ & $\begin{array}{r}1,4967 \\
1244.3 \\
271.6 \\
-19.2\end{array}$ \\
\hline-48.8 & 85.9 & 140.6 & -- & -- & - \\
\hline-4886 & -489.0 & -495.4 & -119.6 & -215.8 & -2522 \\
\hline-1361 & -1973 & -247.8 & 928 & 25.3 & -12.8 \\
\hline $\begin{array}{r}136.1 \\
90.6 \\
17.2 \\
21.1 \\
-3.9 \\
28.3\end{array}$ & $\begin{array}{r}197.3 \\
2105 \\
-101.9 \\
-1225 \\
20.6 \\
88.7\end{array}$ & $\begin{array}{r}247.8 \\
24.0 \\
-61.4 \\
-90.7 \\
29.3 \\
2852\end{array}$ & $\begin{array}{r}-92.8 \\
392 \\
100.8 \\
85.8 \\
15.0 \\
-1229\end{array}$ & $\begin{array}{r}-25.3 \\
152.7 \\
-13.8 \\
-28.8 \\
15.0 \\
-202\end{array}$ & $\begin{array}{r}12.8 \\
41.1 \\
-3.8 \\
\ldots\end{array}$ \\
\hline
\end{tabular}

(In percent of GDP at current market prices)

$\begin{array}{rrrrrr}30.6 & 38.4 & 36.9 & 37.4 & 34.3 & 32.4 \\ 23.8 & 27.5 & 28.2 & 33.5 & 30 & 29.2 \\ 12.8 & 10.9 & 8.7 & 3.9 & 4.3 & 3.4 \\ 44.4 & 45.9 & 45.6 & 36.9 & 35.6 & 35.1 \\ -13.7 & -9.0 & -7.8 & 2.0 & 0.3 & 0.0 \\ -20.6 & -18.3 & -17.4 & -3.4 & -5.6 & -5.9 \\ -11.1 & -8.0 & -6.8 & 5.7 & 0.9 & -0.4\end{array}$


Jorin: Buric Den (contineed)

Moncy and quari - noeny

Monoy

Foride anev (Eet)

Domenic ance (Eet)

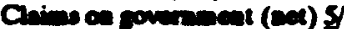

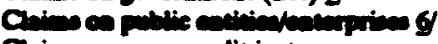

Chins os epece. endit inet.

Chins os finneial compniv.

Chimo on privete rector

Orver ivese (Bet) y

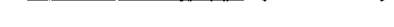

\begin{tabular}{llllll}
1909 & 1990 & 1991 & 1992 & $\frac{E 1}{1993}$ & $\frac{\text { Ell }}{1994}$ \\
\hline
\end{tabular}

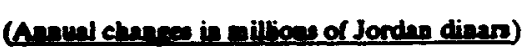

\begin{tabular}{|c|c|c|c|c|c|}
\hline $\begin{array}{r}227.6 \\
145.7 \\
319.1 \\
8.5 \\
21.2 \\
-13.3 \\
-3.6 \\
7.6 \\
101.5 \\
-104.9\end{array}$ & $\begin{array}{r}150.9 \\
105.6 \\
259.7 \\
-102.8 \\
-120.8 \\
-0.8 \\
-20 \\
-16.5 \\
135.0 \\
-75.1\end{array}$ & $\begin{array}{r}763.9 \\
179.7 \\
778.4 \\
-14.5 \\
76.6 \\
14.2 \\
-7.8 \\
-9.5 \\
892 \\
-1772\end{array}$ & $\begin{array}{r}303.6 \\
105.8 \\
12.0 \\
296.6 \\
85.8 \\
-6.0 \\
-2.5 \\
10.1 \\
236.3 \\
-27.1\end{array}$ & $\begin{array}{r}288.9 \mathrm{y} \\
14.1 \mathrm{y} \\
-50.8 \mathrm{y} \\
329.7 \mathrm{y} \\
-28.3 \mathrm{y} \\
43.5 \mathrm{y} \\
--4 \\
35.6 \mathrm{y} \\
259.8 \mathrm{y} \\
-12 \mathrm{y}\end{array}$ & $\begin{array}{r}359.7 \\
16.0 \\
65.6 \\
294.1 \\
-57.3 \\
45.0 \\
-- \\
17.0 \\
453.7 \\
-164.3\end{array}$ \\
\hline
\end{tabular}

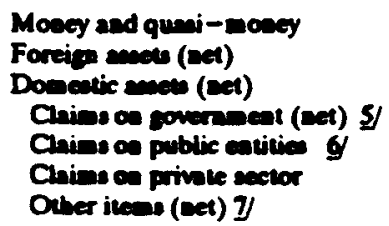

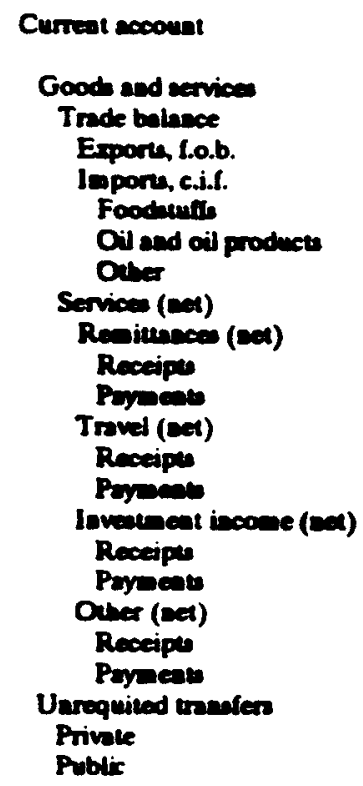

Capital acomet

Public eaceor

Dimburseneate

Payseate

Privile ackor (bet)

Cows of reatrueturias

Trasules of worters' soving

Erron aed ominione

Overall balance

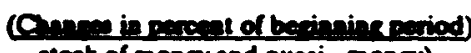

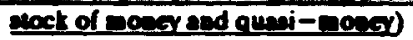

12.4
12.1
0.3
0.8
-0.5
3.8
-3.8

$\begin{array}{rrr}5.1 & 24.5 & 7.9 \\ 8.7 & 24.9 & 0.3 \\ -3.7 & -0.5 & 7.6 \\ -4.1 & 25 & 22 \\ -- & 0.5 & -0.2 \\ 45 & 2.9 & 6.1 \\ -32 & -6.2 & -0.5\end{array}$

$\begin{array}{rr}6.9 y & 8 \\ -124 & 1.5 \\ 8.14 & 6.6 \\ -0.74 & -1.3 \\ 14 y & 1 \\ 6.94 & 10.1 \\ 0.84 & -3.3\end{array}$

\section{(e rilioes of U.S. dollars)}

\begin{tabular}{|c|c|c|c|c|c|}
\hline-104 & -754 & -712 & -741 & -650 & -399 \\
\hline-733 & -1.176 & -897 & -1247 & -1.005 & -725 \\
\hline-1.288 & $-1,668$ & -1.439 & $-2,119$ & -2293 & $-1,950$ \\
\hline 1.110 & 1.064 & 1,132 & 1200 & 1.248 & 1.424 \\
\hline 2396 & 2,732 & 2571 & 3,339 & 3541 & 3.374 \\
\hline 360 & 609 & 613 & 612 & 628 & 586 \\
\hline 415 & 146 & 430 & 46 & 4SA & 430 \\
\hline 1.614 & 1.657 & 1.588 & 2281 & 2.459 & 2358 \\
\hline 555 & 493 & $S 43$ & 873 & 1,268 & 1225 \\
\hline 533 & 430 & 309 & 741 & 962 & 1.000 \\
\hline 023 & 590 & 450 & 800 & 1.040 & 1.093 \\
\hline 91 & 7 & 61 & 8 & 78 & 93 \\
\hline 126 & 176 & 35 & 112 & 218 & 188 \\
\hline 517 & 512 & 317 & 462 & 563 & 58 \\
\hline 102 & 336 & 20 & 350 & 345 & 394 \\
\hline-325 & $-4 R$ & -362 & -335 & -310 & -315 \\
\hline 40 & 67 & 114 & 112 & 99 & 73 \\
\hline 425 & 470 & 477 & 44 & 409 & 388 \\
\hline 202 & 209 & 481 & 381 & 398 & 306 \\
\hline 693 & 936 & 1,036 & 935 & 1.011 & 629 \\
\hline 412 & 647 & SSS & 604 & 613 & 323 \\
\hline 629 & 42 & 185 & 506 & 375 & 326 \\
\hline 30 & 29 & 21 & 158 & 35 & 2 \\
\hline $\operatorname{seg}$ & 393 & 164 & 348 & 340 & 324 \\
\hline-390 & -362 & 73 & 151 & -147 & -54 \\
\hline-300 & -431 & -672 & -337 & -415 & -271 \\
\hline 574 & 439 & 135 & 335 & 155 & 242 \\
\hline 954 & -871 & -806 & -672 & -570 & -513 \\
\hline-19 & 69 & 26 & 45 & 20 & 26 \\
\hline & -- & -- & -158 & 230 & -35 \\
\hline-- & 112 & 719 & 600 & 480 & 226 \\
\hline 8 & 243 & 372 & 100 & 226 & 17 \\
\hline-421 & -760 & -267 & -488 & -571 & -430 \\
\hline
\end{tabular}


Jexdan: Pnic: Dete (continued)

\begin{tabular}{|c|c|c|c|c|c|}
\hline 1909 & 1990 & 1991 & 1992 & $\frac{\text { Est. }}{1993}$ & Est. \\
\hline \multicolumn{6}{|c|}{ (In pexcent of GDP) } \\
\hline $\begin{array}{r}-25 \\
-103\end{array}$ & $\begin{array}{l}-19.1 \\
-18.9\end{array}$ & $\begin{array}{r}-17.0 \\
-6.4\end{array}$ & $\begin{array}{r}-14.4 \\
-9.5\end{array}$ & $\begin{array}{l}-11.6 \\
-102\end{array}$ & -7 \\
\hline
\end{tabular}

Orrent eccount balance 8 Overall balapere

(In million of U.S. doller: unlea indiened abeace)

Gros offoial reacrea 9 (end of pariod)

(iv econtre of imports)

Outenndiag ecterul public debt (and of paived)

(e pacent of ODP)

Entereal public debt cervice

(es percent of eqports of roods and rervices)

Exchange rate (USADD) (pariod averese)

Percestare change in real efiective exchange role 10 (-depreciation)

480
02
612
157
13284

24.9

1.7532

15000

1.4689

1.4712

1.4434

1.4312

4312

6651

108.9

831.0

$22.4 \quad 19.9$

$-15.6 \quad-3.0$

1.1

0.8

$-02$

0.6

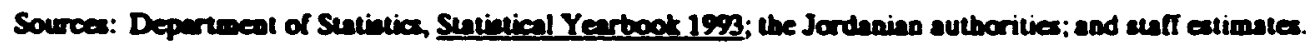

$y$ Eart Bank oaly.

2 Commitmeat benin

3 Conb beniz.

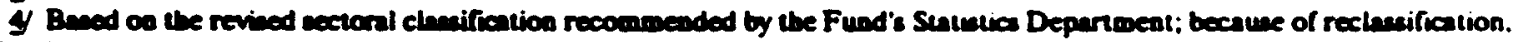
the changes shown usder this colume my ex be meaningtul.

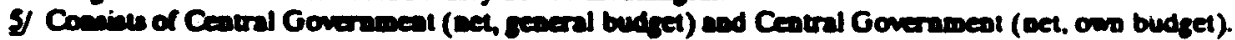

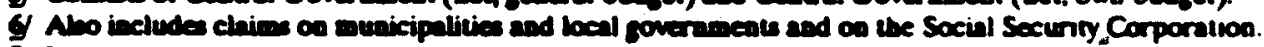

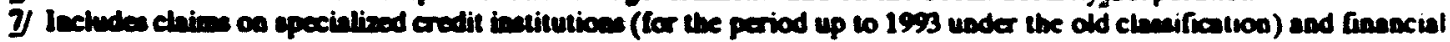
institution.

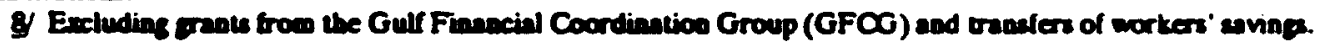

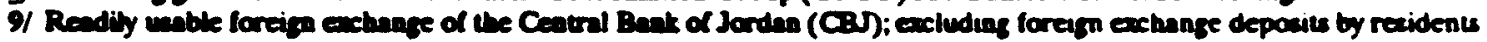
at the Ceotral Bank of Jordan, gold, and chimes on the Ceatral Bank of lreq; dact are for ead of panod.

10 Period overage; depreciation (-). 


\section{Introduction}

Jordan has achieved over the past few years major progress in macroeconomic stabilization and tranaformation in its economic structure. Its impressive performance was the result of a peraistent, courageous, and difficult process of adjustnent and reform program that started in 1989 and was intensified since 1992. The Fund has been associated closely with the process of adjustment and reform carried out in Jordan since 1989. The association has been reflected in the stand-by arrangenents of 1989 and 1992, and currently the extended arrangement that was approved in May 1994. The papers presented in various chapters of this background study have been prepared by staff nembers who participated in the process of cooperation between Jordan and the Fund over the last three years.

This volume does not seek to present a complete description of policies and developments, but rather focuses on some central aspects of the Jordanian experience of recent years. Included are discussions on macroeconomic policies and developaents; an analysis of structural reforms in key areas, such as fiscal, financial system, and trade and exchange regime. Jordan's external debt management strategy, as well as the dynamics of public debt and Its sustainability--taking into account the recent stance of fiscal policy--are also discussed.

Section II deals with the key developments in the Jordanian economy since 1989 compared with 1 ts developments in the 1970 s and 1980 s. It presents an overview of Jordan's econonic structure, policies and developments, particularly since 1989, and provides a setting for the issue oriented discussions of other sections. While highlighting Jordan's recent success, it stresses the importance of appropriate financial policies and structural reforms, together with extermal financial support, for achieving sustainable economic growth.

Section III reviews the relationship between macroeconomic environment and investment and growth. Specifically, this section reviews Jordan's growth and inflation performance over the last two decades; compares this performance with the prevaling axcroeconomic environment measured in terms of selected indicators; and explores the link between Jordan's macroeconomic performance and developments in private sector investment and growth.

Section IV analyzes Jordan's public debt dynamics and the stance of central government fiscal operations. It describes: the evolution of Jordan's fiscal imbalances and the growth of public debt in terms of a debt dynamics accounting framework, the fiscal adjustment and reform efforts since 1989, and the implications of these efforts for the sustainability of the public debt. The medium-term fiscal issues that bear on the sustainability of Jordan's public debt in the longer term are also discussed in this section. 
Section $V$ addresses developments in the financial sector during 1970-94. It reviews the use of monetary policy instruments until late 1980s, the use of these monetary policy instruments under the stabilization program since 1989, and Improvements in banking supervision and in the regulatory environment. The section concludes with a review of the ongoing and prospective financial reforms.

Section VI deals with Jordan's external debt strategy. It focuses on the steps taken since 1989 to alleviate Jordan's official bilateral debt and commercial bank debt burden. This section discusses the key elements of the approach, which together with sustained implementation of appropriate economic policles have made toward improving Jordan's medium-term debt and debt service outlook.

Section VII supplements the discussion on developments in the external sector policies by reviewing the reforms undertaken in recent years to liberalize the trade and exchange systems. In particular, the section highlights the substantial reduction of tariff barriers undertaken during 1988-94, measures to promote exports, and the author1ties' current strategy for further trade liberalization.

Section VIII focuses on the effects of the 1989 balance of payments crisis on Jordan's poverty profile, and on the social aspects of the adjustment program, including the program's soclal safety net instruments. This section analyzes the extent and distribution of poverty in the post-crisis perlod, and discusses the poverty alleviation policies adopted by the Govermment. It reviews the mechanism by which (both temporary and permanent) social safety net instruments were strengthened or established to protect the poor and vulnerable segments of the population during the adjustment and reform period. This section concludes with a review of the Government's safety net programs in terms of their cost effectiveness and sustainability from the budgetary point of view.

\section{The Jordanian Strategy to Achieve Sustained Economic Growth. 1989-94}

In recent years, Jordan has made major progress toward achleving macroeconomic stabilization and achieving sustained economic growth. Jordan's remarkable success in achieving high real growth with continued price stability and a strengthening of balance of payments is attributable to the Government's stabliliation and reform strategy adopted in the wake of the balance of payments crisis of the late 1980s. The strategy was further strengthened in the aftermath of the August 1990 reglonal crisis when 300,000 Jordanians (about 10 percent of the population) returned from neighboring countries leading to a sharp increase in unemployment, disruption of trade, loss of remittances, and stoppage of aid flows from regional countries. 
This section provides a background analysis covering the structure of the economy, the sources of Jordan's econonic difficulties, and recent adjustment and reform efforts. The analysis focuses on two sub-periods. The emergence of financial imbalances in the 1980 s and the adjustment and reform efforts since 1989, which were supported, inter alia, by two stand-by arrangements and an ongoing extended arrangement with the Fund and sectoral lending from the World Bank.

\section{Structure of the economy}

Jordan is a lower/middle-income country of an estimated 4 million inhabitants with an annual per caplta incone estinated at US\$1,370 in 1994. Its economic structure is dominated by trade- and service-related activities (including government services). These account for more than two thirds of GDP at factor costs (Chart 1); manufacturing, agriculture, mining, and construction account for the rest. Construction has been the driving force in periods of strong economic growth. Because of its very narrow production base, the economy is highly dependent on imports, which represent more than 60 percent of GDP. Workers' remittances from the neighboring oil-rich countries and processed mining-based exports are the primary sources of Jordan's foreign exchange earnings.

The size of the public sector in Jordan is large in relation to the level of domestic economic activity. However, the public sector is not engaged in manufacturing activities; its involvenent is primarily limited to the provision of basic services (health and education), public utilities (water and electricity) and of infrastructural support, mainly in the areas of transport, communications, and irrigation. Central government expenditures account for about 35 percent of GDP, although at about 30 percent of GDP the total revenue to GDP ratio is also high in comparison with other non-oil middle-incone countries.

The quality of services provided by the public sector in Jordan is generally good and social indicators are satisfactory. Literacy and enrollment rates at primary and secondary school levels are high, and nutrition and health conditions are generally satisfactory.

Prudent expenditure programs, combined with the avallability of foreign grants and the regional economic boom assoclated with a sharp rise in oil prices, I led to economic prosperity in Jordan during the 1970 s and the first half of the 1980s. Subsequently, however, as the regional economies entered into a recessionary period in the wake of falling petroleum prices by the mid-1980s, Jordan's underlying financial imbalances came to the forefront. By 1987-88, these imbalances had become unsustainable and led to a severe balance of payments crisis that seriously undermined the economy's growth prospects. These problems were compounded by the adverse effects of the August 1990 regional crisis.

1 These also provided markets for exports of goods and services. 


\section{Origins of Jordan's economic difficulties in the 1980 s}

\section{a. Broad stratery durine the 1970s-mid-1980s}

Since the early 1970s, Jordan's strategy was to develop itself as a provider of skilled manpower and trade-related services to the Arab countries in the region. Accordingly, the authorities chose a strategy aimed at having the growing number of educated youths in a position to seek employment around the region. At the same time, with the sizable amounts of remittances and aid received from abroad, Jordan was able to maintain income and consumption at levels that exceeded those that could be expected from the avallable production capacity in the domestic economy.

\section{b. Macroeconomic outcone: an oyerview}

Jordan's economic growth during the 1970 s and through the mid-1980s was robust. Domestic prices were generally stable, reflecting in part prudent monetary policy (Chart 2). $W$ As a result of high recurrent expenditures, large fiscal deficits were incurred (Charts 3 and 4 ), 2 ( but these were largely financed by readily available foreign grants. Fiscal revenues remained highly dependent on international trade-based taxes, even though the revenue to GDP ratio incressed to 25 percent of GDP by the mid-1980s. The domestic savings rate was relatively high. Investment remained at comfortable levels (at more than 20 percent of GDP), but much of the domestic private sector investment was directed to housing construction. Despite an unusual import boom. the external current account remained in virtual balance during this period (Chart 5). However, because of inappropriate incentives and price signals, efficient import-competing and export-orlented domestic manufacturing activities could not develop. Moreover, by the mid-1980s, the flow of foreign grants from traditional regional countries and inflows of workers' remlttances started to decline in the aftermath of the ofl price collapse. The authorities responded to these developments by: (1) turning to external commercial and domestic bank borrowing to finance budgetary deficits, $3 /$ and unsustainable levels of domestic aggregate demand; and (ii) maintaining domestic price stablilty through control of administered prices. As a result, there was a rapid acceleration of external debt service burden, which led to the emergence of serious domestic financial imbalances. Moreover, the sharply higher public sector debt service payments further accentuated Jordan's medium-term fiscal imbalance. Reflecting a relatively easy credit stance and the effect of

1 The average rate of inflation was contained at around 5 percent during the decade through the mid-1980s.

2 These, excluding foreign grants, averaged more than 20 percent of GDP during the period through the mid-1980s.

3 During 1986-88, claims on the Central Government increased by more than 300 percent. 

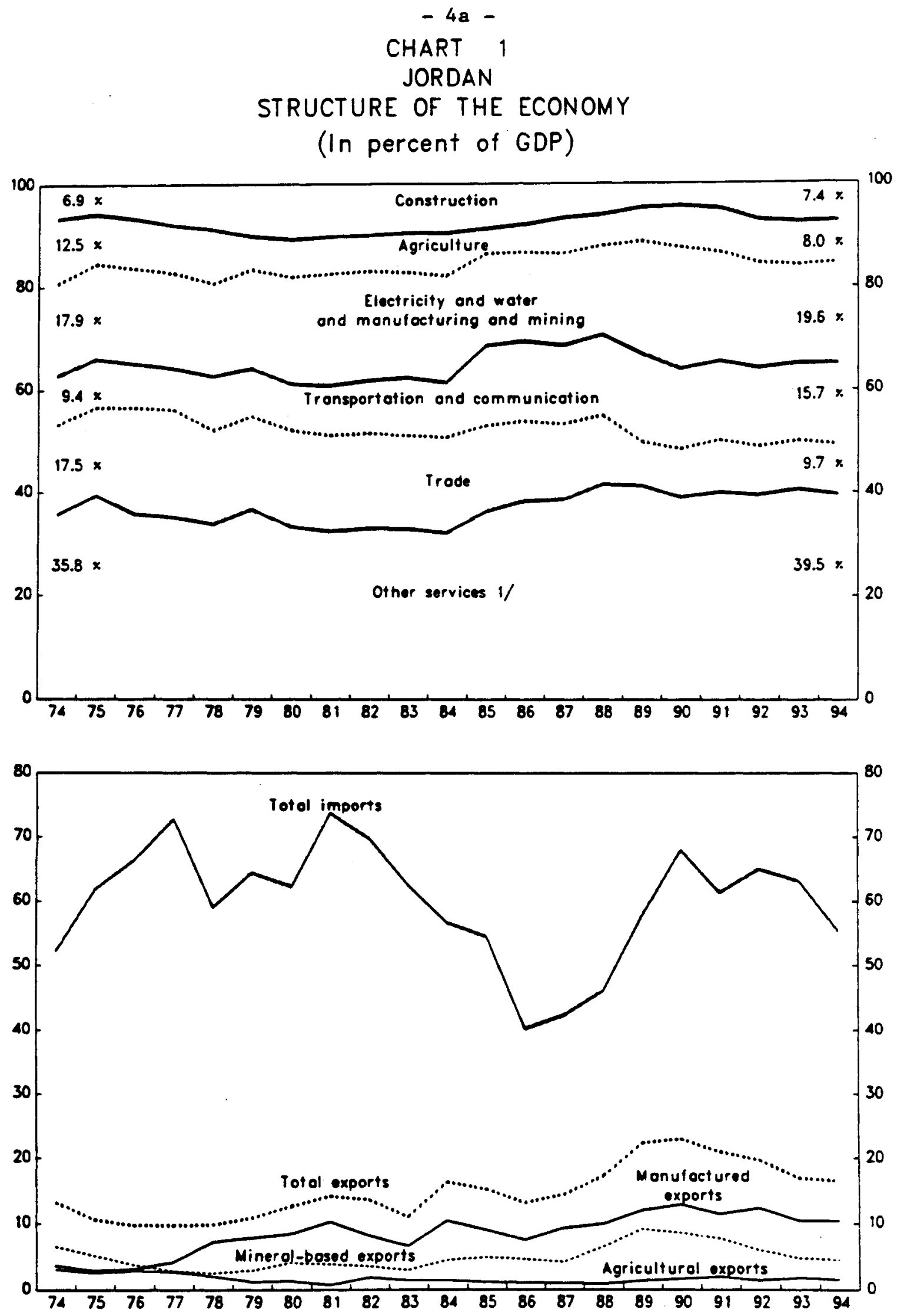

Sources: IMF. International Financial Statistics, and various Recent Economic Development Reports. 1/ Including government services. 


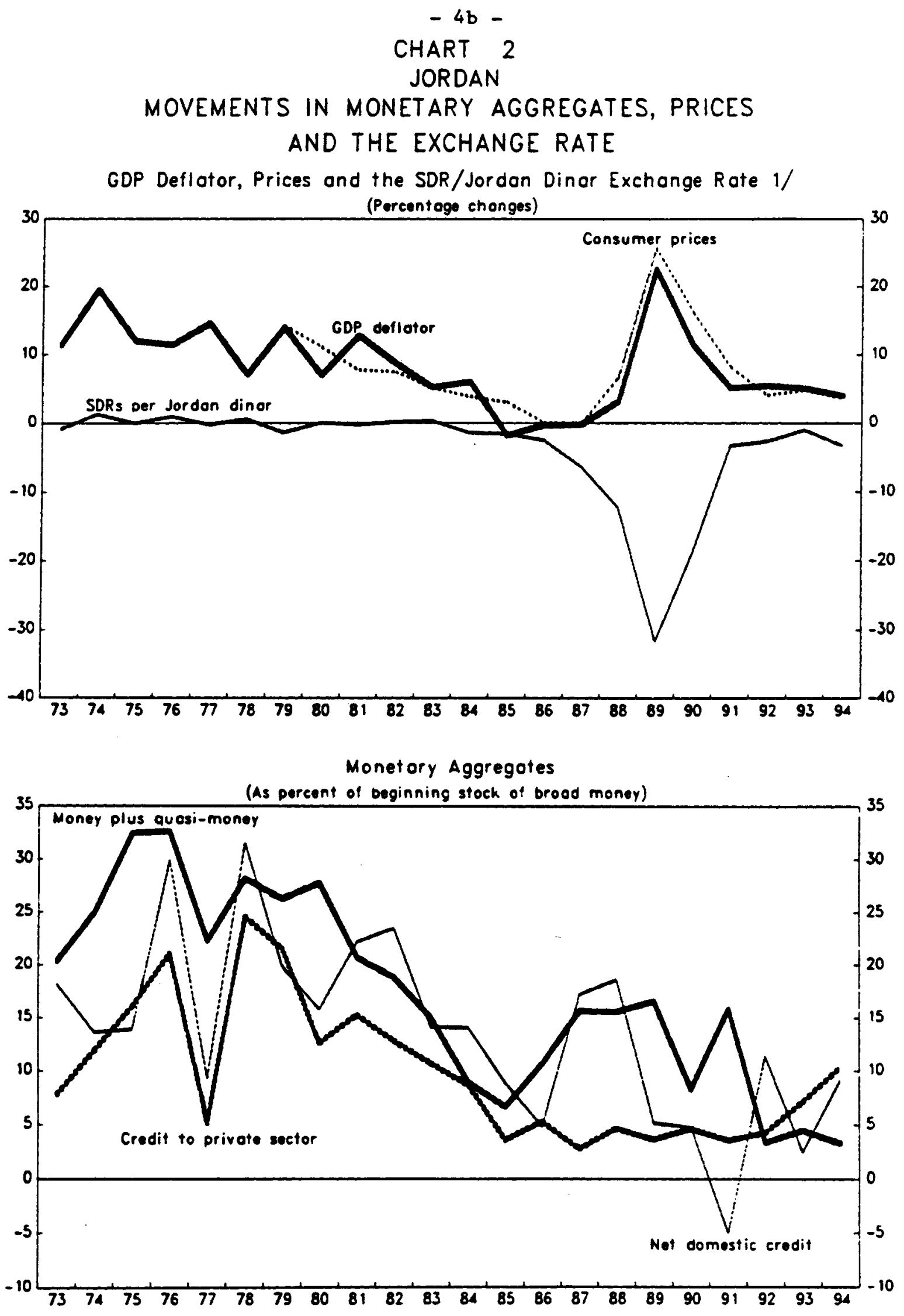

Sources: IMF. Internotional Finoncial Statistics, and vorious Recent Economic Development Reports. 


\section{CHART 3 \\ JORDAN \\ CENTRAL GOVERNMENT OPERATIONS}

(In percent of GDP)

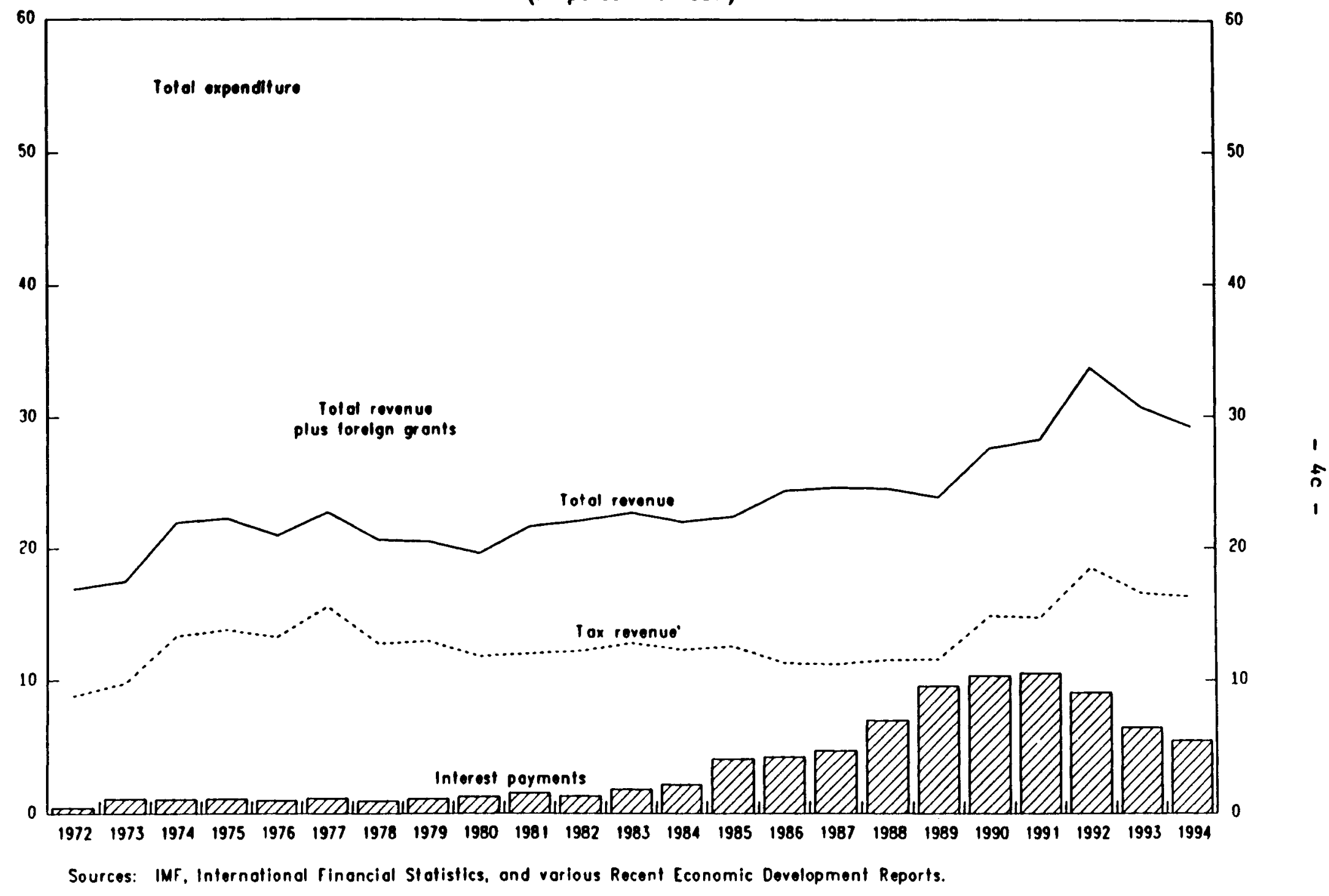

CInternational Monetary Fund. Not for Redistribution 
CENTRAL GOVERNMENT OPERATIONS

(In percent of GDP)
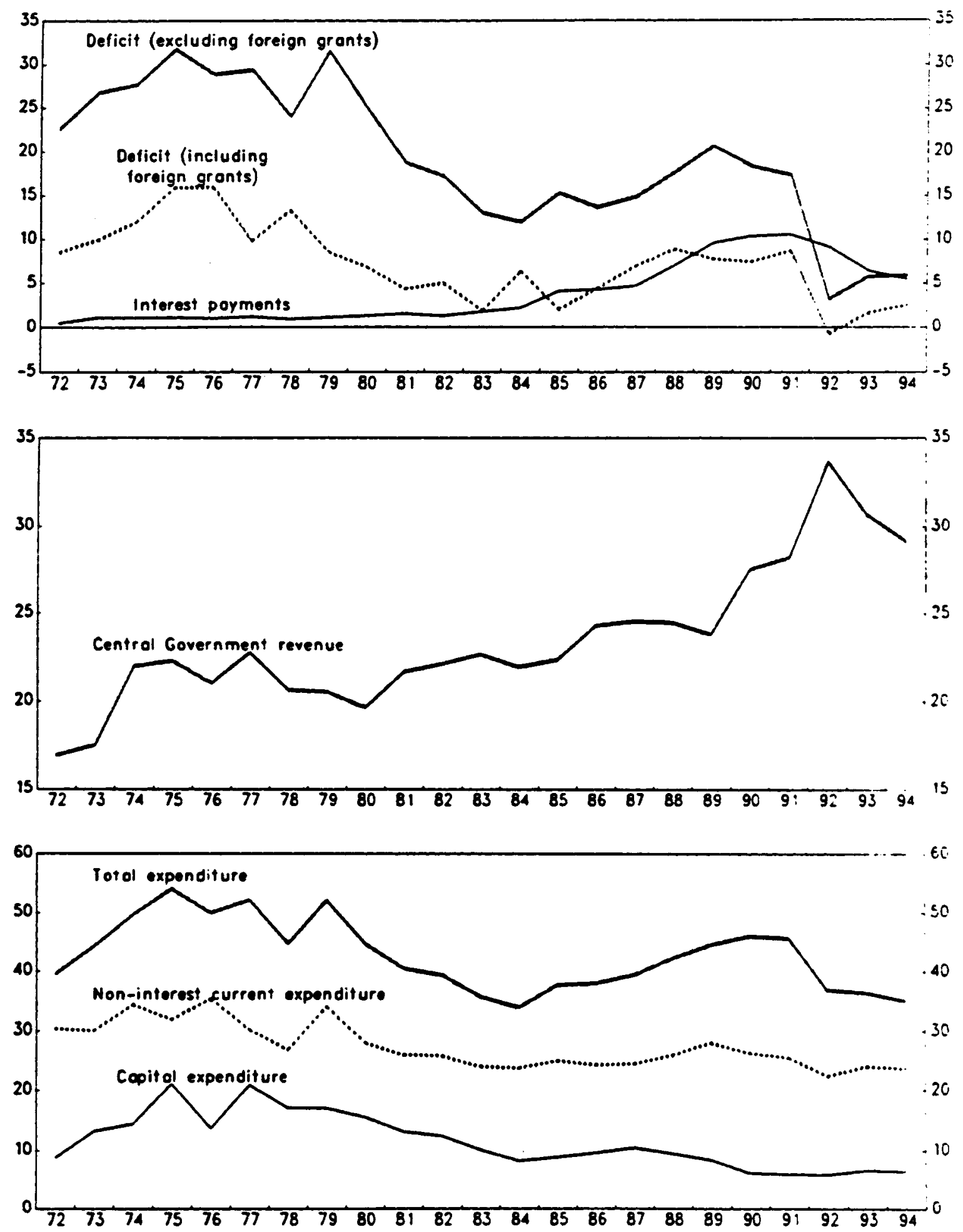

Sources: IMF. Internotional Financial Statistics, and vorious Recent Economic Development Reports. 
CHART 5

JORDAN

EXTERNAL SECTOR

(In percent of GDP)

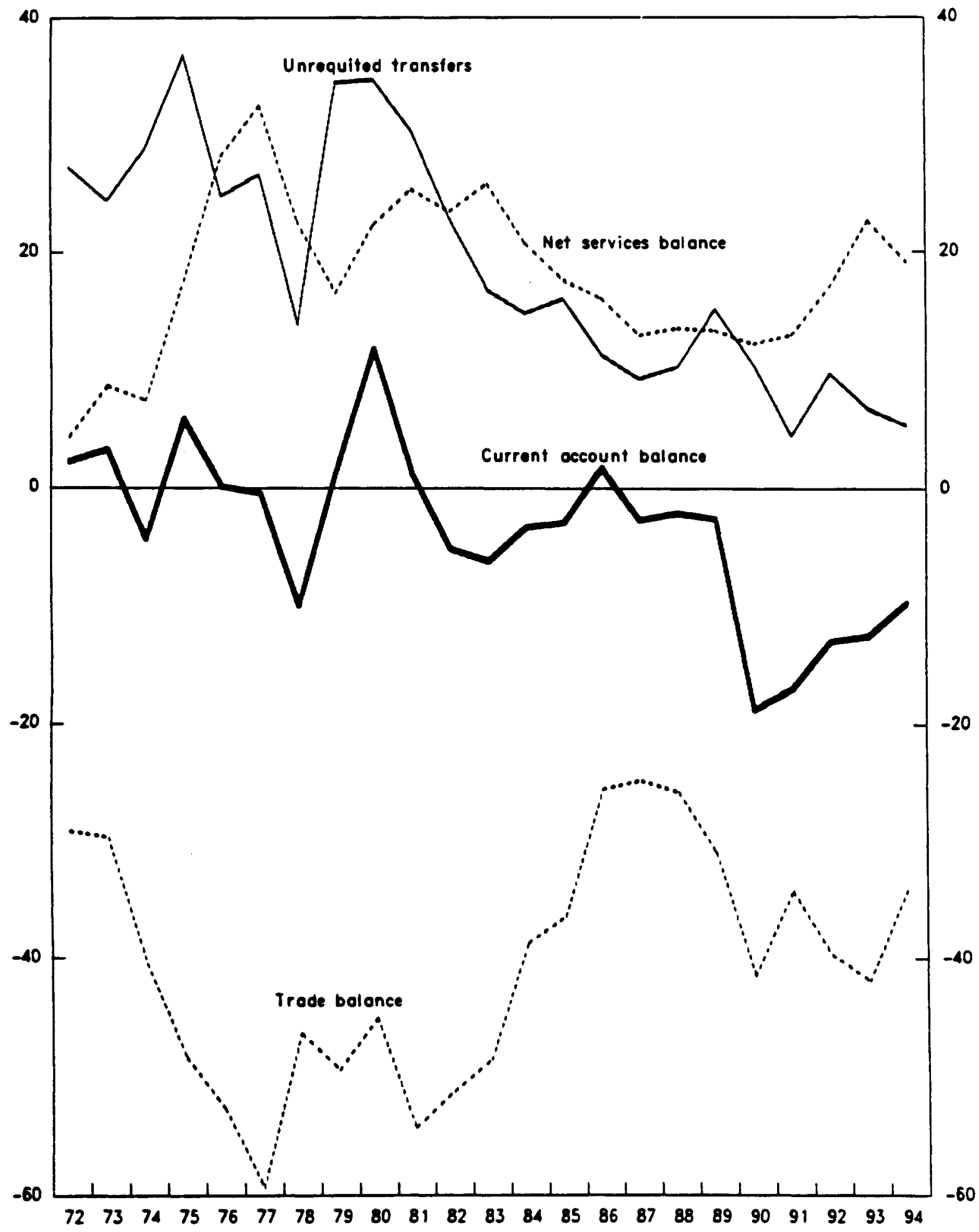

Sources: IMF. Internotional Financial Statistics, and various Recent Economic Development Reports. 
This page intentionally left blank 
large devaluations, by 1988 inflation started to accelerate. $1 /$ At this time, commercial banks started to accumulate nonperforming assets, leading to bank fallures by the late 1980s.

Access to external borrowing virtually ceased to exist by 1988 , and the authorities decided to initiate corrective macroecononic policies, including a large devaluation of the Jordan dinar (Chart 6 ). $2 /$ By that time, however, Jordan had become one of the most heavily indebted countries in the world, with external debt to GDP ratio increasing to 193 percent of GDP by 1990 (Chart 7).

\section{c. Structural weaknesses}

In addition to the linited resource base, Jordan's economic performance was also handicapped by policy-induced structural weaknesses in various sectors. The tax system in Jordan--although effective in mobilizing resources for government operations--suffered from inefficiencies resulting from cascading. widespread exemptions, multiplicity of taxes and tax rates, and inefficient tax administration. On the expenditure side, high military expenditure, extensive subsidy programs, $3 /$ and a growing external debt service burden complicated efforts to reduce the fiscal deficit to a sustainable level. Jordan's trade regine was characterized, until the late 1980s, by notionally high and conplex tariff structure, nontariff barriers, widespread exemptions, and institutional inadequacies which adversely affected 1 ts export and industrial sector performance. 4

In the agriculture sector, subsidized water and domestic producer price support contributed to the inefficient use of scarce water resources, while production controls on ajor vegetable crops prevented higher production and

1 The rate of inflation accelerated to double digit levels, averaging 14 percent during 1988-90; beginning in 1988, all deposit and lending rates became negative in real teras.

2/ The exchange rate, which had reanined fixed to the SDR over more than 20 years through the and of 1987, was depreciated by 21 percent in real effective terns in 1988.

3 These covered in particular basic foods, energy, agricultural production and inputs, and transportation.

4) The maximum tariff rate was 318 percent while, owing to widespread exemptions, the bulk of imports was imported duty free. Nearly 30 institutions accounting for 51 percent of imports into Jordan were exempt from paying any import duty. Nontariff barriers in the form of quantitative restrictions were also widespread; about 40 percent of imports were subject to quantitative restrictions in 1988. Combined with these nontariff barriers, the high degree of variations in the tariff rates (between 0 and 318 percent, with standard deviation of 26.1) led to a high degree of variation in effective rates of protection. 
export of high value horticultural products $\mathcal{W}$ (where Jordan appeared to have some comparative advantage). The energy sector also suffered from inadequate pricing policies for petroleum products and electricity, insticutional inefficiency in the associated public sector enterprises, and the limited role of the private sector in energy sector development projects. 2/ As regards the financial sector, $3 /$ avallability of financial instruments was limited, and instruments for indirect control had not been developed. $4 /$

\section{Adiustment and structural reform efforts $1989-94$}

To address the rapidly growing imbalances, In early 1989 the Government adopted a medium-term growth-oriented adjustment program supported by the Fund and World Bank, which resulted in some initial progress toward the reduction of macroeconomic imbalances and introduction of some structural reforms. However, following the August 1990 regional crisis, real income was reduced, unemployment rose sharply--as a result of the reflux of Jordanians working in the neighboring countries-.trade was disrupted, and aid flows from the countries in the region ceased. These adverse developments rendered the attainment of the program targets impossible.

In 1991, the authorities sought to re-evaluate their adjustment and reform effort. This led to the adoption of second medium-term adjustment program beginning in 1992, supported by the Fund and the World Bank.

\section{a. Performance under the 1989.90 adjustment program}

Jordan's economic and financial performance under the SBA in 1989 was encouraging. All the policy actions contemplated in the program were implemented which, In combination with debt relief and bilateral grants by donors, enabled Jordan to meet all the quantitative performance criteria in 1989. The expansion in the net domestic assets of the banking system. the trade deficit, and the external current account deficit were kept below their respective program targets, allowing the Central Bank of

1 For more detalls on structural issues related to Jordan's agriculture sector, see Jordan: Towards an Aericulture Sector Strategy, World Bank Report No. 7547-50 (June 1990).

2/ For more detalls on structural issues related to Jordan's energy sector, see Jordan: Energy Sector Study. World Bank Report No. 7984-JO; Vol. I and II; (February 1990).

3) Four main, direct-type monetary instruments were used: banks' reserve requirements, liquidity ratio, credit guidelines, and interest rate ceilings, with legal reserve ratios being kept low (effectively in the range of $7-8$ percent of local currency deposits) during most of the period through 1987 .

4 Reserve ratios started to be more actively used beginning in 1988 only, to absorb excess liquidity of the banking system generated in part by rapidly increasing bank borrowing by the Government. 


\section{CHART 6 \\ JORDAN}

EXCHANGE RATE INDICES, 1988-95

$(1980=100)$

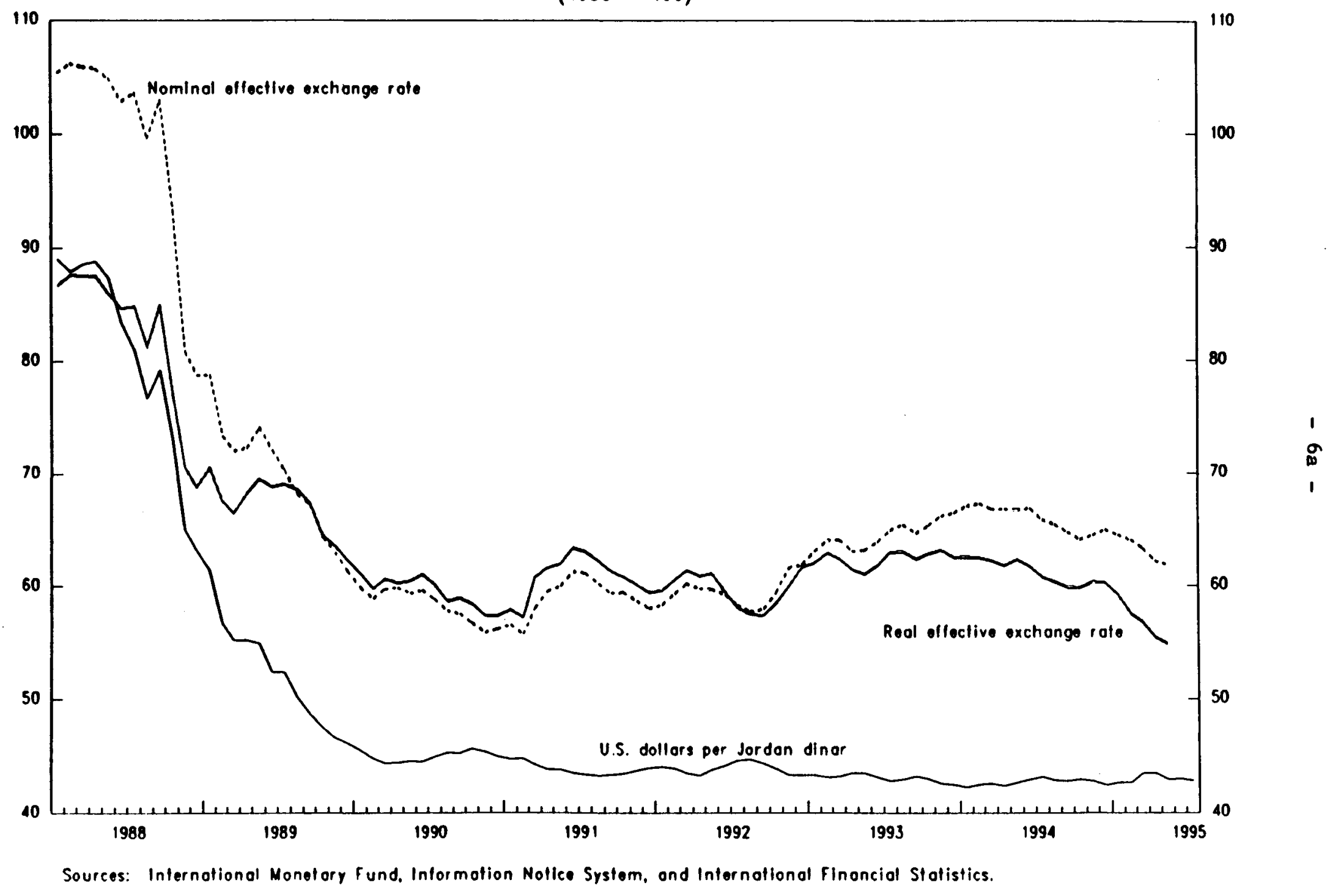

CInternational Monetary Fund. Not for Redistribution 
$-6 b-$

CHART 7

JORDAN

EXTERNAL DEBT AND DEBT SERVICE, 1990-2000

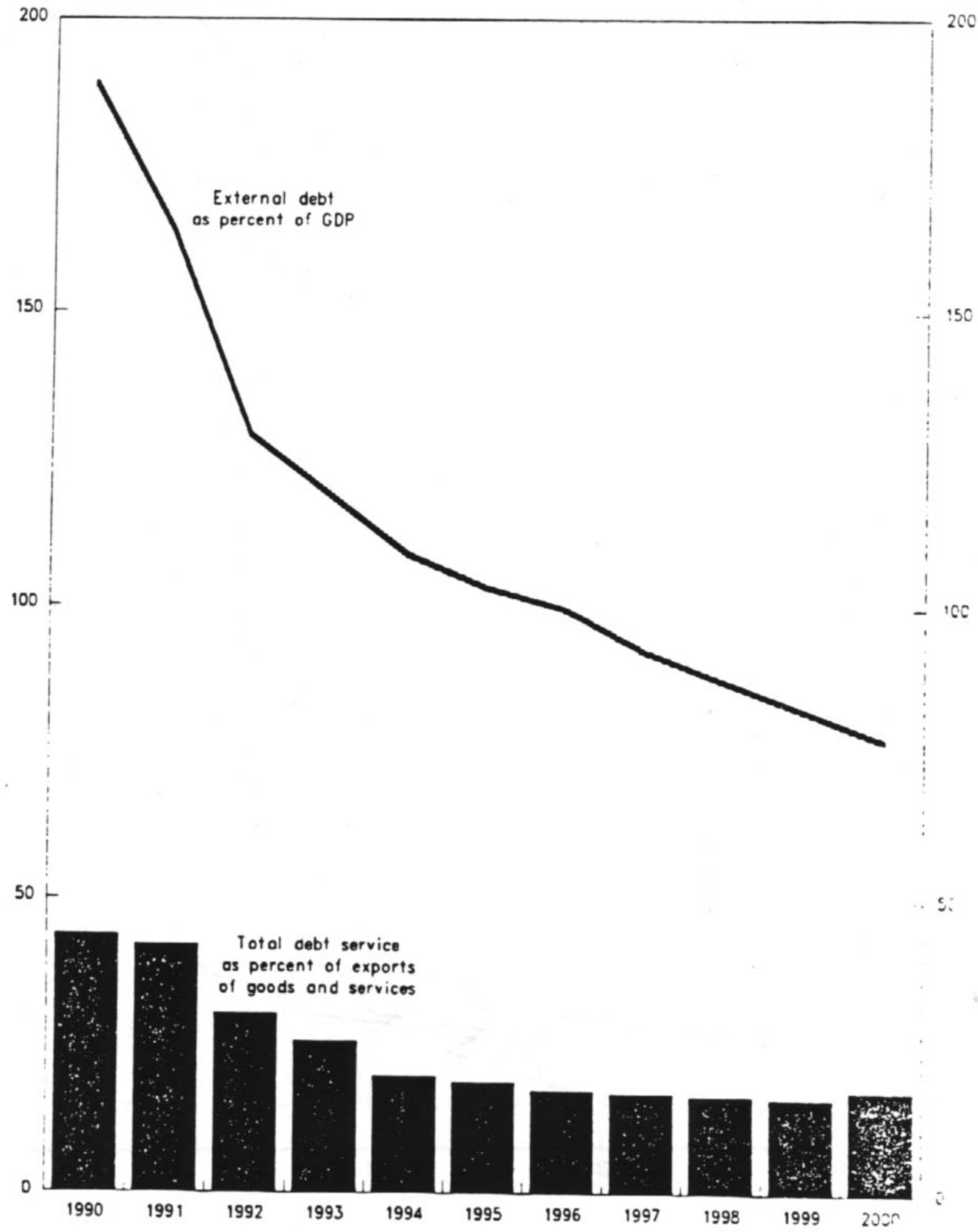

Sources: Doto provided by the Jordan authorities. 
Jordan's (CBJ) foreign exchange reserves to exceed significantly the program target in 1989. The budgetary situation also improved, although due to higher than expected interest payments, the overall budget deficit exceeded the program target.

On the structural front, following the exchange rate depreciation in 1988, a number of reforns were introduced in the exchange and trade systems and interest rate policy under the 1989.90 program. These included, in particular, abandonment of the dual exchange rate system $1 /$ and unification of the official and interbank rates at the level of the more depreclated interbank rate; $2 /$ adoption of a flexible exchange rate management, with the Jordan dinar pegged to a basket of currencies; abandonment of the pollcy of supporting the interbank rate through intervention; freeing up interest rates; 3 and phasing out nontariff barriers in stages and replacing these by tariffs initially, and by reducing tariff barriers as a whole subsequently, to lower effective protection and foster a broadly neutral system of incentives. 4

The Government also adopted a debt nanagement strategy aimed at obtaining debt rellef through the rescheduling and lengthening of the maturity structure of debt and reducing the debt burden in relation to GDP in a medium-term context (see Section VI for more details). Consistent with these objectives, the Government: (1) concluded a restructuring agreement with the Paris Club in July 1989 and regularized relations with other official bilateral creditors along terms similar to those obtained from the Paris Club; (11) Initiated negotlations with the commerclal banks to obtain a multi-year restructuring of obligations falling due to banks with provisions for new noney and options for debt conversion; (iii) limited all new borrowings to longer term maturities and, in many instances, at

1) Which had been introduced as a temporary emergency measure in July 1989 to address acute balance of payment difficulties.

2) The unification led to further nominal effective depreciation of 8.5 percent.

3/ Both deposit and lending interest rates were allowed to be freely determined by market forces.

4) In August 1988, 30 categories of products had their import bans removed and replaced with tariff protection. The percentage of imports subject to quantitative restrictions (QRs) was reduced from 40 percent in early 1988 to less than 7 percent in 1990. Import prohibition on 11 consumer luxury Items, which were banned on a time-bound basis for balance of payments reasons, was eliminated in January 1990 . For the remaining 93 percent of the items subject to tariff, the range between the maximum and minimum tariffs was reduced to 55 percent at a first stage, by lowering the maximum tariff rate to 60 percent and increasing the minimum tariff rate to 5 percent. This narrowing of the range reduced the variation in tariff (measured in terms of standard deviation) to 17.5 in $1990 \mathrm{from}$ 26.1 in 1988 . 
concessional interest rates; $\mathcal{V}$ and (IV) canceled most new commercial borrowings which were in the pipeline, including in particular a military aircraft purchase agreement. $2 /$

Adjustment policies were continued in 1990 when the authorities implemented various structural measures, including tariff reforms and further interest rate liberalization, and pursued flexible interest and exchange rate policies. However, a number of adverse developments during 1990, including, in particular, the regional crisis, pushed the economy off track.

\section{b. Performance under the 1992-94 adjustment and reform proaram}

The broad objectives of the 1992.94 programs-.supported by a second stand-by arrangement and subsequently by the ongoing extended arrangement-. were to: (i) achieve a significant reduction in the macroeconomic imbalances; (ii) continue the process of structural reform, despite considerable uncertainties about trade and aid relations between Jordan and its neighboring countries; and (11i) achieve balance of payments viability by 1998 while attaining satisfactory growth performance in the context of stable domestic prices with an increased role of the private sector in the economy.

The key policy elements of the program were to: (1) reduce the fiscal deficit substantially, through revenue enhancements and containment of current expenditures: (11) contain credit expansion consistent with the external and inflation objectives and with achieving interest rates that were positive in real terms: (111) continue a flexible exchange rate management, with view to ensuring competitiveness of exports; (iv) carry forward the process of structural reforms inltiated in 1989, particularly the second phase of tariff reform and the reform of the indirect tax system through the introduction of general sales tax (CST): and ( $v$ ) prepare a plan of action for reform of the agriculture and water and energy sectors for implementation over 1992-94.

\section{(1) Macroeconomic stabilization and outcome}

Jordan's macroeconomic performance under the program during 1992-94 has been solid. The economy's real growth, inflation, and fiscal adjustment performance have been much better than anticipated at the inception of the program; and despite a surge in imports essociated with the large influx of returnees, the balance of payments adjustment has been stronger than targeted. After several years of decline or virtual

1) Along these Iines, the Government also converted all short-terw debt to medium-term maturities and did not incur new short-term or nonconcessional debt in the $1-12$ year maturity range.

2) This latter action alone reduced the debt burden by US\$l billion (25 percent of GDP). 
stagnation, econonic activity gained monentum in 1992. Real GDP growth (at market prices) exceeded 16 percent in 1992, $\mathcal{V}$ against a program target of 3 percent, and growth averaged about 6 percent annually during 1993-94. This turnaround is largely attributable to strong activity in construction, but was also facilitated by a solid recovery in the agriculture, trade, and manufacturing sectors. Favorable supply response and import prices, coupled with prudent denand-managenent policles, contributed to a sharp deceleration of inflation to 4-5 percent range during this period, much below the program targets. The unemployment rate declined to the $12-15$ percent range during 1993-94 from a peak of 25 percent in 1990, despite high labor force growth.

The overall fiscal deficit (excluding foreign grants) declined from 17.8 percent of GDP in 1991 to 3.7 percent of GDP in 1992, including the impact of nonrecurrent revenue sources (estinated at 3.5 percent of GDP); this compares with the program target of 13.7 percent of GDP. This sharp reduction in the flscal deficit reflected the effect of discretionary fiscal measures (2.5 percent of GDP) adopted in the context of the 1992 budget. strict expenditure control, and buoyant revenue collection, including nonrecurring revenues ( 3.5 percent of GDP). Excluding the effect of nonrecurring revenues, the underlying fiscal deficit is estimated to have declined to about 7 percent of GDP. The authorities' fiscal policy stance has been further tightened during 1993-94, as the underlying fiscal deficit (excluding nonrecurring factors) declined further to less than 6 percent of GDP in 1994, reflecting the effect of discretionary measures and strong economic growth.

The favorable fiscal outturn and cautious credit policy stance contained the growth of the net domestic assets (NDA) of the banking system to 7.6 percent in 1992 , below the program target of 8.5 percent. 2/ Supported by the improved fiscal position, monetary expansion remained well below the increase in nominal GDP since 1992.

The external current account deficit declined to 14.4 percent of GDP (excluding workers' savings and grants from the Gulf Crisis Financial Coordination Group (GCFCG)) in 1992, despite much higher than programmed imports associated with the economic expansion. The deficit declined further by 3 percentage points to 11.6 percent of GDP in 1993 and thereafter by a further 5 percentage points to 6.5 percent of GDP in 1994 . This outcome was attributable to the continuing strong performance of remittances, nontraditional exports, and a strong recovery of tourism receipts. Higher-than-programmed recelpts on account of these latter factors largely offset the shortfall in traditional mineral-based exports arising from shipping problems for phosphate rocks, the loss of markets, and collapse in world market prices, and, in addition in 1992, the substantially higher-than-programmed growth of imports associated with buoyant economic

1 Real GDP growth at factor costs was 12.1 percent in 1992.

2 For more details on monetary developments and the corrective measures, see Section V. 
activity. Nontraditional exports were strong throughout the period. 1 With these developments and larger-than anticipated transfers of workers' savings, $2 /$ the overall balance of payments deficits were below the program targets in both 1992 and 1993, with the CBJ's foreign exchange reserves exceeding the program targets in both years. Rescheduling of debt service and overdue obligations to the Par1s Club creditors in February 1992 and recelpts of exceptional assistance from the GCFCG significantly contributed to the balance of payments financing during 1992-93. However, reflecting the effect of regional uncertainties resulting from the peace process and the potential redenption of Jordan dinars (JDs) circulating in the West Bank, the level of gross officlal forelgn exchange reserves of the CBJ declined sharply in the first half of 1994. The level of reserves improved signiflcantly in the second half of 1994, In response to a substantial tightening of the stance of monetary policy; but by year's end. it only amounted to the equivalent of about 5 weeks of imports.

Significant progress was also made in normalizing payments relations with external creditors and in reducing outstanding payments arrears. In addition, progress was made in liberalizing the exchange system; in particular, the amount of foreign exchange that can be transferred abroad by residents and nonresidents annually has been increased to JD 35,000 (equivalent to US\$50,000), $3 /$ and the CBJ abolished the regulation under which export proceeds were to be repatriated within a specified period. Jordan achieved the current account convertiblilty and accepted obligations of Article VIII Sections 2, 3, and 4 in February 1995.

\section{(2) Structurel reforms}

On the structural front, the second phase of the tariff reform was concluded in early 1992, with a further reduction of the maximum tariff rate (by 10 percentage points) to 50 percent (except for few luxury items) and a further decline in the standard deviation of the tariff rates to 15.9 percent. In the real sector, control of cropping patterns was abolished as part of the reform effort supported by the World Bank Agriculture Sector Adjustment Loan (ASAL), and the axle load regulation was being implemented in the context of the World Bank's Third Transport Project. Following the implementation of necessary prior actions, including substantial increases in electricity and selected petroleum prices, the World Bank Executive Board approved an Energy Sector Adjustment Loan (ESAL)

1 Rising by at an annual average rate of 14 percent in dollar terms over the period 1989-94.

2. Primarlly repatriation of foreign financial assets of Jordanians who had previously worked abroad.

3 An additional JD 20,000 is avallable for medical expenses, JD 20,000 for family support, and a further JD 5,000 can be taken out in Jordanian bank notes. 
in October 1993. In September 1993, the authorities also started to issue central bank JD-denominated certificates of deposits, as a new Indirect instrument of monetary control.

In order to broaden the donestic tax base and improve elasticity and efficiency of the tax system, the Goverment replaced the consumption tax system by a GST with Input tax credit nechanism to renove cascading of taxes at different stages of production in June 1994. Various elements of the Government's reform program has been discussed in detall in other chapters as appropriate.

\section{Overall assessment}

Following a mixed performance under the authorities' 1989-90 stabilization program--largely attributable to the 1990 regional crisis--renarkable progress was made on the macroeconomic front during 1992-94. Sustained fiscal and external adjustments, coupled with prudent exchange rate and debt management, have contributed to a stable macroeconomic environment conducive to sustained economic growth with price stability. The financial support provided by the GCFCG and from other multilateral and bilateral creditors and the favorable effect of the unexpectedly large transfers of workers' savings were also instrumental in easing the adjustment process. While the economy has responded very well to the implementation of adjustment and reform policies implemented in recent years, Jordan's extermal position still remsins weak and vulnerable, especially in light of the persisting, large external debt overhang. The Government is continuing with ambitious adjustment and broad based reform strategy under the extended arrangement. The program supported under the arrangement is comprehensive and it constitutes a decisive move toward addressing the medium-term difficulties facing the Jordanian economy.

\section{Macroeconomic Environment, Growth and Investment}

This section provides background information on how Jordan's adjustment and reform programs and the resulting improved macroeconomic policy environnent have influenced investwent and growth in recent years. Since the source of growth and investment cones mostly from the private sector, it is usually thought that effects of the ancroeconomic policy environment on growth and investient work via changing perceptions of confidence and uncertainty. Uncertainty about the macroeconomic policy environment tends to reduce the rate of growth and investment as investors have an incentive to wait until the uncertainty has been resolved before committing themselves to an irreversible course of action. Internal and external imbalances and high Inflation rates generate uncertainty because they encourage a perception that a government is losing or has lost control over its economy, and that a remedial course of action is called for. Especially, since the nature and timing of changes in macroeconomic policy are unknown to private investors, they would tend to postpone investment decisions. 
The basic indicators of the macroeconomic environment that are employed to examine the potential effect of adjustment programs on investment and growth are the inflation rate, the fiscal balance, and the external current account balance. Movements in the terms of the trade, inflow of workers remittances, and changes in the real exchange rate are basic indicators of external shocks affecting growth and investnent. Based on the empirical analysis presented in this section and drawing on inferences from other empirical works, this paper concludes that: (i) real GDP growth is attributable more to increases in physical capital rather than increases in the labor force; (1i) despite impressive growth performance, total factor productivity has declined in recent years due to the need to absorb some 300,000 Jordanian from abroad into the economy; (1ii) the most significant policy impact on real GDP growth has been through fiscal policy; accordingly, the negative impact of high fiscal deficits of the past has been declining with the progress made in reducing the deficit, despite falling grants; (iv) the major channel by which fiscal policy has affected real GDP growth is through slowing down the rate of capital accumulation by the private sector; and $(v)$ the most important determinant of private investment in Jordan is the inflow of extermal financing in the form of workers' remittances and transfer of savings.

The remainder of this chapter is outlined as follows. Section 1 gives a brief overview of economic developments in Jordan over the period 1976-94 divided into four sub-periods, based on general macroeconomic environment and performance in terms of investment and growth. I Section 2 examines the factors influencing economic growth. In particular, the contribution to economic growth by factors of production are analyzed together with an analysis of how growth is influenced by the macroeconomic policy environment. Section 3 examines the factors influencing private investment.

1 The four episodes measured in terms of real GDP growth performance: (i) the boom of the 1970s; (11) the slowdown of the early 1980s; (i1i) the slump of the late 1980s; and (Iv) the recovery of the early 1990s. This four stage development highlights the initial boom (In the 1970s) leading to emergence of underlying imbalances in early 1980 s as regional economies went into recession. Peralstent macroeconomic imbalances, in the form of large fiscal and balance of payments deficlts led to mounting debt and debt service problems. The resulting balance of payments crisis in the second half of 1980 s set the stage for a fundamental shift in the Government's macroeconomic policy stance. The adjustment and structural reforms initiated since 1989 have significantly reduced Jordan's macroeconomic imbalance and led to a sustained recovery in economic activity since early 1990s. 


\section{Economic developments over the period 1976-94}

\section{a. The boom of the 1970s}

Over the period 1976 to 1980, real GDP rose by 9.5 percent per year and investment was 35 percent of GDP (Table 1). During this period, much of the domestic private sector investment was directed to housing construction and partly to transport and mineral-based processing sectors; and therefore, such investments had IImited direct impact on the future growth potential of the economy. During this period, Jordan's growth and investment depended heavily on external financing. Private construction activity was largely financed through workers' remittances, while grants and loans from oilexporting countries in the region accounted for a large part of the financing for Jordan's public sector investment.

The indicators of macroeconomic policy reflect a mixed situation over the period 1976 to 1980: inflation averaged 11.7 percent; the average fiscal deficit of the central government (excluding foreign grants) was 29 percent of GDP; but the external current account--reflecting receipts of sizable foreign grants--remained virtually in balance (averaging 0.2 percent of GDP). The large budget deficits were a result of the Government's efforts to improve public utilities and services, together with higher defense expenditure and subsidies for specific basic goods.

b. The slowdown of the early $1980 \mathrm{~s}$

By the early 1980s, the terms of trade deterlorated, resulting in the subsequent deterioration in the external current account balance to a defictt of 5.2 percent of GDP. Furthermore, as oil prices and revenues started to decline, the level of external aid (primarily from regional oil producing countries) as a share of GDP dropped from 16.6 percent to 10 percent, which in turn led to a reduction in public sector investment as a share of GDP from 18.9 percent to 13.9 percent (Table 2). While public sector investment bore the brunt of the shock, private sector investment remained steady, at approximately 16 percent of GDP. The decline in investment and inflow of workers' remittances adversely affected the economy with real GDP growth falling to an average of 6.2 percent over the period 1981-85. The fiscal deficit (excluding foreign grants) declined by more than 10 percentage points, although it remained very high at 18.5 percent of GDP; the reduction in fiscal deficit was largely attributable to cuts in development expenditure. Inflation was contained to an average annual rate of 4.1 percent by maintaining stable nominal exchange rates and due to a moderation in the world rate of inflation.

\section{c. The balance of payments crisis and economic slump} in the late 1980 s

In the second half of the 1980 s, debt service obligations and fiscal imbalance increased sharply. Jordan's debt service was 45.4 percent of exports of goods and services in 1989, while the average fiscal deficit 
Table 1. Jordan: Macroeconomic Performance, 1976-94

\begin{tabular}{|c|c|c|c|c|c|c|c|c|}
\hline \multirow[b]{2}{*}{ Period } & \multirow[b]{2}{*}{$\begin{array}{l}\text { Real GDP } \\
\text { Growh } y\end{array}$} & \multirow[b]{2}{*}{$\begin{array}{l}\text { Gross Fised } \\
\text { Investment } y\end{array}$} & \multirow[b]{2}{*}{$\begin{array}{c}\text { Inflation } \\
\text { Rate } y\end{array}$} & \multicolumn{2}{|c|}{ Fiscal Batance $\boldsymbol{u}$} & \multirow{2}{*}{$\begin{array}{l}\text { Current } \\
\text { Acoount } \\
\text { Balance } \mathbf{Y}\end{array}$} & \multirow{2}{*}{$\begin{array}{c}\text { Terms of } \\
\text { Trade } 1 / \\
(1992=100)\end{array}$} & \multirow{2}{*}{$\begin{array}{c}\text { Real Exchange } \\
\text { Rale } 1 / \\
(1992=100)\end{array}$} \\
\hline & & & & $\begin{array}{r}\text { Excluding } \\
\text { Grants }\end{array}$ & $\begin{array}{r}\text { Including } \\
\text { Grants }\end{array}$ & & & \\
\hline $1976-80$ & 9.5 & 35.0 & 11.7 & -29.0 & -12.4 & 0.2 & 85.3 & 171.4 \\
\hline $1981-85$ & 6.2 & 31.0 & 5.4 & -18.5 & -8.5 & -5.2 & 80.1 & 1427 \\
\hline $1986-90$ & -0.9 & 223 & 9.7 & -20.1 & -12.8 & -3.3 & 91.9 & 117.3 \\
\hline $1991-94$ & 7.4 & 28.7 & 4.8 & -10.8 & -6.0 & -12.5 & 98.8 & 99.9 \\
\hline $1976-94$ & 5.4 & 27.7 & 7.8 & -20.0 & -10.1 & -4.8 & 87.8 & 135.6 \\
\hline
\end{tabular}

Sources: Department of Statistics, Government of Jordan; Central Bank of Jordan; and staff estimates.

y Period average.

2I In percent of GDP.

3/ In percent of GDP, excluding foreign grants. 
Table 2. External Financing and Investment, 1976-94

(In percent of GDP)

\begin{tabular}{lcccc}
\hline Period & $\begin{array}{c}\text { Private } \\
\text { Investment 1/ }\end{array}$ & $\begin{array}{c}\text { Central } \\
\text { Workers' } \\
\text { Remittances }\end{array}$ & $\begin{array}{c}\text { Government } \\
\text { Capital } \\
\text { Expenditure }\end{array}$ & $\begin{array}{c}\text { Central } \\
\text { Government } \\
\text { External Aid }\end{array}$ \\
\hline $1976-80$ & 16.0 & 20.7 & 18.9 & 16.6 \\
$1981-85$ & 16.2 & 22.3 & 13.9 & 10.0 \\
$1986-90$ & 7.1 & 14.2 & 15.3 & 7.3 \\
$1991-93$ & 16.3 & 16.3 & 13.1 & 4.8 \\
$1976-94$ & 13.7 & 18.5 & 15.4 & 9.9 \\
\hline
\end{tabular}

Sources: Department of Statistics, Government of Jordan; Central Bank of Jordan; and staff estimates.

1/ Private investment is constructed from total gross fixed investment less central government capital expenditure. 
(excluding foreign grants) increased to 20 percent of GDP. Faced with growing budget deficits, the Government resorted to foreign commercial bank borrowing and to borrowing from the domestic banking sector. The monetization of the deficit led to higher inflation. Jordan's economy also remained highly vulnerable to the unfavorable fluctuations in income in the neighboring countries as a result of declining oll prices. The decline in workers' remittances and grants and loans from the neighboring oll-exporting countries led to a growing external imbalance and an associated rapid buildup of debt and debt service burden. By 1988, this external imbalance had reached unsustainable proportions. General financial instability in this period led to bank failures and a reduction in private capital inflows. Reflecting this deterlorated macroeconomic environment, aggregate investment declined to 22.3 percent of GDP, with private sector investment averaging only 7.1 percent of GDP. Real GDP declined at an average rate of 6.4 percent during 1986-1990, with the worst recession in the recent history of Jordan occurring in 1989 when real GDP contracted by 20.9 percent (Chart 8).

\section{d. Macroeconomic stabl112ation and economic recovery 1989-94}

Since 1989, Jordan has been implementing a medium-term structural adjustment program except for a temporary interruption in the aftermath of the 1990 regional crisis. During the period 1991-94, the macroeconomic policy indicators have shown signiflcant improvement. The inflation rate declined to 3.5 percent in 1994 and for the period the average rate of inflation was 4.8 percent. The fiscal deficit declined sharply averaging 10.8 percent of GDP. Including foreign grants and the effect of debt relief, central general operations on a cash basis was in surplus during most of the years (Chart 9). The improvement in macroeconomic indicators also led to a recovery in investment to 28.7 percent of GDP despite a significant decline in external officlal financing compared with earlier periods, and real economic activity expanded by about 7.4 percent per annum. The strengthening of Jordan's macroeconomic performance since late 1991 was attributable to three key factors: (1) the implementation of effective macroeconomic policies, such as restrained fiscal and monetary policy and prudent exchange rate management under the adjustment program; (11) the regularization of external debt service obligatiors, a prudent debt management policy which contributed to a sharp reduction in the debt and debt service ratios and substantial external financial support from official bilateral and multilateral creditors; and (11i) the effective absorption of some 300,000 Jordanians from abroad (about 10 percent of the population and a higher proportion of the labor force) into the Jordanian economy, who also brought with them substantial savings and technical know-how to revitalize the private sector. 
$-16 a-$

CHART 8

JORDAN

REAL GDP GROWTH AND INVESTMENT, 1977-94

(Percentage changes)

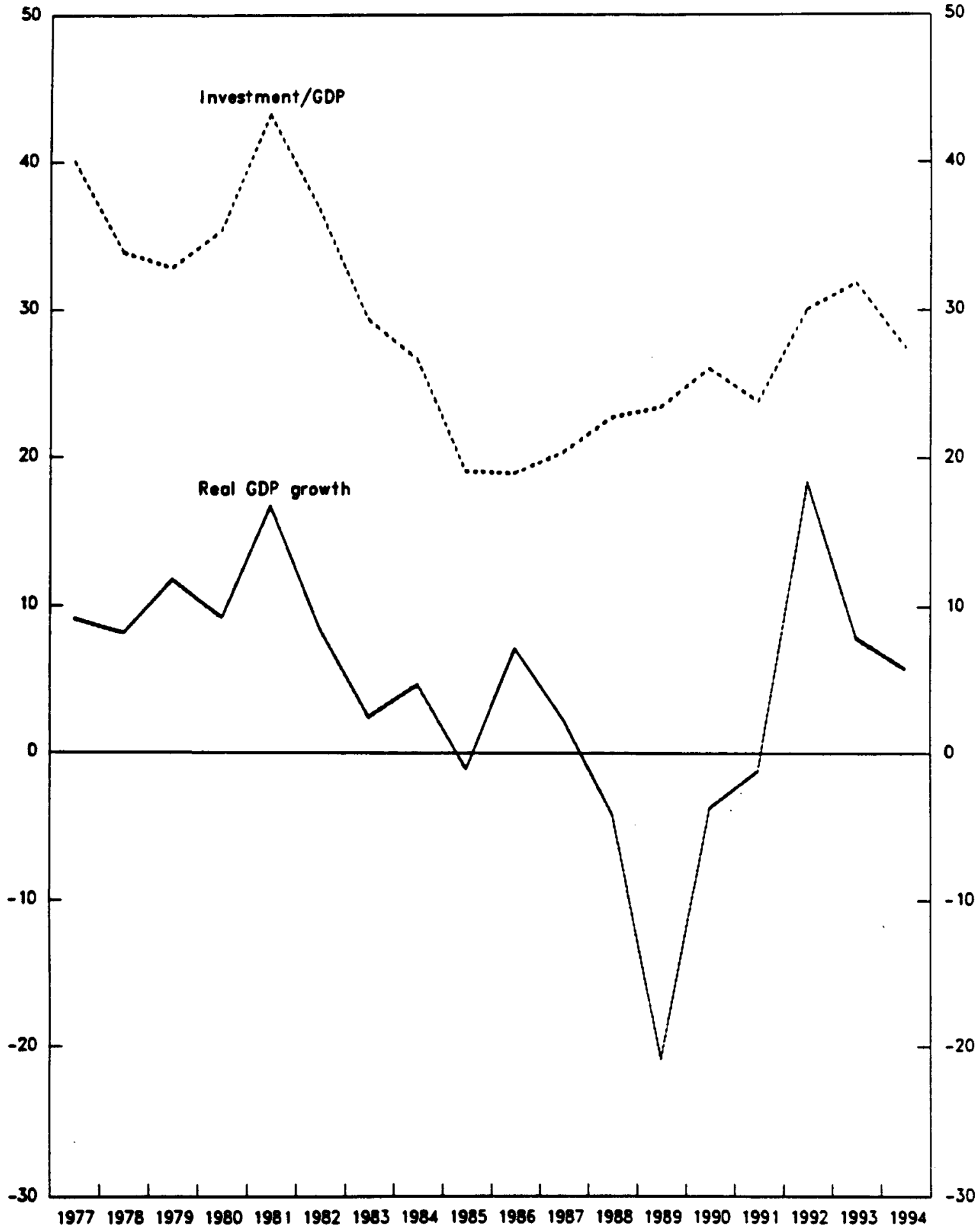

Source: Deportment of Statistics. Government of Jordan; Central Bank of Jordan. 


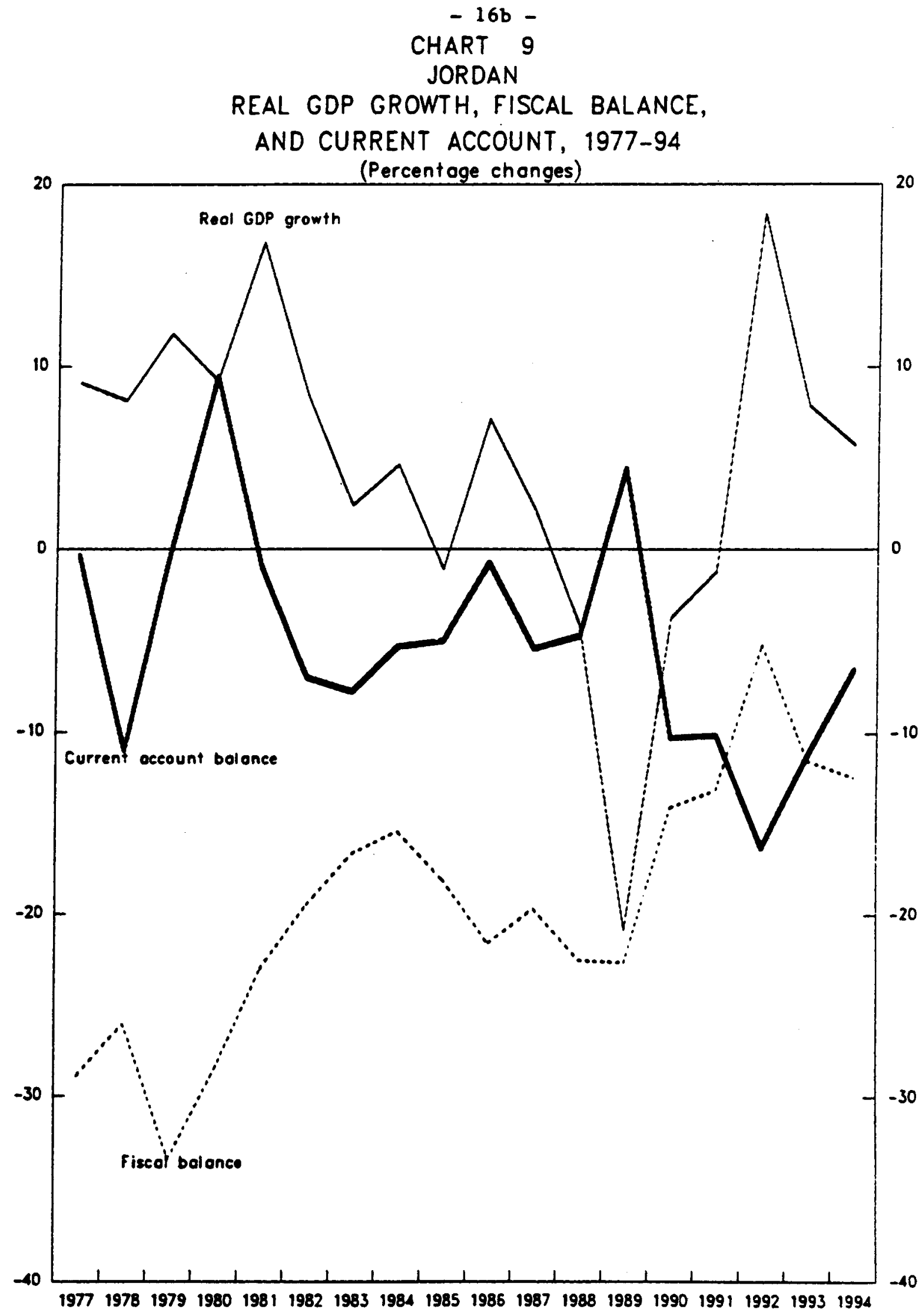

Source: Deportment of Statistics, Government of Jordon; Central Bonk of Jordon. 


\section{Eactors influencing lone-tem grouth}

\section{a. An overyilew}

Recent developeents in the growth literature have emphasized the role of econonic conditions and inplementation of proper public policies in influencing the rate of econonic growth. Barro, and Barro and Sala-iMartin $1 /$ link growth to fiscal variables in their endogenous growth models, which were tested empirically by Cashin $2 /$ for OECD countries. Fischer $3 /$ extends the notion that governments can influence growth by creating a stable macroecononic framowork. A stable nacroeconomic framework can be created through implementation of a set of ancroeconomic policies conducive to growth. $4 /$ The key macroecononic policies are considered to be monetary, fiscal and exchange rate policies designed to keep inflation low and predictable, a stable and sustainable government balance, appropriate real interest rates, a competitive and predictable real exchange rate, and viable balance of payments. One of the key mechanisms by which macroeconomic policies influence growth is via the signaling effect government management has on the private sector. To measure this signaling effect, Fischer recomends using a set of basic indicators of macroeconomic policy, such as the inflation rate, the government fiscal balance and the current account balance.

Fischer used a regression analog of growth accounting to identify the channels through which macroeconomic varlables affect economic growth. Growth can be attributed to changes in the supplies of factors of production (labor and capital) or to changes in total factor productivity (reflecting changes in the efficiency with which these factors are used). The Idea behind the growth accounting franework aployed by Flscher is to neasure the relationship between growth and several key macroeconomic variables.

\section{b. Macroeconomic stability and grouth}

Fischer estimated sets of panel regressions in order to examine the links between growth and Indicators of macroeconomic stability. All of the

1/ R. J. Barro, "Government Spending in a Simple Model of Endogenous Growth," Journal of Political Econony 1990, 98, pp. 103-125; and R. J. Barro and X. Sala-i-Martin, "Public Finance in Models of Economic Growth," Review of Fconomic Studies, 1992, 59, Pp. 645-661.

2 P. Cashin, "Government Spending, Taxes, and Economic Growth," IMF Staff Papers, 1995, 42, Pp. 237-269.

3/ S. Fischer, "Macroeconomics, Development, and Growth," NBER Macroeconomics Annual, 1991, $329-364$ and S. Fischer, "The Role of Macroeconomic Factors in Growth," Joumnl of Monetary Economics, 1993, PP. 485-512.

4/ Other public policies conducive to growth would include the enactment and enforcement of private property rights through the legal system and the maintenance of national security. 
coefficients from the estimated equation of the growth rate of real GDP from 1961 to 1988 on a set of macroeconomic indicators and external shock indicators are significantly different from zero (Table 3 ). $\mathrm{V}$

These results are used below to examine the effects of macroeconomic policies on Jordan's growth performance during the perlod 1976-94 (Table 4). First, the negative impact on growth of inflation for Jordan is about a third of a percentage point per annum over the period 1976-94. However, most of the impact came in the two periods 1976-80 and 1986-90. Had Jordan been able to maintain price stability in these two periods, the growth rates would have been nearly half a percentage point higher. However, even in the slump years, the restraining effect of inflation on growth is significantly less in Jordan than in all the countries in the sample. This reflects the fact that Jordan experienced relatively moderate rates of inflation over the entire period. Second, the changes in the terms of the trade have had a very Iimited and mostly positive impact in Jordan's growth performance.

Based on this analysis, the stance of fiscal policy has been the biggest impediment to Jordan's growth performance. Over the entire period 1976-94 deficit in the fiscal balance, including grants, restrained growth by an average of over 2 percentage points per annum. Had there been no grants--which have been used largely to finance public investment--growth would have been reduced by nearly 5 percentage points. Jordan's reliance on grants from oil-exporting countries in the region to finance public sector investment--a significant source of growth--has diminished over the period. If the grants received in the period $1976-80$ had not materialized, growth would have been reduced by an average of nearly 7 percentage points. However, if the grants received in the period 1991-94 had not materialized, growth would have been slower by an average of just over 2 percentage points.

\section{c. Total factor productivity residunls}

The World Bank $2 /$ conducted a study of sustalnable growth in Jordan, which included an analysis of total factor productivity. The approach uses a production function to examine the relative contribution to growth of

1 The results imply that : (1) a country that has an inflation rate 100 percentage points higher than another will have a growth rate that is 3.9 percent lower; (11) a country with a fiscal balance that is in greater surplus or lower deficit by 1 percent of GDP w1ll have a growth rate that is 0.23 percent larger; (111) a country with higher black aarket exchange premia will grow slower than a country with a lower black market exchange premia, other things being equal; and (iv) negative shocks in the terms of trade reduce growth. Overall, the results indicate that when the measures of macroeconomic policies indicate stability the prospects of growth are favorable.

2) Jordan: Consolidating Economic Adiustment and Establishing the Base for Sustainable Growth, 1994, Report No. 12645J0 (Washington, D.C.). 
Table 3. Summary of Estimated Panel Regreasion Coeficients from a Growh Accounting Framework 1/ 2/

\begin{tabular}{lcccc}
\hline & \multicolumn{4}{c}{ Regressors } \\
\cline { 2 - 5 } $\begin{array}{l}\text { Dependent } \\
\text { Variable }\end{array}$ & $\begin{array}{c}\text { Innation } \\
\text { Rate }\end{array}$ & $\begin{array}{c}\text { Fiscal } \\
\text { Balance } 3 /\end{array}$ & $\begin{array}{c}\text { Changes in } \\
\text { the Terms } \\
\text { of Trade }\end{array}$ & $\begin{array}{c}\text { Black Market } \\
\text { Exchange Rate } \\
\text { Premium }\end{array}$ \\
\hline Real GDP growth & -0.039 & 0.228 & 0.043 & -0.017 \\
& $(-4.65)$ & $(4.49)$ & $(2.71)$ & $(-2.76)$ \\
Productivity growth & -0.018 & 0.137 & 0.038 & -0.006 \\
Rate of capital accumulation & $(-2.49)$ & $(3.23)$ & $(2.60)$ & $(-1.17)$ \\
& $(-0.037$ & 0.075 & 0.008 & -0.019 \\
Labor force growth & $(1.61)$ & $(0.62)$ & $(-3.56)$ \\
& -0.002 & -0.007 & 0.0009 & 0.0003 \\
& $(-1.14)$ & $(-0.53)$ & $(0.29)$ & $(0.22)$ \\
\hline
\end{tabular}

Sources: S. Fischer, The Role of Macroeconomic Factors in Growth," Journal of Monetary Economics, 1993, 32, pp. 485-512.

1/ The number of countries in the panel regression is 22 . They are: Ghana, Cote d'Ivoire, Kenya, Malawi, Morocco, Zambia, Dominican Republic, Jamaica, Mexico, Argentina, Chile, Colombia, Ecuador, Paraguay, Venezuala, India, Indonesia, Korea, Pakistan. Thailand, Greece, and Turkey. 2/ Figures in parenthesis are 1 -statistics.

3/ In percent of GDP. 
Table 4. Jordan: Impact of Macroeconomic Policy on Real GDP Growth, 1976-94 1/ (In percentage change)

\begin{tabular}{lcccr}
\hline & \multicolumn{4}{c}{ Policy Indicators } \\
\cline { 2 - 5 } Period & $\begin{array}{c}\text { Inflation } \\
\text { Rate }\end{array}$ & $\begin{array}{c}\text { Fiscal Balance } \\
\text { Grants }\end{array}$ & $\begin{array}{c}\text { Including } \\
\text { Grants }\end{array}$ & $\begin{array}{c}\text { Changes in } \\
\text { Terms of } \\
\text { Trade }\end{array}$ \\
\hline $1976-80$ & -0.46 & -6.61 & -2.83 & -0.49 \\
$1981-85$ & -0.21 & -4.22 & -1.94 & 0.16 \\
$1986-90$ & -0.38 & -4.58 & -2.92 & 0.25 \\
$1991-94$ & -0.19 & -2.46 & -1.37 & 0.44 \\
$1976-94$ & -0.30 & -4.56 & -2.30 & 0.38 \\
\hline
\end{tabular}

Source: Staff estimates.

1/ The impact on real GDP growth is calculated by multiplying the period mean of the policy indicator (see Table 1) by the relevant estimated coefficient in Table 3. 
factors of production and productivity growth. The approach is a regression analog of growth accounting and allows for identification of the channels through which macroeconomic policies affect economic growth. Growth can arise through increased efficiency which shows up as increased positive residuals in an estinated production function or through increases in factors of production.

For this exercise, two specific types of production functions have been specified and estinated. The first one is a standard Cobb-Douglas production function, in which output is a function of labor and physical capital, while the second also includes a masure of human capital--measured by school enrollment--as an additional factor of production. The restriction that the two factors' share in the Cobb-Douglas production function are equal and satisfy constant returns to scale cannot be rejected using a standard hypothesis test. Based on the extended production function the estimated factor shares are: physical capital equal 44 percent, labor 23 percent and human capital 33 percent. For the first type of production function, total factor productivity estimates--the "Solow residuals"--are given by:

\section{Solow residuals - real GDP growth - 0.5 physical capital accumulation - 0.5 labor force growth;}

and for the second set of production function, total factor productivity estimates--the "Mankiw-Romer-Weil (MRW) residuals"-.are given by:

MRW residuals - real GDP growth - 0.44 physical capital accumulation - 0.23 labor force growth - 0.33 human capital.

Both the Solow residuals and the KRW residuals show that total factor productivity declined over the period 1981-94, with the largest decline over the perlod 1991-94 (Table 5). Estimates from the simple two factor production function show that the growth component provided by extra labor is more than offset by the declines in total factor productivity. implying that increased output from a higher labor force was virtually offset by a loss of productivity. However, estimates from the three factor production function, that allows decomposition between an increase in the quantity of labor and the quality of labor, show that for an increase in economic activity due to labor, about 50 percent can be attributed to an increase in quality. A striking feature of the results is that most of the growth in economic activity was generated by increases in physical capital. Below we examine how macroeconomic policy affects investment and thus, overall economic growth.

\section{Eactors influencine investment}

In view of the importance of investment in physical capital in generating growth in Jordan, this section conducts a detailed time series study of factors influencing private investment in Jordan. The factors chosen include some of the policy indicators that were shown to be important 
Table 5. Jordan: Contributions to Economic Growth by Factors of Production, 1976-94

(Period averages; percentage change in real terms)

\begin{tabular}{|c|c|c|c|c|c|c|}
\hline \multirow[b]{2}{*}{ Period } & \multirow[b]{2}{*}{ GDP } & \multicolumn{3}{|c|}{ Growth Contribution of } & \multirow[b]{2}{*}{$\begin{array}{c}\text { Solow } \\
\text { Residuals } \mathbb{1}\end{array}$} & \multirow[b]{2}{*}{$\begin{array}{c}\text { MRW } \\
\text { Residuals } 1 /\end{array}$} \\
\hline & & $\begin{array}{r}\text { Physical } \\
\text { Capital }\end{array}$ & $\begin{array}{l}\text { Labor } \\
\text { Force }\end{array}$ & $\begin{array}{l}\text { Human } \\
\text { Capital }\end{array}$ & & \\
\hline $1976-80$ & 9.5 & 6.5 & 1.3 & -- & 1.7 & - \\
\hline $1981-85$ & 6.2 & 7.0 & 2.7 & -- & -3.5 & -- \\
\hline $1986-90$ & -0.9 & 0.3 & 0.3 & -- & -1.5 & - \\
\hline $1991-94$ & 7.9 & 10.2 & 11.9 & -- & -14.2 & - \\
\hline $1976-94$ & 5.4 & 5.5 & 3.2 & -- & -3.3 & -- \\
\hline $1976-80$ & 9.5 & 5.7 & 0.6 & 1.2 & - & 2.0 \\
\hline $1981-85$ & 6.2 & 6.1 & 1.3 & 1.2 & -- & -2.4 \\
\hline $1986-872 /$ & 5.0 & 3.1 & 1.1 & 0.9 & -- & -0.1 \\
\hline 1976-872/ & 7.4 & 5.4 & 1.0 & 1.2 & - & -0.2 \\
\hline
\end{tabular}

Source: Staff estimates based on the World Bank repon--Jordan: Consolidating Economic Adjustment and Establishine the Base for Sustainable Growh, 1994, Washington, D.C.

1/ A measure of total factor productivity changes; see text for definition.

2) Data only available until 1987. 
determinants of growth in the previous section as well as some specific variables found to be empirically important for private sector investment behavior in Jordan.

\section{a. The nethodology and date}

The analysis is based on empirical estinates of a private investment function for Jordan during 1977-94. Private investment is specified to be a function of: (1) private external inflows--neasured by worker's remittances; (11) a public investment financing constraint--measured by the excess of central government capital expenditure over central government's avallable external financing; (111) a fiacal policy Indicator--measured by the fiscal deficit, excluding grants: (Iv) an indicator of the sustainability of financial policies--measured by official reserves; and $(v)$ an indicator of macroeconomic uncertainty--measured by changes in the real exchange rate. The rationale for using external inflows, government financing constraint, crowding-out effects, and uncertainty over policies and macroeconomic conditions as key factors influencing investment in Jordan are as follows:

(i) In many countries an important influence in Investment decisions is the availability of credit for financing the investaent. However, in the case of Jordan, the key source of financing of investnent has been through external inflows of private capital, in particular, through transfers of workers remittances and savings. Private investment in Jordan has fluctuated with the flows of workers renlttances, which depend heavily on the movements in oil prices in the Gulf countries.

(1i) The possibility of public investment, and fiscal policy in general, crowding-out private Investment--discussed in Easterly, Rodriguez and Schmidt-Hebbel $1 /$--may arlse from: (1) government preferential access to credit at administered interest rates: (11) increasing lending rates due to higher absorptions of funds by the public sector; or (11i) lower private rates of return because of goverment competition with the private sector for investment opportunities. In the case of Jordan, such potential crowding out is represented by the excess of central government capital outlays over available external financing.

(iii) Uncertainty about policy and the general macroeconomic environment give an incentive to investors to wait until the uncertainty has been removed before committing themselves to an irreversible decision. Uncertainty is not a measurable entity, but it is assuned that investors use some Indicators to gauge the level of uncertainty. In the case of Jordan, two such indicators are likely to be the level of official reserves and the real exchange rate.

IV W. Easterly, C.A. Rodriguez, and K. Schmidt-Hebbel, (eds.) Public Sector Deficits and Macroeconomic Performance, Oxford University Press, 1994. 
The data used to estimate the private investment equation are all annual time series covering the perlod 1977-94, making a total of 18 observations. Thus, any conclusions derived from this econometric exercise are tentative and should be considered with caution, given the low degree of freedom afforded by the small sample avallable. All the series entering the investment equation were expressed in scaled form (as a ratio of GDP or imports) or in rates of change to obtain a meaningful economic interpretation free of spurious correlations caused by unrelated trends in the data. Since a battery of diagnostic tests indicated the possible presence of heteroskedasticity, all standard errors are calculated using a heteroskedasticity-consistent variance-covariance matrix estimator. The diagnostic procedures do not indicate any other problems in the estimation and the estimated model explains 71 percent of the movements in private investment.

\section{b. Empirical observations}

The estimates suggest a very strong relationship between the availability of remittance income and private sector investment. The marginal propensity to invest from workers' remittances is estimated to be 0.85 and is statistically highly significant (Table 6). This finding shows the importance of external financing for Jordan: when the flow of remittances dries-up--as happened in the late 1980 s and early 1990s--private investment is constrained and growth is inhibited.

An equally strong but inverse relationship was found between private Investment and the excess of public investment over avallable grants. The estimated coefficient on this variable was $-C .81$, nearly equal but of opposite sign to the estimated coefficient on workers' remittances. Furthermore, an F-test of whether the estimated coefficients of the overall financing flows (workers' remittances plus the financing constraint) sum to zero is also statistically acceptable. The coefficient estimates and tests show that there is an exact one-for-one correspondence between public and private investment. Virtually all Jordanian investment is financed through external sources. If the Government invests more than its own internal public saving, then it must use financing that would have been avallable to the private sector. The size of the financing constraint means that the cost of public investment is the foregone opportunity in the private sector and that this cost will be fully reflected.

The estimated coefficients on official reserves and the real exchange rate show that these indicators of uncertainty provide a strong signal to Investors about the health of the economy and this in turn has a large impact on investment decisions. The estimated coefficient on official reserves is 1.94 and is statistically highly significant. The implication is that an improved reserve position would clearly enhance the prospects for private investment. The estimated coefficient on the real exchange rate is -0.23 and is significantly different from zero. The implication is that a devaluation is considered by the private sector as a sign of weak economy, and thus deters private investment, while maintaining real exchange rate 
Table 6. Jordan: Estimates of Private Investment Equation, 1977-94

(Dependent variable: private inveatment/GDP) 1

Independent

Variables

\section{Coeficient}

Estimate
Standard

Errors 2/
T-statistic
Constant

Workers' remittances/GDP

Govt. financing constraint 3 /

Official reserves

(in months of imports)

Real Exchange Rate

(in percentage change)

Fiscal deficit/GDP 4

\subsection{6}

0.85

$-0.81$

1.94

$-0.23$

0.50
3.34

0.23

0.18

0.53

0.10

0.12
1.25

3.64

4.22

Summary and diamostic statistics $5 /$

Number of observations

18

$\mathbf{R}$-squared

0.71

Durbin - Watson statistic

1.38

Breusch - Godfrey Test for AR(1) errors 6/

$1.77(0.18)$

Breusch - Pagan Test for heteroscadasticity 6/

$4.91(0.03)$

from workers' remittances

$1.18(0.28)$

Engle Test for ARCH errors 6/

$1.11(0.29)$

Sources: Staff estimates based on data provided by the Central Bank of Jordan and the Department of Statistics, Government of Jordan.

1/ Private investment was constructed from gross fixed investment less central government capital expenditure.

2/ Standard errors were computed using White's heteroskedasticity-consistent variance-covariance matrix estimator.

3/ The government financing constraint is defined as central governmeat capital expenditure in relation to GDP less central government external financing in relation to GDP.

4) Excluding foreign grants.

5) $\mathrm{P}$-values shown in parentheses.

6) Chi-squared test with one degree of freedom. 
stability would encourage confidence and thus investment. These results indicate that, Jordan's continued vulnerability to external shocks and the related perception of uncertainty in the macroeconomic environment tend to discourage domestic investment.

The estimated coefficient on the fiscal balance is 0.5 and is highly significant. The parameter estimate shows that there is a large crowdingout effect and that large fiscal deficits are the most important indicator of macroeconomic policy performance. A lack of fiscal discipline is a major factor which in the past significantly discouraged private investaent in Jordan. These findings are consistent with the strategy underpinning the thrust on fiscal adjustment and reserve buildup in Jordan's recent adjustment programs.

\section{Bublic Debt Dynamics and Fiscal Polley}

The size of public sector in Jordan has traditionally been very large, with the central government expenditures averaging about 43 percent of GDP over the last two decades. I Although foreign grants from the neighboring oil exporting Arab countries were very large, accounting for about 12 percent of GDP during this period, recourse to foreign and domestic debt financing was very large, averaging yearly about 10 percent of GDP over the period 1975-88 (Table 7). In the second half of the 1980s, with rising interest rates and later the depreciation of the Jordan dinar, the fiscal policy turned out to be unsustainable, calling for an urgent and comprehensive fiscal consolidetion effort. This section describes: (1) the origin of Jordan's fiscal imbalances and the growth of public debt in Jordan based on a debt dynamics accounting framework; (11) Government's fiscal adjustment and reform efforts since 1989, and their implications for the sustainability of the public debt; and (111) the medium-term fiscal 1ssues in the public sector.

1 Over the period 1972-94; In addition, Jordan's public sector also encompasses local authorities, decentralized agencles, financial and nonfinancial public enterprises, and unt1l 1991, extra-budgetary funds. Even if no quantitative estimation is available for the operations channeled thrcugh these public sector entities/bodies, they are belleved to be of sigulficant magnitude. Furthermore, purchases of military equipments through the Defense Fund, financed by foreign assistance, are not included in central government accounts. Due to the lack of adequate data, however, the analysis in the following section will concentrate on the budgetary operations of the central government. 
Table 7 : Jorian-Central Government Operations, 1975-1994 (in percentage of GDP)

\begin{tabular}{|c|c|c|c|c|c|c|c|c|c|c|c|c|}
\hline & 1975 & 1980 & 1985 & 1988 & 1989 & 1990 & $199 !$ & 1992 & 1993 & 1994 & $\begin{array}{l}\text { Avernge } \\
1975-88 \\
\end{array}$ & $\begin{array}{l}\text { Avernge } \\
1989.94 \\
\end{array}$ \\
\hline Total revenue & 22.3 & 19.2 & 21.8 & 24.0 & 23.8 & 27.5 & 28.2 & 33.5 & 30.0 & 29.2 & 21.5 & 28.8 \\
\hline $\begin{array}{l}\text { Tax revenue } \\
\text { Of which }\end{array}$ & 13.8 & 11.5 & 12.2 & 11.3 & 11.5 & 14.8 & 14.7 & 18.5 & 16.6 & 16.3 & 12.1 & 15.4 \\
\hline $\begin{array}{l}\text { On income \& profits } \\
\text { On domestic trans. } \\
\text { On foreign trade }\end{array}$ & $\begin{array}{l}2.2 \\
4.0 \\
7.6\end{array}$ & $\begin{array}{l}2.4 \\
1.7 \\
7.5\end{array}$ & $\begin{array}{l}2.7 \\
2.9 \\
5.9\end{array}$ & $\begin{array}{l}1.9 \\
3.5 \\
5.2\end{array}$ & $\begin{array}{l}2.2 \\
4.4 \\
4.4\end{array}$ & $\begin{array}{l}4.3 \\
4.5 \\
4.4\end{array}$ & $\begin{array}{l}3.3 \\
4.6 \\
4.8\end{array}$ & $\begin{array}{l}3.1 \\
5.2 \\
8.2\end{array}$ & $\begin{array}{l}3.1 \\
5.8 \\
6.1\end{array}$ & $\begin{array}{l}3.2 \\
6.4 \\
5.2\end{array}$ & $\begin{array}{l}2.3 \\
2.5 \\
7.1\end{array}$ & $\begin{array}{l}3.2 \\
5.1 \\
5.5\end{array}$ \\
\hline Nontax reventue & 8.5 & 7.6 & 9.6 & 12.7 & 12.3 & 12.7 & 13.5 & 15.0 & 13.5 & 12.9 & 9.3 & 13.4 \\
\hline $\begin{array}{l}\text { Total expenditure } 1 / \\
\text { Of which }\end{array}$ & 54.0 & 43.5 & 36.7 & 41.2 & 45.8 & 42.6 & 41.9 & 37.3 & 36.3 & 35.5 & 41.6 & 40.0 \\
\hline $\begin{array}{l}\text { Primary exp. } \\
\text { Current prim. exp. } \\
\text { Civil curr. prim. exp. }\end{array}$ & $\begin{array}{l}52.9 \\
31.9 \\
19.2\end{array}$ & $\begin{array}{l}42.3 \\
27.2 \\
17.0\end{array}$ & $\begin{array}{l}32.8 \\
24.3 \\
13.2\end{array}$ & $\begin{array}{l}34.4 \\
25.3 \\
14.0\end{array}$ & $\begin{array}{l}36.3 \\
28.0 \\
17.3\end{array}$ & $\begin{array}{l}32.2 \\
26.2 \\
16.6\end{array}$ & $\begin{array}{l}31.3 \\
25.5 \\
16.0\end{array}$ & $\begin{array}{l}28.2 \\
22.4 \\
14.1\end{array}$ & $\begin{array}{l}29.7 \\
23.3 \\
15.0\end{array}$ & $\begin{array}{l}30.0 \\
23.7 \\
15.2\end{array}$ & $\begin{array}{l}39.3 \\
26.5 \\
14.9\end{array}$ & $\begin{array}{l}31.4 \\
25.0 \\
15.8\end{array}$ \\
\hline $\begin{array}{l}\text { Current expenditure } \\
\text { Of which }\end{array}$ & 33.0 & 28.5 & 28.3 & 32.1 & 37.5 & 36.6 & 36.0 & 31.5 & 29.8 & 29.2 & 28.8 & 33.5 \\
\hline $\begin{array}{l}\text { Wages and salaries } \\
\text { Goods a services } \\
\text { Intereat paymeats } \\
\text { Subsidies } \\
\text { Militury outlays } \\
\text { Other outlays }\end{array}$ & $\begin{array}{r}\ldots \\
\ldots \\
1.1 \\
2.2 \\
12.7 \\
\ldots\end{array}$ & $\begin{array}{r}\ldots \\
1.2 \\
4.0 \\
10.2 \\
\cdots\end{array}$ & $\begin{array}{r}5.5 \\
2.5 \\
1.0 \\
1.7 \\
11.1 \\
3.6\end{array}$ & $\begin{array}{r}6.5 \\
2.4 \\
6.8 \\
0.8 \\
11.4 \\
4.3\end{array}$ & $\begin{array}{r}6.5 \\
2.0 \\
9.5 \\
3.1 \\
10.6 \\
5.7\end{array}$ & $\begin{array}{r}6.1 \\
1.6 \\
10.3 \\
3.3 \\
9.6 \\
5.6\end{array}$ & $\begin{array}{r}6.5 \\
2.1 \\
10.5 \\
2.1 \\
9.4 \\
5.2\end{array}$ & $\begin{array}{l}6.0 \\
2.0 \\
9.1 \\
1.6 \\
8.3 \\
4.4\end{array}$ & $\begin{array}{l}6.4 \\
1.9 \\
6.5 \\
1.4 \\
8.3 \\
5.4\end{array}$ & $\begin{array}{l}6.9 \\
2.0 \\
5.5 \\
1.0 \\
8.5 \\
5.3\end{array}$ & $\begin{array}{r}3.2 \\
1.4 \\
2.3 \\
1.8 \\
11.7 \\
2.0\end{array}$ & $\begin{array}{l}6.4 \\
2.0 \\
8.6 \\
2.1 \\
9.1 \\
5.3\end{array}$ \\
\hline Capital expenditure & 21.0 & 15.0 & 8.5 & 9.1 & 8.3 & 6.0 & 5.9 & 5.8 & 6.4 & 6.4 & 12.8 & 6.5 \\
\hline $\begin{array}{l}\text { Fiscal balance, excl. grants } 1 \text { ' } \\
\text { Of which }\end{array}$ & -31.7 & -24.3 & -14.9 & -17.2 & -22.0 & -15.0 & -13.7 & -3.8 & -6.3 & -6.4 & -20.1 & -11.2 \\
\hline Primary balance & -30.7 & -23.1 & -10.9 & -10.4 & -12.4 & -4.7 & -3.1 & 5.3 & 0.2 & -0.9 & -17.8 & -2.6 \\
\hline Net lending a extrabudg. oper. $\underline{l}$ & $\cdots$ & 2.2 & 6.2 & 6.2 & -1.4 & 3.3 & 3.7 & -0.4 & -0.6 & -0.5 & 2.4 & 0.7 \\
\hline $\begin{array}{l}\text { Fiscal halance, excl. granls } \\
\text { Of which }\end{array}$ & -31.7 & -26.5 & -21.1 & -23.5 & -20.6 & -18.3 & -17.4 & -3.4 & -5.6 & -5.9 & -22.5 & -11.9 \\
\hline Primery balance & -30.7 & -25.3 & -17.1 & -16.7 & -11.1 & -8.0 & -6.8 & 5.7 & 0.9 & -0.4 & -20.2 & -3.3 \\
\hline Grants & 15.9 & 17.7 & 13.0 & 8.6 & 12.8 & 10.9 & 8.7 & 3.9 & 4.3 & 3.4 & 12.6 & 7.3 \\
\hline Fiscal balance, incl. grants & -15.9 & -8.8 & -8.1 & -14.9 & -7.8 & -7.4 & -8.7 & 0.5 & -1.3 & -2.5 & -9.9 & -4.5 \\
\hline
\end{tabular}

$1 /$ Excluding extrabudgetary expenditure and net lending.

2/ Net lending date are available from 1978 onwards and extrabudgetary ones from 1985 onwards. 
1. Historical background and the build-up of public debt (1972-88)

\section{a. Origin of the problem}

Jordan's high fiscal expenditure until early 1980s, equivalent to almost half the GDP, was largely attributable to two major components: capital expenditure and milltary outlays. Together, those two components accounted for about 62 percent of total central government outlays and 32 percent of GDP. Capital expenditures--a large part of which was financed from external sources--remained extremely buoyant between 1973 and 1983 (averaging 15 percent of GDP) and then declined to a more sustainable level ( 9 percent on average between 1984 and 1988) (Charts 10 and 11). Like most countries in the region Jordan allocated substantial resources to national defence, which given the very narrow production base of the economy was extremely burdensome. Military expenditures--even with a narrowly defined base--accounted for more than 10 percent of GDP over the 1970 s and 1980s. I Such expenditures have accounted for much of the fiscal deficit and accumulation of forelgn debt. Not only domestic revenue-21 percent of GDP on average between 1972 and 1988 -.was largely insufficient to finance the high level of expenditure, but its structure was also unbalanced, with taxes on foreign trade providing nearly two-thirds of total tax revenue (Chart 12).

Jordan could historically sustain such a large public expenditure program largely because of: (i) large receipts of foreign grants, which despite some year-to-year fluctuations remained high until the regional crisis of 1990; and (1i) low interest rate, on average, on public debt (significantly below the growth rate of the economy). Notwithstanding the sizable recelpts of grants. the overall fiscal deficit including grants was averaging 10 percent of GDP during 1972-1988, which was primarily financed by external borrowing. In the initial period through 1983, interest payments were relatively modest accounting for less than 2 percent of GDP (Chart 13). Thereafter, interest payments increased steadily in response to the rapid build-up in debt and increases in interest rates in the forelgn markets. Interest payments peaked to an unsustalnable level of 10.7 percent of GDP during 1990-91, on a commitment basis. Tre rapid increase in interest payments after 1988 in part reflected the effect of a sharp depreclation of the Jordan dinar in 1988-89 associated with the balance of payments crisis.

An important feature of the economic environment of the 1980s was the combination of high interest rates in the world market and moderate economic growth in Jordan, which implied a more rapid growth in the debt to GDP ratio than would otherwise be the case. This characteristic of the environment also meant that the Government's solvency constraint-.the condition that the

1 The figure does not include pensions payments nor purchases of military equipments through the Defense Fund, generally secured from external sources under varlous bilateral military aid programs. 


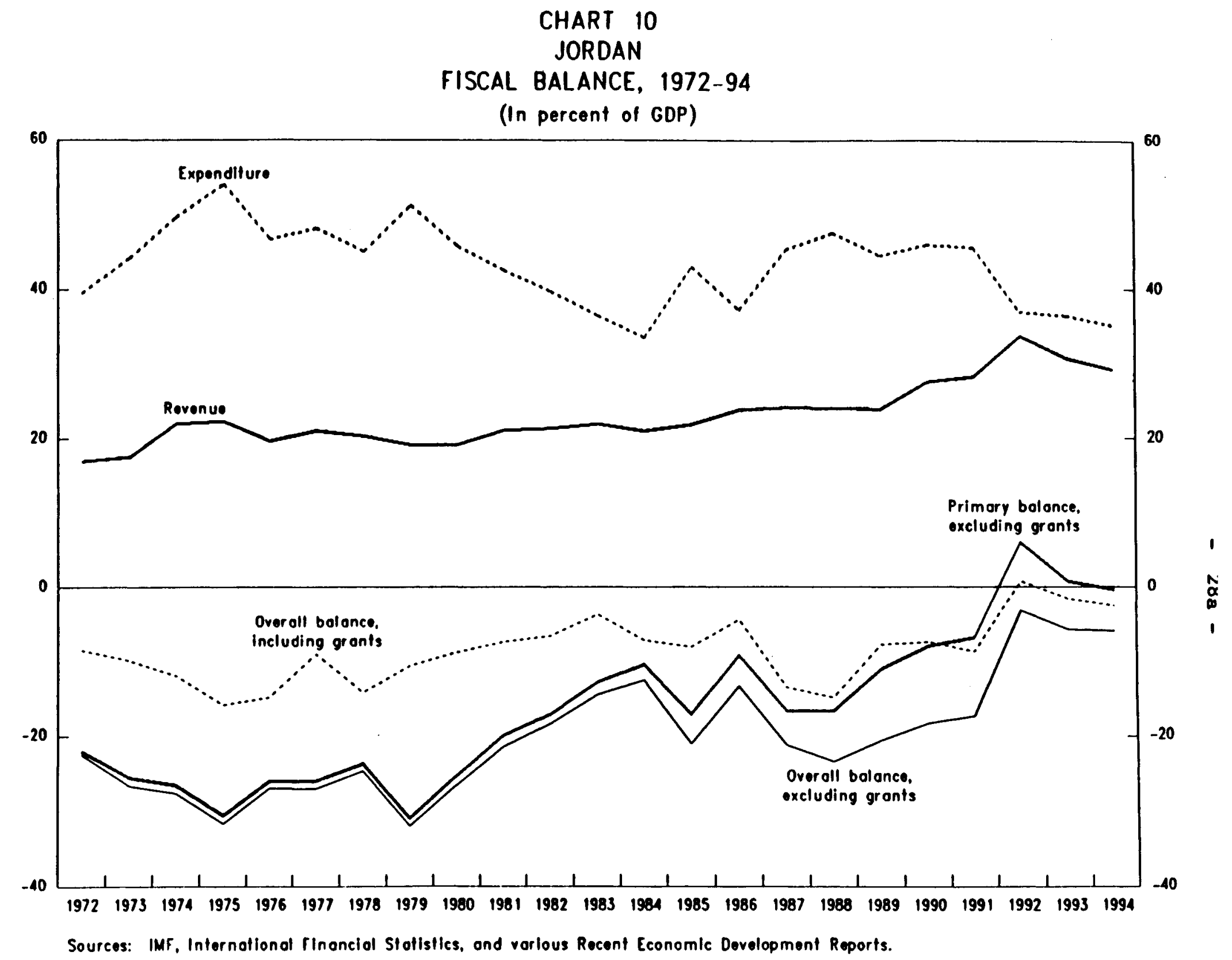

CInternational Monetary Fund. Not for Redistribution 
CHART 11

JORDAN

EXPENDITURE, 1972-94

(In percent of GDP)

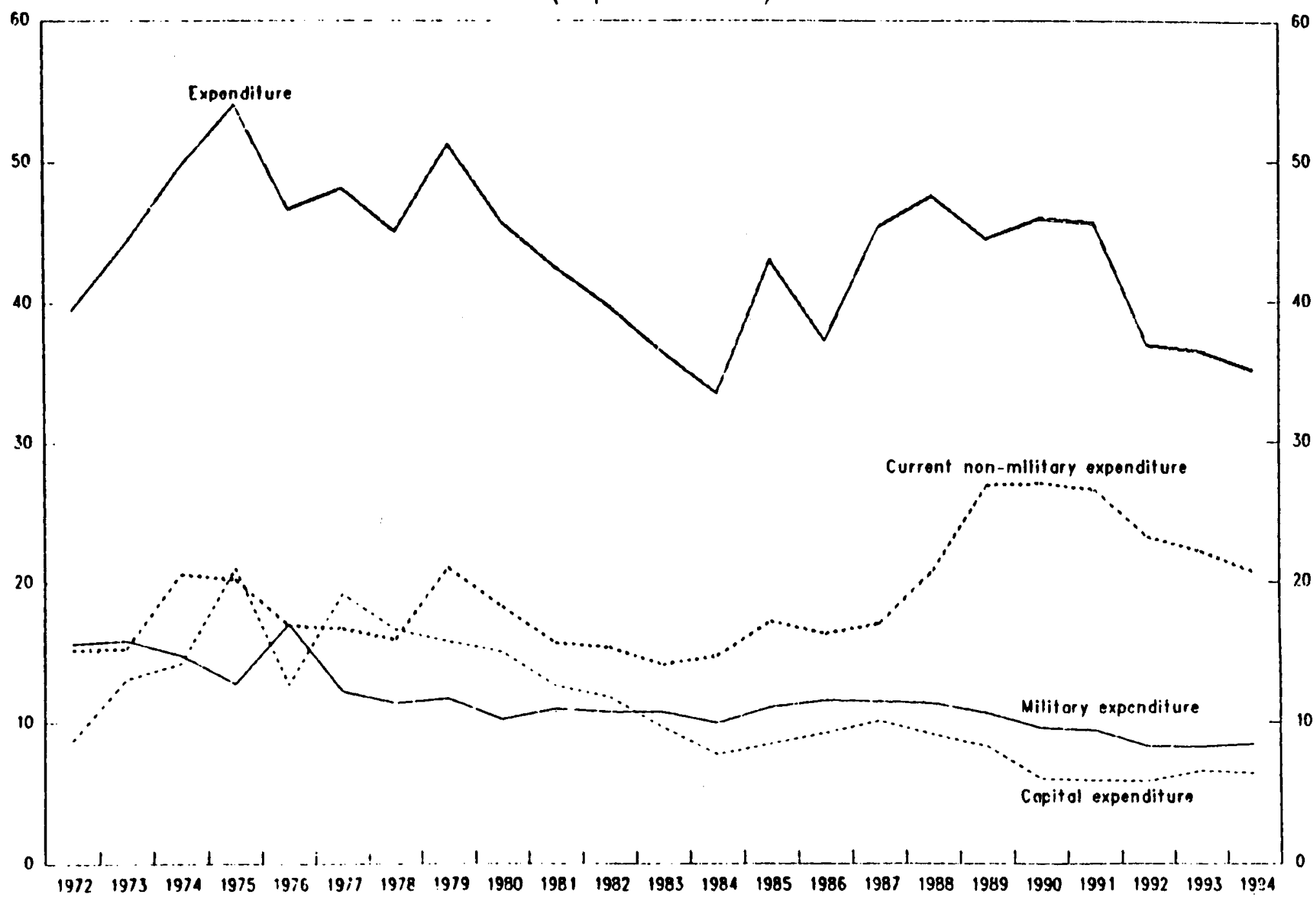

Sources: IMF. International financial Statistics, and various Recent Economic Development Reports.

CInternational Monetary Fund. Not for Redistribution 


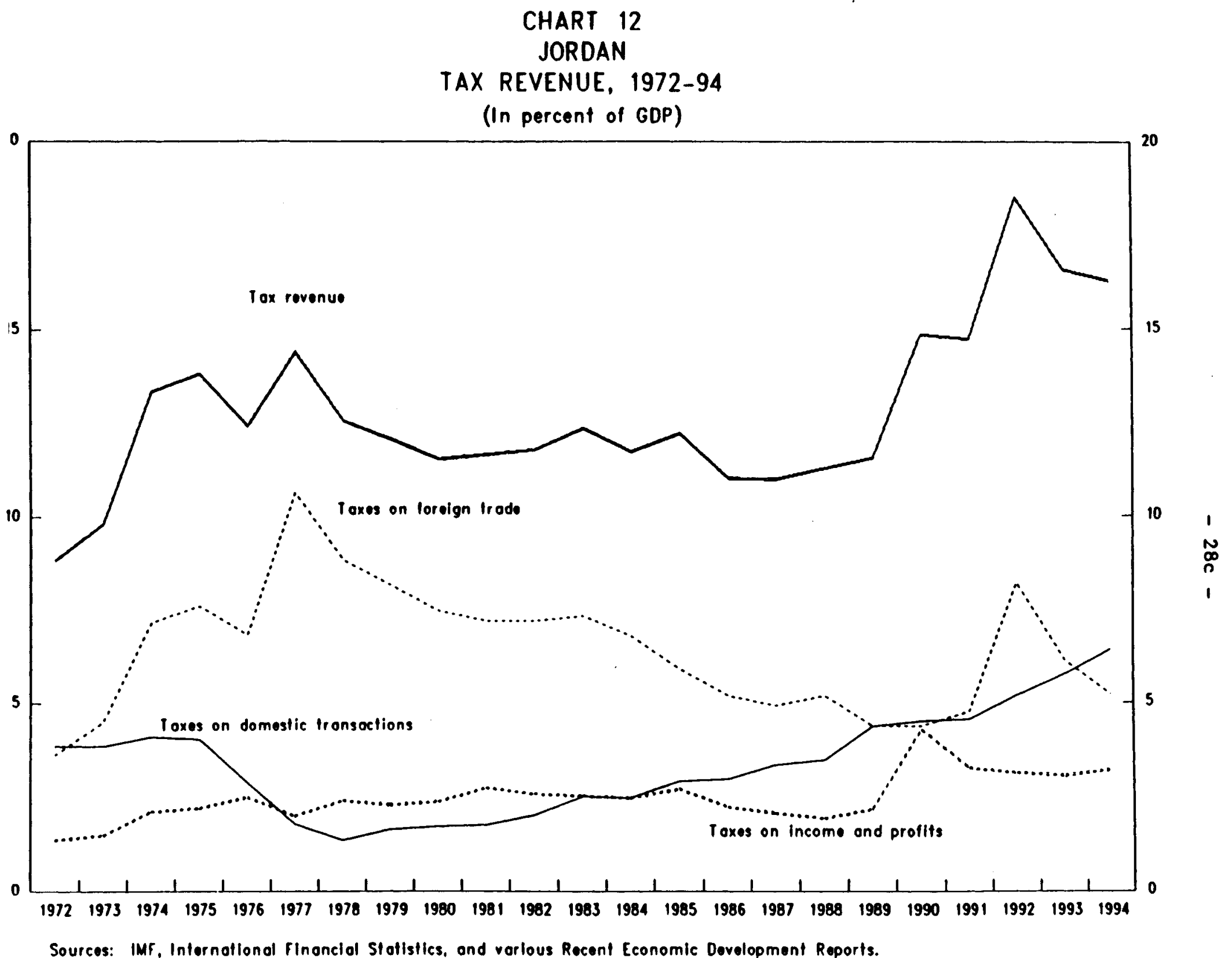




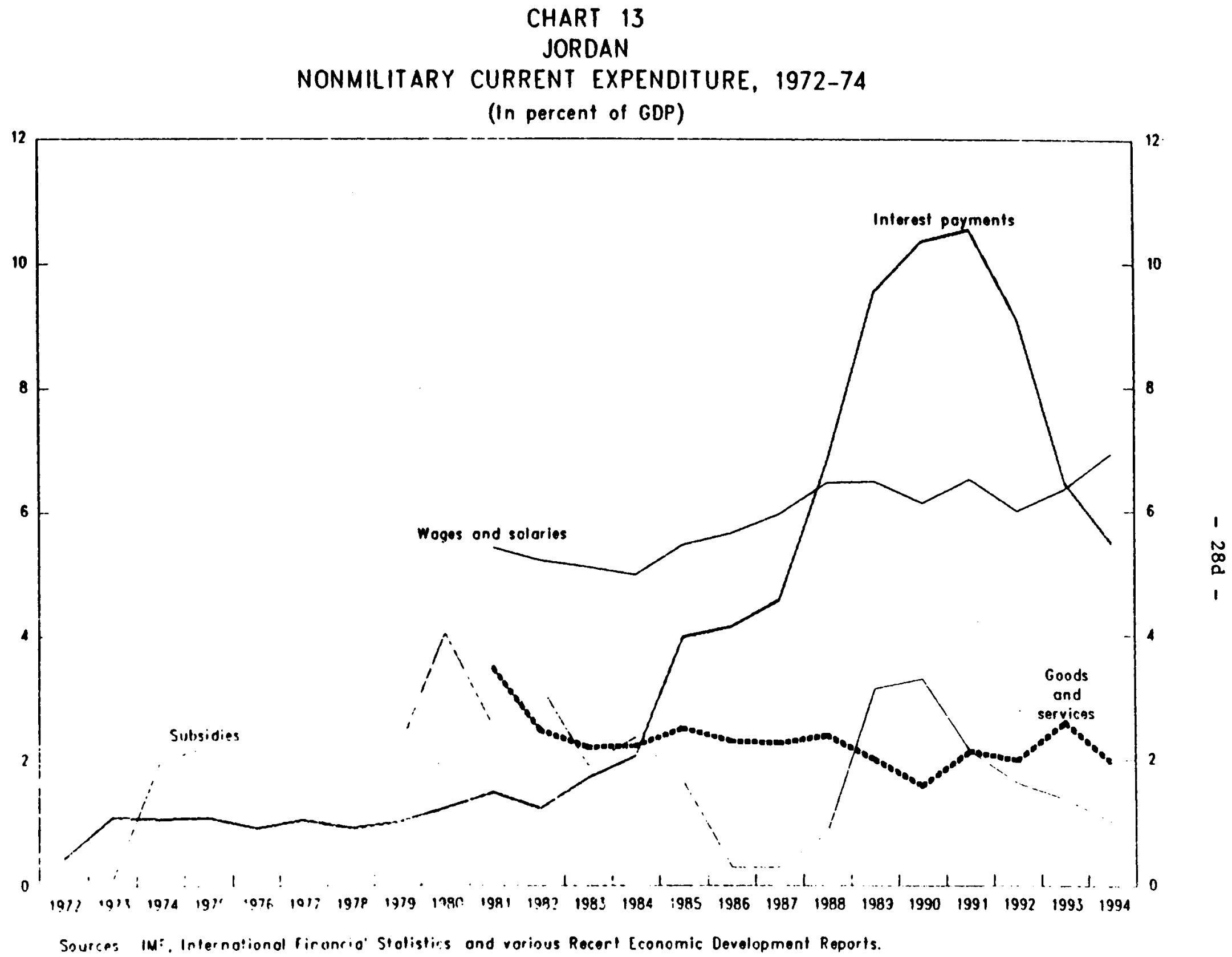


value of outstanding public debt is no greater than the sum of the present discounted values of expected prinary surpluses and high-powered money-became binding on the operation of fiscal policy. For example, in 1988, just prior to the balance of payments crisis, tax and nontax revenues awounted to 11.3 percent and 12.7 percent of GDP, respectively, and total expenditure reasined at 41.2 percent of GDP, out of which 7 percentage points were attributable to debt service, and capital expenditure accounted for 9 percentage points. With forelgn grants equivalent to almost 9 percent of GDP, the overall fiscal deficit, including grants, was 15 percent of GDP. Reflecting the cumulative effect of such policles, the public debt ratio reached almost 100 percent of GDP (Chart 14).

\section{b. Debt accounting fromevork}

In order to analyze the debt dynnics, the growth of the public debt ratio can be decomposed into five major components based on the standard budget financing identity: (1) the structural component as determined by the underlying structural fiscal balance depending on trends in revenue and expenditure; (1i) output variation coaponent reflecting movenents in domestic economic activity compared with the trend output; (111) the evolution of interest payments; (iv) the exchange rate effect; and ( $v$ ) the annual discretionary fiscal impulse. The structural component is defined as the average primary deficit adjusted for variations in domestic output. The output varlation component of the budget deficit reflects variations in revenue resulting from deviations in econonic activity from its potential trend level. W The fiscal stance could be defined as expansionary (contractionary) relative to the base year if the actual prinary deficit exceeds (falls short of) the cyclically adjusted deficit, where the base year is a period in which actual output and potential are assumed to be equivalent, and the fiscal stance is neutral. The fiscal stance, in this sense, measures the magnitude of the stimulus infected (withdrawn) through the budget into (from) donestic aggregate denand and beyond the primary deficit implied by the structure of budgetary operations in the base period. The exchange rate effect natters in countries where the proportion of public debt denominated in forelgn currencles is large and where the exchange rates vis-a-vis currencies in which the extermal debt is denoninated have fluctuated significantly.

Change in the stock of debt (D) on account of central government operations can be decomposed as follows:

$$
\begin{aligned}
D_{t}-D_{t-1} & =-\left(t_{a}-B_{a}\right) \cdot Y P_{t}-t_{a} \cdot\left(Y_{t}-Y P_{t}\right)+I_{t} \cdot D_{t-1} \\
& +F D_{t-1} \cdot\left(\left(E R_{t-1} / E R_{t}\right)-1\right)-I B_{t}
\end{aligned}
$$

1 Primary expenditures are assuned not to be affected by cyclical fluctuations, a reasonable assumption given the absence of unemployment insurance schene in Jordan. Instead of using "base-year" approach, as it is most often the case when estimating trend values, the methodology used here is based on average values. 
with $t_{a}$ and $g_{a}$ the average ratio of revenue and primary experditure, respectively, to GDP over the period 1975-88; $Y_{t}$ and $\mathrm{YP}_{t}$ nominal and potential GDP at current prices in year $t ; r_{t}$ the nominal implicit interest rate on public debt in year $t$; $D_{t}$ the net stock of pubilc debt at the end of year $t ; F_{t}$ the net stock of foreign currency denoninated public debt at the end of year $t$; $E R_{t}$ the average nominal exchange rate (per unit of donestic currency); and $I B_{t}$ the discretlonary primary balance in year $t$. Appendix I provides a detailed methodology. 1

Right-hand side of equation (1) reflects the five aforementioned components, 1.e.. respectively, the structural component, the output variation effect, Interest payments, the exchange rate effect, and the annual discretionary component. The change in the debt ratio can in a reduced form be expressed as the opposite of overall fiscal balance (Bt. corrected for the excharige rate effect). In turn, the fiscal balance can be decomposed along the same line, as follows:

$$
B_{t}-\left(t_{a}-B_{a}\right) \cdot Y P_{t}+t_{a} \cdot\left(Y_{t}-Y P_{t}\right)-I_{t} \cdot D_{t-1}+I B_{t}
$$

The fiscal balance reflects the difference between structural revenue and primary expenditure, the cyclical output gap, the debt service burden and the yearly fiscal impulse.

\section{c. Debt dymanlcs in Jordan and its sustainability 1975-88}

Between 1974 and 1988, the ratio of outstanding central government debt to CDP increased from 65 percent to 95 percent (Table 8). 2/ A decomposition of annual fiscal balances indicates that out of the average annual

16 The dabt dynamics can be expzessed 1:, relation to GDP as:

(2) $\left.D_{t} / Y_{t} \cdot D_{t-1} Y_{t-1}-i t_{a}-B_{a}\right) \cdot Y P_{t} N_{t} \cdot i_{a} \cdot\left(Y_{t}-Y P_{t}\right) N_{t}$ $+I_{t} \cdot D_{t-1} / \sim_{t-1}+\left(F_{t-1} / Y_{t-I}\right) \cdot\left(\left(E R_{t-1} / E_{t}\right)-i\right) \cdot I E_{t} / Y_{t}$ - $\left(g_{t} \prime\left(1+g_{t}\right)\right) \cdot\left(\left(1+r_{t}\right) \cdot D_{t-1} / Y_{t-1}+\left(F D_{t} / Y_{t-1}\right) \cdot\left(\left(L R_{t-1} / E_{R_{t}}\right)-1\right)\right)$

with $g_{t}$ the nominal rate of GDP growth in year $t$. The last two components of the right-hand side of equation (2) are essentlally odjustment terms due to the fact that output in denominator relates to different years. These adjustment rerms would vanish if actual curzent output is used as the common cenowinator.

2) For the purpose of this empirical analysis, central government debt is defined to be limited to obligations arising frum fiscal deficits accumulated over a certain period of time. Accordingly, the stock of outstanding debt and its accumulation--based on the analysis presented in this section--is different from the corresponding figures noted in other sections of this paper. 
DEBT TO GDP RATIO, 1974-94

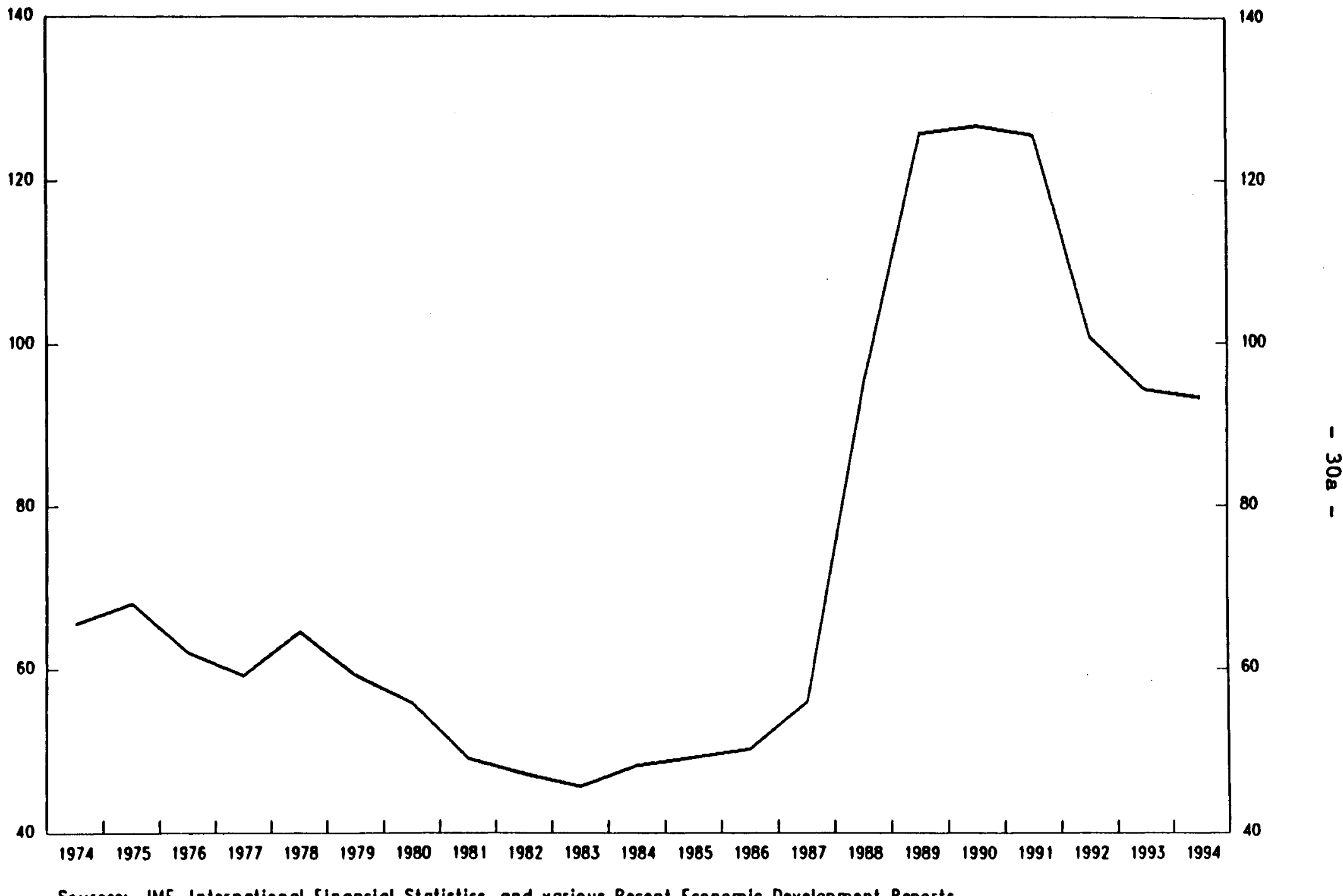

Sources: IMF. Internotional financial Statistics, ond vorious Recent Economlc Devolopment Reports. 
This page intentionally left blank 


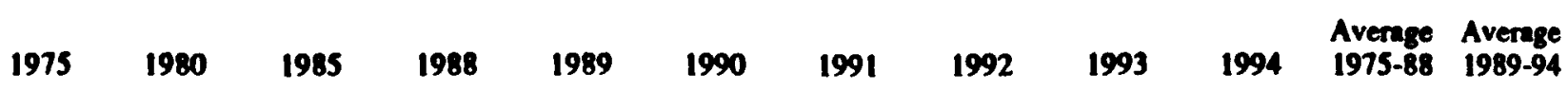

\begin{tabular}{|c|c|c|c|c|c|c|c|c|c|c|c|c|}
\hline $\begin{array}{l}\text { Observed GDP (M) } \\
\text { Public dobt 1/ 2/ } \\
\text { Of which } \\
\text { Domestic debt } \\
\text { Foreign dabt } \\
\text { Public debt varietion } \\
\text { Fiscal balance 2/ } \\
\text { Primary balance } \\
\text { Interest charges } \\
\text { Grants } \\
\text { Exchange rale effect } \mathbf{3} \text { / }\end{array}$ & $\begin{array}{r}379.1 \\
257.8 \\
\\
65.4 \\
192.4 \\
60.9 \\
-60.2 \\
-116.2 \\
4.1 \\
60.1 \\
-0.7\end{array}$ & $\begin{array}{r}1180.3 \\
658.6 \\
\\
197.8 \\
460.8 \\
78.1 \\
.78 .1 \\
-272.9 \\
14.5 \\
209.3 \\
0.0\end{array}$ & $\begin{array}{r}2020.2 \\
992.7 \\
\\
347.2 \\
645.5 \\
38.9 \\
-38.9 \\
-221.2 \\
80.3 \\
262.6 \\
0.0\end{array}$ & $\begin{array}{r}2264.4 \\
2154.2 \\
\\
903.6 \\
1250.6 \\
918.8 \\
-195.5 \\
-236.0 \\
154.3 \\
194.8 \\
-723.3\end{array}$ & $\begin{array}{r}2372.1 \\
2980.0 \\
\\
976.7 \\
2003.3 \\
825.8 \\
-216.9 \\
-295.0 \\
226.2 \\
304.3 \\
-608.9\end{array}$ & $\begin{array}{r}2668.3 \\
3376.0 \\
\\
1019.2 \\
2356.8 \\
396.0 \\
-109.2 \\
-124.9 \\
276.0 \\
291.7 \\
-286.8\end{array}$ & $\begin{array}{r}2855.1 \\
3581.2 \\
1021.4 \\
2559.8 \\
205.2 \\
-143.0 \\
-89.8 \\
300.8 \\
247.6 \\
-62.2\end{array}$ & $\begin{array}{r}3493.0 \\
3517.5 \\
\\
1004.2 \\
2513.3 \\
-63.7 \\
10.5 \\
191.0 \\
317.9 \\
137.4 \\
53.4\end{array}$ & \begin{tabular}{r|}
3882.5 \\
3660.1 \\
\\
1059.1 \\
2601.0 \\
142.6 \\
-84.4 \\
6.4 \\
251.0 \\
160.2 \\
-58.2
\end{tabular} & $\begin{array}{r}4266.2 \\
3960.6 \\
\\
1059.1 \\
2921.5 \\
320.4 \\
-126.1 \\
-36.9 \\
234.5 \\
145.3 \\
-194.3\end{array}$ & & \\
\hline & \multicolumn{12}{|c|}{ (In percentage of GDP) } \\
\hline $\begin{array}{l}\text { Public debt } \\
\text { of which }\end{array}$ & 68.0 & 55.8 & 49.1 & 95.1 & 125.6 & 126.5 & 125.4 & 100.7 & 94.3 & 93.3 & 57.8 & 111.0 \\
\hline $\begin{array}{l}\text { Domedic debt } \\
\text { Foreign debt } \\
\text { Public debt variation } \\
\text { Fiscal balance } 2 \text { J } \\
\text { Primary balence } \\
\text { Interest charges } \\
\text { Grants } \\
\text { Exchenge rate effect } 3 /\end{array}$ & $\begin{array}{r}17.3 \\
50.7 \\
16.1 \\
-15.9 \\
-30.7 \\
1.1 \\
15.9 \\
-0.2\end{array}$ & $\begin{array}{r}16.8 \\
39.0 \\
6.6 \\
-6.6 \\
-23.1 \\
1.2 \\
17.7 \\
0.0\end{array}$ & $\begin{array}{r}17.2 \\
32.0 \\
1.9 \\
-1.9 \\
-10.9 \\
4.0 \\
13.0 \\
0.0\end{array}$ & $\begin{array}{r}39.9 \\
55.2 \\
40.6 \\
-8.6 \\
-10.4 \\
6.8 \\
8.6 \\
-31.9\end{array}$ & $\begin{array}{r}41.2 \\
84.5 \\
34.8 \\
-9.1 \\
-12.4 \\
9.5 \\
12.8 \\
-25.7\end{array}$ & \begin{tabular}{r|}
38.2 \\
88.3 \\
14.8 \\
-4.1 \\
-4.7 \\
10.3 \\
10.9 \\
-10.7
\end{tabular} & $\begin{array}{r}35.8 \\
89.7 \\
7.2 \\
.5 .0 \\
-3.1 \\
10.5 \\
8.7 \\
-2.2\end{array}$ & $\begin{array}{r}28.7 \\
72.0 \\
-1.8 \\
0.3 \\
5.5 \\
9.1 \\
3.9 \\
1.5\end{array}$ & $\begin{array}{r}27.3 \\
67.0 \\
3.7 \\
-2.2 \\
0.2 \\
6.5 \\
4.1 \\
-1.5\end{array}$ & $\begin{array}{r}24.8 \\
68.5 \\
7.5 \\
-3.0 \\
-0.9 \\
5.5 \\
3.4 \\
-4.6\end{array}$ & $\begin{array}{r}18.8 \\
38.9 \\
9.9 \\
-7.6 \\
-17.8 \\
2.3 \\
12.6 \\
-2.3\end{array}$ & $\begin{array}{r}32.7 \\
78.3 \\
11.0 \\
-3.8 \\
-2.6 \\
8.6 \\
7.3 \\
-7.2\end{array}$ \\
\hline Exchenge rale effect $\mathbf{3}$ / & \multicolumn{12}{|c|}{ (In percentage) } \\
\hline $\begin{array}{l}\text { Implicit interest rate (r) } \\
\text { hutput growth (g) } \\
\text { terest-output differ. (r-g) }\end{array}$ & $\begin{array}{r}2.1 \\
26.2 \\
-24.1\end{array}$ & $\begin{array}{r}2.5 \\
20.3 \\
-17.8\end{array}$ & $\begin{array}{l}8.4 \\
2.0 \\
6.5\end{array}$ & $\begin{array}{r}12.5 \\
2.5 \\
10.0\end{array}$ & $\begin{array}{r}10.5 \\
4.8 \\
5.7\end{array}$ & $\begin{array}{r}9.3 \\
12.5 \\
-3.2\end{array}$ & $\begin{array}{l}8.9 \\
7.0 \\
1.9\end{array}$ & $\begin{array}{r}8.9 \\
22.3 \\
-13.5\end{array}$ & $\begin{array}{r}7.1 \\
11.2 \\
4.0\end{array}$ & $\begin{array}{r}6.4 \\
9.9 \\
-3.5\end{array}$ & $\begin{array}{r}4.8 \\
16.1 \\
-11.3\end{array}$ & $\begin{array}{r}8.5 \\
11.3 \\
-2.8\end{array}$ \\
\hline $\begin{array}{l}\text { hange in deht-10-GDP ratio } 2 / \\
\text { Primary balance effoct } \\
\text { Grants effect } \\
\text { Interest-outp. diff. effect } \\
\text { Exchange rate effect }\end{array}$ & $\begin{array}{r}2.5 \\
-30.7 \\
15.9 \\
-12.5 \\
-0.2\end{array}$ & $\begin{array}{r}-3.4 \\
-23.1 \\
17.7 \\
-8.8 \\
0.0\end{array}$ & $\begin{array}{r}1.0 \\
-10.9 \\
13.0 \\
3.1 \\
0.0\end{array}$ & $\begin{array}{r}39.2 \\
-10.4 \\
8.6 \\
5.4 \\
-31.9\end{array}$ & $\begin{array}{r}30.5 \\
-12.4 \\
12.8 \\
5.2 \\
-25.7\end{array}$ & $\begin{array}{r}0.9 \\
-4.7 \\
10.9 \\
-3.6 \\
-10.7\end{array}$ & $\begin{array}{r}-1.1 \\
-3.1 \\
8.7 \\
2.3 \\
-2.2\end{array}$ & $\begin{array}{r}-24.7 \\
5.5 \\
3.9 \\
-13.8 \\
1.5\end{array}$ & $\begin{array}{r}-6.4 \\
0.2 \\
4.1 \\
-3.6 \\
-1.5\end{array}$ & $\begin{array}{r}-1.0 \\
-0.9 \\
3.4 \\
-3.0 \\
-4.6\end{array}$ & $\begin{array}{r}2.1 \\
-17.8 \\
12.6 \\
-5.4 \\
-2.3\end{array}$ & $\begin{array}{r}-0.3 \\
-2.6 \\
7.3 \\
-2.8 \\
-7.2\end{array}$ \\
\hline
\end{tabular}

i/ Re:onstructad frum 1989 dehe figure, annual deficits. and exchange rate effoct.

I Excluding net lending und extrabudgetary expenditure.

iNegative if deprocintion. 
fiscal deficit (excluding foreign grants $2 /$ ) of 20 percent of GDP during 1975-88, 17.6 percent of GDP was attributable to structural primary deficit (Table 9, Charts 15 and 16). The injection of expansionary stimulus was particularly strong up to 1980, and declined substantially during early 1980s. In response to rapid accumulation of debt burden and external financing constraints, the authorities started to tighten the stance of fiscal policy by mid-1980s, and the fiscal impulse accordingly turned significantly contractionary from mid-1980s. Interest payments on the outstanding public debt was low (at around 1 percent of GDP) during the 1970s, increased significantly in the 1980s in line with the growing debt burden, accounting for 7 percent of GDP by 1988 and 10 percent of GDP by the end of the decade. Based on these considerations, the observed deterioration in the fiscal position between 1985 and 1988 was not the result of discretionary fiscal policy, but of the continued large structural primary deficit, economic slowdown, and markedly higher interest charges.

The same budget identities can be used to measure the primary balance required to stablilze the ratio of public debt to GDP and to compare it with the observed primary balance. Stability of the debt-to-GDP ratio will be achieved if the primary surplus in percentage of GDP is as follows:

$$
\begin{aligned}
\mathrm{PB}_{t} / Y_{t}- & \left(\left(I_{t}-\mathrm{B}_{t}\right) /\left(1+\mathrm{g}_{t}\right)\right) \cdot \mathrm{D}_{t-1} / \mathrm{Y}_{t-1} \\
& +\left(\mathrm{FD}_{t-1} / \mathrm{Y}_{t-1}\right) \cdot\left(1 /\left(1+\mathrm{B}_{t}\right)\right) \cdot\left(\left(\mathrm{ER}_{t-1} / \mathrm{ER}_{t}\right)-1\right)
\end{aligned}
$$

Assuming no exchange rate effect on the valuation of the outstanding stock of foreign debt, the required prinary balance will depend on the differential between the implicit interest rate on public debt and the growth rate, both in nominal term, and the current debt ratio. If the differential is positive, stabilization of the debt-to-GDP ratio requires a primary surplus, whose magnitude is proportional to last year's debt-to-GDP ratio and to the size of this differential. On the other hand, if the differential is negative, stabilization can be achieved even with some primary deficit.

1 Grants, seen as a financing item, are excluded from total revenue. This can blas the fiscal balance downards, given that part of the grants have financed expenditure, in particular capital expenditure, that would not have taken place otherwise. On the other hand, extrabudgetary operations are excluded, given that no information prior to 1985 is available. In addition, net lending is also excluded. 


\section{CHART 15 \\ JORDAN \\ EVOLUTION OF DEBT TO GDP RATIO, 1975-94}

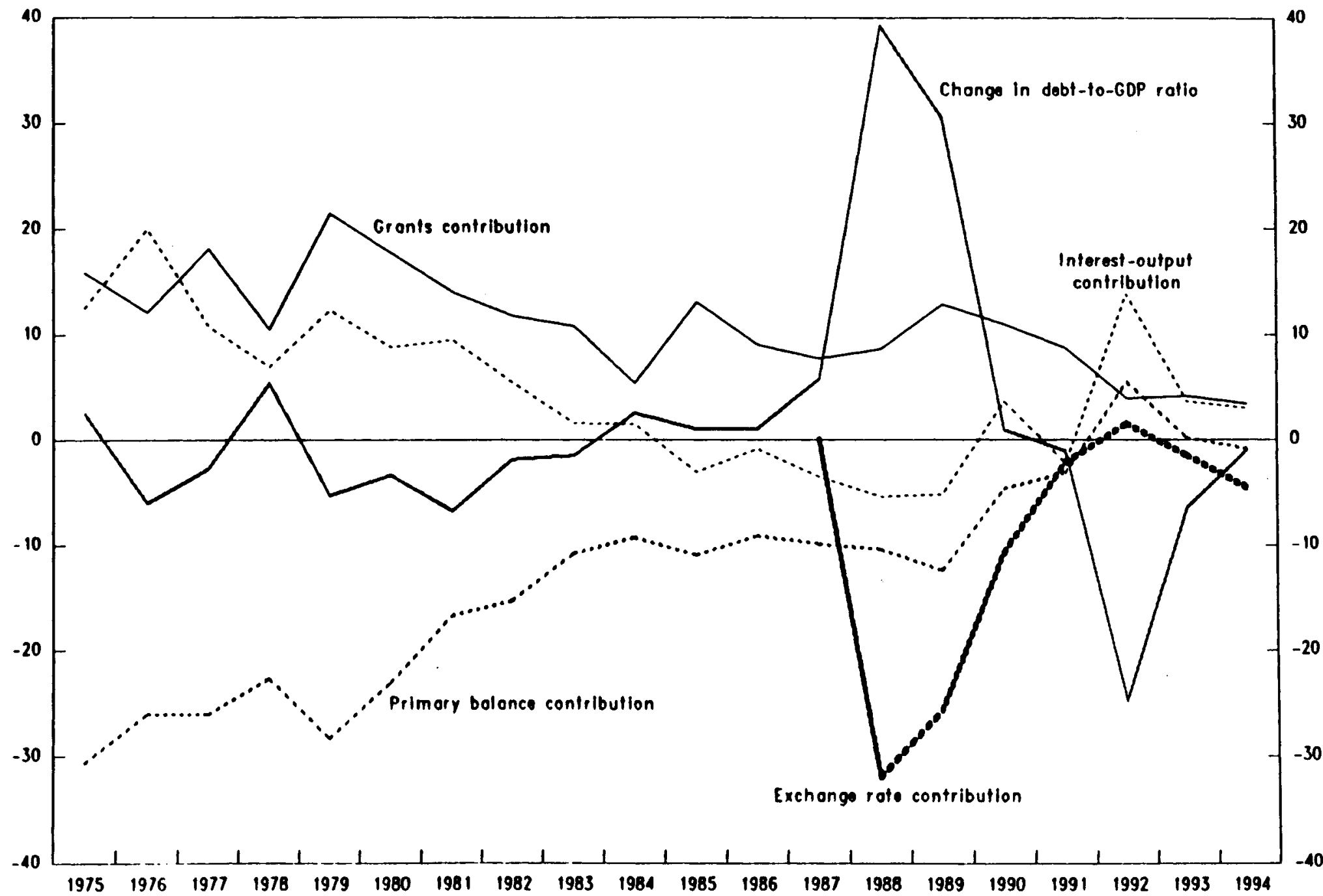

Sources: IMF, Internotional financial Statistics, and vorlous Recent Economic Dovelopment Reports. 


\section{CHART 16 \\ JORDAN \\ FISCAL IMPULSE BREAKDOWN, 1975-94 1/}

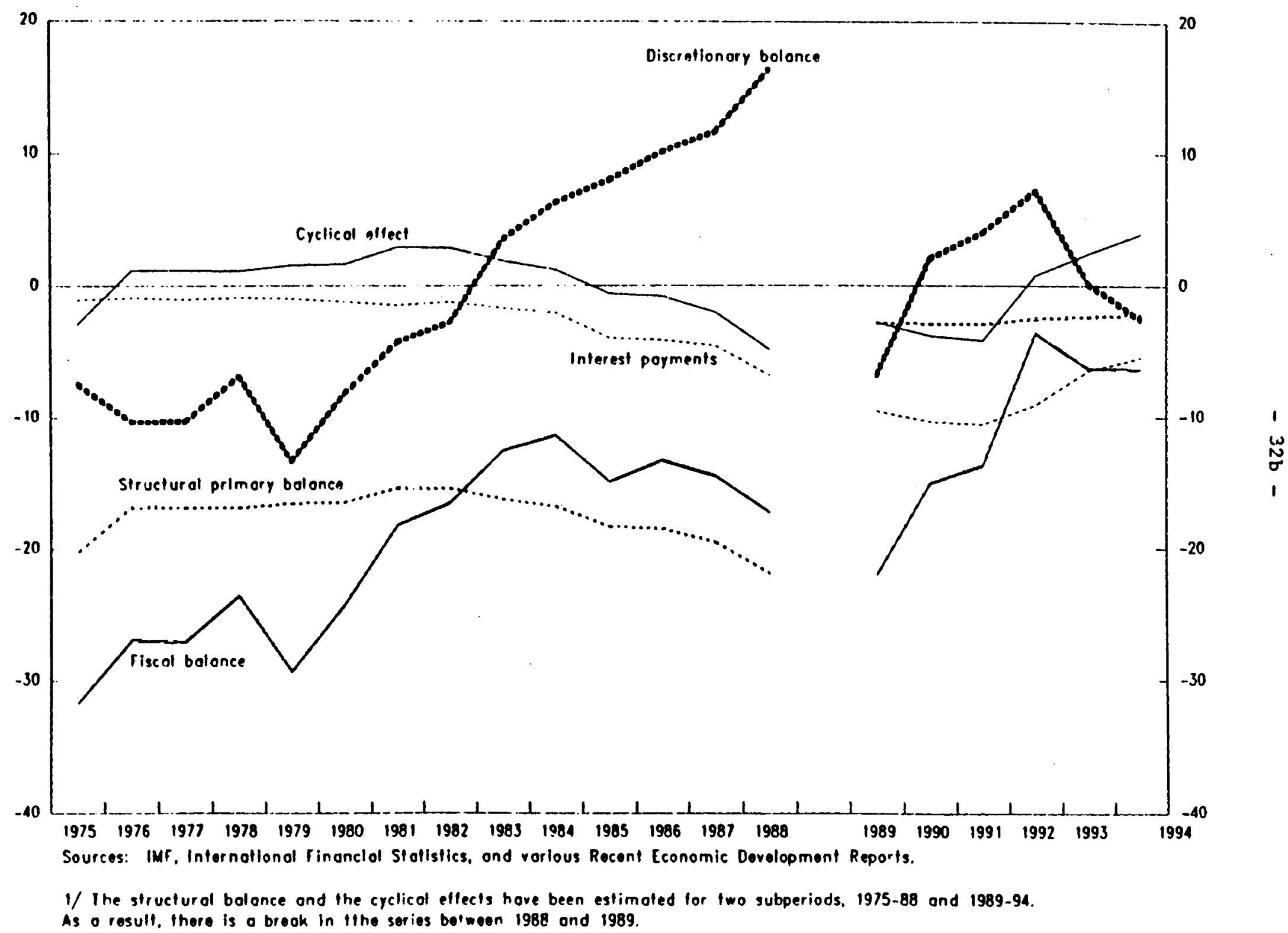

CInternational Monetary Fund. Not for Redistribution 


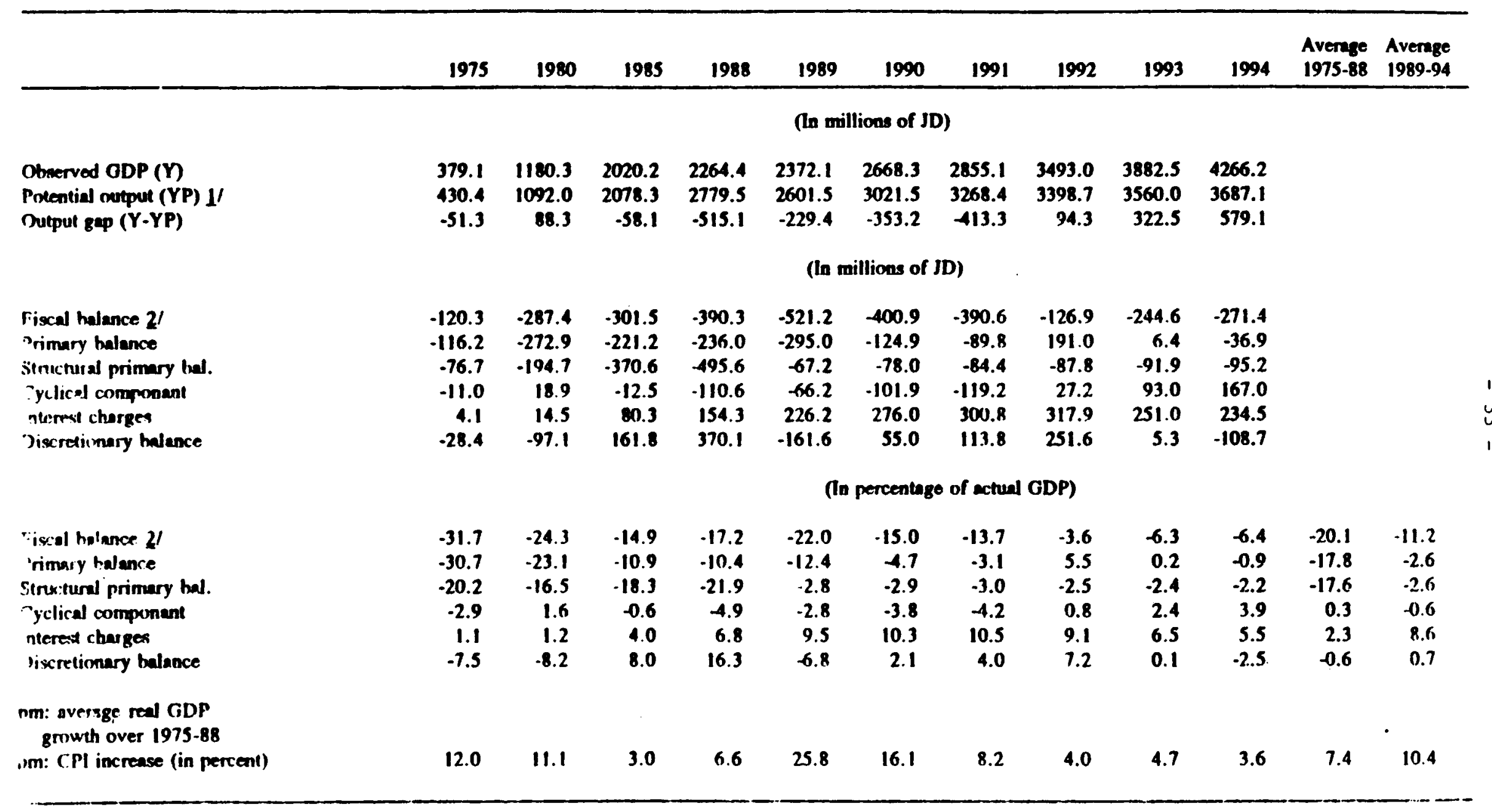

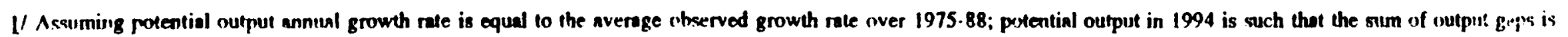
ro.

2/ Excluding net lending, extrabudgetary expenditure, and grants. 
In Jordan, the implicit interest rate has increased sharply during the 1980s. This can be explained by a substantial shift in the composition of foreign debt over the period toward debt on commercial terms. I/ In 1980 , over 80 percent of the outstanding external debt was owed to official bilateral creditors, most of which on concessional terms. The share of external public debt owed to foreign banks and commercial companies increased from 7 percent in 1980 to 20 percent in 1988, as the availability of funds on more attractive terms from official creditors fell short of the financing needs of the Govermment. On the other hand, Interest rates on domestic debt were broadly stable.

The differential between implicit interest rate and growth rate was negative in the 1970 s and through 1984 (Chart 17). Simultaneously, although actual primary deficit remained high, it declined steadily through 1984 and remained stable thereafter through 1988. The combination of those two factors led to a contraction of the debt-to-GDP ratio between 1979 and 1983 and a steady increase from 1984 onwards. In 1988, the debt-to-GDP ratio jumped by 36 percentage points to 95 percent of GDP. The dramatic exchange rate adjustment that took place in 1988 explained about 80 percent of the increase in the debt ratio in 1988.

\section{Shift in fiscal policy stance (1989-94)}

The Government drastically shifted the stance of fiscal policy beginning in 1989--in the context of Fund supported adjustment programs.which contributed to a reduction in the central government's fiscal deficit, excluding foreign grants, by almost 18 percentage points to 5.9 percent of GDP in 1994. Two-thirds of the fiscal consolidation were attributable to expenditure restraint and the remainder to revenue increase. Central government finances started to lmprove in 1989, as adjustment policies including discretionary fiscal measures were implenented. Despite the adverse effects of the $1990 \mathrm{reg}$ ional crisis, which depressed the econonic activity and increased pressures on public services and social expenditure programs, the flscal deficit was reduced further in 1990 and 1991 . In response to a strong economic rebound and adoption of sizable discretionary revenue measures, public flnances improved dramatically in 1992; the underlying fiscal deficit (excluding forelgn grants) declined to about 7 percent of GDP, and accounting for nonrecurrent revenue gains ( 3.5 percent of GDP) --in particular the customs duty on cars Imported by the Jordanians returning from abroad--the deficit decreased even further. Fiscal consolidation continued during 1993, albeit at a much slower pace.

1 Some exceptional factors have disturbed the time series for interest charges. For instance, in 1985, Interest payments included JD 10 million of interest obligations due by public enterprises which the Central Government assumed, boosting the average interest rate by more than 1 percentage point in relation to GDP. 


\section{CHART 17 \\ JORDAN}

IMPLICIT INTEREST RATE AND ECONOMIC GROWTH RATE, 1975-94

(Percentage chonges)

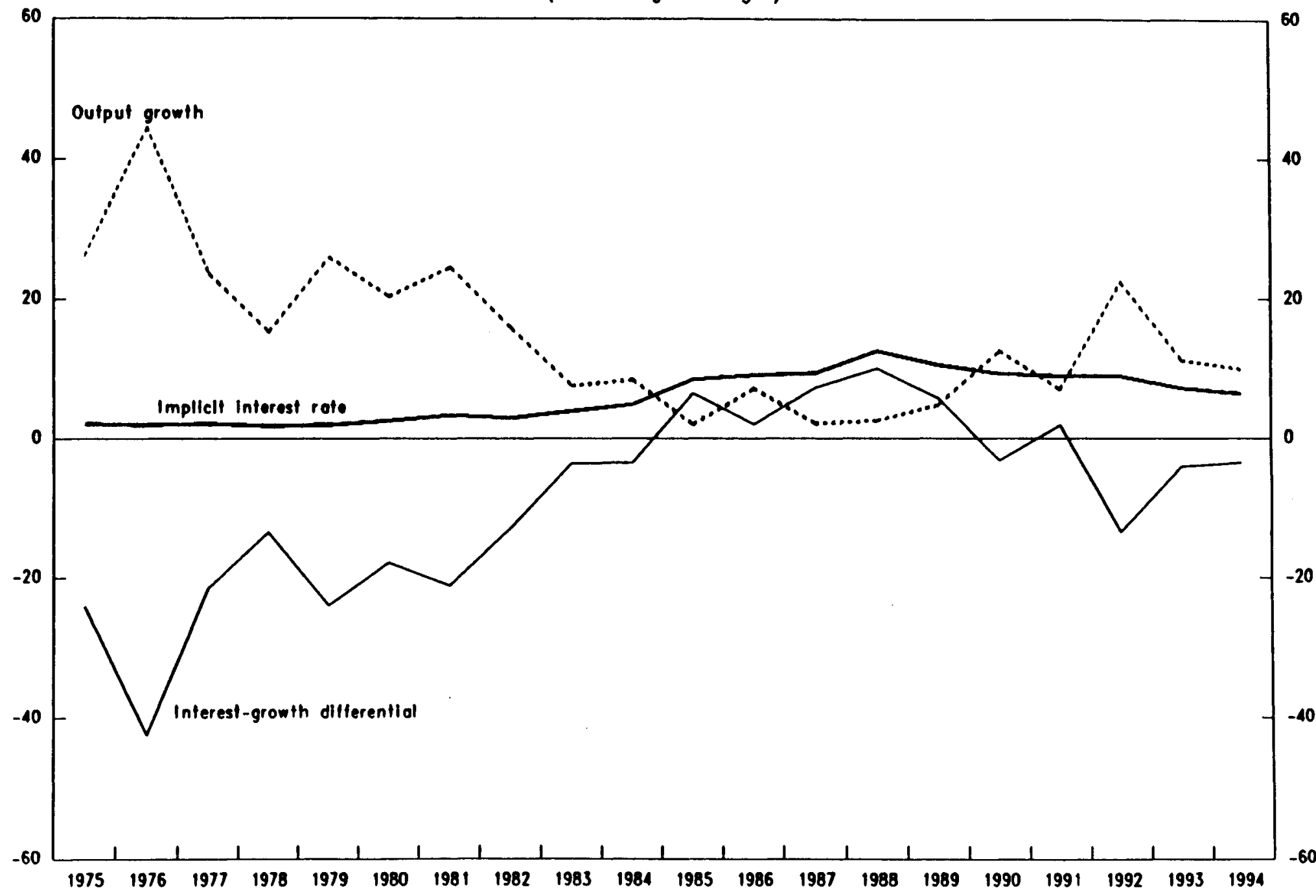

Sources: IMF, Internotional finonclol Statistles, ond varlous Recent Economic Development Reports. 
This page intentionally left blank 
Reflecting the discontinuation of grants from most regional courtries in the aftermath of the regional crisis, foreign grants declineo by 5 percentage points since 1988 to 3.4 percent of GDP in 1994. As a proportion of total central government recelpts, grants decreased from 26 percent in 1988 to 10 percent in 1994.

\section{a. Debt dynamics and sustainability of the debt ratio}

The evolution of the debt-to-GDP ratio largely mirrores the fiscai consolidation process started since 1989. The debt ratio on account of central government operations, wich peaked in 1990 at 126 percent of GD? as a result of the exchange rate depreciation, declined sharply in 1992, and at a slower pace thereafter. A reversal in the interest-output differential which turned significantly negative since 1992 contributed to the observed debt reduction.

In response to the Government's discretionary fiscal measures, primary fiscal balance sharply improved beginning in 1990 and became significantiy positive in 1992 reflecting strong fiscal efforts and economic growth, and the effect of some favorable transitory factors (see below). Overall, the primary fiscal deficit almost vanished coupared with an average of 21 percent of GDP recorded during the period through 1988. Despite tigine: interest rates, the differential between the average interest rate and nominal output became negative every year except 1991 when output growth was sharply lower in the aftermath of the 1990 reglonal crisis. The significant improvement in the debt ratio occurred despite a substantial reduction in the inflow of foreign grants and the adverse effects originating frud exchange rate depreciations in 1993 and 1994, as the JD was de facto pegged to the U.S. dollar. $1 /$ Foreign grants steadily declined from about 13 percent of GDP in 1989 to 3 percent in 1994 since traditional sources virtually stopped providing grants to Jordan after the regionel crisis.

Overall, the tumaround toward a primary budget balance and the negative interest-output differential both indicated that since 1990, wit: the fundamental shift in the stance of fiscal policy, the dyramics of the debt ratio became sustainable and exhlbited a marked declining irend. Fne structural improvement in the primary balance was attributable to favcrable developments in revenue and expenditure reflecting efforts to 1mprove elasticity of the tax system, broaden the tax base and to contain recur: : : outlays.

\section{b. Revenue mobilizetion}

Total revenue increased from 24 percent of GDP in 1988 to almost 30 percent in 1994, with ta: revenue increasing by 5 percentage points (Chart 18). The inc: iase essentially reflected frequent discretionary

1) In this section, grants are considered as a separate factor in debt dynamics. 
revenue-ralsing measures, as the structure of the tax system remained inelastic with respect to incone. The revenue structure, however, has 1mproved, with a decline in relative terms of taxes on forelgn trade and the administrative procedures for collecting taxes and arrears have been tightened. Recelpts from post and telephone services and profits fron the centrel bank were the nost buoyant nontax revenue sources.

\section{(1) Taxes on forefon trade}

Besides the positive effects of the 1988 and 1989 exchange rate depreclation on the value of imports, the increase of receipts from customs duties resulted from higher inport volune, despite the depreciation, in connection with the acceleration in the pace of econonic activity and a tariff reform. Collection of Import taxes was also boosted in the early 1990 s by shift in the composition of imports in favor of consumer durable goods on which higher duty rates were levied. This shift was associated wh the reflux of Jordanians from nelghboring countries in the aftermath of the regional crisis. In addition, a temporary duty was levied on the returnees" cars from November 1991 to December 1992, boosting revenues by about 2 percentage points of GDP. Another factor behind the revenue increase was the renoval, effective January 1990, of the ban on imports of some high-duty luxury Itens that was Imposed in November 1988.

While maintaining its efforts on revenue nobilization, the Government also launched in 1989 a gradual tariff reform ained at a lower, nore uniform and nondiscriminatory structure of protection anong economic sectors. As part of this reform. the aximum cumulacive inport tax rate, was reduced to 50 percent from more than 300 percent for all nonluxury imported goods. At the same time, however, to reduce the revenue effect of this reform. the aininum effective tariff rate was increased by levying the additional tax at a 5 percent rate, Instead of the standard 3 percent rate, on imports which were exempted fron other Import taxes.

The Government launched a second round of tariff reform in Novenber 1994. Custons tariff rates on a linited range of products, in particular. in :he transportation sector (new and used cars, trucks, and spare parts) were reduced. For new cars, the tariff range was lowered from $125-320$ percent to $70-200$ percent; for used cars, the tarlff range was lowered from 115-310 percent to about 50-150 percent. The ban on Imports of used cars of wore than five years have been maintained for environmental and other considerations. Trucks, for which duties varied from 15 to 30 percent, are now exerfyted. Customs duty on spare parts was decreased from 30 percent to 10 percent. As a result of the varlous trade reforns undertaken in recent yesrs, the aximue custom rariff rate 18 now 50 percent (except for cars. clgarettes, and alcoholic beverages).

\section{(2) Taxes on domestlc transactions}

Between 1988 and 1994 , the revenue of taxes on domestic transactions as a proportion of GDP increased from 3.5 percent to 


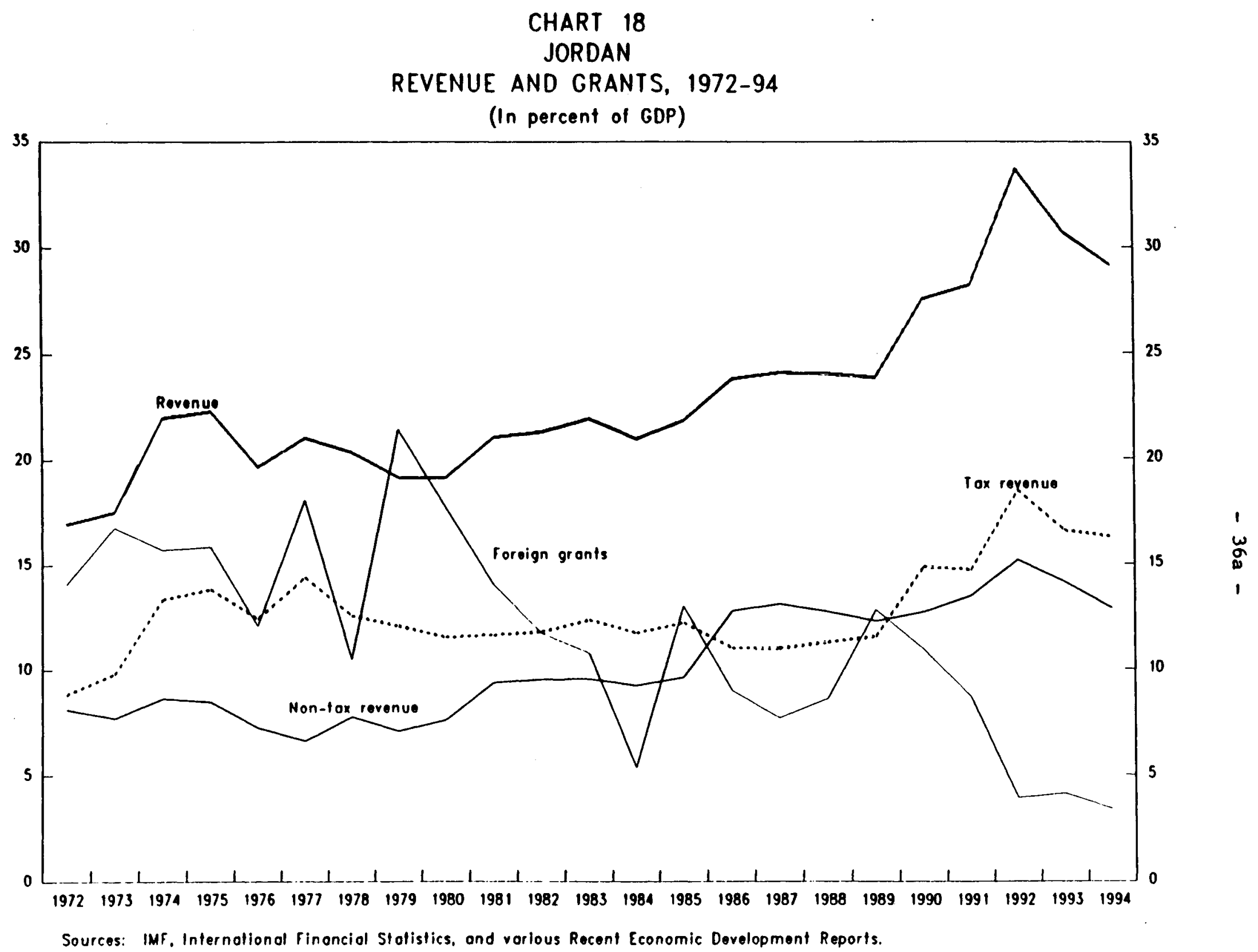

CInternational Monetary Fund. Not for Redistribution 
This page intentionally left blank 
6.4 percent. While snnual nominal growth rate of GDP averaged 11 percent over the period, revenue from these taxes increased by 23 percent on average.

Revenue from the consumption tax and excise duties, consolidated under the Consumption Tax Law of November 1988, almost doubled between 1988 and 1994, reflecting several increases in tax rates and extensions of the coverage of goods subject to taxation. The total yield of other taxes on domestic transactions, although of limited magnitude, grew rapidly over the same period, as a result of increases in the property transfer tax rate and higher departure fees.

The coverage of the consuaption tax was broadened in 1992, and with a further addition of 21 itens in June 1993, the total number of items subject to the consumption tax rose to 106. In addition, the existing consumption tax on certain imported 1 tens was extended to their equivalent produced domestically and certain specific rates were converted into ad-valorem rates. Despite the coverage extension, the current structure of consumption tax remained heavily concentrated on a few products. Excises on cigarettes alone accounted for 44 percent of consumption tax receipts in 1992. Together with cement, soft drinks, steel bars, and lubricating oil, this share increased to 80 percent.

With a viow to broaden the domestic tax base and making the tax system more elastic and more efficient, the authorities replaced the consumption tax by a GST on June 1, 1994. The GST is levied on all Imports and on manufactured goods and on some services produced or rendered locally by providers with annual sales above a given threshold (JD 200,000). Wholesale and retail levels are excluded.

The standard ad valorem rate is 7 percent. A 20 percent rate is levied on a limited number of goods (such as perfume and electric appliances). Specific rates continue to be levied on tobacco products, alcoholic beverages, soft drinks, cenent, and few other products. Exports are zero rated. However, there is scope for further significant widening of the GST base since urany goods are still exempted; In some instances the exemptions are restricteo only to locally produced goods (such as clothes, shoes, and furniture). The credit mechanism is also somewhat restricted in the sense that it is limited to only embodied inputs.

\section{(3) Taxes on income and profits}

Receipts from personal and corporate income taxes, which were below 2 percent of GDP in 1988, increased to 3.2 percent of GDP by 1994 . In 1994, about 60 percent of direct taxes were collected from corporations, with individuals (partnerships and professionals) contributing 25 percent and salaried employees 15 percent. Dividends, interest, and capital gains were tax exempt. 
Although the tax base was somewhat broadened by reducing both exemptions and deductions in November 1989, the personal income tax remainec characterized by numerous exclusions of income from tax and liberal exemptions, with the effect that relatively few individuals were actually subject to income taxation. There were ten income tax brackets and the top marginal tax rate was 45 percent. There were five different corporate tax rates based on the nature of activity (industrial, financial, other) and ownership (public, private).

\section{(4) Nontax revenue}

Nontax revenue as a proportion of GDP remained broadly stable at about 13 percent of GDP during 1988-94. Fees, licenses, and charges for government services were increased substantially in 1986 and again in the three subsequent years. A royalty tax on phosphate and potash production was introduced in 1989. The operating surpluses from post and telephone services expanded continuously since 1988 because of increased coverage and rate increases.

\section{c. Expenditure}

During 1989-94 the average increase in central government expenditure and net lending was $l$ imited to 5.7 percent, and accordingly, total expenditure as a proportion of GDP declined by 12 percentage points to 35 percent in 1994 . This reduction was achieved notwithstanding strong pressures on expenditures from several sources. In particular. the exchange rate adjustments during 1988-89 led to the subsidization of food staples and higher interest payments on foreign debt, and the 1990 regional crisis had led to strong pressures on recurrent expenditures. Supplementary expenditures had to be incurred during 1990.91 reflecting the needs of the large number of Jordanian workers returning from neighboring countries (especially for housing and education, emergency stockpiling of food supplies) and increased military preparedness. However, the authorities succeeded in accommodating these pressures without significantly hindering the ongoing expenditure containment efforts. Extrabudgetary expenditure vanished, positive net lending became negative, and both current and capital expenditure decreased as a proportion of GDP. 1

Since 1992, current expenditure has been fully covered by total domestic revenue, whereas a significant shortfall existed in the late 1980 s. Progress in expenditure quality, however, has been mixed. Military outlays have been reduced by about 3 percentage points of GDP, and food subsidies, after a sharp increase in the aftermath of the exchange rate adjustments, have been on a declining trend. Gross lending to public enterprises and decentralized agencies was significantly curtailed. Capital monditures

I/ Until 1991, total expenditure included extrabudgetary expenditure, of an unknown nature, defined as the difference between the financing available to the Treasury and the recorded cash deficit. 
have been reduced as a proportion of GDP, but the lower level--at 6.4 percent of GDP in 1994--may be nore in line with absorption capacity of the Jordan economy. On the other hand, the wage bill has increased from 6.5 percent in 1988 to 6.9 percent in 1994 and the share of public pensions in total outlays has also increased significantly.

Wages and salaries, which is the largest component of civilian expenditure, currently amount to alnost 7 percent of GDP. Between 1991 and 1994, civilian employeent has increased by 15 percent to reach 118,500 units. Over the same period, the total wage bill has increased by almost 60 percent in nominal terms and by 40 percent in real terms. In 1994 , civilian employment increased by about 3000 units, while the total civilian wage bill, excluding pensions, increased by 20 percent in nominal terms. 1

Pension outlays for both civil servants and military personnel increased by 1 percentage point of GDP between 1988 and 1994 as both the number of beneficiaries and the average pension increased. Long-term sustainability of pension arrangement also remains questionable. 2/

\section{Forthcoming structural reforms in the fiscal area}

The current level of total domestic revenue in relation to GDP (almost 30 percent) is broadly satisfactory, and is comparatively high among developing countries at about the same level of development. There is a need, however, for further decisive efforts to enhance revenue elasticity and efficiency of the tax system and reduce dependence on nontax revenues. Additional structural improvements in the tax system would help avold the need for frequent and politically difficult discretionary revenue measures due to the inelasticity of the existing tax system. They would also help

1 In addition to automatic cost-of-living adjustment and seniority wage increases, general wage increases have been granted in 1992, 1993 and 1994. while no wage increase had been granted between 1986 and 1991 despite the devaluation of 1988-89. In April 1993, the Government decided to increase all wages (and pensions), including those of military and security personne1, by JD 15 per month with retroactive effect to January 1, 1993. In 1993, specific wage increases had also been committed for some departments and employment categories. Effective on July 1, 1994, another general wage increase was granted. The increase, under the form of allowance, is equivalent to 10 percent of the basic salary, excluding allowances, with a minimum of JD 10 per month.

2) Public pensions are unfunded and the ratio of payments to contributions is above 8 . Benefit formula is based on last salary, excluding allowances, increased by 25 percent, with an adjustment coefficient to reflect the duration of employment. The coefficient is the number of years divided by 40 ( 30 for military personnel). Pensions are supplemented with cost of living allowances and family allowances. Contributions are equivalent to 8.75 percent of basic salary. 
reorlent the tax system to the changing structure of the economy from an import-based to a broader domestic consumption-based system. On the expenditure front, the key areas where further action is needed are contalment of the civilian and military wage bill (including pension liablifties) and food subsidies. Key policy actions which are under consideration include:

\section{a. Reform of the GST system}

The authorities have stated their intention to amend the GST law. The major features under consideration are to: (1) increase the standard rate to 10 percent; (11) replace the positive list of services subject to taxation by negative list with limited exemptions; (iii) allow for voluntary registration of taxpayers; (iv) include provisions for introducing supplementary duty on selected luxury or soclally undesirable products in order to protect revenue in the context of the next stage of external tariff reform.

\section{b. Tariff reform}

The next stage of external tariff reform aims at: simplification of the customs tariff structure by combining the existing numerous fees and charges into one consolidated tariff structure; a significant reduction of the number of tariff rates; reduction of nontariff barriers through elimination of import licensing requirements and import monopolies; and a further reduction of the maximum consolidated tariff rate to 50 percent. The intended introduction of supplementary (excise) duties within the GST framework will pave the way for reducing maximum duties without reducing tax revenue. Such supplementary tax should be applied equally on both domestic and imported goods and Imposed on a limited range of Items selected on the basis of equity, health, and enviromental considerations.

\section{c. Income taxation}

The authorities intend to Introduce shortly a new income tax law. Regarding corporate profits tax, the major changes would be as follows: (1) elinination of tax holidays (except for investments in less developed areas): (11) limitation of interest payments deductibility to interest payments net of interest earned; (111) introduction of a 10 percent withholding tax on cash dividends; and, (iv) rationalization of corporate income tax rates with a view to treating all corporate sectors equally and reducing the standard corporate incone tax rate to the level of the maximum tax rate for personal income, 1.e., 30 percent. In addition, state-owned enterprises, which are currently exempted, could in the future be included under the tax base by decisions of the Council of Ministers on a case by case basis. Instead of tax holidays, companies benefiting from the investment law, will enjoy a 15 percent corporate tax rate. 
Regarding the personal incone tax reform, proposed major changes are: (1) the reduction of the number of tax rates (from 10 to 6 rates); (1i) the reduction of the maximum rate from 45 percent to 30 percent; and, (iii) replacement of the current practice of property tax set-off against income tax by making property taxes deductible against taxable income.

\section{d. Food subsidies}

Better targeting, cross-subsidization, higher cost-recovery rate for subsidized prices and complete elimination of sone subsidies, in combination with favorable international commodity price developments, contributed to lower the budgetary cost of subsidies from 3.3 percent of GDP in 1990 to 1.0 percent in 1994. However, generalized price subsidies persisted for wheat and the targeting of means-tested subsidies needs to be improved. A significant increase in comnodity prices combined with the steady population growth rate, could jeopardize the savings achieved between 1990 and 1994. The authorities are thus considering a fundamental reform of the current generalized food subsidy program by charging the full price to consumers, while protecting the low-income households through direct cash transfers based on family income. Such a schene could be established by end-1995, and should enable the Government to generate net budgetary savings (about 0.5 percent of GDP, based on current costs) and also prevent waste and smuggling of the subsidized products.

\section{v. Einancial Liberalization and Monetary Reforms}

Jordan's financlal system has expanded greatly over the last two decades--desplte passing through a turbulent period during the late $1980 \mathrm{s.-}$ with the ratio of money and quasi-money to GDP increasing from 60 percent in 1970 to over 100 percent in the late 1980s. Like the rest of the economy, the financial system in Jordan was adversely affected by the balance of payments and the financial crisis of the late 1980s, and it strengthened thereafter significantly with the implementation of structural reforms, a general rebounding of economic activities since 1992, and increased profitability of the commercial banks. Although the financial system is deeper than before, like many other developing countries, it has a long way to go before it becones sufficiently well developed: the system is dominated by a small group of domestic banks; the variety of financial instruments for users and providers of funds is rather limited; the capital market--with the exception of the stock market--is extremely thin. In general, the financlal system faces the challenging task of funding the most efficient investments while managing the risks and integrating with the world financial markets. 


\section{Historical background and developments (1970-94)}

\section{a. A rapid expansion of the financial system $1970-94$}

In 1970, the Jordanian banking system was poorly developed and comprised eight commercial banks, of which four were branches of foreign banks. The largest domestic bank and the largest foreign bank (Grindlays Bank Ltd.) If accounted for half the total branches of domestic and foreign banks in Jordan, respectively. Twenty years later, the number of banks has increased threefold $2 /$ and the total number of branches spread all over the country increased from 41 to more than 300 (Box 1). The deepening of the financial system during these two decades encompassed many areas, including enhancement of banking intermediation, improvement of the payment system, and establishment of an active stock exchange.

The banking system played an effective role in intermediating shortterm savings and long-term financing requirements. 3 Total outstanding credit facilities of commercial banks increased from 20 percent of GDP in 1970 to more than 60 percent of GDP in 1994, reflecting a deepening of private sector financing. Simultaneously, the role of the specialized credit institutions as major intermediating institutions expanded considerably. Their total loans and advances to the private and public sectors stood at 20 percent of GDP in 1993, compared with less than 7 percent of GDP in the early 1970s.

The payments system also improved dramatically, with the commercial banks clearing operations reaching 7.2 million checks in 1993 compared with less than 500,000 in 1970 . The shift from cash holdings roward time and savings deposits was reflected in an unprecedented growth of resident deposits in the banking system, which increased from 20 percent of GDP in 1970 to about 90 percent of GDP in 1993 (Chart 19). This rapid monetization of the economy has resulted in a downward trend in the income velocity of money during the 1980s (Appendix II).

1/ Established in 1927 as the Otcoman Bank which became Grindlays Bank in 1969.

2/ The banking system in Jordan consists of the $C B J$, six foreign commercial banks, sixteen domestic commercial banks (of which one operates on the basis of Islamic financial principles), seven financial institutions, and a number of non-deposit-taking financial institutions which includes. inter alia, the Social Security Corporation and eighteen insurance companies.

3) Traditionally, the financial depth of an economy is measured through the ratio of liquid liabilities to GDP, assuming that the size of the financial intermediary sector is positively correlated with the provision of financial services. Total liquid liabilities of the financial system may be proxied by the ratio of money and quasi-money to GDP. In the case of Jordan, this ratio has doubled since 1970 to reach 125 percent in 1993. 
$-42 a-$

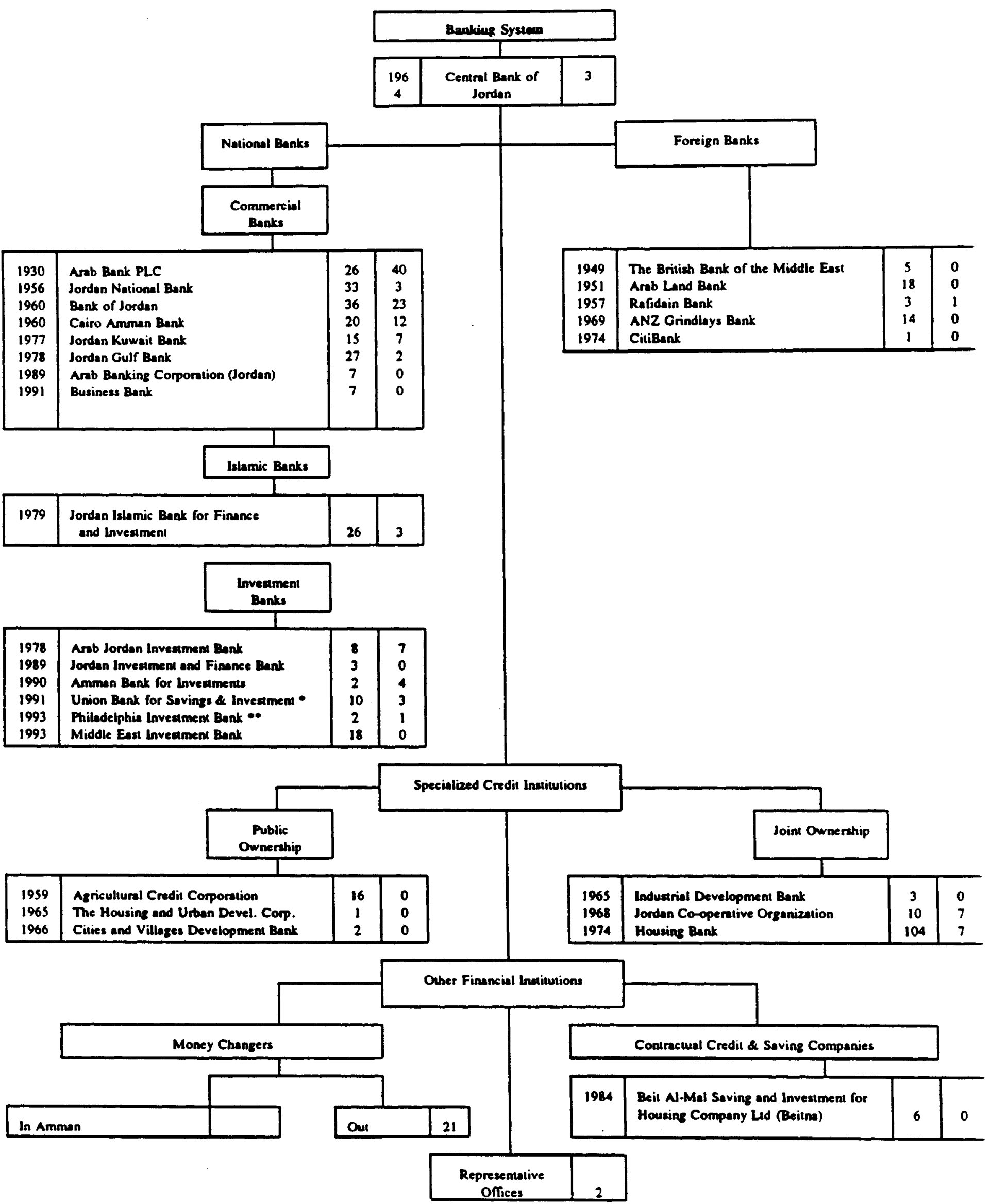

- Resulied from the merger of DARCO company and Jordan Finance House.

- Previously known as REFCO. 
CHART 19

JORDAN

MONETARY AGGREGATES, 1970-94

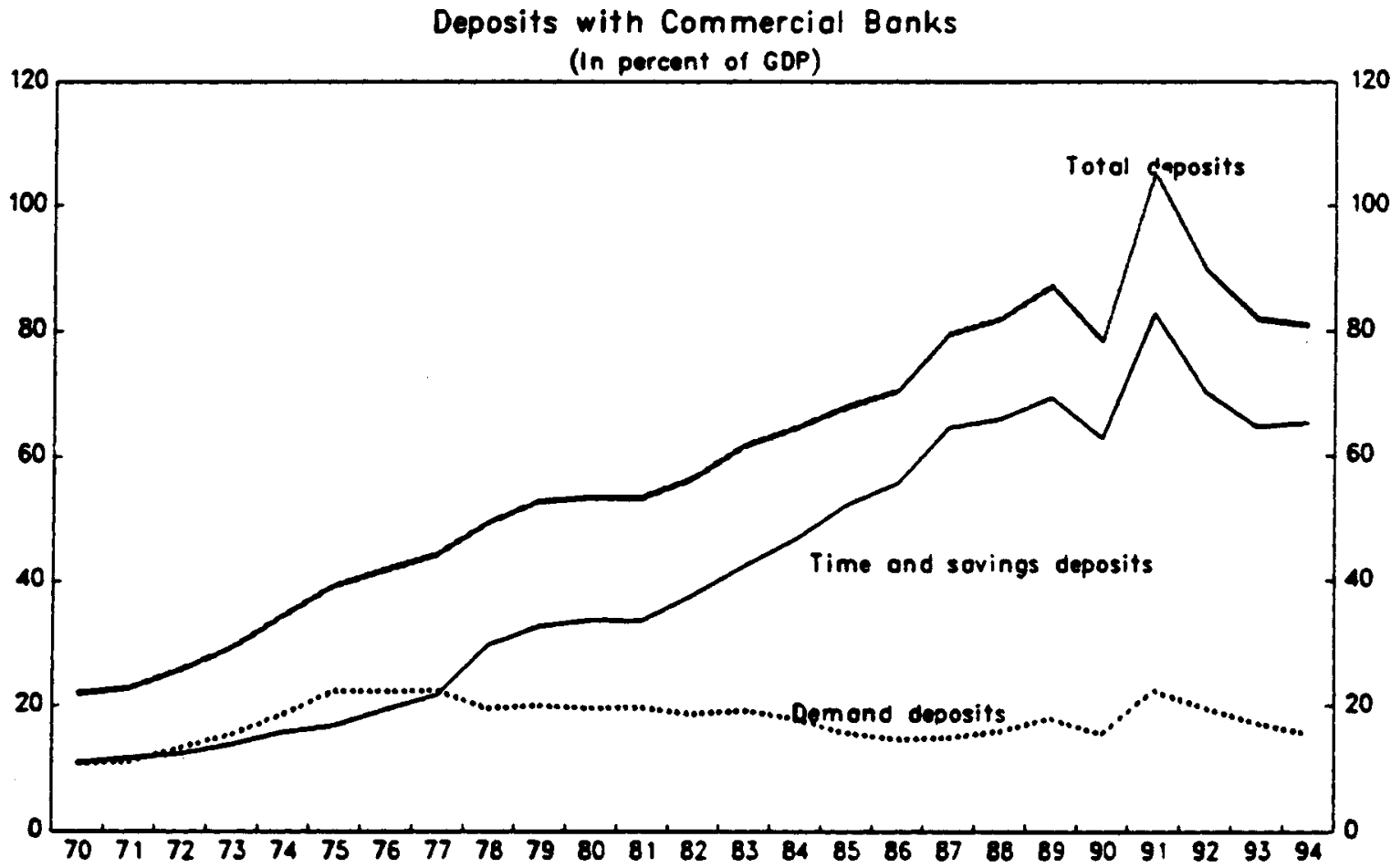

Domestic Credit

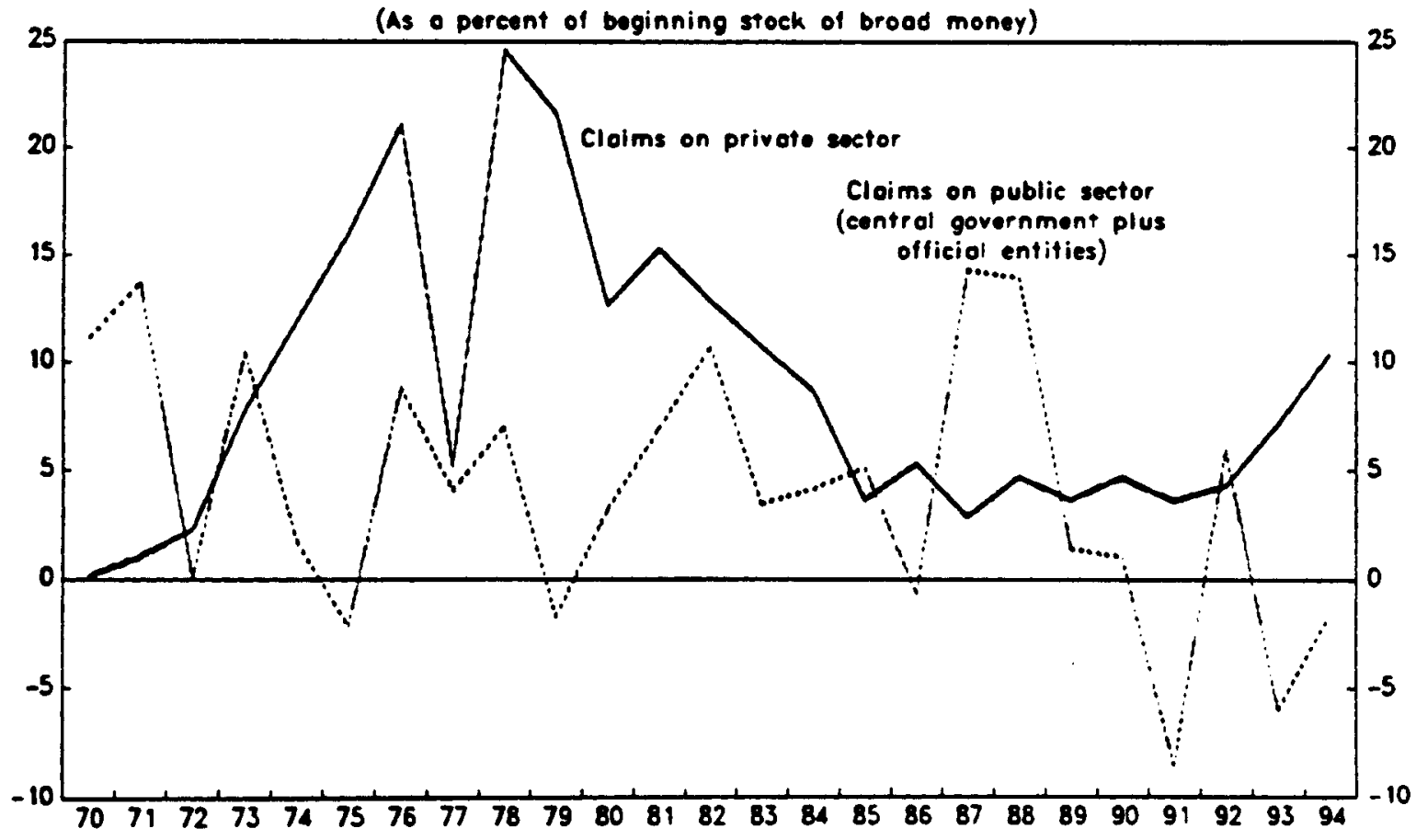

Source: Deportment of Statistics. Government of Jordan; Central Bank of Jordan. 
Perfornance of the financial system was further enhanced by the establishment of the Aman Financial Market (AFY) for trading in securities in 1976. Since its creation, the AFY recorded a sustained and rapid expansion of its operations, which ade it one of the nost active emerging markets in the Middle East. Instruments traded on the stock exchange include private corporate equities and bonds, Jordanian government bonds and treasury bills, and development bonds. The bull or bear markets of the 1980 s were determined by the developments in workers' remlttances (which were closely correlated with novenents in the international oil prices). The impressive performance of the API was also attributable to the fact that the AFY did not have to compete in an environment of perverse yield curve such as rates of return on fixed interest daposits well in excess of the rate of inflation, resulting from government interventions. The market capitalization stood at US\$4.7 billion as of end-December 1994 and the number of shares traded in 1994 amounted to 134 million for a total value of US\$620 million.

\section{Operation of monetary policy, $1970-88$}

\section{a. Monetary developments}

Jordan's inflation during the 1970 s and through the late 1980s was generally low, reflecting in part a prudent stance of monetary policy. 1 / Money and quas 1 money expanded at an annual average rate of 18 percent during 1970-88 mainly as a result of the expansion in net donestic assets which increased by 14 percent (as a percentage of the beginning period stock of broad money) on average during the perlod. By contrast, the rate of expansion in net foreign assets was linited at 4 percent on average during 1970-88. The bulk of the donestic liquidity expansion took the form of credit to the private sector which rose by about 10 percent on average during the period. Borrowing by the central government and the public entities remained relatively sall, rising on average by 6 percent annually during 1970-88. However, a shift took place, beginning in the early 1980s, in the relative composition of the donestic credit expansion. The rapid expansion in claims on the private sector started to moderate in 1979, and decelerated from about 25 percent (as a percentage of the beginning period stock of broad money) to 2.8 percent in 1987, whereas credit to the public sector started to rise at a double digit rate.

\section{b. Public sector driven credit expansion}

The fiscal policy stance since the mid-1980s resulted in a rapid deterioration of public finances in 1987-88. As recelpts of foreign grants declined steadily. recourse to donestic bank borrowing increased sharply. During 1987-89, the annual rate of expansion of broad money (money and quasi money) averaged 13 percent, at a time when the real economy was stagnant or

1 The average rate of inflation was contained at around 6 percent during the decade through the late 1980s. 
in recession. Given the decline of net foreign assets (NFA) in 1987-88, the increase in broad noney supply was essentially due to a sharper expansion in the NDA. In particular, clains on government increased by 130 percent and 50 percent in 1987 and 1988, respectively. Donestic bank borrowing by the public sector enterprises also increased in the wake of growing financial difficulties. The government denand driven economy resulted in a large transfer of savings from the private to the public sector, crowding-out the private activities, and ultimately weakened the role of the banking system.

\section{c. Use of monetary instruments unt 11 late 1980 s}

Since the early 1980s through 1988, money and credit policles were essentially geared toward the overall strategy of stimulating donestic econonic activity. Accordingly, commerclal banks' reserve requirements, liquidity ratios, credit guidelines, and interest rate ceilings were adjusted frequently to support bank liquidity and encourage domestic lending. Some of the instruments used to this effect included lowering the ceilings on balances held abroad in relation to their current foreign commitments; extending credit against securities; lowering the maximum lending rate charged by the commercial banks and financial companies and the interest rate ceilings on time and savings deposits; and expanding and easing the use of the export credit facility. In 1987, the CBJ introduced further measures to bolster bank liquidity in order to facilitate domestic lending activity. These measures included lowering of the amount that commerciel banks were required to invest in stocks of public shareholding companies from 15 percent to 9 percent of their capital and reserves; reducing the amount of treasury bonds that the commercial banks were required to hold against demand deposits from 9 percent to 5 percent; and. subsequently, eliminating the requirement that commerclal banks hold treasury bills and government bonds against deposits.

\section{Honetary policy under government stab1llzation programs, $1988-94$}

\section{a. Use of monetary instruments}

Monetary policy was tightened significantly beginning in late 1988, in the wake of the energing balance of payents crisis and intensified pressures on the exchange rate and donestic prices. To encourage donestic savings nobilization, the cellings on bank deposit rates were renoved and the naxinue base lending rate charged by banks and financial institutions was increased in September 1988. The cellings on base lending rates were raised further in February 1989, and the commercial banks' Interest rate structure was completely freed in February 1990, following the renoval of ceilings on the base lending rate. Following the rewoval of the cellings, the base lending rate edged upward to about 12 percent in September 1990, and the effective lending rate increased to the 12-13 percent range (including comission).

The CBJ also raised its rediscount rate and the rate on advances to comercial banks from 5.75 percent to 7 percent in September 1988, and the 
rates were further Increased in steps to 8.5 percent by August 1989 restoring positive real interest rates by 1991 (Chart 20). In line with the increase in the interest rate structure, the rate of the export financing facility was raised to 8 percent for exports to Arab countries that had trade agreements with Jordan, and to 6 percent for exports to other countries in August 1989. The rates on government securities were also raised during 1989-90. The rates on treasury bills were increased from 5 percent in 1988 to 6.25 percent in September 1990, and the interest rate on government bonds with maturity of 6 years was increased to 9 percent.

In addition to raising the interest rate structure, beginning in late 1988 the CBJ introduced a number of eessures to tighten domestic credit expansion. The required reserve ratios on time and savings deposits in Jordan dinars were raised from 6 percent to 9 percent, the same ratio which was applied to dinar demand deposits. The required reserve ratio on dinar deposits was increased further to 11 percent effective October 1989 . Moreover, the commercial banks were required to place on deposit with the CBJ 35 percent of their foreign currency deposits (of residents and nonresidents), including advance import deposits denominated in foreign currency by June 1989. I Moreover, to attract foreign currency deposits to the banking system, the 1 imit on such deposits by residents with the commercial banks and financial institutions was increased from JD 30,000 to JD 50,000 in July 1988 and further to JD 150,000 in September 1990. 2/ In October 1990. a reserve ratio of 5 percent was imposed on investment banks, and the minimum ratio of capital and reserves that banks and finance companies were required to hold in public shareholding companies was raised from 15 percent to 20 percent. With a view to tightening credit, commerclal banks were prohlbited from extending credit against foreign currency deposits, and their overdraft facilities were restricted to 20 percent of their credit facilities. Financial institutions were prohibited from extending credit in excess of JD 200,000 to any one client, without prior approval from the CBJ. Cellings were also imposed on credit expansion to banks' board members and employees, as well as to limited private shareholding companies.

Following the tightening of the credit pollcy stance from late 1988 through 1990, the stance reanined broadly unchanged in 1991 in the aftermath of the regional crisis, and was further tightening in 1992-94. Inflation (consumer prices) decelerated sharply during $1989-94$ and returned to its historical low levels, which are comparable with inflation performances in industrialized countries and far lower than many countries in the Middle East region. In view of the credit expansion to the private sector by over 7 percent (of the beginning perlod stock of broad money) in the first quarter of 1992 and persisting excess liquidity in the banking system, the

1 An internationally competitive interest rate is payable on these foreign currency deposits and a penalty of 10 percent per annum (payable in foreign currency) is required on the amount of the shortfall.

2) Jordanians working abroad are exempt from these limits. 
CBJ adopted a series of restrictive measures to reduce excess liquidity in the banking system. The reserve requirements were raised by 2 percentage points to 13 percent on commercial banks and to 7 percent on investment banks in April 1992 and subsequently by an additional 2 percentage points in early 1993, with a view to siphoning off excess liquidity. Furthermore, moral suasion was used with commercial banks to restrain lending.

Additional measures were implemented in May 1992. First, the CBJ opened a new six-month deposit facility for commercial banks with an interest rate of 4 percent; previous facilities were for a duration of up to three months, and carried interest rates of $1-2$ percent. $1 /$ Second, a capital adequacy ratio of capital (including reserves) relative to credit of 1 to 10 for all commercial banks was introduced for the first time. Third, a new maximum loan to deposit ratio of 90 percent was established. All commercial banks were required to observe both the capital adequacy ratio and the loan/deposit ratio. Commercial banks which were in violation of any of these ratios had to consult immediately with the CBJ on a timetable to achieve compliance.

The credit rationing resulting from the use of direct instruments for credit control prevented the development of proper market instruments to allocate efficiently scarce financial resources. In particular, the CBJ avoided intervention through its reserve or base money--as a key instrument to manage the liquidity in the banking system--in order to manage the supply of broad money. Such a monetary management would have required a reasonably good understanding of the money multiplier during the 1980s-.including its various constituents.-in order to estimate the reserve money consistent with a desired level of broad money. Such an analysis (see Appendix III) indicates that, reflecting the trends in its main constituents (public's cash holdings and commercial banks' legal and excess reserves) the money multiplier increased in the early 1980s, reflecting the fall in the public's cash to deposit ratio, and decreased during 1987.90, reflecting in part the regional financial and political turmoil. The money multiplier recovered to its pre-crisis level by 1991 and remained at about this level thereafter.

In 1994, monetary policy was geared toward maintaining the attractiveness of JD-denominated financial assets, in support of the exchange rate policy, and to build up gross official reserves to a more comfortable level. Consistent with this policy, interest differentials in favor of JD-denominated assets were increased to about 2.7-2.9 percentage points vis-à-vis U.S. dollar-denominated assets of similar maturity. Reflecting the effect of this high interest rate policy, broad money expansion was limited to 8 percent, well below the nominal GDP growth of 9.9 percent. The increase in net domestic assets of the banking system was limited to 6.6 percent of the beginning period stock of broad money, partly reflecting the tight credit stance, but mostly net repayments to the banking

1 Reserves held at the $C B J$ under the previous facilities amounted to about 6 percent of the money stock. 
CHART 20

JORDAN

PRICES AND INTEREST RATES. 1970-94

(Percentoge changes)

Nominal and Real Interest Rotes 10
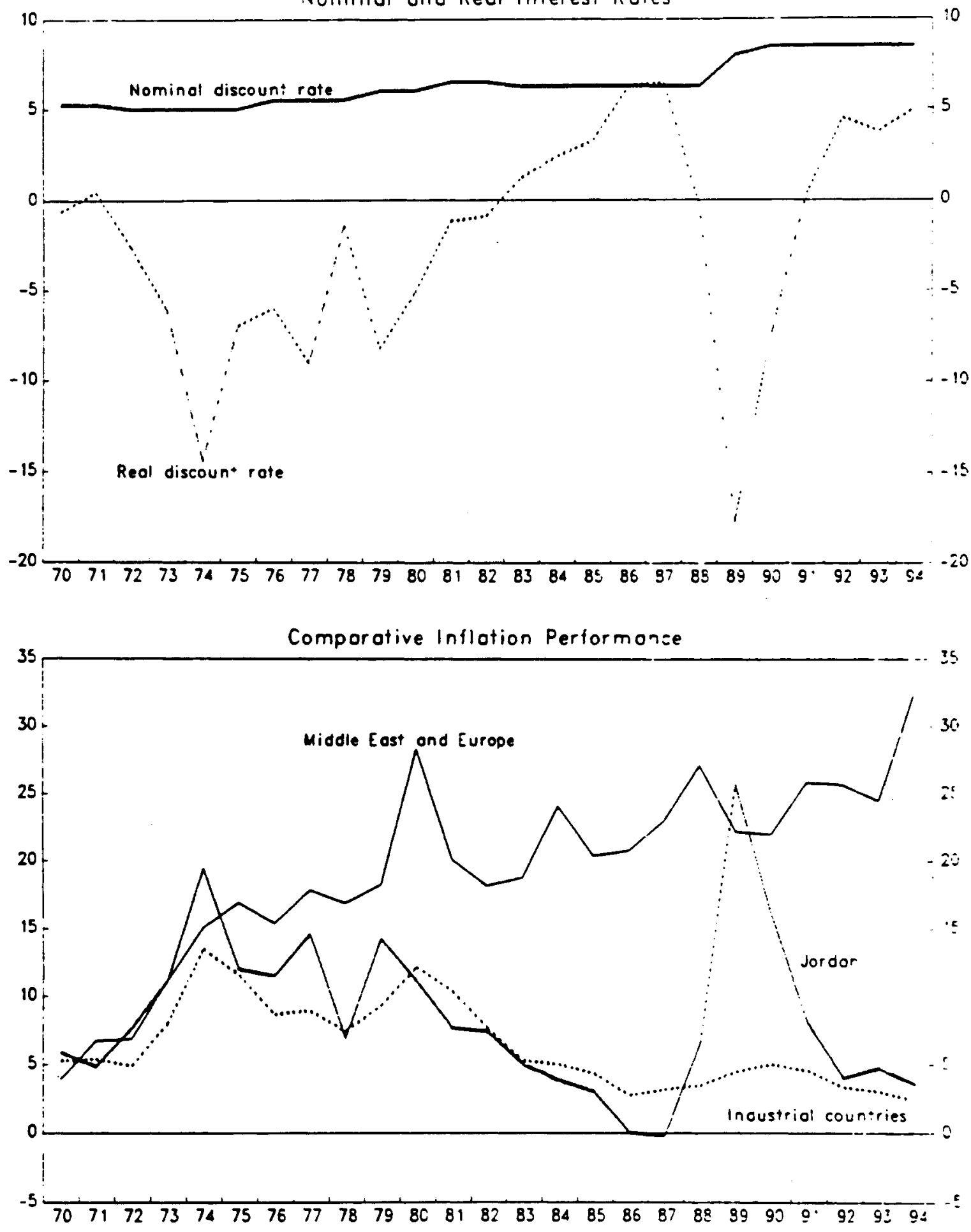

Source: Deportment of Statistics, Covernment of Jordor; Cerl. Bank $c^{\prime}$.smon 
This page intentionally left blank 
system by the central goverment and the contractionary effect of other items (net) resulting from the accumulation of reserves and capital by comercial banks.

\section{b. Banking supervision and resulatory masures}

Bank supervision was strengthened in 1989 in the wake of the financial problens facing two major domestic comercial banks (the Petra Bank and the Jordan Gulf Bank). The Insolvency of the Petra Bank surfaced in August 1989, following the bank's inability to comply with the directive requiring all banks to place 35 percent of their forelgn currency deposits with the CBJ. The authorities acted pronpty to prevent a banking crisis by injecting liquidity into the Petra Bank, to neet the run on its deposits and to settle sone of 1 ts foreign obligations. Financial support was provided through an overdraft facility with the CBJ. Moreover, a special committee was created by the Economic Security Council to oversee the operations of the Petra Bank. The latter was eventually placed under liquidation, and the management of its deposits was entrusted with the Housing Bank in July 1990. The same committee also appointed a new management to conduct the operations of the Jordan Gulf Bank, which was facing difficulties as a result of doubtful loans over the years. Finally, the CBJ issued a number of additional regulatory weasures governing loan loss provisioning, capital adequacy requirements, and portfollo management of the comercial banks (see Append (x IV).

\section{Developnent of Amman Financial Market (AFB)}

The APY is one of the nost active energing capital narket in the world. The ratio of Jordan's aarket capitalization to GDP, which stood at about 74 percent in 1992, exceeds that in most energing warkets, and is similar to that of industrial countries (Table 10). Together with the Istanbul Stock Exchange, the AF is one of the leading capital arkets of the MiddleEastern countries. I It ranked fifth out of 45 emerging markets in terms of total return index in 1992.

Since 1990, the performance of the AFY has been inproving steadily, with the AFY Index registering annual gains averaging 25 percent and the index of total returns inproving arkedly. However, during 1993-94, the Amaan Stock Exchange was somewhat less buoyant than in 1992 due to a tightening of credit since the second half of 1993; the number of trade shares declining by 30 percent to JD 245 million in 1993 and further to JD 134 aillion to 1994. Since 1990, the increase in the index has been broad-based, with the industrlal sector registering the best performance followed by insurance, banking, and other services. Unlike other emerging capital markets, the AFM is dominated by domestic comnercial banks and is

1 For more details, see M. El-Erian, and M. S. Kumar, "Emerging Equity Markets in Middle Eastern Countries," IMF Staff Papers, Vol. 42, No. 2, June 1995. PP. 313-343. 
Table 10: Comparative Perforwance of Emerging Capital Mertets, 1994

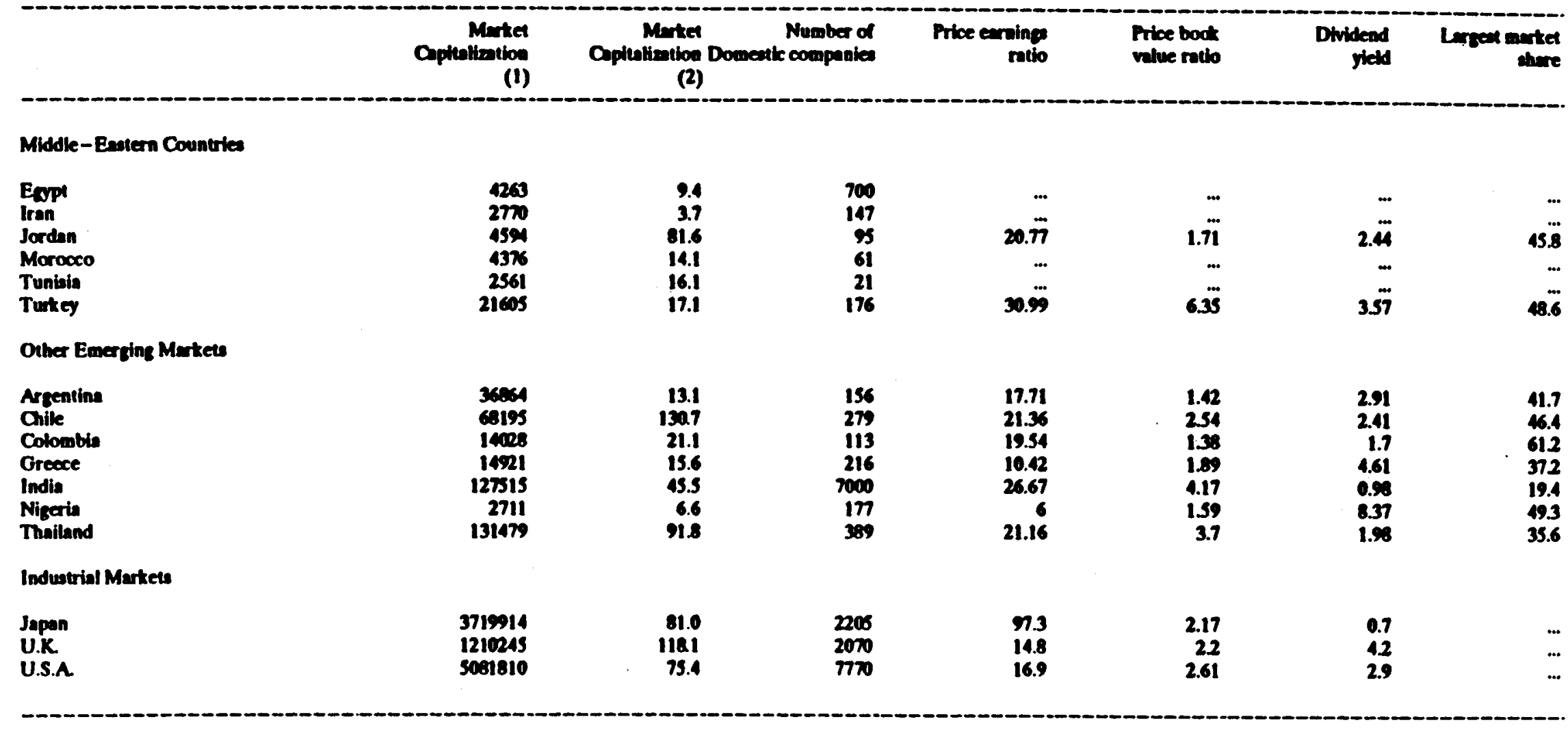

Source: Emergiag Sloct Martets Factboct, 1995. IF.C.
(1) in millions of U.S. dollar
(2) as a percentage of GDP
(3) share of martet held by the 10 largest slocks 
characterized by a low foreign participation. Although influence of foreign investors is increasing, nost of the arket participants are Jordanian ( 85 percent in 1992). Residents of some neighboring Arab countries also participate in the stock arket. Although repatriation of investment income in any convertible currency out of Jordan by Arab and non-Arab investors is free of restrictions, foreign participation of residents from non-Arab countries has so far been linited.

A range of econoaic and institutional factors has contributed to the successful development of the Jordanian equity market since 1990 which enhanced considerably investors' confidance in the Jordanian economic potential. The econonic factors include the recent gains in macroeconomic stabilization, the progress ade in reducing the external debt and debt service burden, normalizing payment relations with external creditors, and liberalizing the exchange system. As regards institutional factors, Jordan has enbarked on a comprehensive financial liberalization aimed at better mobllizing and allocating donestic and foreign resources. In particular, the Jordanian authorities decided to: (1) improve the trading, reporting, and accounting systems; (i1) strengthen legal procedures; and (iii) liberalize regulations governing foreign direct and portfolio investments, including ownership, arket access, and repatriation of capital, dividends and profits.

\section{Ongoing and prospective fthancial reforms}

Fiscal consolidation achleved under the adjustnent program and the further adjustnent envisaged under the Government's medius-term nacroeconoaic framework would provide the basic precondition for sustained progress in financial sector reforms. Despite the reforns, unt 11 1994, the CBJ still lacked proper instrumente for monetary control and continued to depend on direct credit controls; in practice, such direct interventions have frequently been delayed and abrupt in nature. Although comercial banks were free to set lending and deposit rates, which were positive in real terms, Interest rates remained generally inflexible. Moreover, because of the prevalling excess liquidity in the systen and individual bank credit cellings, the spread between the lending and deposit rates tended to widen over the years. I In the absence of open-market operations, there had been lintted scope for controlling overall monetary expansion or for reducing excess ilquidity, particularly when foreign inflows were large.

While a detalled blueprint for further financial refore has not been finally issued, some elenents have already been implenented or have been referred to in official pronouncenents. The authorities' strategy, in general terms, entails: (1) controlling monetary conditions using the new instruments of indirect monetary control (Appendix V); (11) maintaining all

1V The difference between the average loan rate and the average rate on deposits widened from 4.6 percent at end-1990, to 4.8 percent at end-1991, to 5 percent at end-1992, and further to 5.4 percent by May/June 1993. 
Interest rates positive in real terms and achieving much more flexibility in the interest rates than in the past, with a view to achieving efficient market-based mobllization and allocation of loanable funds; (11i) using the central bank JD-denominated certificates of deposits (CDs) in a manner that would enable the authoritles to respond to the shifts in the flow of foreign assets and movements in the exchange rate, and to maintain the IIquidity in the banking system consistent with domestic price stability; (iv) elininating redundant monetary control instruments, particularly following the effective introduction of indirect monetary controls, and improving the efficiency of the remaining necessary monetary instrunents; ( $v$ ) removing impediments to the development of the interbank market; and (vi) improving efficiency through enhanced competition among commercial banks and specialized credit institutions such as the Housing Bank, the Industrial Development Bank, and the Agriculture Credit Corporation. Recent progress in these areas of structural reforms are noted below.

Indirect monetary control operations. The CBJ has been holding weekly auctions of CDs since September 1, 1993 with a view to increasingly use this indirect instrument to exercise control over reserve money. For the indirect system of control to have its desired impact, the CBJ is aiming at maintaining the reserves close to their required minimum level at all times by developing proper monetary programming techniques, including testing and improved reserve forecasting. The auctions of CDs are being coordinated with the auctions of treasury bills with regard to the timing of auction and settlement, eligible holders and bidders, and the range of maturities offered.

Improvine the existine instruments and streamlinine cercain facilities. In Iine with the steady implementetion of Indirect monetary control operations, the CBJ streamlined certain facilities and improved existing facilities by: (1) replacing the deposit facilities by CDs as they mature; (1i) eliminating the credit to deposit ratio once the indirect monetary control program becomes effective: $V$ and (iii) viewing the liquidity ratios as playing useful prudential functions but not as monetary instruments. The CBJ is also in the process of: (1) gradually reducing reliance on obligatory reserve requirements as monetary policy instrument: (11) improving the operations of reserve requirements, inter alia, by eventually unifying and reducing the reserve requirements for all banks; and (111) eliminating/ reducing preferential credit facilities and providing any subsidies explicitly through the budget.

Development of domestic interbank market. The authorities are planning to remove the current impediments to the development of the interbank market. To this end, the practice of double reserve requirements on interbank deposits was eliminated in 1994.

1 On prudential grounds, the authorities have already adopted the Basle standards regarding the risk-based capital to assets ratio. 
Developine finnctil instrumnts and nerkets. To enhance the efficlency of the financial systen by allowing different sectors of the financial system to develop according to their comparative advantage: banks primarily focusing on short-tern financing and capital markets emphasizing intermediation of long-term funds. Attainment of these medium-term objectives would involve: (1) elinination of the privileges of certain financial institutions; (11) strict application of new prudential regulations; (1ii) opening the capital anrket to international transactions; (iv) improving accounting tandards, Including standardized plan of accounts at the comercial banks' level; and (v) developing long-term finance institutions through liberalization of long-term savings institutions, development of securitization instruments.

\section{vI. Externil Debt Strategy}

\section{Backeround: Energence of the external debt crisis}

Jordan's economic expansion accelerated in the 1970s in the wake of the regional economic boom, which opened up opportunities for Jordan's exports and for employment of Jordanians in the area, and led to a markedly higher inflow of external grants from neighboring oll-exporting countries. This process continued through the mid-1980s, even when the regional economies started to experience recessions resulting from the collapse of petroleum prices. Despite the ensuing substantial reductions in renittances and foreign grants, during 1984-88 the authorities attempted to maintain their domestic economic policles unchanged. Instead of adjusting to the lower financing avallable, Jordan stepped up its recourse to forelgn borrowing on commercial terms and, as a result, Jordan's external outstanding public or publicly guaranteed debt built up steadily during this period to US\$8 billion by end-1988 (127 percent of GDP), while the outstanding short-term debt reached US\$400 milition. With the slowdown in economic activity and high real interest rates in the world market, the debt burden reached unsustainable proportions.

Reflecting these developments, Jordan's external scheduled debt service payments rose to nearly US\$1.4 billion in 1989; at the sane tine, recelpts from remittances declined and exports slowed down arkedly, so that the scheduled debt service as a percent of exports of goods and services increased to 46 percent in 1989, about five times the corresponding ratio in $1983 \mathrm{l}$. In addition to the high debt service burden, Jordan's external vulnerabilicy was exacerbated and its creditworthiness impaired by the high debt to GDP ratio and by the high dependence on receipts from services,

1 This compares with 16 percent for the developing countries in general and 27 percent for the heavily indebted countries as observed in 1989. The ratio of external debt to exports of goods and services reached 213 percent in 1989, compared with 290 percent for the heavily indebted countries and 135 percent for the developing countries as a group. 
inherently (more) unstable in nature--about one half of the external current account receipts in Jordan derived from services, mostly remittances and receipts from tourism and travel. Indeed, at a time when the market's perception about the emergence of the balance of payments crisis was accentuated, recelpts from services declined, and the Govermment was unable to make all the scheduled debt service payments. Arrears on external debt service payments began to accumulate beginning in 1989.

\section{Debt management strategy after the debt crisis}

In response to the emergence of the payments difficulties, and as part of an overall strategy to achieve external current account adjustment through demand-management policies, the authorities have been implementing since 1989 an external debt management policy aimed at: obtaining debt relief through rescheduling; lengthening of the maturity structure of debt; and reducing the debt burden in relation to GDP over the medium-term. This strategy had four major elements. First, the authorities concluded a restructuring agreement with Paris Club creditors in July 1989 and regularized relations with other bilateral creditors along terms similar to those obtained from the Paris Club. Second, they initiated negotiations with the commercial banks to obtain a multi-year rescheduling of obligations falling due, with provisions for new money and the option for debt conversion at a discount. Third, all new borrowings were limited to longer term maturities and mostly at concessional interest rates. Along these lines, the authorities also converted all short-term debt to medium-term maturities, and no new short-term or nonconcessional debt in the 1-12 year maturity range was incurred. Finally, Jordan canceled most new commercial borrowings which were in the plpeline; in particular, the cancellation of a military alrcraft purchase agreement reduced the debt burden by US\$I bililon.

\section{a. The 1989 Paris Club areement}

About half of Jordan's public and publicly guaranteed extermal debt was owed to Paris Club creditors either in the form of official development assistance or officially guaranteed suppliers' credits. Another 15 percent of the debt was owed to non-Paris Club official creditors such as Arab countries and the Former Soviet Union. Thus, the primary thrust of Jordan's approach to normalize relations with its creditors depended on obtaining debt relief from the Paris Club. At the request of the Government of Jordan, Parts Club creditors rescheduled Jordan's external debt on July 19 , 1989. with bilateral agreements having to be signed before February 20 , 1990. The 18-month consolidation perlod (July 1. 1989-December 31, 1990) coincided with the period of the stand-by arrangement. 
Under the terms of the Paris Club agreement, all arrears and anortization falling due during the consolidation period on account of precutoff date debt $\mathcal{V}$ and $s i x$ months of intereat payments were subject to rescheduling. Total debt relief froa Paris Club creditors was estimated to be US\$587 miliion over the 18 -month period. 2J Under the terms of the Paris Club agreenent, Jordan was required to offer other bilateral official creditors terms not better than those offered to Paris Club creditors. This provision allowed Jordan to receive additional debt relief worth US\$645 million during the same period.

\section{b. Negotiations with the comercinl bank creditors}

Unlike many other heavily indebted developing countries, Jordan's debt to comercial banks was snall in relative teras, accounting for around 15 percent of the outstanding public and publicly guaranteed external debt. Initially, the authorities aimed at achleving a multi-year rescheduling agreement (MYRA) with the comercial bank creditors, extending the repayment period over a longer term. An informal agreement was reached with the Steering Comnittee in October 1990, whereby Jordan agreed to pay all interest obligations in arrears through end-March 1990 and the banks agreed to reschedule/refinance all remaining interest and all amortization obligations.

In the event, the agreenent could not be conpleted because of differences regarding the inclusion of debt buyback option. Jordan's position was that, since some comercial banks were offering to sell Jordan's debt at a substantial discount, it would be appropriate to incorporate a buyback clause allowing Jordan to undertake such operations formally. The Steering Comittee, however, felt that such a buyback provision could lead to a moral hazard problem since Jordan could use the resources released through the MRA to buy back connercial bank debt at a substantial discount. The outcone of negotiations was also clouded by external factors such as the status of negotiations with other major debtors where the exposure of the banks was wuch higher. In the event, agreement had not been reached by the time the regional crisis energed in August 1990. Moreover, as operations to reduce debt and debt service were soon gaining monentum anong nuber of heavily indebted developing countries, the MrRA approach was abandoned.

\section{Changes in debt strategy in the aftermath of the Gulf Crisis}

The August 1990 Gulf crisis severely aggravated Jordan's external situation due to the loss of export markets for goods and services in

1) The cut-off date for Jordan was January 1, 1989, which was six months prior to the beginning of the consolidation period.

2) The maturity period for the rescheduled amortization obligations was 9.3 years with 4.8 years of grace period, and for rescheduled interest obligations the maturity period was 10.3 years with 5.8 years' grace period. 
neighboring countries and of foreign grants. Moreover, there was a sharp reduction in remittance flows, largely resulting from the massive return of Jordanians working abroad. In the event, Jordan was unable to discharge its external debt service obligations, and made payments only to official creditors, primarily to multilateral organizations. Cumulative overdue obligations by end-1991 anounted to almost US\$800 million, and the amount falling due in 1992 was estimated at that time at US\$1.1 billion.

The authorities were aware that the normalization of payments relations with the creditors through regular debt servicing in cash was beyond Jordan's capability, and that Jordan would require exceptional financing through restructuring of the debt and debt service payments. It also became clear that capitalization of the unpaid debt service obligations would lead to an explosive build-up of external debt, and the growth in debt service would exceed the growth potential for the external current account receipts, making the overall situation unsustainable in the medium to long run.

Moreover, the new medium-term outlook implied that, in addition to limiting new borrowing to only concessional terms and longer term maturities, the revised debt management strategy would require more concessional rescheduling terms from Paris Club creditors and the undertaking of debt and debt service reduction operations vis-a-vis the commercial bank creditors and several smaller official creditors.

\section{a. The 1992 and 1994 Paris Club rescheduling agreements}

Immediately after the approval of a new 18 -monih stand-by arrangement with the IMF, Jordan concluded the second rescheduling agreement with the Paris Club in. February 1992. Under the agreement, Jordan obtained debt relief through rescheduling of all interest and amortization on account of pre-cutoff date debt which would be falling due during an 18-month period beginning on January 1, 1992, and all amortization arrears and 50 percent of incerest arrears accumulated up to end-1991. The terms allowed for longer repayment and grace periods than the 1989 agreement. I Overali, the debt relief from Parls Club creditors was estimated at US\$771 million over the 18 -month period and the amount for 1992 (Including the rescheduling of arrears) was estimated to be US\$603 million. The agreement provided, on a voluntary and bilateral basis, for selling or exchange, in the framework of debt for nature, debt for aid, debt for equity swaps, or other local currency debt swaps. Following the extension of the stand-by arrangement with the Fund unt1l end-February 1994, the consolidation period of the 1992 Paris Club was also extended to coincide with the period of the Fund arrangement, under the same terms.

1 For official development loans, repayments would be mide in twenty equal semi-annual payments, the first payment starting on March 31, 2003 (end of the grace period). For other loans, repayment would be made in 14 equal and successive semi-annual payments with a 9-year grace period. 
After the Fund's Executive Board approved on May 25, 1994, a new threeyear program for Jordan under the Extended Fund Facility (EFF), the Jordanian authorities sought further debt rescheduling from Paris Club creditors for debt payments falling due during the program period. In recognition of Jordan's efforts at macroeconomic stabilization and structural reform, creditors granted Jordan more favorable rescheduling terms than under the 1992 rescheduling agreement. They rescheduled all nonpreviously rescheduled debt-service obligations (interest and principal) on account of pre-cutoff date debt; and current maturities (principal and interest) as a result of the 1989 agreement falling due during July 1, 1994 May 31, 1997 on Houston-blended--graduated repayment--terms (18 years repayment, including 3 years' grace period). I/ In addition, all interest payments under the 1992 Paris Club agreement falling due during July 1 , 1994-June 30, 1995 were also deferred, with repayments over five years, beginning December 31, 1997. Total debt relief obtained as a result was estimated at around US\$1.2 billion (including US\$50 million of deferred interest payments) over the consolidation period. Assuming similar terms by non-Paris Club official bilateral creditors, overall debt relief during the EFF period would amount to about US\$1.4 billion.

\section{b. The revised debt strategy vis-à-vis the commercial banks}

In the aftermath of the regional crisis, it became evident that attainment of medium-term balance of payments viability would require operations aimed at a market-based debt and debt service reduction. There were growing concerns regarding the impact of the external debt overhang on the growth potential of a highly indebted country such as Jordan. 2/ While repeated principal rescheduling and interest refinancing (through concerted new money loans) could provide the necessary short-term cash flow support, medium-term projections indicated that the resulting debt stock and debt service ratios would remain very high, well above the average level of.

1 These terms were being applied for the first time for a lower middleincome country.

2/ Specifically, foreign and domestic assessment of country risk may not improve when the stock of contractual debt surpasses economic agents' perceptions of the debtor country's capacity to service the debt. These uncertainties are perceived to increase the cost of capital in excess of the normal return and vitiate the environment for investment over a prolonged period. Issues related to debt overhang, linkage between domestic and foreign indicators of country risks, and impediments against access to credit have been covered in: Dooley and others, Debt Reduction and Economic Activity, IMF Occasional Paper, No. 68 (Washington: International Monetary Fund, 1990); H. Khor and L. Rojas-Suarez, "Interest Rates in Mexico: The Role of Exchange Rate Expectations and International Creditworthiness," IMF Working Paper, WP/91/12 (Washington: International Monetary Fund, 1991); and J. Stiglitz and A. Weiss (1981), "Credit Rationing in Markets with Imperfect Information," American Economic Review, Vol. 71 (June 1981), pp. 393.410. 
respectively, some 40 percent of GDP and 27 percent of exports of goods and services for developing countries facing debt-servicing problems.

The increasing emphasis on operations to reduce debt and debt service was also accentuated by a number of other considerations. First, given the balance sheet situation of sone commercial banks, the assessment at that time was that it could prove difficult to arrange adequate interest refinancing through concerted new noney loans. I Second, apart from the financing implications, the potential absence of such concerted new financing raised comparabllity problems vis-d-vis other official creditors. Third, there was growing evidence that many commerclal banks were willing to dispose of their claims on Jordan, often at substantial discounts. This shift in the overall debt strategy also gained momentum in Jordan in 1992 when, following the record level of repatriation of returnees' savings after the Gulf crisis, Jordan's official forelgn exchange reserves increased markedly. By end-December 1992, the forelgn assets of commercial banks amounted to US\$1.4 billion, out of which some US\$600 million was deposited with the $\mathrm{CBJ} .2 J$

With a view to improving Jordan's debt servicing capacity and creditworthiness in the longer term, the authorities revised their strategy further, seeking more comprehensive restructuring of the debt stock on the basis of a market-based financing menu. 3 Given the favorable circumstances, In early 1993, the Jordanian authorities stepped up their efforts to buyback debt--by then Jordan has been able to extinguish, through cash buybacks, external debt owed to commerclal banks for a total amount of about US\$600 mililon at a cost of US\$115 million. In addition, Jordan devoted US\$39 mililon during the earlier part of 1993 to buybacks from commercial banks, for debt with a face value of us\$100 million, using for this purpose a part of the CBJ's forelgn exchange reserves, together with

1 As reflected in the case of other major debtor countries such as Mexico, Brazil, and Argentina, because of more stringent regulatory provisioning requirements on developing country exposure and the prospects of seemingly endless episodes of concerted new money packages based on existing bank exposure, the erosion of cohesion within the banking community intensifled, and made it extremely difficult to implement new money packages.

2) The proportion of commercial banks' foreign assets held with the Central Bank of Jordan was higher than the legal requirement ( 35 percent) because the banks found it a preferred option, given the excess liquidity prevalling in the economy at that time.

3/ Such an approach involved a menu of options such as reduced interest par exchange, discount exchange and buyback at a discount, in order to bring in particular the contractual value of commerclal bank claims and other debt more in line with Jordan's debt service capacity. 
the proceeds from the issuance of forelgn currency-denominated certificates of deposits by the CBJ. 1

Negotiations proceeded in parallel and, finally, on June 30, 1993 the Jordanian authorities reached an agreament in principle with London Club creditors on the terns for the restructuring of Jordan's external debt to forelgn comercial banke. Jordan contimued to pay 30 percent of due interest until the closing date, December 23, 1993.

The agreenent covered US\$736 mililon in principal and about US\$121 milion in interest arrears. A recalculation of Interest arrears using then lower interest rates entalled a saving for Jordan of about US\$33 million. Banks opted for 32.8 percent of the debt (US\$243 million) to be exchanged for discount bonds $2 /$ and 67.2 percent (US\$493 million) to be exchanged for par bonds $3 /$; only anall fraction of the debt (US\$0.25 million) was bought back in the context of the debt and debt service reduction package, as the buyback price of 39 cents per dollar was well below the prevailing narket price. On the closing date, Jordan made a cash payment of 10 percent of interest on eligible debt to be exchanged for par bonds, and 50 percent of interest on eligible debt to be exchanged for discount bonds. The balance of interest arrears was exchanged for floatingrate past due interest bonds (PDIs). 4/ The overall cost of the package was about US\$150 million, financed by a drawdown of official reserves and the issuance of foreign currency denominated CDs. 5

1 To date, such certificates of deposits have been issued for a total amount of US\$150 nillion.

2) A collateralized discount bond option, at 65 percent of face value, with a buliet payment after 30 years, and interest at floating rate of 6 months LIBOR plus $13 / 16$ per annum. Principal was fully collateralized, in addition to 6-months' rolling interest guarantee.

3 Collateralized par bonds, with a 30 -year bullet payment. The exchange bonds pay interest at a fixed rate of 4 percent for the first 4 years, 5 percent in year $5,5.5$ percent in year 6 , and 6 percent thereafter. Principal was fully collateralized, as well as 6 months' rolling interest guarantee.

4 Repayable in 19 semi-annual installaents with 3 years' grace period, and carrying interest at 6-months LIBOR plus $13 / 16$ per annum. The PDI bonds were not collateralized.

5/ As follows: US\$21 million in interest collateral (US\$6 million for discount and US\$15 million for par bonds); US\$97 million for principal collateral (US\$24 million for discount and US\$73 for par bonds); US\$29 million as a cash down payment for interest arrears (US\$2l for discount and US\$8 million for par bonds); and about US\$3 million in transaction fees. For the balance of interest arrears (US\$91 million), PDI bonds were issued. The cost of the buyback was estimated at around 61,000 pounds sterling. 


\section{c. Nerotiations wh other official creditors}

In order to ensure comparable treatment among creditors, the Government of Jordan undertook to seek rescheduling or refinancing agreenents from all its non-Paris Club external creditors (including suppliers, and non-Paris Club official bilateral creditors) on terns no more favorable than those accorded to Paris Club creditors. As a result of the rescheduling of overdue obligations by Paris Club creditors, the stock of arrears outstanding was reduced from peak of US\$780 million at end-1991 to about US\$120 allition at end-1992 and US\$11 million at end-1993. The authorities have reported progrese in formalizing rescheduling agreenents with some official bilateral creditors not covered by the Paris Club agreenents. However, little progress has been registered in regularizing arrears vis-a-vis some national development funds despite renewed offers by the Jordanian authorities to negotiate debt rescheduling on terms comparable to those extended to Paris Club official bilateral creditors.

In line with the revised debt strategy, in 1992 Jordan completed an agreement with Russia whereby US\$614 a11110n of debt to the Former Soviet Union was extinguished at a large discount. The first payment for the buyback was made in cash for US\$88 million in 1992; further installments were settled during 1993 and 1994 in exports. Similarly, official debt from Brazil was bought at a large discount.

\section{The medium-term outlook}

As a result of lts sound external debt management, geared to restoring access to world financial ankets. Jordan's creditworthiness has continued to improve. By liniting new borrowing and pursuing debt buybacks at substantial discounts, the Government has reduced lts debt to GDP ratio from 193 percent in 1990 to less than 110 percent at end-1994. Successive Paris Club reschedulings have contributed to lower debt service as a share of exports of goods and services fron 45 percent in 1990 to 25 percent at end1994. Horeover, In the wake of the peace process, US\$800 million of debt forgiveness was granted to Jordan mostly by the United States (US\$702 mililon). Debt-for-equity and debt-for-nature swaps with Switzerland and Germany have already been concluded, and more are ilkely to follow.

Nevertheless, the debt/GDP ratlo would st1ll remain high--99 percent by end 1998--even under the assumption of continuing rapid growth of exports, yearly renlttances of US\$1.1 billion, and substantial foreign direct investnent. Whether these would materialize depends cruclally on private sector perceptions regarding the debt and debt-service prospects: the present large debt overhang, however, could act as a disincentive to private sector investment. In order to reassure the markets. Jordan would not only need to continue its sound debt managenent policles, but also to obtain sufficient new concessional financing and, possibly, further debt rellef. Continued strong adjustment and proper incentives through eliminating distortion would also contribute to the attainment of sustainable exportoriented growth and help improve Jordan's creditworthiness. 
VII. Liberalization of Trade and Exchange Systems: Jordantan Expertence and Prospects

\section{Introduction}

In late 1988, in response to the balance of payments crisis, Jordan embarked on a reform of its extermal trade system. Trade liberalization gained monentum in 1990, when tariff and nontariff trade barriers were unilaterally reduced. I These neasures were complenented by a reform of the Encouragenent of Investment $L$ aw and institutional reforms in support of the industrial sector. The ongoing reforns ain at a better integration of the Jordanian economy with the rest of the world, by improving external competitiveness to gain market share in forelgn markets, and by promoting a more efficient allocation of resources, especially toward tradeable goods, to widen Jordan's narrow export base. On both counts a notable degree of success has been registered so far. Jordan's external competitiveness, measured by the real effective exchange rate, has improved considerably since 1988, as evidenced by the growth of nontraditional exports and the diversification of its trading partners. As for internal competitiveness, the tradeable sector has become nore competitive and there has been a significant shift in domestic production toward the tradeable sector since 1988. 2/ The continuing liberalization of Jordan's trade system is a cornerstone of its outward-oriented growth strategy, to benefit from regional developments and new opportunities arising in the wake of the peace process.

\section{The structure of Jordan's trade}

Jordan's trade is characterized by an unusually large imbalance: the merchandise trade deficit amounted to 31.9 percent of GDP in 1994 (down from 40.9 percent of GDP In 1993). In fact, in 1994, the value of receipts in the services account (factor plus nonfactor) was almost twlce (191 percent) than that of nerchandise exports; In particular, workers' remittances and travel recelpts were equivalent to 77 and 41 percent of exports of goods respectively (Appendix Tables 46 and 49 ).

Export diversification has continued to increase (Appendix Table 47). Based on the SITC classification of comodities, Jordan's exports in 1988-91 were dominated by traditional exports, wanly raw materials such as potash and phosphates. Other important exports are pharmaceuticals, detergents and fertilizers, together with other manufactures, food and live animals. But phosphates and potash, which accounted for 34.1 percent of exports in 1989, only accounted for 19.4 percent of exports in 1994. By contrast, the share of nontraditional exports has continued to increase: manufactures and

1 Jordan's effort to liberalize the trade regime was supported by an Industry and Trade Policy Adjustment loan from the World Bank.

2) The share of tradables in GDP rose by 25 percent during $1986-1992$ and that of nontradables declined by 8 percent. 
chemicals accounted for 29 percent of exports in 1989 and 34 percent in 1994. As for imports, there has been a shift toward capital goods and raw materials: the share of capital goods increased from 21 percent in 1989 to 26 percent in 1994 (Appendix Tables 48 and 52), allowing for sustained growth with lower imports.

Neither exports nor imports are geographically concentrated, although there has been sone geographic diversification of exports over the last five years (Appendix Table 53). The principal destination of exports in 1994 were other Arab countrles ( 42.4 percent)--particularly Saudi Arabia--India (11.1 percent), the European Union (EU) ( 5.1 percent), and Japan (1.6 percent). The relatively low share of the EU and Japan may be partly attributable to the still doninant role of barter and protocol trade, Iimited list of manufacturing products, as well as institutional barriers to access to those markets. Regarding imports, Iraq ramains one of the most important sources, especially for oll, along with the EU ( 33.2 percent of the total) and the United States ( 9.9 percent), while the share of Japan ( 4 percent) is relatively sall. Although more than 40 percent of Jordan's exports are directed toward Arab countries, they only account for 22 percent of imports. Jordan malntains a trade surplus with Saudi Arabia and India, but has very large bilateral trade deficits vis-d-vis Irag, the EU, and the United States.

\section{Trade regime and trade polfcy reforms durine $1988-94$}

\section{a. Trade reaime prior to the 1989 reforms}

Jordan's trade regine in the late 1980 s was characterized by high tariff and nontariff barriers, and institutional inefficiencies that severely hindered its export and industrial sector perforance. Although the average tariff rate on the value of total imports was around 19 percent, because of widespread exemptions, private firms and households were shouldering a high burden of import taxation in Jordan. The maximum tariff rate was 318 percent, while the bulk of Imports was imported duty free. Nearly 30 institutions were exempt from paying import duty, which implied that about 51 percent of imports into Jordan was not subject to customs duty. Nontariff barriers were widespread, with about 40 percent of domestic manufacturing activities being protected through quantitative restrictions in 1988. The high degree of variations in the tariff rates (between zero and 318 percent, with atandard deviation of 26.1 percent). combined with these nontariff barriers, led to a high degree of variation in effective rates of protection.

As a result of the protective system, the overall incentive structure favored production for the domestic market, despite its ilmited size. There were no significant export incentives to even partly offset the anti-export blas resulting from the very high degree of protection. By the late 1980s, the long-term implications of the extensive protection of the domestic economy became apparent. The import substitution policy promoted and protected an industrial sector that was generally inefficient, and the 
growth potential of the nontraditional export base remained unexploited. This trade policy stance, together with an appreclating exchange rate in real effective term, contributed to low and stagnant level of nontraditional exports. According to sone estinates at that time, the protection regine Imposed a heavy burdan on consuners and Industries that used the products of the protected sectors (equivalent to 9.6 percent of GDP). 1

b. Polfcy chnnges in the trade resine during 1988-1994

\section{- Phasing out of ountitative restrictions}

In order to foster a broadly neutral system of incentives, effective protection was lowered by shifting from quantitative restrictions (QRs) to tariffs and, subsequently, by reducing tariff barriers as a whole. In August 1988, 30 categories of products had their import bans removed and replaced with tariff protection. Following this shift, the remaining QRs could be classified into three categories: (1) five products--tomato paste, fresh milk, certain dairy products, mineral water and table salt--had their imports banned (cigarettes were subject to quota); (11) 11 imported luxury, predominantly consumer, items were banned on a timebound basis for balance of payments reasons; and (111) products whose imports were regulated for a variety of reasons, including health and safety; and mass consumption goods imported by the Ministry of Finance for protection of the poor. At the next stage, the Government eliminated a large number of $Q R s$, including those of the second category, thereby reducing the share of domestic manufacturing protected by QRs from 40 percent in early 1988, to less than 7 percent in 1990. In 1995, In the context of the ASAL, the government eliminated the remaining QRs (with the exception of some essential food items).

Pricing policy also plays an important role in restricting imports. The Ministry of Supply sets distribution margins on imports of consumption goods and for nineteen consurption goods produced in Jordan. The Government sets retall prices for fresh food and vegetables. Price interventions cover 11 percent of domestic consumption. The Government also provides consumer subsidies on sugar, rice, powdered milk and wheat, which contribute to reducing the donestic prices of these goods and may discourage production.

\section{- Tariff reform}

In designing the tariff reform, the Government was constrained by the need to protect revenues fron custons duties, since donestic tax potential was impaired by the underdeveloped nature of the tax system and administrative capacity. Therefore, the lowering of high tariffs was synchronized with the raising of low tariffs so that the average tariff was

1 Jordan: Pollcies and Prospects for Snall and Medium-Scale

Manufacturine Industries; World Bank Report No. 6848-J0; January 1988 (The World Bank Report). 
broadly unchanged, whlle at the same time there was a reduction in the discrimination implied by a more differentiated structure, producing a more uniform tariff regine. Two groups of commodities required special treatment. First, tariffs on a short list of goods, primarily mass consumption items amounting to 6.5 percent of dutiable imports, continued to remain zero in the face of the overall tariff reform. The main items on this list included capital goods ( 3.6 percent of dutiable imports), cereals ( 1.8 percent), books and newspapers ( 0.6 percent), and gold fur financial transactions ( 0.5 percent). Capital goods were included as an integral part of the liberalization of Investnent controls (announced in 1989), under which all investment licensing was renoved and a cumbersome discretionary tariff exemption approval process was replaced by setting all tariffs on capital goods to zero. Second, for luxury goods the total tariff was split into a basic tariff and a consumption tax, the tariff being subject to a statutory legal maximum. The consumption taxes on imports was collected at the import stage, while taxes on similar domestically produced items were introduced in connection with the introduction of a GST in 1994.

For the remaining 93 percent of the 1tems subject to tariff, the range between the maximum and minimum tariffs was reduced to 45 percentage points in two further stages over a two-year period. First, the maximum tariff rate was reduced to 60 percent and the minimum tariffs (except for a few selected basic items) were increased to 5 percent in 1990; this narrowing of the range reduced the variation in tariffs measured in terms of standard deviation to 27.5 compared with 26.1 in 1988. Second, in early 1992, the maximum rate was reduced to 50 percent and the standard deviation further declined to 15.9. Because of neasures to increase the minimum tariff rate to 5 percent, the revenue loss resulting from these two rounds of tariff rationalization was relatively small (less than JD 1 million).

In June 1993, as part of the move toward the introduction of the GST, the coverage of the existing consumption tax was expanded whlle certain specific unit taxes were converted into ad valorem and other rates were ralsed to 10-20 percent. In October 1994, the Goverment lowered all tariffs in excess of 50 percent to a aximum of 50 percent or below (except for tobacco, alcohol, and cars), affecting 21 percent of imports. It also announced the reduction in tariff bands to 6 rates $(5,10,20,30,40$, and 50 percent). These measures were motivated mainly by the required synchronization with the newly introduced GST, given that the GST Is levied, contrary to the consumption tax, on a customs duty-inclusive basis.

The trade reforms Initlated in 1988 were undoubtedly successful. resulting in more unlform tariff regime with reduced variance in tariff rates: the import weighted average tariff was reduced from 34.4 percent in 1987 to 25 percent in 1994; and the tariff coefficient of variation was 
reduced from 167 in 1987 to 88.5 percent in 1994. I The increased uniformity was achieved mainly by reducing the combined tariff and surcharges at the upper end of the spectrum.

\section{- Promotion of exports}

Exports are generally not subject to export taxes, and there are no explicit restrictions on exports from Jordan. However, ir order to overcome the hidden anti-export bias, a number of export promotion initiatives have been undertaken since 1989, including the introduction of a drawback system for import duty and taxes paid on inputs used in exports; measures streamlining adninistrative procedures; the easing of requirements for admission of internediate inputs; rationalizing the arrangements for export finance; and rationalizing incentives for investments in general. The Government upgraded the existing export promotion institution--the Jordan Commercial Center Corporation (JCCC)--into the main institution responsible for export and investment pronotion. Moreover, to rationalize and improve export financing, the working of the export rediscount facility administered by the CBJ was improved in 1990 and further in 1992, by extending both the coverage and duration of export credits while reducing the interest rate subsidy avallable to exporters, and allowing the interest rate for export finance to vary in line with commercial rates.

\section{A strategy for further trade liberalization}

The Government's objective for trade liberalization, as outlined in its 5-year development plan (1993-97), is to foster the outward orientation in trade and investment, consistent with 1ts export-led growth strategy. The move toward a more neutral trade regine is geared to stimulate nontraditional exports and open up to new markets, in order to help Jordan adapt to the rapidly changing external environnent.

1 In 1994, out of a total of 6735 tariff 11nes, 330 (4.9 percent) were zero rated, covering 16.7 percent of imports; 1302 ( 19.3 percent) had a tariff of 5 percent and accounted for 24.6 percent of all imports; 672 (10 percent) had tariffs of 10 percent and accounted for 13.2 percent of all imports; 1229 lines ( 18.2 percent) had rates between 15 and 30 percent, accounting for 20.3 percent of all imports; 1926 (28.6 percent) had tariffs between 35 and 45 percent and accounted for 12.8 percent of imports; 999 ( 14.8 percent) had tariffs of 50 percent and accounted for 7.1 of imports: and 277 had tariffs in excess of 50 percent and accounted for 5.3 percent of all imports. Imports tend to be in commodities with lower tariffs and production in sectors with higher tarlffs. Weighted average nominal rates of protection were quite low in agriculture ( 8.9 percent) and mining ( 1.0 percent) relative to manufacturing ( 24.1 percent), but there were wide variations within manufacturing industries. 
A number of problens are being addressed: the domestic market is small, the trade regime is still rather inward-oriented, characterized by relatively high tariffs and nontariff barriers, and burdensome trade procedures, while the regulatory regime tilts the field in favor of large public enterprises. Before the new Investnent Law, the Investment incentives were discretionary. The design of policy reforms should therefore focus on increasing competition in the domestic aarket among domestic producers, and between domestic and foreign producers.

The current efforts are being carried out simultaneously in the context of the current extended arrangenent of the Fund and within the framework of the World Bank's Trade Pollcy Adjustnent Loan (TPAL). Although the details are still being worked out, the main areas of reform are the following:

\section{- Reduction of import tariffs}

The Government intends to consolidate all import licensing fees, surcharges and other applicable fees into one of the six basic tariff rates, and reduce the consolidated effective naximum tariff rate to no more than 50 percent. These actions, together with those under the ASAL, would entail a lowering of the weighted average tariff from 25 percent to 20.7 percent.

At a second stage, during the EFF period, the number of tariff bands are expected to be reduced to five, and the maximum tariff would be reduced further substantially. Subsequently, tariffs on capital goods are to be reduced to no more than 5 percent. As capital goods constitute about 25 percent of total imports, this would entall a significant reduction of the overall level of tariff protection, and would reduce the need for exemptions on capital goods. Following the tariff reduction envisaged under the program, the weighted average tariff rate would decline to 17 percent (or 13.7 percent if capital goods were at 5 percent). Consistent with this longer term tariff reduction strategy, the Goverment is also considering a plan to reduce the welghted average tariff to 10 percent over the next decade.

The Government remains aware of the fiscal implications of tariff reform. Accordingly, it is planning to implement supplementary excise duty applicable at equal rates on both domestic and imported goods in order to protect revenue.

\section{- Reduction of import cariff exemptions}

Widespread exemptions undermine the system: in 1990-92, over half of imports enjoyed some form of duty-free status, regardless of the formal tariff and surcharge structure. This entalls a considerable tax revenue loss and, more important, since most exemptions apply to raw materials and intermediate goods, tariff protection is more blased toward final goods. There are also numerous exemptions for specific institutions. A significant step forward was taken earlier in 1995, with the elimination of exemptions for government organizations and social and parastatal organizations. 


\section{- Reduction of import controls}

In May 1995, under the ASAL, the Government eliminated the remaining QRs, with the exception of a few essential food Items, and converted them to tariffs. Import licensing requirenents would be eliminated (except for protocol trade and product standards). 1 The introduction of an import registration systen, switching from product-based licensing to a list of approved traders who would not require an import ilcense once registered, is under consideration.

\section{- Establishment of sefesuned mechanisms}

In the cases where a donestic industry would need extra time to adjust to the new environment, it is envisaged that a temporary reimposition of higher tariffs would be allowed. These safeguard mechanisms would be established by law, consistent with GATT rules, granted on a limited basis; resort to anti-dumping and countervalling duties would be minimized.

\section{- Protocol trade and national treatment}

Over time, existing bilateral protocol trade agreements giving preferential treatment of goods originating in specific countries should be phased out or turned into full-fledged free trade agreenents that satisfy GATT rules. The Government has already agreed to review the existing ones to reduce trade distortions.

Before end-1995 an amendment to the GST law will equalize domestic taxes applied to foreign and domestically produced goods. The use of excise taxes will allow higher taxation of certain goods, and should retain the nondiscriminatory treatment of donestic and imported goods.

\section{- Eurther measures to pronote exports}

In addition to streamlining of customs administration, measures are to be taken to further improve the tariff and tax treatment of exports. Tariffs on capital equipment or spare parts used for export production could be reduced. In order to promote export-led growth, as long as tariffs remain high, it would be crucial to strengthen the duty-drawback and temporary admission mechanism schenes designed to give domestic producers access to imports at world aarket prices. Even after a tariff reduction, unless tariffs on intermediate inputs becone negligible, there would be a need for such schemes. Both have been adopted but are not effectively applied due to lack of information and of transparency and predictability in implementation. It would be useful to simplify documents that provide

1 As provided in Import and Export Regulation No. 74 of 1993, but not yet fully effective. 
evidence for duty rebates. The tax treatment of exports could also be improved, for instance by eliminating the stamp duties on financial and other transactions by exporters.

5. Opening up the economy: Joining the World Trade organization (WrO) and arreenent with the EU

Jordan has inftiated negotiations on accession to the Wro and for a trade agreement with the EU. Numerous benefits may derive from wTO membership: MFN treatment, the use of established settlement procedures for disputes, active participation in the formulation of multilateral trade rules, and access to various bodies that facilitate international trade. It would also help the authorities to lock-in trade liberalization measures and to resist domestic protectionist pressures, since GATI rules foster the use of non-discriminatory price-based instruments (tariffs); require equal tax treatnent for domestic and imported goods; and constrain the utilization of QRs and resorting to trade measures--such as surcharges--for exclusively balance of payments reasons.

In the context of a new Mediterranean strategy, the EU aims at progressively establishing an Euro-Mediterranean Economic Area, creating a 33 country free-trade zone within 12 years. Agreements have already been signed with Tunisia and Israel. Against this backdrop, Jordan hes also initiated its negotiations on a trade agreement with the EU. In order to facilitate the economic and social adjustment that this process would entall, the EU would be providing financial support.

\section{Regional developments and future challenges}

The peace process creates number of opportunities for Jordan, opening the possibility of an Investment-led boom in the region that could increase the demand for Jordanian exports of goods and services. But peace also poses challenges. First, although the accord with Israel offers Jordan additional trade opportunities, a set of complex bllateral issues prevents Jordan from reaping immediate benefit from the expanding trade and investment opportunities in the region. Second, there is potential for an expansion of trade between Jordan and the WBGS, but it may be some time before it materlalizes. On the other hand, if a free trade area covering only Israel and the WBGS were constituted, it would represent competition for Jordan. A major restructuring of trade patterns in the region is also likely to ensue from the prospective early liberalization of trade between several regional economies and the EU. For Jordan to remain competitive, it would need to proceed with its efforts at swift trade liberalization.

\section{Developments in the exchange system}

In the wake of the balance of payments crisis in 1989, the payments and exchange system became more restrictive initially to cope with the intensifying balance of payments difficulties. With the improvement in the balance of payments position, however, the exchange system was gradually 
liberalized, and by the end of 1992 Jordan had reverted to the liberal exchange system that it had enjoyed in the past. The specific measures adopted to liberalize the exchange system are summarized below.

In February 1991, the advance import deposit requirements were reduced markedly, and in May 1992 all advance import deposit requirements were eliminated. In November 1991 the CBJ doubled the amounts of foreign exchange that Jordanian residents and nonresidents could take abroad, and in November 1992 these linits were once again doubled to relatively high cellings. The Central Bank also increased substantially the Iimits for resident and nonresident holdings of forelgn exchange deposits in Jordan. As a result of these liberalization steps, by mid-1992 the exchange system had became quite liberal, and, for all practical purposes, the remaining restrictions on current invisibles were not binding for bona fide transactions, and did not hinder foreign investments.

Further liberalizing steps were taken during 1993 and early 1994. In 1993, banks were authorized to offer foreign currency accounts to residents. Licensed banks and financial companies were authorized to offer investment portfolio management services to nonresidents in major forelgn currencies. They were also authorized to offer margin trading services for nonresidents through their nonresident foreign currency accounts credited with foreign means of payment coming from abroad, subject to a 30 percent margin. From January 1994, licensed banks and financlal conpanies were authorized to open accounts in foreign currencies for nonresidents without any restriction. Withdrawals and transfers from non-resident accounts were permitted freely. Also from January 1994, the annuel amount that residents were permitted to transfer abroad to meet current payments for invisibles, without prior approval or justifying documents, was raised further from JD 20,000 to JD 35,000. Transfers by residents in excess of that amount were allowed with supporting documentation, and authorizations were granted liberally. As a result of these measures, current account convertibllity had been virtually achieved. The final step came in February 1995, when the Jordanian authorities formally accepted the obligations of Article VIII, Sections 2, 3, and 4 .

VIII. Social Aspects of the Adjustment Program: strengthening of the Socinl Snfety Net in Jordan

\section{Introduction}

In addition to the traditional family-based social arrangement and the formal system of pension through the Social Security Corporation for the private sector (see Appendix VI) and the Government Pension plans, Jordan needed to strengthen the safety net system for the extremely poor segments of the population in the aftermath of the 1989 economic crisis. Like many other developing and socialist economies, prior to the adjustment effort beginning in 1989 Jordan operated a system of administered prices, primarily involving an overvalued exchange rate. The massive devaluation in the 
Jordan dinar in 1988-89, although an important component of Jordan's effort to ensure sustainable long-term growth and eventual improvement in the overall living standards, in the short term hurt the poor as well as workers receiving inadequate wage adjustments.

The economic crisis of the late 1980s sharply lowered the per capita real income and consumption through a slowdown in domestic economic activity, and lower inflow of workers' remittances and official transfers. The poverty profile deteriorated sharply following sustained improvements during the 1970 s and the first half of the 1980s. The corrective actions to reduce donestic imbalances--particularly containment of the public sector wage bill and other current expenditures, exchange rate realignment and price adjustments--also contributed to the lowering of household income in real terms in the short run. This section describes the developments in poverty profile, various poverty alleviating policies adopted and maintained by the Government since the 1988-89 shock, an overview of the current situation, and the direction of the authorities' medium-term strategy in this regard.

\section{Roverty profile: pre-and post-1989 situation}

Associated with the economic boom, poverty in Jordan declined steadily during 1980-86 and the number of people below the poverty line was virtually eliminated at the peak of the economic boom in the mid-1980s. The share of population below the poverty Iine declined from 24 percent in 1980 to less than 3 percent in 1986/87. However, as the economic situation faltered, the poverty situation deteriorated sharply in late 1980 s and worsened further after the 1990 regional crisis (Table 11). Jordan's rapid population growth has further aggravated the situation by straining the avallability and quality of social services. The strong economic turnaround during 1992-93 is belleved to have helped somewhat in reducing the level of unemployment and alleviating the poverty situation.

\section{a. Developments in poverty and income distribution, pre-crisis situation}

Evidence on per capita output growth and inequality (as measured by the Gini coefficient) during the two decades suggests that: (1) during 1973-80, per capita income increased by 7.9 percent per year while income inequality increased, especially in rural areas; and (ii) during 1980-86, per capita income was flat, but income distribution improved, especially in rural areas. Based on the $1986 / 87$ income and expenditure survey, World Bank estimates indicate that 100 percent of Jordanian households were above the 
Table 11. Jordan: Selected Poverty Indicators, 1986/87 and 1992

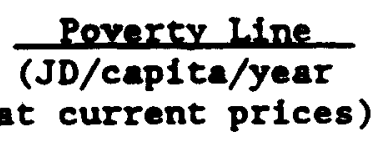

Poyerty hine

at current prices)

Income and expendicures survey.

$1986 / 87$

Al-Saquor's absolute poverty line

World Bank - severe poverty line

- general poverty line

Maximum income - lowest decile

- lowest quintile

$\begin{array}{rrr}148 & 3.0 & 0.3 \\ 59 & -. & -- \\ 79 & -. & -. \\ 197 & 10.0 & 1.9 \\ 246 & 20.0 & 4.8\end{array}$

Income and expenditures survey.

1992

Al-Saquor's absolute poverty line

World Bank - severe poverty line

- general poverty line

Maximum income - lowest decile

- lowest quintile

Employment unemployment. returnees.

and poverty survey 1991

World Bank - severe poverty line

- general poverty line

102

137

261

104

139

223

294

Headcount

Poverty

Index $1 /$ Gap 21

In percent

(20.0.

Source: World Bank, Poverty Assessment, Vol. 1, January 11, 1994.

1 Measures the percentage of population for whom per capita expenditures are below the poverty line.

2) Measures the depths of poverty based on a concept which reflects the percentage of national incone by which poors' expenditure would have to be increased to bring them up to the poverty line. 
severe poverty or general poverty lines. I Even with a much higher level of annual per capita income (JD 148) for the purpose of defining what he called the "absolute poverty line", Al-Saquor (1990) found that 3 percent of the population were below the absolute poverty line. 2/ The depth of poverty--measured in terms of the poverty gap $3 /$ was 1.9 percent for the lowest decile and 4.8 percent for the lowest two deciles. Based on Al-Saquor (1990), the depth of poverty below the absolute poverty line was 0.3 percent.

\section{b. Dimensions and distribution of poverty: post-crisis period (1991-92)}

The poverty situation deteriorated sharply during the perlod of the balance of payments and the regional crisis. Regardless of the measure chosen, comparison of data indicates that poverty was more widespread, deeper and there was greater inequality among the poor. In 1991. 8.7 percent and 19.8 percent of the population were estimated to be below the severe poverty and general poverty lines, respectively, compared with zero percent in 1986. 4/ The poverty gap also deteriorated sharply, widening between $1.9-5.0$ percent.

Based on the 1992 Incone and Expenditure Survey, the poverty situation improved somewhat in 1992. However, the extent of improvement was perhaps somewhat less than what appears from the date analysis because of potential weaknesses in 1991 data. Although the poverty situation appeared to be much better in 1992 than what was envisaged earlier, all indicators point to a marked deterioration compared with the pre-crisis situation. In particular, based on Al-Saquor's absolute poverty line, the proportion of population below the absolute poverty line was almost at 15 percent $1 . e .$, a fivefold increase from the pre-crisis level based on the same measure.

1 The World Bank poverty lines--based on expenditure patterns in lowerincome countries where soclal norms of poverty could be met with lower levels of expenditures--could be too low for Jordun. With a more suitable poverty line, the extent of poverty would be somewhat higher, particularly in the post-crisis period.

2/ Al-Saquor, M. "The Poverty Line in Jordan." In K. A. Jaber, M. Buhbe, and M. Smadi, Income Distribution in Jordan, Boulder: Westview Press, 1990.

3 Measuring the depth of poverty based on a concept which reflects the percentage of national. Income by which Poor's expenditure would have to be increased to bring them up to the poverty line.

4/ The expenditure data for 1991 was somewhat unreliable since the average expenditures reported in the expenditure survey were only 76 percent of those in the national income accounts, compared with 94 percent for the 1992 Income and Expenditure Survey. Accordingly, the 1991 estimates for poverty are likely to be biased upward. 


\section{c. Why poverty deteriorated: economic decline and redistribution}

During the past two decades, Jordan's poverty profile has been directly related to its economic growth performance. As real expenditures per capita declined by 22 percent in real terns (from JD 530 to JD 415 in constant 1986 prices) between 1986 to 1992, real expenditures declined for all groups. For the lowest quintile, the decline in real expenditure was 36 percent, whereas for the top quintile, the decline was linited to 11 percent. During 1986-92, food prices measured in terms of nominal market prices increased by 78 percent due to devaluation of the JD and the reduction/elimination of many food subsidies. 1/ For the bottom quintile, the average food consumption--accounting for about half of their total expenditures--dropped by 36 percent during the corresponding period.

A breakdown in the change in poverty in terms of underlying factors such as growth and redistribution indicates that between 1986 and 1992 the head count index $2 /$ increased by 11.9 percent, about 70 percent of which could be explained by the decline in economic growth (Table 12). However, unlike previous episodes or in other countries under similar circumstances, redistribution of expenditures (an indicator of income)--particularly for the urban areas--partly mitigated the rise in poverty. $3 /$ Rural

population suffered a greater deterioration which was attributable both to a decline in income/expenditure and increasing income inequality near the poverty line. The poverty alleviation pollcles-which are more focused on urban areas because of better accessibility--could have been a factor to this effect.

\section{Poverty alleviation policies}

The Government of Jordan has been historically responsive to the social and human resource dimensions of its development strategy. Accordingly, expenditures on education and health always accounted for a large segment of the total budgetary outlays. This strategy has paid dividends in terms of marked improvements in literacy, health, and other social indicators. Following the economic crisis in late 1980s, in addition to maintaining its commitments to health and education sectors, expenditures on welfare programs were also increased markedly. A large part of this welfare expenditure was in the form of subsidized staple commodities, and programs such as providing direct income support to the extreme poor through the newly established National Aid Fund (NAF) were also introduced at that time.

1 As noted below, a part of the increase was mitigated through the introduction of a food coupon system in 1990.

2) Measuring the percentage of population for whom per capita expenditures are below the poverty line.

3) The negative sign on this component indicates that income distribution around this poverty line became more nearly equal. 
Table 12. Jordan: Factors Contributing to Change in Poverty, Selected Time Periods 1

(In percent)

Change in Headcount Index
$-23.6$

11.9

10.4

17.3

$-14.7$

$-15.8$

6.9

$1986-92$ (Al-Saquor poverty line) $3 /$

All Jordan

Urban sector

Rural sector
Growth

Source of Change Redistri-

bution

Residual

Source: World Bank, Poverty Assessment, Vol. 1, January 11, 1994.

1 The negative sign Indicates that income distribution around the poverty line become more nearly equal.

2) Based on the World Bank poverty line (defined in Table 1), the headcount index in 1980 was 24.5 percent and zero percent in 1986.

3 Based on Al-Saquor poverty line (defined in Table 1), the headcount index was 3.0 percent in 1986 and increased to 14.9 percent in 1992 . 


\section{a. Temporary social safety net instruments}

The Government's expenditure on welfare/safety net programs primarily consisted of generalized food subsidies, food coupons, transfers through the NAF, and health cards. In 1990, total food subsidies amounted to 3.5 percent of GDP, accounting for almost 10 percent of central government current expenditure. Despite the Government's best intentions, the generalized food subsidy was costly and was found to be inefficient from a distributional point of view. Accordingly, the budgetary cost of the welfare program-particularly the generalized food subsidy--has been significantly reduced since its peak in 1990 by enhanced targeting to the poor through the issuance of food coupons. Other than the food subsidy program, the safety net system aims at alleviating poverty through cash or in-kind assistance. The main programs are: cash transfers through NAF; health care subsidies; employment through incone generating projects; and in-kind grants. The Government is the main provider of food, cash and health care subsidies, whereas in the areas of in-kind assistance and income-generating projects, nongovernment organizations (NGOs) and the United Nations Relief Works Agency (UNRWA) are dominant.

\section{(1) Eood subsidy schemes}

In order to cushion the poor from the effect of the large depreciation of the Jordan dinar in 1988-89, domestic prices of a range of food Items sold through the Ministry of Supply were initially left unchanged. This led to growing budgetary outlays for food subsidies to a peak of JD 92.5 million in 1990 (3.5 percent of GDP) (Table 13). Until September 1990, there was no targeting aechanism in place and the income distribution effect of such general subsidies were not satisfactory. 1 Moreover, it represented an open-ended budgetary commitment which was unsustainable given the rapid population growth and the needed fiscal adjustment under the authorities' stabilization program.

In order to contain or reduce the growing budgetary costs of the general food subsidy scheme, a rationing scheme for sugar, rice, and powdered m11k based on food coupons was introduced in September 1990 and has remained in effect since then. The food coupon system aims at ensuring the availability of fixed quantities of these food itens at reasonable prices to all Jordanians. Arrangements were also ande to ensure the availability of additional quantities of these commodities at a price generally higher than the full cost. By introducing the rationing scheme the authorities

1 In principle, only inferior goods justify a general subsidy, since because of demand patterns for such goods, most of the benefits are selftargeted to the poor. Based on the 1987 Income and Expenditure Survey, Ahmad (1991) estimated that, of the subsidized goods, only flour could be considered as an inferior product. Thus, it was likely that the generalized subsidy system up to that point made substantially greater transfers to the rich and middle income classes than to the poor. 
Table 13. Jordan: Food Subsidies, 1988-94

\begin{tabular}{|c|c|c|c|c|c|c|c|}
\hline & 1988 & 1989 & 1990 & 1991 & 1992 & 1993 & 1994 \\
\hline & & \multicolumn{6}{|c|}{ (In millions of Jordan dinars) } \\
\hline Wheat & -6.8 & -36.2 & -40.5 & -34.7 & -43.3 & -43.3 & -39.5 \\
\hline Barley & -3.6 & -7.2 & -6.9 & -7.0 & -8.6 & -9.0 & -3.3 \\
\hline Sugar & 0.7 & -15.6 & -27.4 & -2.4 & 1.9 & 2.7 & -0.5 \\
\hline Rice & -0.2 & -7.3 & -11.9 & -5.2 & -5.8 & -6.7 & -4.8 \\
\hline Milk & $\cdots$ & $\cdots$ & $\cdots$ & -3.9 & .6 .7 & -4.3 & -3.0 \\
\hline Meat $\mathcal{1}$ & 7.3 & -5.6 & -4.8 & $\cdots$ & $\cdots$ & $\cdots$ & $\cdots$ \\
\hline Sorghum 2 & $\cdots$ & $\cdots$ & 2.2 & -2.8 & $\cdots$ & $\cdots$ & $\cdots$ \\
\hline Malze 2 & $\ldots$ & $\ldots$ & -4.3 & -7.3 & $\cdots$ & $\cdots$ & $\cdots$ \\
\hline Other & -4.0 & -1.2 & -9.9 & 2.0 & 8.5 & $7: 0$ & 7.9 \\
\hline $\begin{array}{l}\text { Total surplus (+) } \\
\text { or subsidy }(-)\end{array}$ & -6.6 & -73.1 & -92.5 & $\begin{array}{l}-61.2 \\
\text { In perc }\end{array}$ & $\begin{array}{r}.54 .0 \\
\text { nt of } \mathrm{G}\end{array}$ & -53.6 & -43.2 \\
\hline $\begin{array}{c}\text { Total surplus ( }+ \text { ) or } \\
\text { subsidy (-) } \\
\text { of which: } \\
\text { Generalized } \\
\text { subsidies }\end{array}$ & -0.3 & -3.1 & -3.5 & -2.1 & -1.5 & -1.4 & -0.8 \\
\hline
\end{tabular}

Source: Jordanian authorities.

1 Subsidies for weat were eliminated in 1990.

2) Subsidies for sorghum and maize were eliminated since 1992. 
essentially limited the open-ended budgetary commitment implied by a generalized subsidy. Under the food coupon system and through the implicit cross-subsidization schene, subsidies on account of milk, sugar, rice, and other operations were reduced from JD 43.7 million in 1990 to JD 8.3 million in 1994, notwlthstanding a significant increase in the population, particularly in the aftermath of the 1990 regional crisis. I Other operations of the Ministry of Supply as whole resulted in large budgetary savings, since the price of products were generally anintained well above their import costs. In 1994, means-testing was introduced for food coupons; households with monthly incone higher than JD 500 were excluded from the benefit of the coupon schene.

Although the general subsidy on wheat was costly and there was scope for achieving better results, aintenance of such a program was in part justified on the grounds of its distributional impact. According to the 1987 Household Income and Expenditure Survey, wheat and bread were the main food expenditure items, accounting for about 15 percent of expenditure for the poorest quintile of population in Jordan, compared with only 2 percent for the richest quintile. Thus, even with savings of similar magnitude in nominal terms, the relative gains to the poor households were much higher. Some modest price adjustnents have been ande in 1993 to contain the budgetary costs of the wheat subsidy.

\section{(2) The National Aid Fund}

Since its establishment in 1987, NAF which is an autonomous agency of the Government, steadily increased Its operations to provide direct income support for the extrenely poor fanllies with financial support from the Government. In 1994. NAF provided direct incone support to about 31,000 extremely poor households with 147,000 persons ( 3.5 percent of the population) at or below the poverty level. In that year, the NAF budget amounted to JD 12.7 million which was distributed among three major categories: cash transfers (JD 11.1 million); rehabilitation program (JD 1.0 million); and administration (JD 0.4 million). Notwithstanding the continued fiscal adjustment, the Government increased the budgetary support to NAF from JD 8 mililon to JD 10 million in 1993 and further to JD 12.7 milition in 1994. This increased budgetary support allowed for a significant broadening of NAF operations by providing an additional JD 10 per family per month from 1993 and an increase in the number of families covered under the program by 8,000 to 31,000. 2/ Currently, JD 6.3 per capita per month is on average being transferred to the beneficlaries, that can be compared with the absolute poverty line of JD 11.5 per person per month.

1/ A large part of these budgetary savings, however, reflected declining import prices for sugar and rice, which declined by about 30 percent and 20 percent, respectively, over 1990-92.

2) NAF's monthly assistance to households are JD 25 for the head of household, and JD 5 for the spouse and each additlonal dependent (up to four, as there is a ceiling of JD 50 per family). 


\section{(3) Henlthcare subsidies}

The Ministry of Health gives "health cards" to the poor, granting lower fees to the holder and also waves fees on a case-by-case basis. People with incomes below JD 200 per month are eligible for health cards and disabled person are eligible irrespective of incone. About 50,000 health cards--valid for two years--were issued during 1991-92 and the total number of beneficiaries was estimated to be 322,000 in 1992 . Transfer per capita (subsidies beyond the general subsidy of the Ministry of health) was rather modest at JD 3.5 per person (per year) and the total estimated transfer on this account was also modest (JD 1.1 million).

\section{(4) Other welfare programs}

Other income transfer programs, funded by private contributions and UNRWA, also provide Income support to a large number of households. Under UNRWA's program titled "special hardship cases" more than 30,000 individuals qualified as hardship cases recelve predominantly in-kind assistance equivalent to a monthly transfer of JD 9.2 per capita. The Zakat Fund--funded through private contributions but administered by the Ministry of Aw'qaf--supports 3,000 households on a regular basis with average monthly transfer of JD 7.7 per household in 1991.

\section{Permanent social safety net arrangements}

In addition to setting up the temporary arrangements, the Government's social expenditure programs in the form of education, health, pension and social security system which are avallable to all eligible residents without means tests have also contributed to alleviation of poverty and human resource development in a sustained manner. Traditionally Government's contributions to these programs/arrangements have been high, and priorities for social sectors were maintained even during the adjustment period.

\section{a. Public education system}

Like the experience in most other countries, poverty is inversely related to the rise in the level of peoples' education in Jordan. Illiterates account for 22 percent of the over-21 population, representing about 42 percent of the lowest dec1le. I Since the likelihood of being poor decreases with education, and given that Jordan has achieved remarkable progress in reducing 111 iteracy and establishing good educational standards, the prospect for further poverty reduction through education is good. $2 /$ In spite of the economic crisis during the late 1980s, growth in the number

1 At the other end, people with vocational/secondary educations or higher represent only 11 percent of the lowest decile while comprising 34 percent of the over-21 population.

2) More than 70 percent of the poor and very poor heads of households are older than 40 and grew up before primary education was universal. 
of teachers was more than twice the increase in enrollnent over the last decade; the number of classroons Increased by 50 percent during the $1980 \mathrm{~s}$, and every village with ten or more children of schoolage has a school. Accordingly, the 111 iteracy rate declined from 54 percent in 1965 to less than 20 percent at present, and the absolute number of 11literate adults decreased despite the high rates of population growth. Overall, Jordan maintains a couprehensive public education system which is of high quality and cost effective (Table 14).

Virtual universal prinary school enrollents suggest that public spending on education has reached the poor. Public education costs are 95 percent subsidized and poor students (about 15 percent) are not required to pay school fees. Reflecting these developrents, the bottom quintile spent about 0.8 percent of total expenditure on education compared with 3.5 percent for nonpoor households (1986 Incone and Expenditure Survey).

\section{b. Public health system}

Although Jordan does not have a formal public health insurance system, based on health indicators, the coverage of the current health system is quite comprehensive (Table 15). All allitary and civil servants and their dependents are covered under government health insurance plans, for payment of a small monthly premium. I The Insurance plan covers free treatment at public hospitals and very low fees in prinary healthcare facilities. Only the eligible poor and disabled are allowed to get the benefits free of premiun. All other households also have access to the primary healthcare centers and are charged subsidized fees sonewhat higher than those for public sector employees.

\section{c. Qther safety net norngenents}

The Social Security Corporation (SSC) provides retirement pensions and medical expenses for work-related injuries. The SSC is financed by taxes on private, formal sector enployment, with contributions by enterprises and employees. The schene is mandatory for companies with 5 employees or more and voluntary from others. About 9,000 companies are currently covering for some $27.5,000$ contributors (about one-third of the labor force). Contributors are equivalent to 15 percent of gross wage, 10 percent being paid by the employer and the remainder by the employee. Total number of beneficiaries is currently estimated to be about 23,000 (see Appendix VI).

1 For military personnel and their dependents, the premium is 1.1 percent of the basic salary with a ceiling of JD 1.5 per month; for civil servants, the premium is 2 percent of the basic salary with a celling of JD 8 per month. 
Table 14. Jordan: Selected Countrles: Expenditure on Education and Efficioncy

(In percent, unless otherwise spectlied)

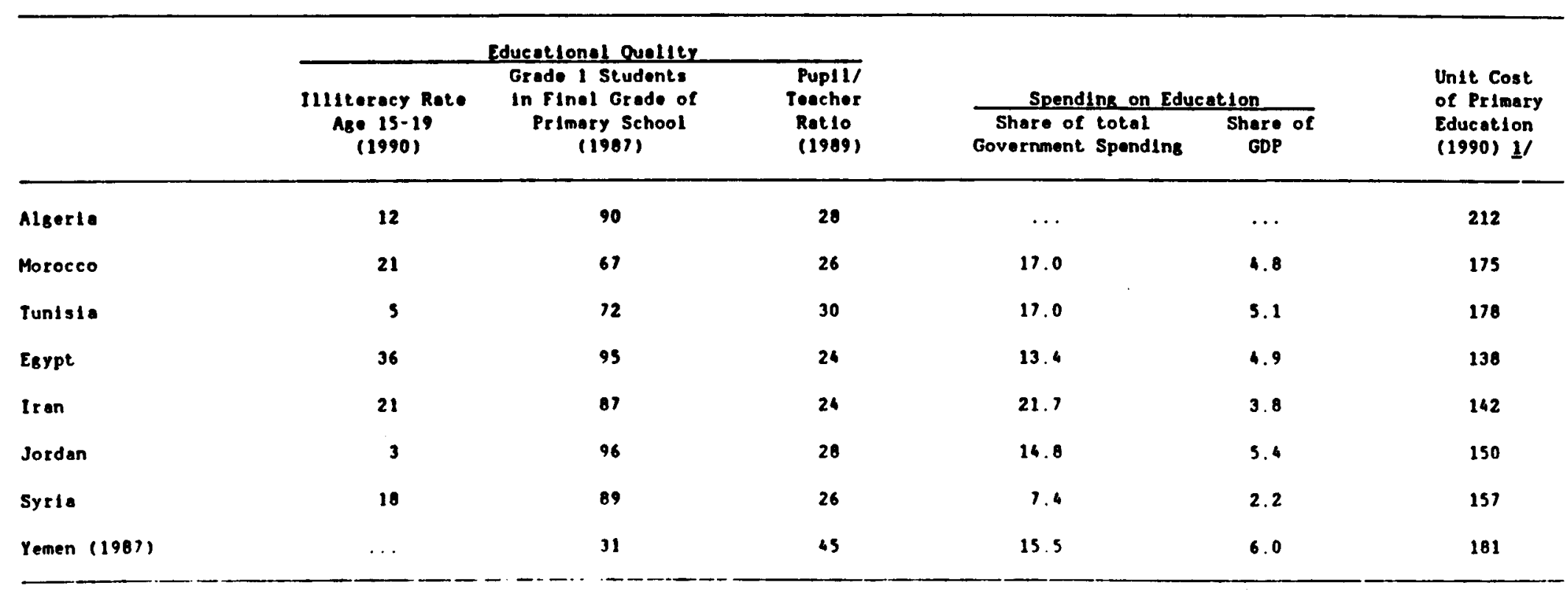

Sources: World Bank (1992): UNESCO (1901): UNICEF (1002); rovernment Finance Statistics, IMF (1992): and World Bank.

1/ In US dollar 
Table 15. Jordan: Health Indicators, 1991

(Per 10.000 population)

\begin{tabular}{lcccc}
\hline & Jordan & $\begin{array}{c}\text { Arab } \\
\text { Nations }\end{array}$ & LDIs & DCs \\
\hline Doctors & 17.1 & 8 & 7 & 27 \\
Nurses, mid-wives & 8.7 & 11 & 11 & 70 \\
Dentists & 3.8 & 3 & 2 & 9 \\
Pharmacists & 5.7 & 4 & 2 & 8 \\
\hline
\end{tabular}

Source: World Bank, Poverty Assessment, Vol. 1, January 11, 1994. 


\section{Qverview of recent developments and medium-term stratery}

While pursuing stabilization and structural reform programs involving large price adjustments, the Government launched new programs and strengthened existing ones to protect the vulnerable segments of the population, the quality and avallability of education and health care services for all Jordanians were also maintained. In the first two years, in the absence of a comprehensive strategy for a social safety net, the program was not well targeted and the costs were not sustainable. However, with the expansion of NAF operations, a coupon system for several food items, upward adjustnents in certain prices, and cross subsidization, the authorities have succeeded in significantly reducing the cost of the safety net program in recent years while improving the targeting of benefits. In particular, the total budgetary cost of the Government's food subsidy program declined from a peak of 3.5 percent of GDP in 1990 to 1.4 percent of GDP in 1993. Following further price adjustments in 1994, the cost declined to about 1 percent of GDP in 1994, most of which was on account of the generalized subsidy on wheat.

In addition to contributing significantly to a sustained reduction in the fiscal deficit, this consolidation of the subsidy program allowed for increasing the budgetary transfers to NAF for direct income support for the poor. NAF expenditure accounted for 23 percent of total targeted safety net transfers in 1992, which has further increased in 1993. Both benefits per person and the coverage have been expanded significantly since 1993; by providing benefits per capita of JD 75 per year, this program succeeded in bringing about 3.5 percent of the population (who were below the absolute poverty line) close to the poverty line. The food coupon system served the bulk of the population, albelt with a relatively low per capita benefits (JD 6.5 per year). It is belleved that for the low/middle-income households.-who do not qualify or intend to avold means-tested transfer programs--food coupons and the generalized subsidies are the only available sources of receiving benefit transfers. The health card system provides fairly comprehensive health care coverage to more than 8 percent of the population, at a reasonable cost (JD 3.5 per person per year).

In addition to maintaining good social infrastructure through expenditure programs on education and health. Jordan has succeeded in establishing a wide network of welfare programs ranging from generalized subsidies to targeted means-tested income support programs. The poverty reduction effect of the generalized subsidy program, however, is believed to be rather limited. On the other hand, targeted programs under NAF and the health card have benefited a sizeable segment of the poorest households. A redistribution of the resources away from generalized subsidies to the targeted programs could further improve the poverty alleviation effect of the Government welfare program.

Sustainability of the cost of the Government safety net program.currently at about 1.6 percent of GDP--needs to be addressed in a mediumterm context. Notwithstanding the remarkable progress achleved in recent 
years, continued efforts would be needed to further consolidate and sustain the recent gains in view of number of factors. As indicated earlier, the recent reduction in the level of wheat and other subsidies was partly attributable to a decline in intermational comodity prices which may reverse over time. High population growth (at a rate of more than 3 percent per year) would also continue to exert pressures on food subsidies and other expenditure programs such as pension, education, and physical

infrastructure. The Government's ongoing bedium-term adjustment and reform program may imply short-term costs to certain econonic/social groups, which would call for new well-targeted short-term aneliorating measures. 


\section{Methodology of Debt Dynamics Accounting Framework}

The successive large fiscal imbalance have led to the accumulation of a large stock of debt. In order to analyze the debt dynamics, the growth of the public debt ratio can be decomposed into five elements:

(i) the structural trend in revenue and expenditure

(ii) cyclical fluctuations

(iii) the discretionary fiscal impulse

(iv) the evolution of interest payments

(v) an exchange rate effect

The purpose of this appendix is to describe the methodology used in assessing: (i) the relative weights of factors behind debt dynamics in Jordan; and (1i) the magnitude of the fiscal consolidation effort required to stabilize the ratio of public indebtedness to output.

Notation will be as follows:

$Y_{t}$ : nominal GDP at current prices in year $t$;

$\mathrm{YP}_{t}$ : potential GDP at current prices in year $t$;

$D_{t}$ : net stock of public debt at the end of year $t$;

$F D_{t}$ : net stock of foreign financed public debt at the end of year $t$;

$B_{t}$ : overall balance of year $t$ (positive value if surplus);

$\mathrm{PB}_{t}$ : primary balance of year $t$ (positive value if surplus);

$T_{t}$ : total revenue in year $c_{\text {; }}$

$\tau_{a}$ : average ratio of revenue to GDP over the period 1975-1988;

$E_{t}$ : total primary expenditure in year $t_{\text {; }}$

$8_{a}$ : average ratio of primary expenditure to GDP over 1975-1988;

$I T_{t}$ : discretionary tax revenue in year $t$;

$I E_{t}$ : discretionary primary expenditure in year $t$;

$I B_{t}$ : discretionary primary balance in year $t$;

$r_{t}$ : nominal implicit interest rate on public debt in year $t$;

Bt $_{t}$ : nominal rate of GDP growth in year $t$;

$E R_{t}$ : average nominal exchange rate (per unit of domestic currency).

Instead of using a "base-year" approach, as is most often the case when estimating trend values, we design a nethodology based on average values. In the absence of reliable proxies, such as utilization rate of fixed investment or unemployment rate, potential output is assumed to grow at a constant rate, equal to the average growth rate observed from 1975 to 1988. Once the growth rate is known, the Initial level of potential output has to be determined. A solution would have been to assume that potentlal output was equivalent to actual output in the base year 1974. However, due to the concave shape of actual output function over time, this would have led to an almost permanent excess of actual output over potential output, disturbing the cyclical component. Therefore, the level of potential output in 1974 has been adjusted in such a way that the undiscounted sum of the difference between actual and potential output became zero. 


\section{a. Decomposition of debt dynamics}

The starting point is that the change in the stock of debt in domestic currency is the opposite of the budget balance, which has a positive value if in surplus. In addition, a correction has to be made for exchange rate variations, which affect the value of the inherited stock of foreign financed debt. Exchange rate variations do affect the budget balance also, through various channels such as foreign interest charges or external grants, but those effects are not singled out in the following analysis. To ignore the exchange rate effect, as is often the case in debt dynamics studies, is a major drawback when significant exchange rate adjustments occurred. The exchange rate pertinent to this analysis is the average one vis-à-vis currencies in which foreign liabilities are denominated, using weights of the outstanding foreign debt.

$$
D_{t}-D_{t-1}-B_{t}+F D_{t-1} \cdot\left(\left(E R_{t-1} / E R_{t}\right)-1\right)
$$

Then the budget balance is decomposed into two parts, the primary balance and interest payments. Interest charges depend upon the outstanding stock of debt and the current average interest rate on that debt. It is assumed that current deficit does not lead to interest payments during the current year.

$$
\text { (A.2) } \quad B_{t}-P B_{t}-r_{t} \cdot D_{t-1}
$$

In turn, the primary balance can be decomposed into its components, i.e., total revenue and total primary expenditure.

$$
\text { (A.3) } \quad P B_{t}-T_{t}-E_{t}
$$

Tax revenue during a given year can be broken down into a structural component, cyclical effect, and a discretionary component. In the absence of discretionary measures, tax revenue are assumed to be a function of the observed output and the average tax pressure ratio. In order to isolate the structural component from the cyclical effect, potential output can be substituted to observed output to capture the structural tax revenue, and the difference is deemed to be the cyclical effect.

$$
T_{t}=t_{a} \cdot Y_{t}+I T_{t}-t_{a} \cdot Y P_{t}+t_{a} \cdot\left(Y_{t}-Y P_{t}\right)+I T_{t}
$$

Primary expenditure can be decomposed in similar way, but assuming that there is no cyclical effect, 1.e. that non-interest expenditure are, in the absence of discretionary measures, a function of potential output and average expenditure-to-GDP ratio.

$$
E_{t}-B_{a} \cdot Y P_{t}+I E_{t}
$$

Substituting (A.4) and (A.5) into (A.3) and replacing the difference between the discretionary tax and expenditure elements by a discretionary fiscal balance element lead to: 


$$
P B_{t}-\left(t_{a}-B_{a}\right) \cdot Y P_{t}+t_{a} \cdot\left(Y_{t}-Y P_{t}\right)+I B_{t}
$$

In turn, substituting (A.6) into (A.2) gives:

$$
B_{t}-\left(t_{a}-B_{a}\right) \cdot Y P_{t}+t_{a} \cdot\left(Y_{t}-Y P_{t}\right)+I B_{t}-I_{t} \cdot D_{t-1}
$$

Finally, substituting (A.7) into (A.1), the result is:

(A.8) $\quad D_{t}-D_{t-1}-\left(t_{a}-g_{a}\right) \cdot Y P_{t}-t_{a} \cdot\left(Y_{t}-Y P_{t}\right)-I B_{t}+I_{t} \cdot D_{t-1}$

$F D_{t-1} \cdot\left(\left(E R_{t-1} / E R_{t}\right)-1\right)$

The five components of the right-hand side of equation (A.8) are the five aforementioned elements, 1.e., respectively, (1) the structural

component, (11) the cyclical effect, (1i1) the discretionary component, (iv) the interest charges, and, ( $v)$ the exchange rate effect.

The debt dynamics can be expressed in ratios to GDP:

$$
\text { (A.9) } D_{t} / Y_{t}-D_{t-1} / Y_{t-1}=\left(t_{a}-g_{a}\right) \cdot Y P_{t} / Y_{t}-t_{a} \cdot\left(Y_{t}-Y P_{t}\right) / Y_{t}
$$

$-I B_{t} / Y_{t}+I_{t} \cdot D_{t-1} / Y_{t-1}+\left(F D_{t-1} / Y_{t-1}\right) \cdot\left(\left(\operatorname{ER}_{t-1} / \operatorname{ER}_{t}\right)-1\right)$

- $\left(B_{t} /\left(1+g_{t}\right)\right) \cdot\left(\left(1+r_{t}\right) \cdot D_{\tau-1} / Y_{t-1}+\left(F_{t} / Y_{t-1}\right) \cdot\left(\left(E R_{\tau-1} / E R_{t}\right)-1\right)\right)$

The last two components of the right-hand side of equation (A.9) are adjustment terms due to the fact that output in denominator relates to different years. The adjustment term vanishes if actual current output is used as a common denominator.

\section{b. Stabilization of indebtedness}

The same budget identities, with the same limited data requirements, can be used to measure the primary balance required to stabilize the indebtedness ratio and to compare it with the observed primary balance.

Substituting equation (A.2) into equation (A.1) gives:

$$
D_{t}-D_{t-1}-P B_{t}+r_{t} \cdot D_{t-1}+F D_{t-1} \cdot\left(\left(E R_{t-1} / E R_{t}\right)-1\right)
$$

Dividing all terms by $Y_{t}$, or equivalently by $Y_{t-1} \cdot\left(1+g_{t}\right)$, and rearranging lead to :

$$
\begin{aligned}
D_{t} / Y_{t}-D_{t-1} / Y_{t-1}-\left(P B_{t} / Y_{t}+\left(\left(r_{t}-g_{t}\right) /\left(1+g_{t}\right)\right) \cdot D_{t-1} / Y_{t-1}\right. \\
+\left(F D_{t-1} / Y_{t-1}\right) \cdot\left(1 /\left(1+g_{t}\right)\right) \cdot\left(\left(E R_{t-1} / E R_{t}\right)-1\right)
\end{aligned}
$$

Therefore, stability of the debt-to-GDP ratio will be achieved if the primary surplus in percentage of GDP is as follows:

$$
\begin{aligned}
\mathrm{PB}_{t} / Y_{t} & =\left(\left(r_{t}-g_{t}\right) /\left(1+g_{t}\right)\right) \cdot D_{t-1} / Y_{t-1} \\
+ & \left(F D_{t-1} / Y_{t-1}\right) \cdot\left(1 /\left(1+g_{t}\right)\right) \cdot\left(\left(E R_{t-1} / E R_{t}\right)-1\right)
\end{aligned}
$$


Assuming no exchange rate effect on the valuation of the outstanding stock of foreign debt, if the differential between the implicit interest rate on public debt and the growth rate, both in nominal term, is positive, stabilization of the debt-to-GDP ratio requires a primary surplus, whose magnitude is proportional to last year's debt-to-GDP ratio and to the size of this differential. On the other hand, if the differential is negative, stabilization can be achleved even with some primary deficit.

The time serles for public debt has been constructed by adding the successive cash deficits. The implicit interest rate on public debt is equal to interest charges paid during a given year divided by the stock of debt at the end of the previous year. 


\section{Koney Demand Function}

Analysis of the broad money demand (money and quasi-money) is usually attempted through the analysis of the income elasticity of the money demand or more directly through the analysis of the income velocity of money.

The transactions demand, the precautionary demand, and the speculative demand for money are usually proxied in the money demand function with key macroeconomic variables, in particular real GDP, consumer prices, and other variables such as interest rates, or real wealth. The estimation of such money demand function in Jordan is rendered difficult because of a number of economic factors (such as the policy of direct monetary control, the recent switch toward indirect control, erratic inflows of labor remittances and transfers of workers' savings), or political factors (such as the August 1990 regional crisis, recent developments and prospects in the West Bank and Gaza Strip). However, a rough estimated relationship for the years 1980-93 would suggest a long-term income elasticity close to unity, and that real demand for money increases with inflationary trends and thus is sensitive to money illusion (Chart 21).

Income money velocity, defined as the ratio of nominal GDP at market prices to the end-of-period outstanding money and quasi-money, had been decreasing steadily during most of the 1980 s, from 1.2 in 1981 to 0.8 in 1989 (Chart 22). This downward trend reflected essentially the monetization of the economy during the 1970 s and 1980s. Since 1989, the ratio has fluctuated within a narrow range, and has been relatively stable.

In the absence of quarterly national accounts, the quarterly path for money demand can be captured with the seasonal information content in available historical data. Chart 23 presents the quarterly demand for money as a percentage of the annual change in money demand. It appears that the largest expansion in money demand occurs generally during the first two quarters of the year, in line with the seasonal pattern for credit and investment. On average. 75 percent of the year's money demand is reached by mid year and the last two quarters account only for 25 percent. I Except for the years 1988-92, when special factors affected the financial system. this seasonal pattern appears rather robust.

1 On average, the annual distribution for money demand is 30 percent for the first quarter, and 45 percent, 15 percent, and 10 percent, respectively, for each subsequent quarter. 


\section{CHART 21}

JORDAN

BROAD MONEY DEMAND, 1980-93

(In millions of Jordon dinars)

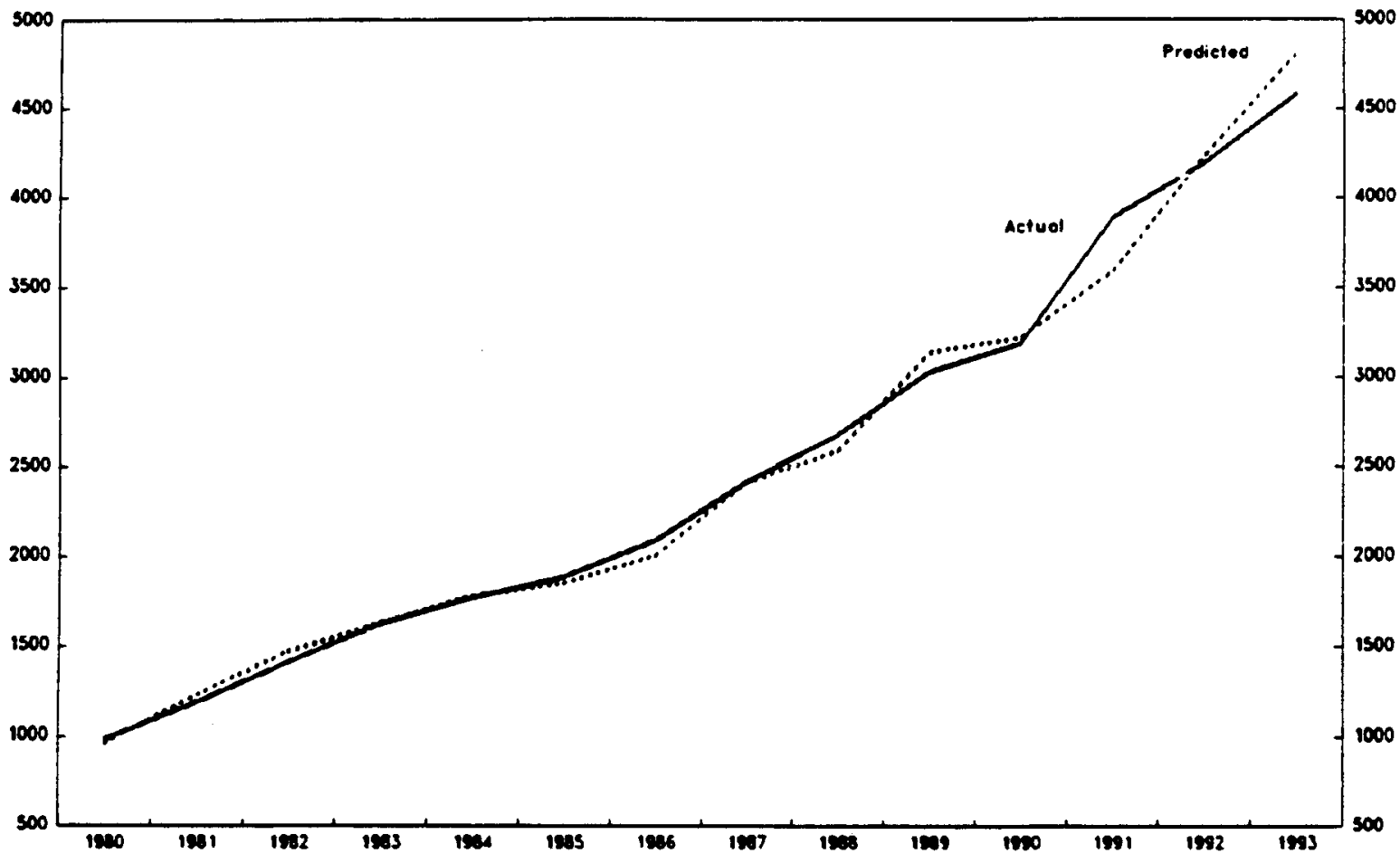

Regression output:

Constant

Std. error of $Y$ est.

$R$ squared

No. ob observations

Degrees of freedom

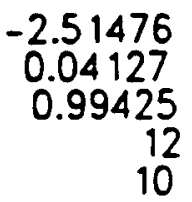

GDP

CPI

DD

$Y$ coefficients Std error of coefficients t-statistics

0.642500

0.123982

5.182207

0.116819

7.989295

0.171518

0.029012

5.911975

Sources: Central Bonk of Jordon; ond stoff estimates. 
CHART 22

JORDAN

INCOME VELOCITY OF MONEY, 1970-94

(In percent)

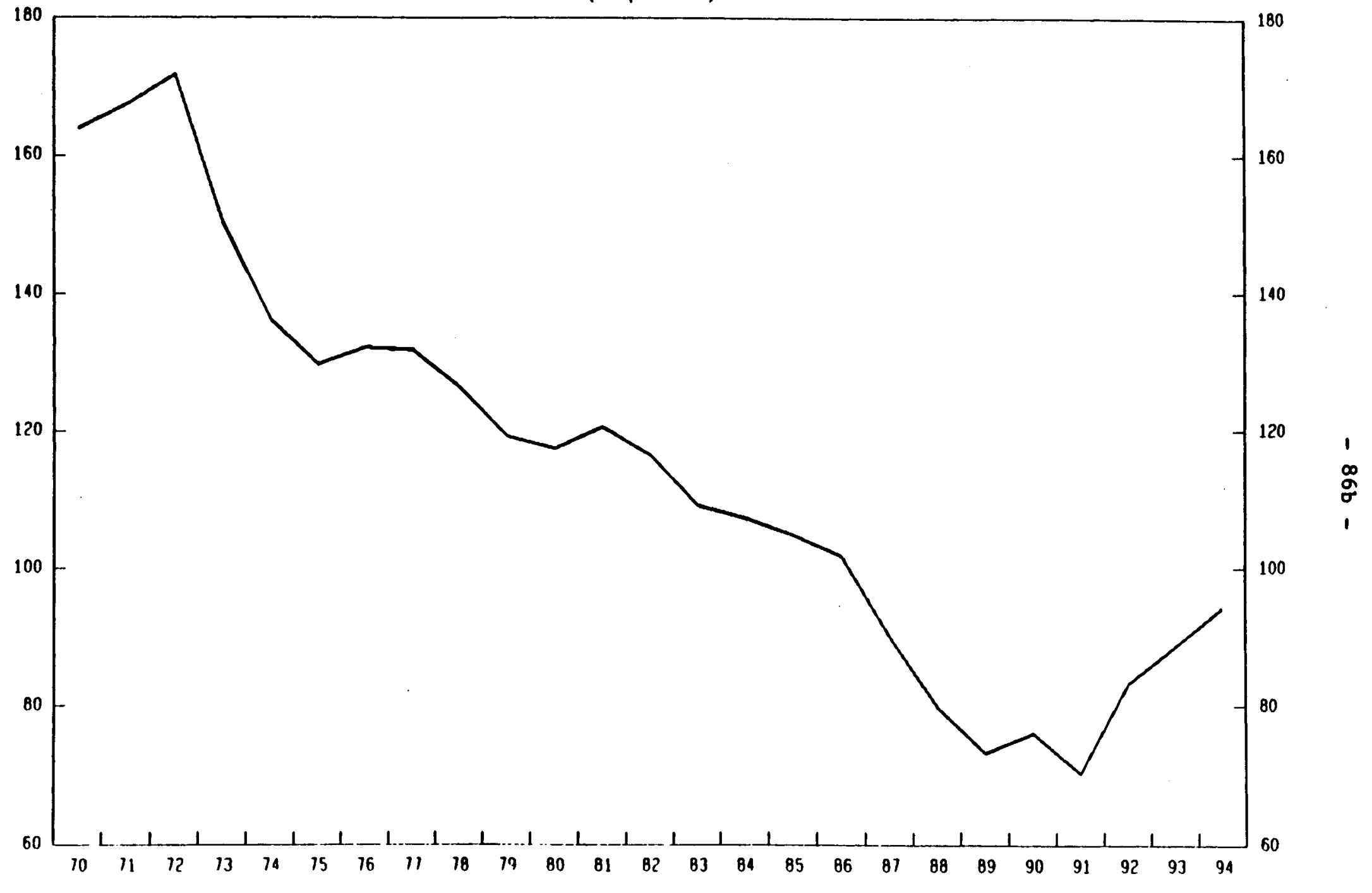

Source: Infernotionol Monetary fund, International finoncial Statistics. 

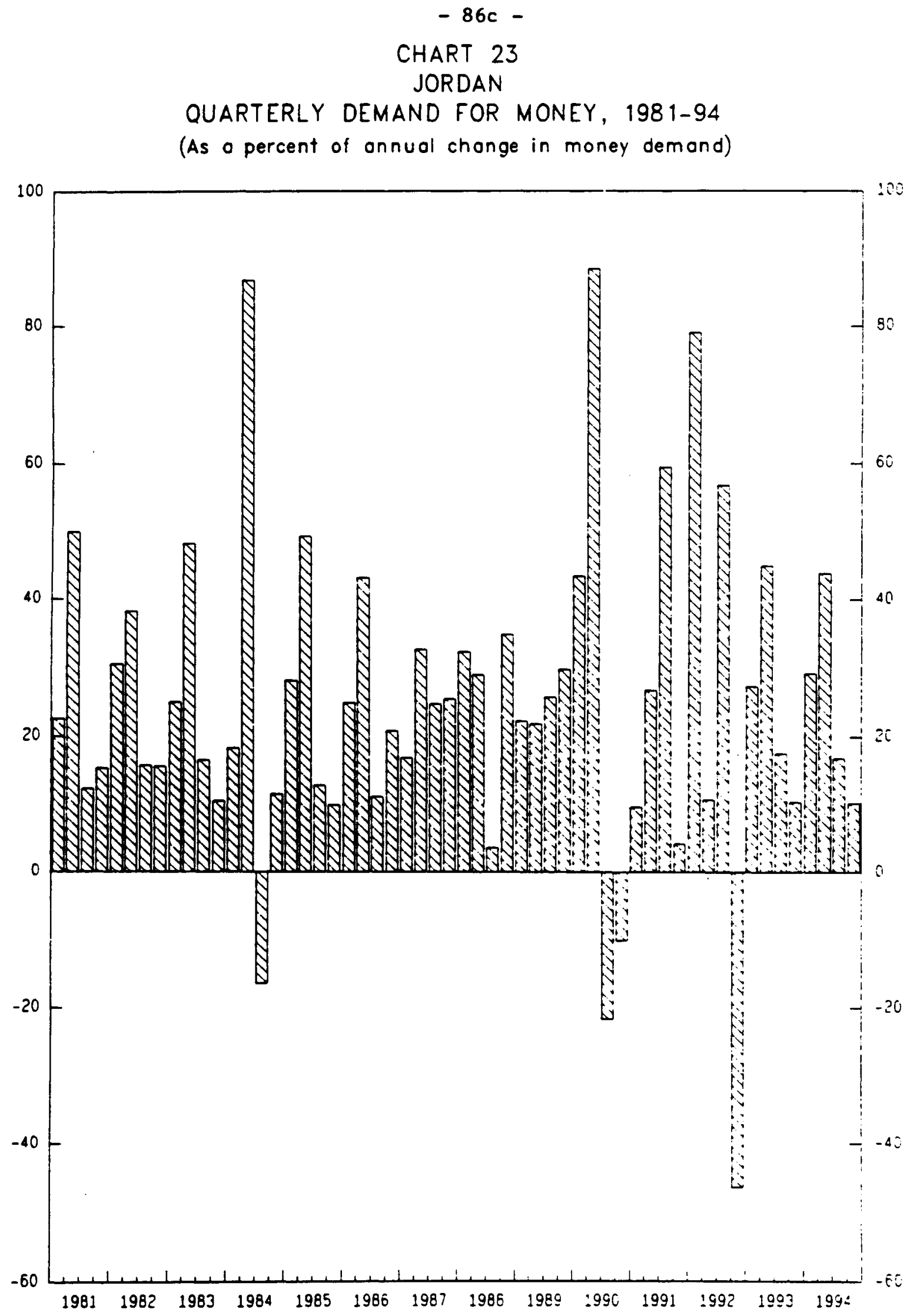

Sources: Central Bank of Jordon: and staff estimates. 
This page intentionally left blank 


\section{Koney Multiplier and Reserve Koney, $1980-94$}

The money multiplier, $\mathcal{V}$ i.e., the relationship between reserve money and broad money has been affected by four factors during 1980-94. First, the public's cash holding over tine; second, the licensed banks' cash in vaults; third, the legal rate for reserve requirements (which is the weighted average of legal rates applicable to licensed banks $2 /$ on various deposits); and fourth, the licensed banks behavior toward constituting excess reserve (excluding cash in vaults). Accordingly, the following key constituents are analyzed during 1980-94.

\section{Cash to deposit ratio}

Cash holdings behavior is reflected in the change in the ratio of currency outside banks to total deposits in the banking system. This ratio has steadily decreased since 1980, except during 1988-90 when special factors (including the collapse of Petra Bank, the bankruptcy of several financial institutions, and the August 1990 reglonal crisis) temporarily undermined confidence in the banking systen. This downward trend is the result of: (1) various institutional and financial innovations, including in particular the multiplication of means of paynents alternative to cash (such as credit cards or banking transfers): and (11) increasing confidence in the banking system. The cash to deposit ratio, which exceeded 55 percent in 1980, declined to less than 30 percent in the early 1990s. The estimated

1 Ex-post, the money aultiplier (k) is simply the ratio of the money and quasi-money stock (MQM) to the reserve money (RM): $k$ - MQM / RM.

Ex-ante, the money multiplier is derived consistent with the cash to deposit ratio $(C / D)$, bank's cash in vaults to deposit ratio (VC/D). required reserves to deposit ratio $(R R / D)$, and excess reserve (excluding cash in vaults) to deposit ratio $(E R / D): k-[C / D+1] /[C / D+V C / D+R R / D+$ $E R / D$ ]. This expression is derived from the following three identities:

(1) $\mathrm{MQM}-\mathrm{C}+\mathrm{D}$

(2) $R M-C+V C+R R+E R$

(3) $M Q M-k * R M$

Identity (1) means that the money supply equals the sum of cash outside banks (C) and deposits of the public in the banking system (D). Identity (2) means that the reserve noney equals the sum of cash holdings outside of the banking system and total bank reserves (Including banks' cash in vaults). A simple manipulation substituting (1) and (2) into (3) yields to the ex-ante definition of the money multiplier.

2) Twenty-two licensed banks (including the Housing Bank) have liabilities in the form of sight and time deposits payable on demand, transferable by check or otherwise usable for making payments. 
equation indicates that the cash to deposit ratio declined at an annual average rate of 1.7 percent during the $1980 \mathrm{~s}$, and was sensitive to developments in inflation (Chart 24). 1/

Furthermore, the analysis of the quarterly cash to deposit ratio reveals a strong seasonal pattern associated with the seasonal consumption/demand of the private sector. On average, the ratio declines during the first quarter, rebounds during the second and the tlird quarters, and decreases sharply in the fourth quarter. However, the stability of this seasonality during 1980-88 was distupted in the late 1980s and in 1990 as a result of the special factors mentioned above. Since 1991, however, this seasonal pattern appears to be visible again, albeit in a less pronounced manner.

\section{Cash in vaults to deposit ratio}

Reflecting improvements in banking management, as well as a deepening of the financial system, the ratio of cash in vaults of licensed banks to deposits tended to decrease during the 1980s, from 1.3 percent in 1980 to 0.8-0.9 percent of deposits since the early 1990s (Chart 25). Although banks' cash in vaults like other deposits at the CBJ are immediate and final means of payment, they cannot currently count toward satisfying the reserve requirements. Until the treatment of cash holdings is changed so that they count as reserve assets, cash in vaults is independent of other reserve assets in Jordan's monetary program.

\section{Lesal and excess reserves ratios}

The woney multiplier is highly sensitive to the ratio of bank's required and excess reserves at the CBJ to deposits. Although legal reserves are supposed to be easily predictable since they are institutional instzuments known with certainty, the existence of different reserve requirements complicates the predictability of this component. Legal reserve requirements are currently higher for commercial banks ( 14 percent) than for investment banks ( 9 percent) because of the Jordanian authorities' belief that investment banks are better able to forecast their l1quidity needs. 2J In addition, with a legal reserve requirement of 5 percent, the Housing Bank was granted an exemption because of its involvement in long-

1 This is apparent from the following regression for the cash to deposit ratio over the period 1980-1993: C/D $-0.017 \star$ Time + 0.05*Inflation + Dummies1988-90+34.6 $(-17.8)$ (5.1) SER-1.3\% R2-.98.

2) Until 1988, legal reserves requirements used to differ according to the nature and maturity of deposits (JD demand, time or savings deposits). 
CHART 24

JORDAN

CURRENCY OUTSIDE BANKS, 1980-94

(As percent of deposits)
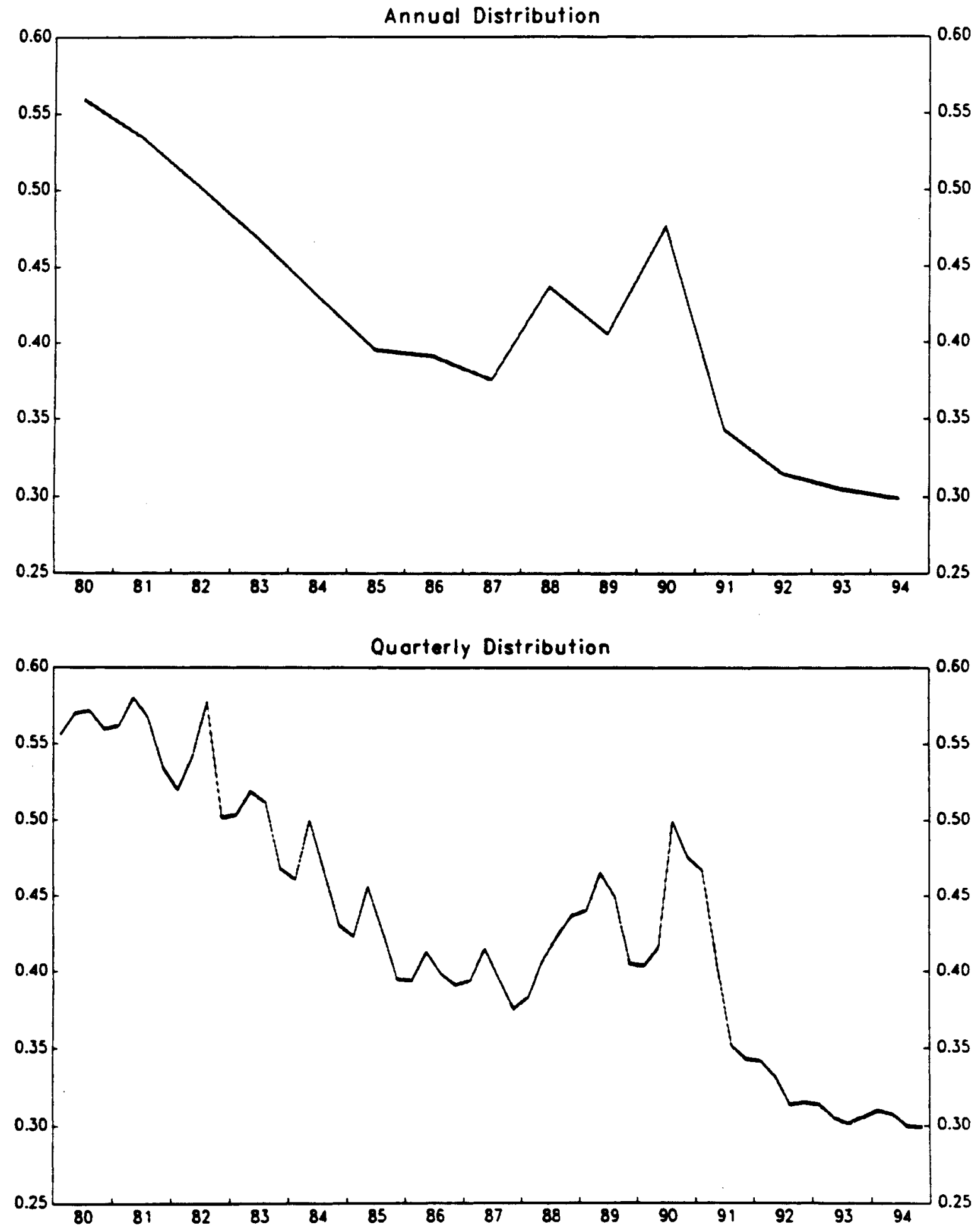

Sources: Central Bonk of Jordan: ond stoff estimotes. 
CHART 25

JORDAN

BANKS' CASH IN VAULTS AND RESERVE REQUIREMENTS, 1980-94

(As o percent of deposits)

Bonks' Cosh in Voults

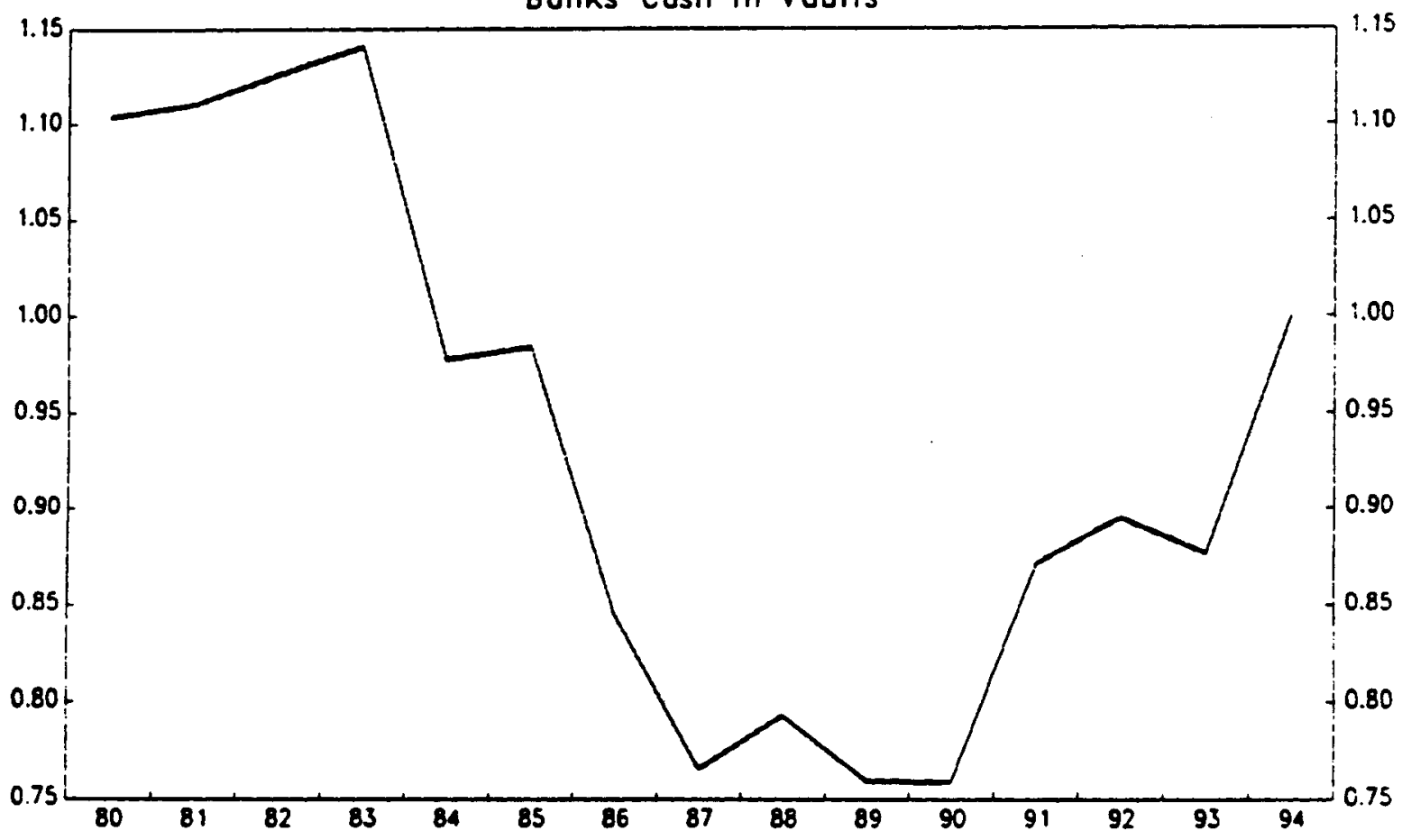

Legal and Actual Reserve Requirements

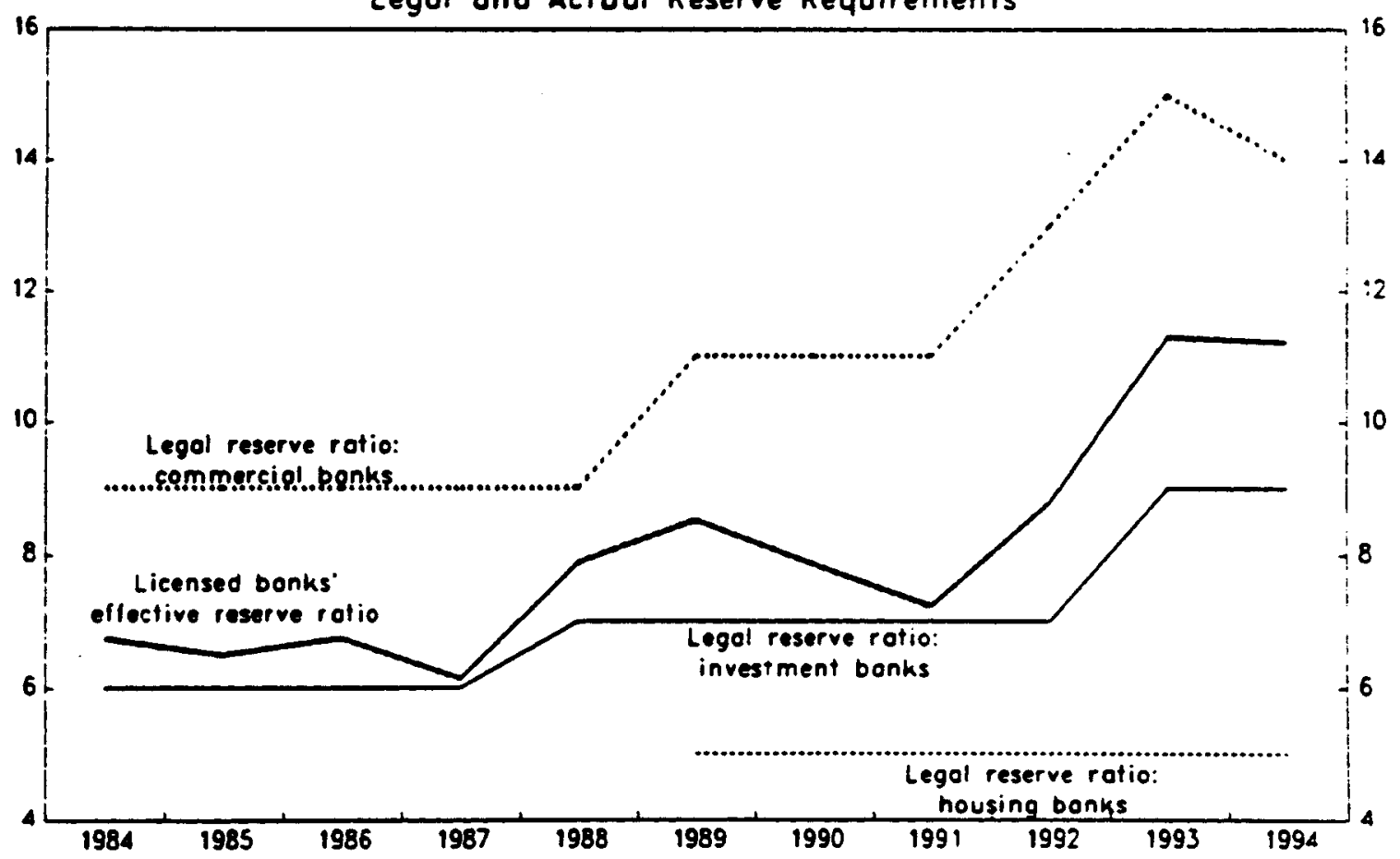

Sources: Centrol Bonk of Jordon; and stoff estimates. 
term financing. 1/ As a result, the ratio of effective reserves to deposits is a weighted average of the legal rates for commercial and those for investment banks, and the fluctuations within the range reflect substitutions in the public deposit behavior between these banks (Chart 25). 2/ In addition, the projection of the actual rate for the legal reserve requirement is rendered nore complex because of: (i) the requirement that reserves be held againet interbank deposits; and (ii) the exemption of advances for export promotion toward reserve requirements.

Bank's excess reserves at the CBJ (excluding remunerated deposits at the $C B J$ ) are less predictable than legal reserves since they are related to: (i) the microeconomic situation of each individual bank; (i1) the interest rate and credit control (credit ceiling) policies; and (iii) individual constraints on commercial banks' balance sheets. Three different phases can be identified in the evolution of the ratio of Iicensed banks' excess reserves to deposits during the 1980s (Chart 26). From 1980 to 1987, the ratio declined from 5 percent to 1 percent, notwithstanding sharp fluctuations around this trend. In 1988, the ratio collapsed and turned negative, reflecting the emergence of the banking system crisis. By the early 1990s, the ratio recovered to 1 ts pre-crisis level, and in the aftermath of the August 1990 regional crisis, the excess reserves accounted for 2.5 percent of total deposits: this latter level seemed to have been the historical average level targeted by the licensed banks to preserve themselves against an unexpected shortfall in liquidity. However, It should be noted that the effective level of excess liquidity should also include the banks' remunerated deposits at the CBJ, which represented half the total banks' deposits at the CBJ in 1992. 3 In 1993, this component of excess liquidity appears to have been largely absorbed--mainly through the newly introduced JD-denominated CDs--and disappeared completely in 1994 as the remunerated deposits of three and six months matured.

1 Since 1994, the Housing Bank is subject to: (1) a 15 percent legal reserve requirement on its commercial activities (which represent less than 1 percent of its total activities); and (1i) a 5 percent legal reserve requirement (which should gradually increase to 9 percent in 1994) with respect to its traditional activities.

2 In 1993, deposits in commercial banks (excluding those of the Housing Bank) represented 71.4 percent of total deposits in the banking system. The total deposits of the Housing Bank and other investment banks represented 18.3 and 10.3 percent, respectively, of total deposits in the banking system.

3 In 1991, the CBJ promoted its three- and six-month remunerated accounts in order to sterilize the large inflows of foreign assets generated by labor remittances and the transfer of workers' or returnees' Iifetime savings from neighboring countries to Jordan. These deposits accumulated to more than JD 350 million out of total deposits of JD 700 million at the CBJ in 1992 . 


\section{Money multiplier}

The money multiplier is defined as the ratio of money and quasi-money (M2 in the case of Jordan) to the narrow concept of reserve money. 1 Reflecting the trends in the above constituents, the money multiplier increased in the early 1980s, up to 3 by 1987 (echoing the fall in the cash to deposit ratio), and decreased thereafter to 2.6 by 1990 , reflecting in part the regional financial and political turmoll. The money multiplier recovered to its pre-crisis level by 1991 and remained at about this level thereafter, reflecting declines in both the cash to deposit ratio and the licensed banks' excess reserves.

1 Money and quasi-money includes currency in circulation and the demand, saving, and time deposits of residents, denominated in JDs and foreign currencies, with both the $C B J$ and the licensed banks (including the Housing Bank). The reserve money is defined as the sum of: (1) currency in circulation (currency outside banks and banks' cash in vaults); and (ii) demand deposits of licensed banks at the CBJ (excluding remunerated deposits and JD-denominated CDs). In line with the recommendations of the Fund's Statistics Department, a broader concept of reserve money would include all demand deposits at the $C B J$, particularly those of the financial institutions, public non-financial institutions and private sector. 
CHART 26

JORDAN

Licensed Bonks' Excess Liquidity, 1980-94

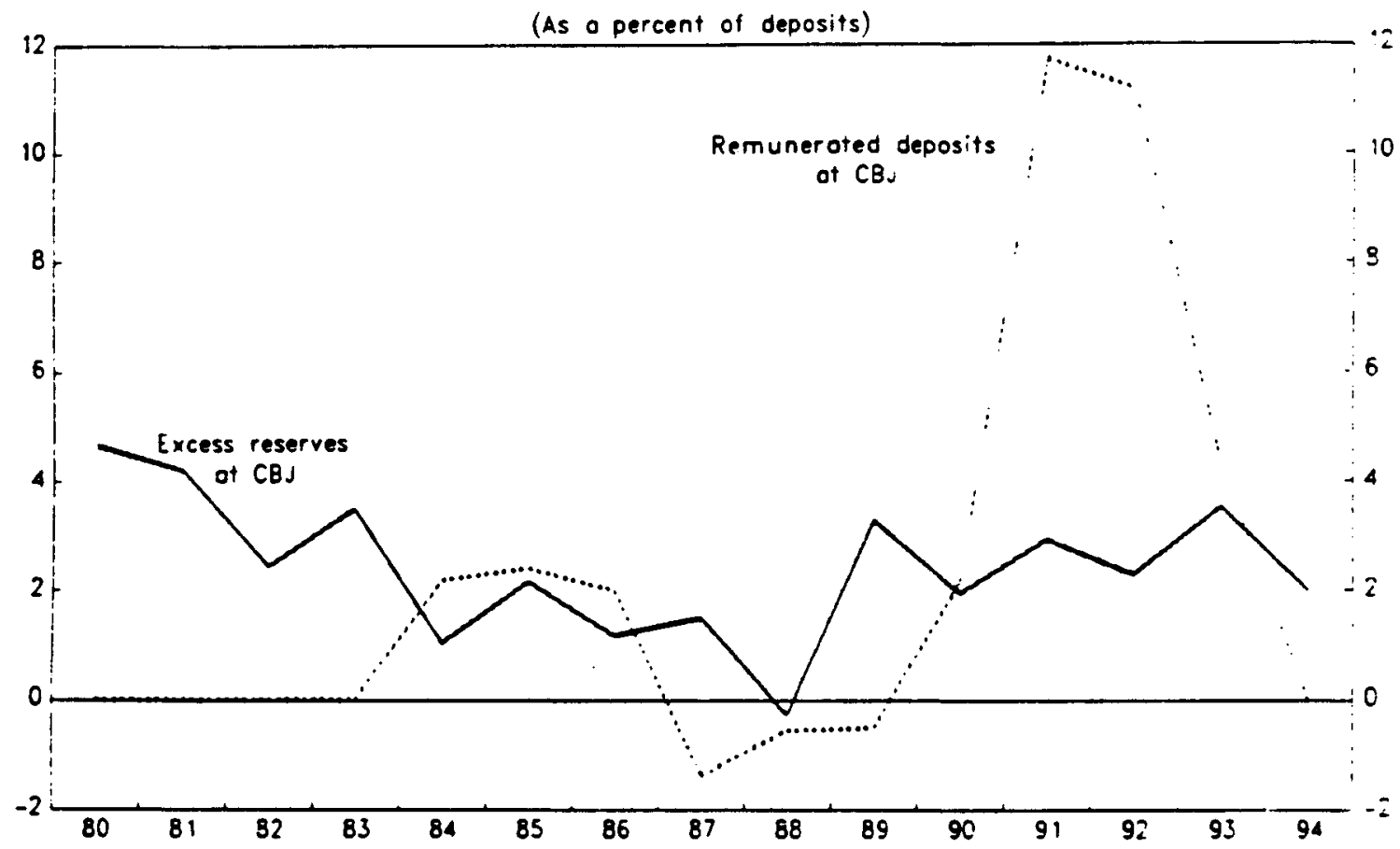

Money Multiplier

(In percent)

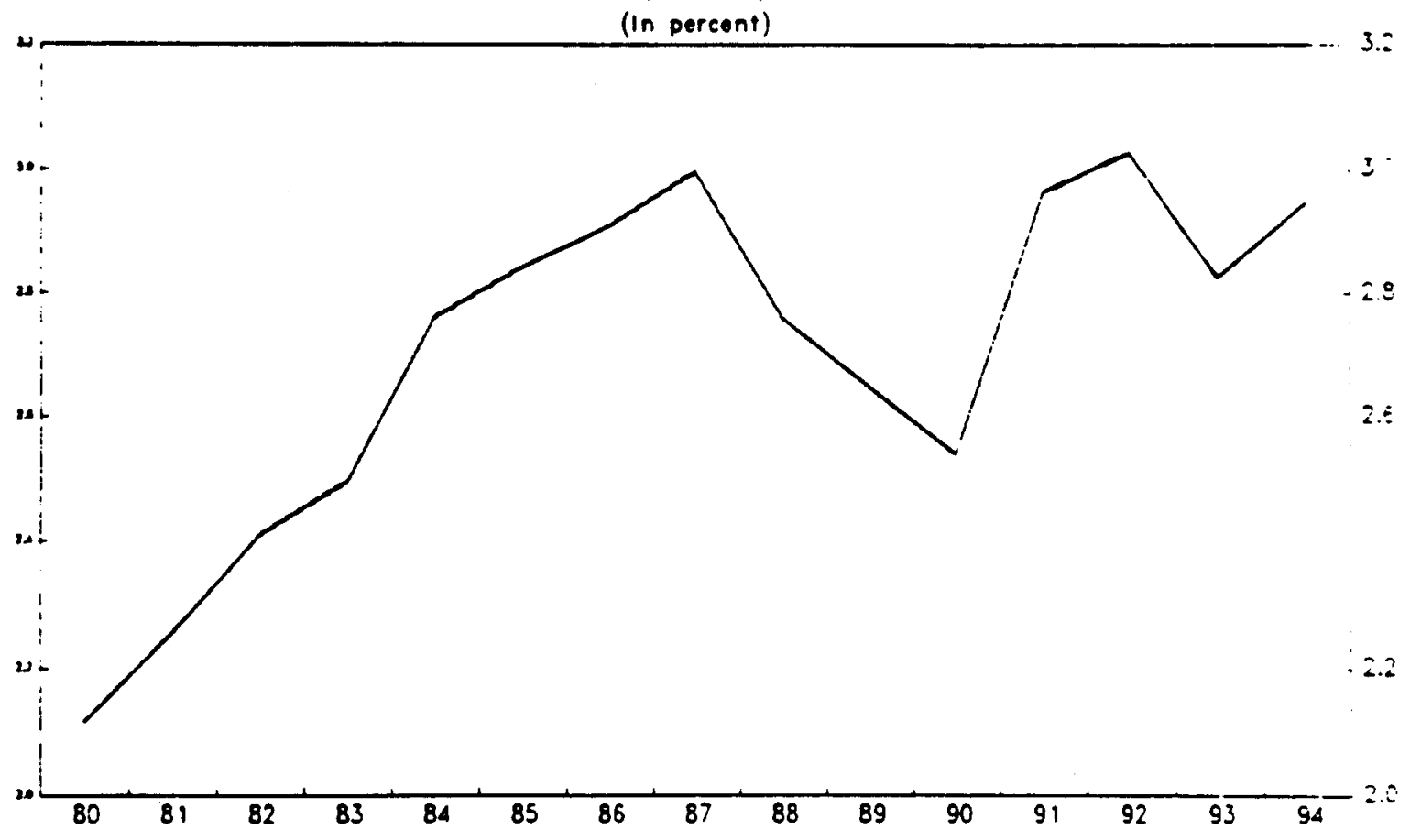

Sources: Centrol Bonk of Jordon: and staff estimates. 
This page intentionally left blank 


\section{The 1989-90 Bankine Crisis}

The collapse of a major bank in August 1989, the third largest banking institution in Jordan, together with the emergence of financial difficulties in six other financial institutions linked to it, put in jeopardy the integrity of Jordan's banking system. I The banking crisis emerged because of three main reasons: (1) an inadequate banking regulation; an overexposure of the banking system to the real estate market; and (iii) an imprudent speculation on foreign exchange.

One of the main reason explaining the emergence of a major banking crisis in the late 1980 s was the lack of a proper banking supervision and prudential regulation. The specialized financial institutions, which are long-term sectoral project oriented and, thus, likely to be exposed to risky intermediation, were not under the survelllance of the CBJ but supervised by their own sector ministries. The scope of the $C B J ' s$ surveillance was limited to ensuring commercial banks' compliance with five critical operating ratios and to approving any credit in excess of JD 500,000 granted by a commercial bank. However, this apparent prudent credit management seems to have been circumvented to discharge commercial banks from doing the proper risk credit analysis in their loan allocations. More importantly, the Jordanian accounting regulations concerning loan loss provisions was inefficient in early identifying non-performing assets since decisions to build provisions were usually delayed until after the final court decision on the destitute asset was rendered. These weaknesses in the regulatory framework resulted in widespread fraudulent practices and mismanagement that the monetary authorities falled to detect.

Loans collateralized with real estate property became non-performing with the slump in the real estate market in the late 1980s. In the aftermath of the second oil shock, Jordan registered large inflows of workers' remittances, which reached an all-time high of US\$1.3 billion (about 25 percent of GDP) in receipts from abroad in 1984; such injection of demand reverberated in a rapid expansion of the private sector construction activities, and exposure of the banking system. As speculative real estate activities collapsed in the late 1980s, together with the collateralized values of real estate loans, several banks were highly exposed with numerous nonperforming assets in their balance sheets.

Banks' excessive exposure on forelgn exchange position also contributed to this crisis. Before 1987, the JD was strictly pegged and fixed to the SDR in nominal terms. Starting in 1987 with the weakening of the balance of payment position, a parallel market for foreign exchange emerged and financial institutions were overexposed with high levels of foreign

1 The major bank accounted for more than 10 percent of the total assets of the banking system in 1989. Total bad assets was believed to represent up to 20-30 percent of total assets of the banking system. 
obligations. In several cases, speculative operations in the form of positions between the official and parallel exchange markets ended up in the loss of almost the entire foreign assets of the banks.

To preserve the security of the entire banking system from the systemic risk of chain failures, the CBJ had to inject US\$400-500 million (about 10 percent of the GDP in 1989) in the banking system through its overdraft facility to meet the run on insolvent banks' deposits and to settle some of their foreign obligations. This dramatic injection of liquidity was reflected in both the central bank's balance sheet and the monetary survey through the growth of the reserve money and the money and quasi-money aggregates. Both monetary aggregates increased by more than 15 percent in 1989 and contributed to fuel inflation, which peaked at 26 percent, at a time the real GDP was contracting by 13.5 percent. Since 1990 , the CBJ has started to recover gradually part of these unsecured assets and, by mid1994, 20 percent of the total cost of the bailout operations was recovered by the $\mathrm{CBJ}$.

In the wake of the banking crisis, the $C B J$ issued a number of additional regulatory measures aimed at enhancing its surveillance over the banking system. Speciflc measures governing loan loss provisioning, capital adequacy requirements, and portfollo management of commerclal banks had been enacted. As regards provisloning for bad loans, the guideline issued in 1992 required provisioning of 50 percent for loans for which banks have not received any payments for more than 180 days but less than one year; the required provisioning was 100 percent of the loan amount for loans for which the banks have not recelved payments for more than one year. or for which the banks had determined that no repayment would be expected. Regarding general provisioning for ordinary bank credit, the required provisioning would be 1-2 percent for direct credit facilities, and 0.25-0.50 percent for indirect credit facilities. The guideline also streamlined the procedure for notifying the $C B J$ in this regard. The regulations governing capital adequacy requirements of the commercial banks issued in 1992 essentially applied the Basles convention regarding capltal adequacy to Jordan's banking system.

A subsequent effect of the banking crisis has been to shift the composition of the assets hold by the private sector, either in cash or deposits, in favor of foreign exchange denominated assets. Actually, the combination of low nominal interest rates, high anticipated inflation, and the perception that further depreclation of the JD may follow contributed to a fall in the demand for JD-holdings. In 1989, about 30 percent of the increase in broad money was in the form of an increase in foreign currency deposits of residents, which in part reflected the valuation gains arising from the depreciation of the JD. 


\section{Monetary Program Under Indirect Monetary Control}

As part of their medium-term structural reform program, the Jordanian authorities moved from a system of direct credit controls $1 /$ to more market-based and indirect instruments of monetary control.

Under this new monetary environent, the monetary program aims at forecasting the balance sheet of the CBJ in two stages. The first stage consists of ascertaining the reserve money, consistent with the estimated money demand resulting from the overall macroeconomic baseline scenario (targeted growth, inflation, fiscal and external adjustments). The second stage essentially forecasts the rest of the CBJ's balance sheet, in order to project the volume of JD-denominated certificates of deposit (CDs) that the CBJ should auction to manage total liquidity in the banking system. The sequence by which the program is worked out is illustrated by the following relations:

(1) RM - MQM (targeted) / m (projected)

(2) NDA - RM - NIR (targeted)

(3) CDs - CREDg (targeted) + CREDbs (projected) + OIN (net) (projected) NDA

The first equation indicates the level of RM consistent with the projected money multiplier (m) and desired broad money supply MQM; the second Identity gives the level of the Central Bank's NDA consistent with the projected reserve money and targeted (or desired) level of net international reserves (NIR): finally, the third identity indicates the CBJ intervention on the CDs market through its sales and purchases consistent with: (i) the projected central bank's NDA; (1i) the targeted government borrowing at the CBJ (CREDg); (iii) the estimated anounts of rediscount at the CBJ's credit facility windows (CREDbs); and (iv) the projected changes in other items (net) (OIN). With respect to the conduct of monetary policy, the sequence is reversed: through 1 ts intervention on the CDs market and its control over government borrowing and the rediscount credit facilities, the CBJ aims at managing its NDA, $2 /$ consistent with the targeted NIR floor, so as to keep reserve money at levels conducive to the desired money supply.

1) The system of direct nonetary controls consisted of: (1) a maximum loan to deposit ratio of 90 percent; and (11) the 10 to 1 credit to capital ratio. These ratios were reinforced by limits on individual bank credit expansion introduced in late July 1993.

2 Net claims on government, claims on licensed banks, and JD-denominated CDs are the largest components of the CBJ's NDA. Other components of the CBJ's NDA are either known with certainty (e.g., capital accounts) or easily predictable (remunerated deposits, other items (net), and net claims on nonbanks). 


\section{Reserve money and money multiplier}

The money multiplier is estimated in line with the projections for public cash holdings, currency outside banks, banks' cash in vaults and legal and excess reserve requirements. The quarterly pattern should reflect (I) the projected cash to deposit seasonal pattern; (i1) all changes in the legal rates of reserve requirements; and (iii) the expected changes in commercial banks excess reserves at the CBJ. Consistent with che adjustment program in terms of growth, inflation and fiscal and external adjustments, the projected reserve money remains highly dependent on the quarterly demand for broad money. It is worth noting that the money demand function may be temporarily disrupted by the financial liberalization, as well as by recent developments and prospects in the West Bank and Gaza Strip.

\section{Other items of the balance sheet of the Central Bank}

For the indirect system of control to have its desired impact, it is important that the monetary authorities monitor closely the Central Bank's NDA, $W$ in particular goverment borrowing from the $C B J$ and the $C B J$ 's rediscount credit facilities, consistent with the targeted/desired level for net international reserves. $2 /$ On this basis, the $C B J$ would control the liquidity of the banking system through its auctioning of JD-denominated CDs and its intervention in the secondary market.

1. NDA of the CBJ is defined as the difference between the sum of: (i) claims on the Central Government (general and own budgets): (11) claims on the Social Security Corporation; (11i) claims on municipalities and local government; (iv) claims on public non-financial institutions; (v) claims on private sector; (vi) claims on licensed banks; (vi1) claims on other financial institutions; and (viii) unclassified assets; and the sum of:

(1) JD-denominated CDs; (ii) licensed banks' remunerated deposits with the CBJ; (111) deposit of the Central Government (general and own budgets); (iv) other public sector deposits; (v) deposits of financial institutions; (vi) deposits of the private sector; (vii) unclassified liabilities; and (vili) capital accounts. Alternatively, NDA of the $C B J$ is defined as the difference between reserve money and the CBJ's net international reserves.

2) Net international reserves consists of: (1) gold; (1i) IMF reserve position: (iii) purchases from the Fund; (iv) SDRs; (v) treasury bills and securities in foreign currencies; ( $v i$ ) balances and deposits in foreign currencies; (vii) bilateral accounts (net); and (viii) other deposits in foreign currencies less deposits of international institutions. The definition of NIR is equivalent to the definition of total CBJ's NFA, adjusted for purchases and repurchases from the Fund. 
Among the constituents of the NDA of the CBJ, net claims on the Central Government (CREDg) I/ are projected in line with (1) the contemplated fiscal adjustment and required central bank financing; $2 /$ and (ii) the seasonal pattern, which has been associated with govermment borrowing/ deposit at the $C B J$ in the past.

Consistent with the program objective of building up official foreign exchange reserves, the $C B J$ should gradually increase the stocix of gross foreign exchange reserves. $3 /$

Claims on the banking system (CREDbs) consist of the credit facilities at the $\mathrm{CBJ}$ 's rediscount windows and of the unsecured advances attached to the bailout of the bankrupt financial institutions during the 1980 s. First, concerning the rediscount facilities, the $C B J$ operates a standard rediscount facility at an interest rate of 8.5 percent; this facility has not been drawn upon since 1989 because of the comercial banks' excess liquidity. However, the shift toward market-based instruments for monetary control will probably make this facility more attractive to the banks when the excess liquidity is absorbed. The CBJ also operates two preferential credit facilities. Although these two facilities are of limited quantitative significance at present, $\underline{4}$ the $C B J$ should have to exercise strict quantitative control over access to its refinance and rediscount facilities, both on standard and preferential credit facilities, and rationalize the interest rates on these facilities. Second, with respect to the unsecured

1 Which consist mainly of the advances to the Government, the development bonds, and the treasury bills.

2) By law, the $C B J$ may grant an interest free ordinary advance to the Government up to 20 percent of domestic revenues as estimated in the general budget law. The $C B J$ may also extend a profit advance to the government from its share of net profits. As regards issuance of government bonds and treasury bills, the $C B J$ is not committed by law to buy any amount of the public debt issues. (The nominal value of bonds issued by the Government cannot exceed 20 percent of the actual capital expenditures of the previous year; that of treasury bills issued cannot exceed 25 percent of the average domestic revenues collected in the past three fiscal year, or of total currency in circulation, whichever is larger).

3) Defined as net international reserves excluding gold, foreign exchange deposits of residents at the $C B J$, and claims on the Central Bank of Iraq.

4) The CBJ charges 3.5 percent for its export credit facility on documentary credit ( 90 percent of the value of the credit may be rediscounted for a period of up to 18 months). The CBJ also operates a credit facility for specialized credit institutions (such as the Industrial Development Bank, the Housing Corporation, and the Agricultural Credit Corporation) for a period of up to five years. 
advances to those banks that experienced serious difficulties during the 1980s, 1 the CBJ may expect to gradually recover part of these unsecured assets.

The amount of JD-denominated CDs to auction is residually determined so as to balance the balance sheet of the Central Bank.

\section{Sensitivity of the monetary program to selected parameters}

The monetary program under indirect instruments of monetary control is likely to be highly sensitive to: (1) the achievenent of the program in terms of growth, Inflation and fiscal and external adjustments; (11) the process of financial liberalization and financial innovations; and (1ii) the monetary and banking developments and prospects in the West Bank and Gaza Strip (WBGS). In particular, the money multiplier (and thus the broad money supply) may become unstable because of the public behavior with respect to holding cash $2 /$ or the banks behavior with respect to building excess reserves. In addition, as experienced by countries that have recently switched to more market-based instruments for monetary control, 3 the demand for money function may not remain stable, at least during the transitional perlod. The use of the JD as a legal tender in the WBGS and the opening of banks dealing in JDs may contribute to this instability of the demand for money. In this regard, some fluctuations in the money multiplier and the reserve money may result from variations in three selected parameters: namely, the income money velocity, the ratio of cash to deposit, and the ratio of reserve requirements to deposits (Table 16).

A money demand income elasticity, which is 0.1 poine higher would require: (1) an additional Increase in money supply of about 1.1 percentage points: (ii) a supplenentary increase of reserve money of about 1 percentage point; and (111) consistent with the underlying level for NIR, the repurchase of some JD 22 million of CDs from the baseline scenario. Simllarly, a ratio of cash to deposits, which is 1 percentage point higher by the end-year would allow for an additional increase in reserve money of about 1.7 percentage points, and require the purchase of JD 27 millions CDs compared to the baseline scenario. More importantly, a decrease in the

1 Total injection of liquidity toward the restructuring of failed banks amounted to US\$400-500 million, of which the Petra Bank alone accounted for US\$300 million.

2) The currency to deposit ratio is likely to vary for economic reasons, including in particular the opportunity cost of holding cash, but also for political reasons, especially confidence in the peace process and the development of a sound banking system in the WBGS.

3) See for example, Einancial Liberalization. Money Demand and Monetary Policy in Asian Countries, by W. Tseng, and R. Corker, IMF's Occasional Paper 84, 1991. 
Table 16. Jordan : Sensitivity of the Monetary Program to Selected Parameters

\begin{tabular}{|c|c|c|c|c|}
\hline & $\begin{array}{r}\text { Money } \\
\text { multiplier }\end{array}$ & $\begin{array}{l}\text { Change in } \\
\text { reserve money }\end{array}$ & $\begin{array}{l}\text { Change in } \\
\text { money demand }\end{array}$ & $\begin{array}{r}\text { Sales of } \\
\text { CDs (net) }\end{array}$ \\
\hline Baseline scenario (program) & 3.02 & 5.70 & 12.30 & 84 \\
\hline \multicolumn{5}{|l|}{ Elementary simulation $1 /$ : } \\
\hline $\begin{array}{l}\text { Income elasicity of money demand } 2 \text { / } \\
\text { Cash to deposit ratio } 3 / \\
\text { Reserve requirement } 4 \text { / }\end{array}$ & $\begin{array}{r}-\overline{0.04} \\
0.08\end{array}$ & $\begin{array}{r}1.0 \\
1.7 \\
-2.5\end{array}$ & $\begin{array}{l}1.1 \\
-- \\
--\end{array}$ & $\begin{array}{r}-12 \\
-27 \\
40\end{array}$ \\
\hline
\end{tabular}

Source: Staff estimates.

1/ Different from baseline scenario.

2/ Income elasticity of money demand 0.1 higher.

3/ Cash to deposit ratio 1 point higher.

4/ Reserve requirement (legal or excess) I point lower. 
ratio of reserves to deposits (either in legal or excess reserves) would imply a lower reserve money growth of about 2.5 percentage point (compared to the baseline) and the auction of an additional JD 40 millions of CDs. 


\section{Social Security Corporation}

The Social Security Corporation (SSC) has been set up in 1980 in order to provide social insurance for old-age pensions, survivor pensions, disability pensions, work accidents and vocational diseases for nongovernment workers. The scheme is mandatory for companies with 5 employees or more and voluntarily for others. About 9,000 companies are enrolled, totalling some 275,000 contributors. Contributions are equivalent to 15 percent of gross wage, 10 percent being paid by the employer and 5 percent by the employee. The overall number of beneficiaries is currently about 23,000.

The benefit formula for old-age pensions is based on the average salary over the last two years of activity, multiplied by 2 percent times the number of years of contributions. Once pensions are paid out, there is no subsequent cost-of-living adjustment. There is a minimum pension of JD 50 per month. Given that the SSC has been established.recently, the average number of contributing years is limited; therefore, about 90 percent of the recipients take advantage of the minimum pension provision. Old-age pensions are supplemented with family allowances equivalent to 10 percent for the spouse and 5 percent per dependent child below the age of 26 , with a maximum of two. The retirenent age is 60 for males and 55 for females. Early retirement, with a limited penalty in pension formula, is allowed from the age of 45 if the applicant has contributed for at least 15 years. For work accidents and vocational diseases, the benefit is equivalent to 60 percent of the last salary; for survivor pensions, it is 50 percent of the last salary.

For the time being, the financial position of the SSC appears to be strong (Table 17). However, this is largely due to the fact that SSC is a new establishment, resulting in a ratio of contributors to beneficiarles of above ten. Current arrangenents, in particular regarding early retirement and the minimum pension provision, may appear in the long run to be too generous or requiring transfers from the budget to maintain the fully-funded nature of the SSC pension schene. If the SSC turns out to be only partially funded, changes in denographic trends, in particular lower population growth rate and increased $11 f e$ expectancy, will affect the long-term sustainability of the current scheme. With the increase over time in the average number of contributing years, the relative weight of the minimum pension provision should decrease. On the other hand, given the absence of cost-of-living adjustment, pressures to increase the mininum pension amount are likely to remain strong. Another source of concern is related to the return on investment. The SSC scheme is based on so-called defined-benefit principle, 1.e., beneficiaries do not share the risk on investment. With this respect, investment in operations owned/controlled by the Government (particularly, if the public enterprises are not most efficient), as it happened in the past, may not be the most judicious. 
Table 17. Jordan: Assets and Liabilities of the Social Security Corporation, 1987-91

(Millions of JDs)

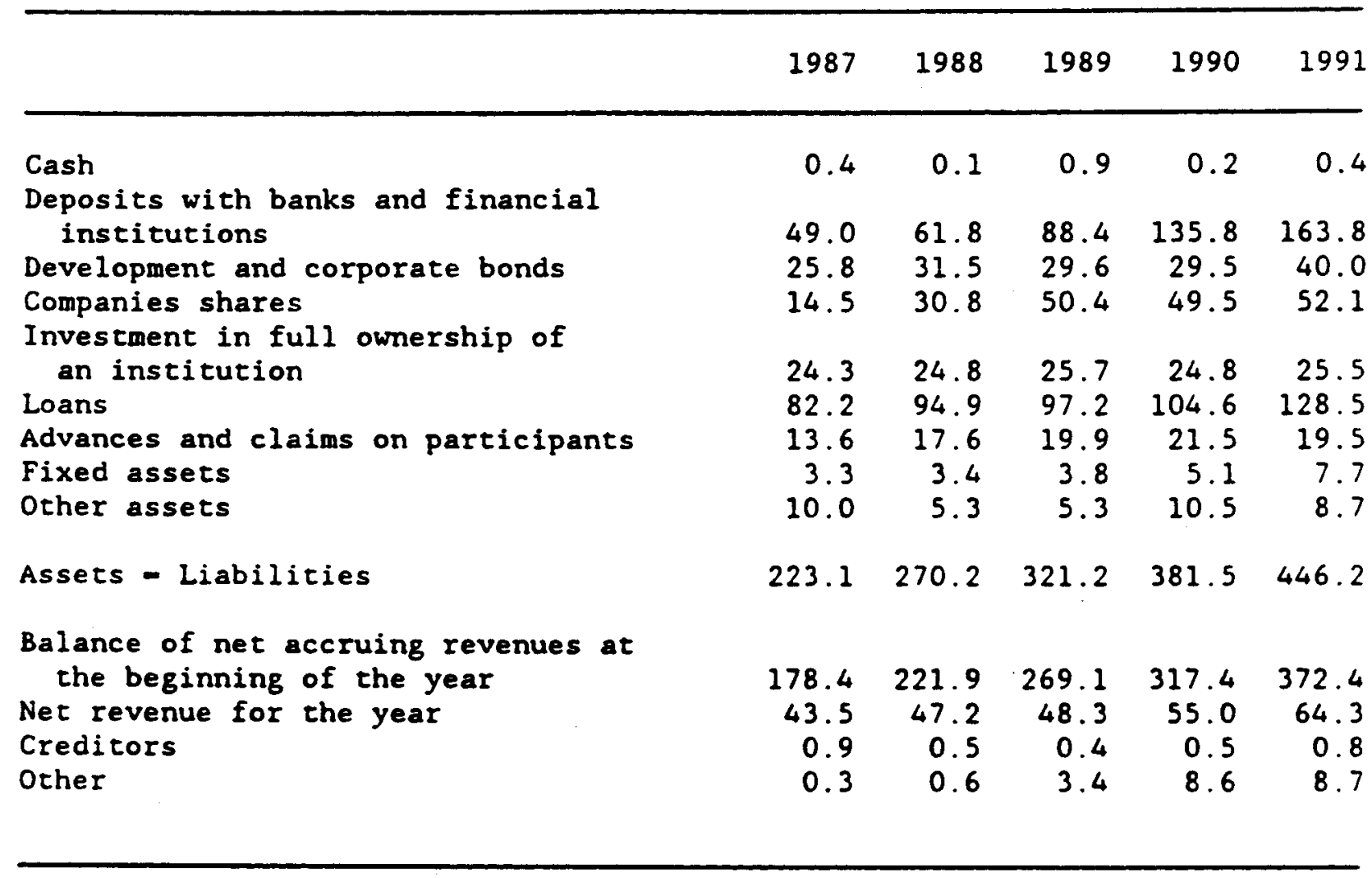

Source: Social Security Corporation. 
Table 18. Jordan: Industrial Origin of Gross Domestic Product at Current Prices, 1989-94

\begin{tabular}{|c|c|c|c|c|c|c|}
\hline & 1989 & 1990 & 1991 & 1992 & $\frac{\text { Est. }}{1993}$ & $\frac{\text { Est. }}{1994}$ \\
\hline & \multicolumn{6}{|c|}{ (In millions of Jordan dinars) } \\
\hline $\begin{array}{l}\text { Agriculture } \\
\text { Mining } \\
\text { Manufacturing } \\
\text { Electricity and water } \\
\text { Construction } \\
\text { Trade } \\
\text { Transport and communications } \\
\text { Government services } \\
\text { Other services } 1 /\end{array}$ & $\begin{array}{r}139.8 \\
154.5 \\
254.7 \\
52.7 \\
101.5 \\
180.7 \\
359.1 \\
431.3 \\
435.3\end{array}$ & $\begin{array}{r}187.8 \\
148.8 \\
345.3 \\
53.9 \\
105.6 \\
216.8 \\
362.0 \\
449.1 \\
455.2\end{array}$ & $\begin{array}{r}213.5 \\
124.9 \\
343.7 \\
62.0 \\
125.7 \\
254.7 \\
382.7 \\
474.4 \\
524.0\end{array}$ & $\begin{array}{r}246.9 \\
130.5 \\
406.3 \\
66.6 \\
215.3 \\
278.7 \\
450.0 \\
554.7 \\
611.9\end{array}$ & $\begin{array}{r}274.3 \\
110.2 \\
451.0 \\
70.7 \\
251.9 \\
312.1 \\
495.0 \\
643.5 \\
692.5\end{array}$ & $\begin{array}{r}288.1 \\
112.4 \\
520.0 \\
77.5 \\
269.6 \\
352.7 \\
569.3 \\
694.9 \\
737.6\end{array}$ \\
\hline \multirow[t]{2}{*}{$\begin{array}{l}\text { GDP at factor costs } \\
\text { Net indirect taxes } \\
\text { GDP at market prices } \\
\text { Net factor income from abroad } \\
\text { GNP at market prices }\end{array}$} & $\begin{array}{r}2,109.6 \\
262.5 \\
2,372.1 \\
-123.5 \\
2,248.6\end{array}$ & $\begin{array}{r}2,324.5 \\
343.8 \\
2,668.3 \\
-239.5 \\
2,428.8\end{array}$ & $\begin{array}{r}2,505.6 \\
349.5 \\
2,855.1 \\
-221.1 \\
2,634.0\end{array}$ & $\begin{array}{r}2,960.9 \\
532.1 \\
3,493.0 \\
-186.2 \\
3,306.8\end{array}$ & $\begin{array}{r}3,301.2 \\
581.3 \\
3,882.5 \\
-149.1 \\
3,733.4\end{array}$ & $\begin{array}{r}3,622.1 \\
644.1 \\
4,266.2 \\
-132.0 \\
4,134.2\end{array}$ \\
\hline & \multicolumn{6}{|c|}{ (In percent of GDP at factor costs) } \\
\hline $\begin{array}{l}\text { Agriculture } \\
\text { Mining } \\
\text { Manufacturing } \\
\text { Electricity and water } \\
\text { Construction } \\
\text { Trade } \\
\text { Transport and communications } \\
\text { Government services } \\
\text { Other services } y\end{array}$ & $\begin{array}{r}6.6 \\
7.3 \\
12.1 \\
2.5 \\
4.8 \\
8.6 \\
17.0 \\
20.4 \\
20.6\end{array}$ & $\begin{array}{r}8.1 \\
6.4 \\
14.9 \\
2.3 \\
4.5 \\
9.3 \\
15.6 \\
19.3 \\
19.6\end{array}$ & $\begin{array}{r}8.5 \\
5.0 \\
13.7 \\
2.5 \\
5.0 \\
10.2 \\
15.3 \\
18.9 \\
20.9\end{array}$ & $\begin{array}{r}8.3 \\
4.4 \\
13.7 \\
2.2 \\
7.3 \\
9.4 \\
15.2 \\
18.7 \\
20.7\end{array}$ & $\begin{array}{r}8.3 \\
3.3 \\
13.7 \\
2.1 \\
7.6 \\
9.5 \\
15.0 \\
19.5 \\
21.0\end{array}$ & $\begin{array}{r}8.0 \\
3.1 \\
14.4 \\
2.1 \\
7.4 \\
9.7 \\
15.7 \\
19.2 \\
20.4\end{array}$ \\
\hline GDP at factor costs & 100.0 & 100.0 & 100.0 & 100.0 & 100.0 & 100.0 \\
\hline
\end{tabular}

Source: Department of Statistics

y Comprising finance, insurance, real estate, and busineas services; community, social, and personal services; nonprofit services to households; and an imputed bank service charge. 
Table 19. Jordan: Industrial Origin of Gross Domestic Product

at Constant 1985 Prices, 1989-94

\begin{tabular}{|c|c|c|c|c|c|c|}
\hline & 1989 & 1990 & 1991 & 1992 & $\frac{\text { Est. }}{1993}$ & $\frac{\text { Est. }}{1994}$ \\
\hline & \multicolumn{6}{|c|}{ (In millions of Jordan dinars) } \\
\hline $\begin{array}{l}\text { Agriculture } \\
\text { Mining } \\
\text { Manufacturing } \\
\text { Electricity and water } \\
\text { Construction } \\
\text { Trade } \\
\text { Transport and communications } \\
\text { Government services } \\
\text { Other services } y\end{array}$ & $\begin{array}{r}124.4 \\
77.4 \\
204.4 \\
69.4 \\
86.1 \\
77.1 \\
279.9 \\
388.2 \\
373.6\end{array}$ & $\begin{array}{r}163.1 \\
63.6 \\
224.0 \\
53.3 \\
80.7 \\
57.7 \\
270.2 \\
386.1 \\
363.5\end{array}$ & $\begin{array}{r}178.7 \\
54.1 \\
220.7 \\
56.2 \\
89.2 \\
59.0 \\
255.1 \\
392.6 \\
399.4\end{array}$ & $\begin{array}{r}209.6 \\
53.5 \\
253.7 \\
58.7 \\
138.6 \\
65.4 \\
278.5 \\
415.3 \\
438.3\end{array}$ & $\begin{array}{r}230.6 \\
52.1 \\
269.0 \\
61.1 \\
155.2 \\
70.0 \\
292.5 \\
440.2 \\
459.8\end{array}$ & $\begin{array}{r}232.9 \\
52.6 \\
294.0 \\
65.0 \\
161.5 \\
75.6 \\
324.6 \\
457.9 \\
478.3\end{array}$ \\
\hline \multirow[t]{2}{*}{$\begin{array}{l}\text { GDP at factor costs } \\
\text { Net indirect taxes } \\
\text { GDP at market prices }\end{array}$} & $\begin{array}{r}1,680.5 \\
209.1 \\
1,889.6\end{array}$ & $\begin{array}{r}1,662.2 \\
245.8 \\
1,908.0\end{array}$ & $\begin{array}{r}1,705.0 \\
237.8 \\
1,942.8\end{array}$ & $\begin{array}{r}1,911.6 \\
343.5 \\
2,255.1\end{array}$ & $\begin{array}{r}2,030.5 \\
354.5 \\
2,385.0\end{array}$ & $\begin{array}{r}2,142.3 \\
378.6 \\
2,520.9\end{array}$ \\
\hline & \multicolumn{6}{|c|}{ (Annual changes in percent) } \\
\hline $\begin{array}{l}\text { Agriculture } \\
\text { Mining } \\
\text { Manufacturing } \\
\text { Electricity and water } \\
\text { Construction } \\
\text { Trade } \\
\text { Transpon and communications } \\
\text { Government services } \\
\text { Other services } 1 /\end{array}$ & $\begin{array}{r}-24.5 \\
10.6 \\
24.0 \\
10.0 \\
-20.5 \\
-65.9 \\
-3.1 \\
-4.1 \\
-3.2\end{array}$ & $\begin{array}{r}31.1 \\
-17.8 \\
9.6 \\
-23.2 \\
-6.3 \\
-25.2 \\
-3.5 \\
-0.5 \\
-2.7\end{array}$ & $\begin{array}{r}9.6 \\
-14.9 \\
-1.5 \\
5.5 \\
10.5 \\
2.3 \\
-5.6 \\
1.7 \\
9.9\end{array}$ & $\begin{array}{r}17.3 \\
-1.1 \\
15.0 \\
4.4 \\
55.4 \\
10.8 \\
9.2 \\
5.8 \\
9.7\end{array}$ & $\begin{array}{r}10.0 \\
-2.6 \\
6.0 \\
4.1 \\
12.0 \\
7.0 \\
5.0 \\
6.0 \\
4.9\end{array}$ & $\begin{array}{r}1.0 \\
1.0 \\
9.3 \\
6.4 \\
4.1 \\
8.0 \\
11.0 \\
4.0 \\
4.0\end{array}$ \\
\hline $\begin{array}{l}\text { GDP at factor costs } \\
\text { Net indirect taxes } \\
\text { GDP at market prices }\end{array}$ & $\begin{array}{l}-10.5 \\
-21.8 \\
-13.4\end{array}$ & $\begin{array}{r}-1.1 \\
17.6 \\
1.0\end{array}$ & $\begin{array}{r}2.6 \\
-3.3 \\
1.8\end{array}$ & $\begin{array}{l}12.1 \\
44.4 \\
16.1\end{array}$ & $\begin{array}{l}6.2 \\
3.2 \\
5.8\end{array}$ & $\begin{array}{l}5.5 \\
6.8 \\
5.7\end{array}$ \\
\hline
\end{tabular}

Source: Department of Statistics.

y Comprising finance, insurance, real estate, and business services; community, social, and personal services; nonprofit services to households; domestic services of households; and an imputed bank service charge. 
Table 20. Jordan: National Expenditure Accounts in Current Prices, 1989-94

\begin{tabular}{|c|c|c|c|c|c|c|}
\hline & 1989 & 1990 & 1991 & 1992 & $\frac{\text { Est. }}{1993}$ & $\frac{\text { Est. }}{1994}$ \\
\hline & \multicolumn{6}{|c|}{ (In millions of Jordan dinars) } \\
\hline $\begin{array}{l}\text { Total consumption } \\
\text { Public } \\
\text { Private }\end{array}$ & $\begin{array}{r}2,253.9 \\
618.8 \\
1,635.1\end{array}$ & $\begin{array}{r}2,6 \times 0.3 \\
663.9 \\
1,976.4\end{array}$ & $\begin{array}{r}2,781.6 \\
742.0 \\
2,039.6\end{array}$ & $\begin{array}{r}4,349.0 \\
790.6 \\
2,648.4\end{array}$ & $\begin{array}{r}3,837.1 \\
852.1 \\
2,985.0\end{array}$ & $\begin{array}{r}4,125.0 \\
921.5 \\
3,203.5\end{array}$ \\
\hline $\begin{array}{l}\text { Gross fived investment } \\
\text { Buildings \& construction } \\
\text { Machines and equipment }\end{array}$ & $\begin{array}{l}554.1 \\
375.6 \\
171.8\end{array}$ & $\begin{array}{l}694.0 \\
436.0 \\
258.0\end{array}$ & $\begin{array}{l}678.0 \\
476.3 \\
201.7\end{array}$ & $\begin{array}{r}1,0492 \\
811.3 \\
237.9\end{array}$ & $\begin{array}{r}1,235.0 \\
948.6 \\
286.4\end{array}$ & $\begin{array}{r}1,168.9 \\
818.3 \\
350.7\end{array}$ \\
\hline Final domestic demand & $2,808.0$ & 3,3343 & $3,459.6$ & $4,488.2$ & $5,072.1$ & $5,294.4$ \\
\hline Change in stocks & 9.1 & 156.2 & 60.5 & 159.6 & -- & -473 \\
\hline Total domestic demand & $2,817.1$ & $3,490.5$ & $3,520.1$ & $4,647.8$ & $5,072.1$ & $5,251.3$ \\
\hline $\begin{array}{l}\text { Net exports of goods and } \\
\text { nonfactor services } \\
\text { Exports } \\
\text { Imports }\end{array}$ & $\begin{array}{l}-444.9 \\
1,359.5 \\
1,804.4\end{array}$ & $\begin{array}{r}-822.4 \\
1,652.1 \\
-2,474.3\end{array}$ & $\begin{array}{r}-665.1 \\
1,697.5 \\
-2,362.6\end{array}$ & $\begin{array}{r}-1,154.8 \\
1,819.9 \\
-2,974.7\end{array}$ & $\begin{array}{r}-1,189.6 \\
1,962.1 \\
-3,151.7\end{array}$ & $\begin{array}{l}-985.1 \\
2,085.7 \\
3,070.8\end{array}$ \\
\hline GDP at market prices & 2,3722 & $2,668.3$ & $2,855.0$ & $3,493.0$ & 3,8825 & $4,266.2$ \\
\hline Net factor income from abroad & -1235 & -239.5 & -221.1 & -186.2 & -149.1 & -132.0 \\
\hline GNP at market prices & $2,248.7$ & $2,428.8$ & $\begin{array}{r}2,633.9 \\
\text { (In pe }\end{array}$ & $\begin{array}{r}3,306.8 \\
\text { cent of GD } \\
\end{array}$ & $3,733.4$ & $4,117.1$ \\
\hline $\begin{array}{l}\text { Total consumption } \\
\text { Public } \\
\text { Private }\end{array}$ & $\begin{array}{l}95.0 \\
26.1 \\
68.9\end{array}$ & $\begin{array}{l}99.0 \\
24.9 \\
74.1\end{array}$ & $\begin{array}{l}97.4 \\
26.0 \\
71.4\end{array}$ & $\begin{array}{l}98.5 \\
22.6 \\
75.8\end{array}$ & $\begin{array}{l}98.8 \\
21.9 \\
76.9\end{array}$ & $\begin{array}{l}96.7 \\
21.6 \\
75.1\end{array}$ \\
\hline $\begin{array}{l}\text { Groes fixed investment } \\
\text { Buildings and coastructions } \\
\text { Machines and equipment }\end{array}$ & $\begin{array}{r}23.4 \\
15.8 \\
72\end{array}$ & $\begin{array}{r}26.0 \\
16.3 \\
9.7\end{array}$ & $\begin{array}{r}23.7 \\
16.7 \\
7.1\end{array}$ & $\begin{array}{r}30.0 \\
23.2 \\
6.8\end{array}$ & $\begin{array}{r}31.8 \\
24.4 \\
7.4\end{array}$ & $\begin{array}{r}27.4 \\
19.2 \\
8.2\end{array}$ \\
\hline $\begin{array}{l}\text { Net exports of goods } \\
\text { and nonfactor services } \\
\text { Export } \\
\text { Imports }\end{array}$ & $\begin{array}{r}573 \\
-76.1\end{array}$ & $\begin{array}{r}61.9 \\
-92.7\end{array}$ & $\begin{array}{r}59.5 \\
-82.8\end{array}$ & $\begin{array}{r}52.1 \\
-85.2\end{array}$ & $\begin{array}{r}50.5 \\
-812\end{array}$ & $\begin{array}{r}48.9 \\
-72.0\end{array}$ \\
\hline $\begin{array}{l}\text { Memorandum items: } \\
\text { Gross domestic savings (percent) }\end{array}$ & 5.0 & 1.0 & 2.6 & 1.5 & 1.2 & 3.3 \\
\hline
\end{tabular}

Source: Department of Statistics. 
Table 21. Jordan: Agricultural Production, 1989-94

(In thousands of metric tons)

\begin{tabular}{|c|c|c|c|c|c|c|}
\hline & 1989 & 1990 & 1991 & 1992 & 1993 & $\begin{array}{l}\text { Prelim. } \\
\text { Actuals } \\
1994\end{array}$ \\
\hline $\begin{array}{l}\text { Field crops } \\
\text { Wheat } \\
\text { Barley } \\
\text { Tobacco } \\
\text { Lentils } \\
\text { Other }\end{array}$ & $\begin{array}{r}54.5 \\
20.6 \\
2.9 \\
1.6 \\
\ldots\end{array}$ & $\begin{array}{r}82.9 \\
42.4 \\
2.9 \\
4.1 \\
\ldots\end{array}$ & $\begin{array}{r}117.5 \\
61.8 \\
39.9 \\
1.3 \\
1.2 \\
13.3\end{array}$ & $\begin{array}{r}172.3 \\
75.4 \\
68.9 \\
3.2 \\
2.8 \\
22.0\end{array}$ & $\begin{array}{r}123.1 \\
67.8 \\
44.3 \\
2.5 \\
3.4 \\
5.1\end{array}$ & $\begin{array}{r}100.0 \\
57.4 \\
34.2 \\
2.2 \\
2.3 \\
3.9\end{array}$ \\
\hline $\begin{array}{l}\text { Vegetables } \\
\text { Tomatoes } \\
\text { Eggplants } \\
\text { Cucumbers } \\
\text { Cauliflower and } \\
\text { cabbage } \\
\text { Melons } \\
\text { Other }\end{array}$ & $\begin{array}{r}250.4 \\
43.8 \\
53.1 \\
23.7 \\
66.7 \\
\ldots\end{array}$ & $\begin{array}{r}376.9 \\
59.5 \\
54.3 \\
44.3 \\
80.5 \\
\ldots\end{array}$ & $\begin{array}{r}697.2 \\
275.5 \\
61.1 \\
56.2 \\
40.9 \\
94.3 \\
169.2\end{array}$ & $\begin{array}{r}878.1 \\
490.3 \\
49.4 \\
34.2 \\
\\
30.7 \\
90.3 \\
183.2\end{array}$ & $\begin{array}{r}1,363.3 \\
621.4 \\
70.4 \\
100.6 \\
\\
77.0 \\
145.0 \\
348.9\end{array}$ & $\begin{array}{r}1,119.2 \\
491.0 \\
43.7 \\
82.4 \\
\\
72.0 \\
139.7 \\
290.4\end{array}$ \\
\hline $\begin{array}{l}\text { Fruits } \\
\text { Olives } \\
\text { Grapes } \\
\text { Citrus } \\
\text { Bananas } \\
\text { Other }\end{array}$ & $\begin{array}{r}25.7 \\
21.8 \\
166.7 \\
13.4 \\
\ldots\end{array}$ & $\begin{array}{r}63.7 \\
45.7 \\
154.1 \\
18.9 \\
\ldots\end{array}$ & $\begin{array}{r}284.5 \\
40.6 \\
39.1 \\
151.9 \\
26.3 \\
26.6\end{array}$ & $\begin{array}{r}346.5 \\
81.8 \\
50.2 \\
160.3 \\
11.5 \\
42.7\end{array}$ & $\begin{array}{r}365.3 \\
49.3 \\
54.8 \\
175.8 \\
18.4 \\
67.0\end{array}$ & $\begin{array}{r}456.4 \\
96.5 \\
53.8 \\
194.3 \\
20.9 \\
90.9\end{array}$ \\
\hline $\begin{array}{l}\text { Animal production } \\
\text { Red meat } \\
\text { Poultry meat } \\
\text { Milk } \\
\text { Eggs (million eggs) }\end{array}$ & $\begin{array}{r}9.4 \\
54.0 \\
69.4 \\
350.0\end{array}$ & $\begin{array}{r}10.1 \\
49.0 \\
96.4 \\
530.0\end{array}$ & $\begin{array}{r}16.8 \\
70.0 \\
156.2 \\
708.0\end{array}$ & $\begin{array}{r}16.5 \\
80.0 \\
156.0 \\
775.0\end{array}$ & $\begin{array}{r}18.9 \\
83.4 \\
166.6 \\
862.2\end{array}$ & $\begin{array}{r}16.1 \\
94.0 \\
151.4 \\
871.0\end{array}$ \\
\hline
\end{tabular}

Source: Department of Statistics. 
Table 22 Jordan: Output by Major Indvaries, 1999-94

\begin{tabular}{|c|c|c|c|c|c|c|c|}
\hline & Units & 1999 & 1990 & 1991 & 1992 & 1993 & 1994 \\
\hline $\begin{array}{l}\text { Phouphate } \\
\text { Potench } \\
\text { Fertiliners } \\
\text { Cemeat 1 } \\
\text { Petroleum products } \\
\text { Sole beather and wool } \\
\text { Upper leather } \\
\text { Detergents } \\
\text { Liquid batteries } \\
\text { Cigrettes }\end{array}$ & $\begin{array}{l}1,000 \text { ton } \\
1,000 \text { ton } \\
1,000 \text { ton } \\
1,000 \text { ton } \\
1,000 \text { ton } \\
\text { Ton } \\
1,000 \text { \&q it } \\
1,000 \text { too } \\
1,000 \text { betteries } \\
\text { Million cigarettes }\end{array}$ & $\begin{array}{r}6,635.6 \\
1,350.7 \\
602.7 \\
1,930.0 \\
2,335.1 \\
76.9 \\
1,804.1 \\
25.4 \\
68.4 \\
2,791.8\end{array}$ & $\begin{array}{r}5,748.1 \\
1,415.1 \\
595.8 \\
2,796.5 \\
2,993.8 \\
87.9 \\
1,878.3 \\
325 \\
595 \\
3,184.8\end{array}$ & $\begin{array}{r}4,460.8 \\
1,451.1 \\
602.1 \\
2,751.5 \\
2,307.2 \\
34.2 \\
2,264.2 \\
39.9 \\
85.1 \\
3,718.5\end{array}$ & $\begin{array}{r}4295.9 \\
1260.8 \\
553.6 \\
2,746.0 \\
2,839.6 \\
49.0 \\
2,639.7 \\
34.3 \\
86.7 \\
3,091.0\end{array}$ & $\begin{array}{r}4221.8 \\
1,370.1 \\
469.9 \\
3,078.9 \\
2,814.5 \\
59.3 \\
2,587.1 \\
32.4 \\
77.4 \\
3,465.0\end{array}$ & $\begin{array}{r}4217.9 \\
1,550.3 \\
749.7 \\
3,076.0 \\
2,917.9 \\
49.5 \\
2,196.4 \\
23.5 \\
724 \\
4,114.5\end{array}$ \\
\hline $\begin{array}{l}\text { beverages } \\
\text { Pepper and cardboand } \\
\text { Electricity } \\
\text { Iron } \\
\text { Textiles } \\
\text { Fodder }\end{array}$ & $\begin{array}{l}1,000 \text { liter } \\
1,000 \text { too } \\
\text { Million kwt } \\
1,000 \text { ton } \\
1,000 \text { yard } \\
1,000 \text { ton }\end{array}$ & $\begin{array}{r}5,432.3 \\
223 \\
3,061.5 \\
176.5 \\
1,617.7 \\
50.8\end{array}$ & $\begin{array}{r}6,814.4 \\
22.6 \\
3224.8 \\
179.1 \\
1,436.7 \\
47.0\end{array}$ & $\begin{array}{r}6,280.4 \\
21.2 \\
3,395.0 \\
200.3 \\
1,084.1 \\
47.4\end{array}$ & $\begin{array}{r}6,285.1 \\
17.0 \\
4,062.8 \\
234.7 \\
1,100.8 \\
53.5\end{array}$ & $\begin{array}{r}6,572.1 \\
16.0 \\
4,435.2 \\
181.4 \\
1,142.0 \\
43.7\end{array}$ & $\begin{array}{r}6,453.6 \\
17.6 \\
4,728.1 \\
156.7 \\
1,051.9 \\
502\end{array}$ \\
\hline $\begin{array}{l}\text { Index of indumerial } \\
\text { production }(1979=100) \\
\text { Percentage change }\end{array}$ & & $\begin{array}{r}1029 \\
5.0\end{array}$ & $\begin{array}{r}107.0 \\
4.0\end{array}$ & $\begin{array}{r}1003 \\
-6.3\end{array}$ & $\begin{array}{r}113.3 \\
13.0\end{array}$ & $\begin{array}{r}1272 \\
7.9\end{array}$ & $\begin{array}{r}129.1 \\
5.6\end{array}$ \\
\hline
\end{tabular}

Source: Central Bank of Jordan.

y locluding clinker in 1990-94. 
Table 23. Jorden: Consuruction Activity in Jorden, 1989-94

(Area in thousands of equare meters)

\begin{tabular}{|c|c|c|c|c|c|c|}
\hline \multirow[b]{2}{*}{ Year } & \multicolumn{2}{|c|}{ Recideatial } & \multicolumn{2}{|c|}{ Others } & \multicolumn{2}{|c|}{ Total } \\
\hline & $\begin{array}{l}\text { Permits } \\
\text { ineved }\end{array}$ & Area & $\begin{array}{l}\text { Permits } \\
\text { iscued }\end{array}$ & Area & $\begin{array}{l}\text { Permits } \\
\text { issued }\end{array}$ & Area \\
\hline 1989 & 9,427 & $2,130.4$ & 254 & 293.9 & 9,581 & $2,424.3$ \\
\hline 1990 & 11,691 & $2,477.5$ & 130 & 181.0 & 11.821 & $2,658.5$ \\
\hline 1991 & 17,160 & $4,261.7$ & 89 & 1102 & 17,249 & $4,371.9$ \\
\hline 1992 & 21,180 & $6,459.0$ & 11 & 37.5 & 21,191 & $6,496.5$ \\
\hline 1993 (Prelim) & 14,285 & $3,071.5$ & 2,184 & $1,134.0$ & 16,469 & $4,205.5$ \\
\hline 1994 (Prelim) & & & & & & \\
\hline
\end{tabular}

Sources: Municipalities of Greater Amman, Irbid, and Zarqa; Association of Jordan Engineers; and Department of Statictica. 
Table 24. Jordan: New Registrationa and Capital Investment, 1989-94

\begin{tabular}{|c|c|c|c|c|c|c|c|c|c|c|c|c|}
\hline \multirow[b]{2}{*}{ Sectons } & \multicolumn{2}{|c|}{1909} & \multicolumn{2}{|c|}{$19 \%$} & \multicolumn{2}{|c|}{1991} & \multicolumn{2}{|c|}{1992} & \multicolumn{2}{|c|}{1993} & \multicolumn{2}{|c|}{1994} \\
\hline & $\begin{array}{l}\text { Number of } \\
\text { companies }\end{array}$ & $\begin{array}{l}\text { Capital } \\
\text { JD mill. }\end{array}$ & $\begin{array}{l}\text { Number of } \\
\text { compenies }\end{array}$ & $\begin{array}{l}\text { Capital } \\
\text { JD aill. }\end{array}$ & $\begin{array}{l}\text { Number of } \\
\text { compenies }\end{array}$ & $\begin{array}{l}\text { Capital } \\
\text { JD mill. }\end{array}$ & $\begin{array}{l}\text { Number of } \\
\text { compenice }\end{array}$ & $\begin{array}{l}\text { Capital } \\
\text { JD mill. }\end{array}$ & $\begin{array}{l}\text { Number of } \\
\text { companies }\end{array}$ & $\begin{array}{l}\text { Copital } \\
\text { JD mill. }\end{array}$ & $\begin{array}{l}\text { Number of } \\
\text { companiea }\end{array}$ & $\begin{array}{l}\text { Capital } \\
\text { JD mill. }\end{array}$ \\
\hline Agricullure & 13 & 0.3 & 8 & 0.2 & 17 & 0.4 & 19 & 1.6 & 21 & 2.5 & 10 & 0.5 \\
\hline Industry & 404 & 19.0 & 488 & 23.0 & 710 & 46.5 & $813 y$ & 101.0 & 849 ? & 122.3 & 649 & 183.3 \\
\hline Construction & 49 & 3.1 & 49 & 1.5 & 126 & 4.8 & 177 & 8.2 & 140 & 8.1 & 145 & 11.1 \\
\hline Trade & 928 & 82 & 1,318 & 10.0 & 2,329 & 26.0 & 2,447 & 27.0 & $2,241 \mathrm{y}$ & 33.1 & 3,302 & 73.0 \\
\hline Other services & 450 & 41.7 & 530 & 17.8 & 963 & 16.3 & 1,100 & 24.8 & $1,337 y$ & $\mathbf{5 2 . 0}$ & 1,347 & 141.5 \\
\hline Total & 1,844 & $\mathbf{n . 3}$ & 2,393 & 52.5 & 4,145 & 94.0 & 4,556 & 162.6 & 4,584 & 2175 & 4,453 & 409.4 \\
\hline
\end{tabular}

Source: Ministry of Industry and Trade.

y Includes seven shareholding companies with a lotal capital of JD 40 milion.

$y$ Includes fourteen shareholding companies with a tow capital of JD 105 milion.

$y$ Includes one shareholding company with a capital of JD 5 million.

4 Includes three shareholding companies with a total capital of JD 25 million. 
Table 25. Jordan: Cost of Living Index, 1989-94

$$
(1992=100)
$$

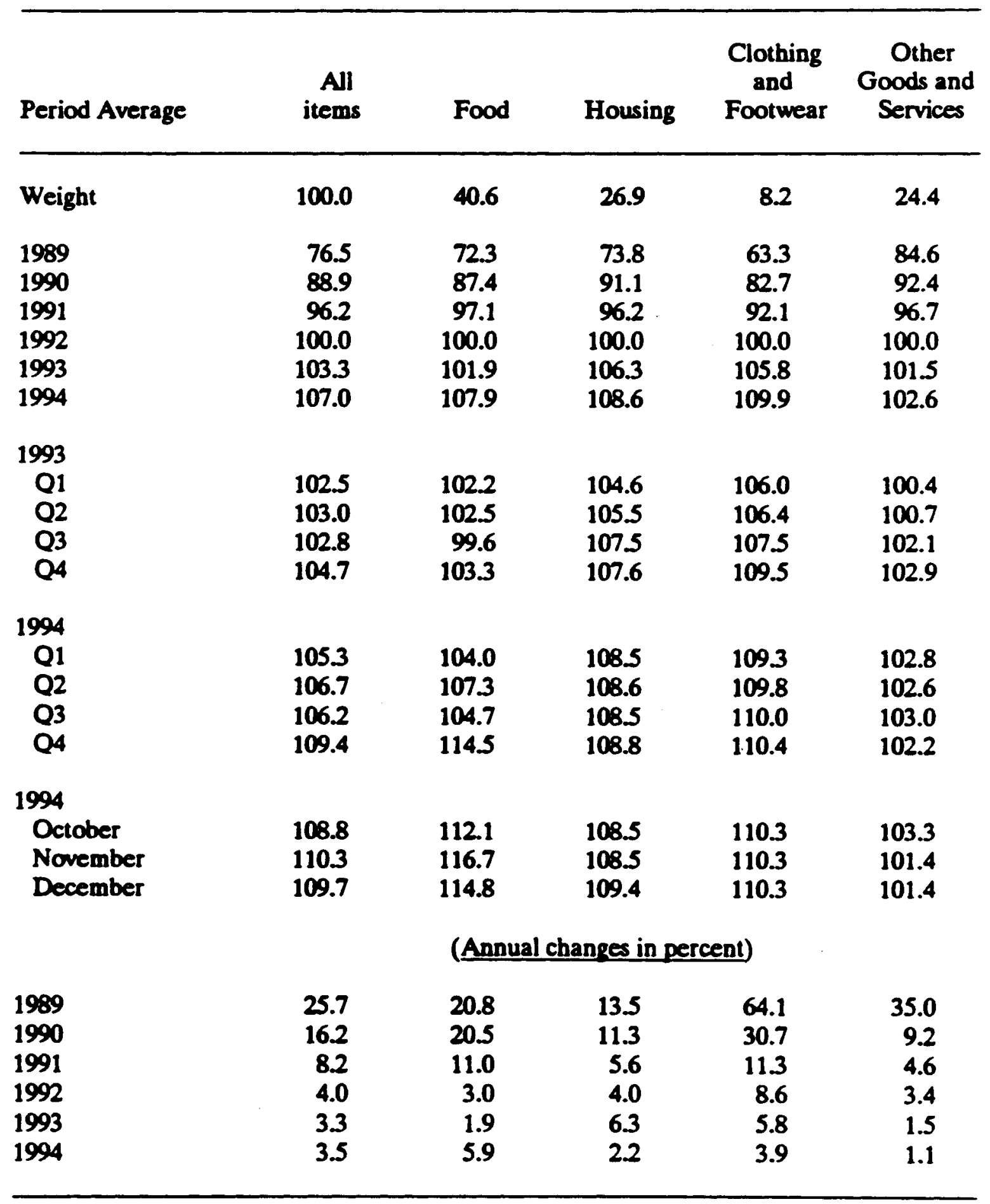

Source: Central Bank of Jordan. 
Table 26. Jordan: Domestic Retail Prices of Petroleum Products, Selected Years

(In fik per unit)

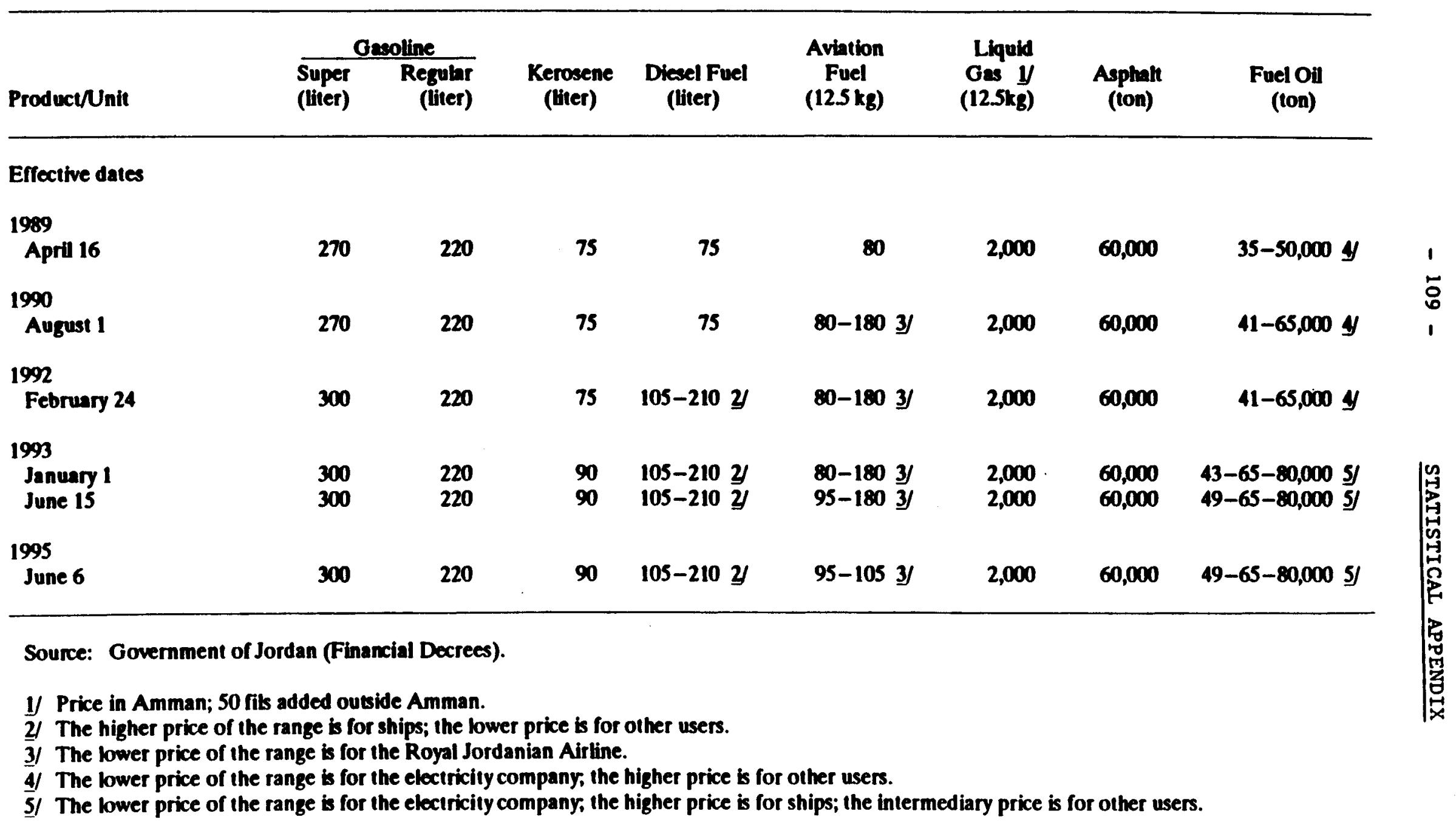


Table 27. Jordan: Government Finances, 1989-94

\begin{tabular}{|c|c|c|c|c|c|c|}
\hline & 1989 & 1900 & 1991 & 1992 & 1993 & $\frac{\text { Prel. }}{1994}$ \\
\hline & \multicolumn{6}{|c|}{ (In millions of Jordan dinar) } \\
\hline $\begin{array}{l}\text { Total reveaue and foreiga grants } \\
\text { Reveave } \\
\text { Tax revenue } \\
\text { Nonter reveaue } \\
\text { Foreiga grabu }\end{array}$ & $\begin{array}{l}869.5 \\
565.2 \\
273.9 \\
291.3 \\
304.3\end{array}$ & $\begin{array}{r}1,026.5 \\
734.8 \\
395.9 \\
338.9 \\
291.7\end{array}$ & $\begin{array}{r}1,052.8 \\
805.2 \\
420.1 \\
385.1 \\
247.6\end{array}$ & $\begin{array}{r}1,306.4 \\
1,169.0 \\
646.0 \\
523.0 \\
137.4\end{array}$ & $\begin{array}{r}1,332.4 \\
1,165.8 \\
643.4 \\
522.4 \\
166.6\end{array}$ & $\begin{array}{r}1,389.8 \\
1.244 .5 \\
694.5 \\
550.0 \\
145.3\end{array}$ \\
\hline $\begin{array}{l}\text { Total expenditure } \\
\text { Current expeaditure } \\
\text { Of which: external intereat y } \\
\text { Capital expenditure } \\
\text { Net lending } \\
\text { Exumbudgetary and ewerveacy expenditure }\end{array}$ & $\begin{array}{r}1,053.8 \\
890.0 \\
180.7 \\
196.4 \\
16.2 \\
-48.8\end{array}$ & $\begin{array}{r}1,220.8 \\
976.2 \\
231.3 \\
159.5 \\
2.2 \\
85.9\end{array}$ & $\begin{array}{r}1,300.6 \\
1,028.1 \\
247.0 \\
167.7 \\
-35.8 \\
140.6\end{array}$ & $\begin{array}{r}1.288 .6 \\
1,100.1 \\
285.5 \\
203.7 \\
-15.2 \\
---\end{array}$ & $\begin{array}{r}1,381.6 \\
1,154.9 \\
220.6 \\
248.7 \\
-22.0 \\
--\end{array}$ & $\begin{array}{r}1.496 .7 \\
1.244 .3 \\
195.4 \\
271.6 \\
-19.2 \\
--\end{array}$ \\
\hline $\begin{array}{l}\text { Overall balance, excluding snats } y \\
\text { Reacheduled iatereat } \\
\text { Overall balance, including grases } y\end{array}$ & $\begin{array}{r}-488.6 \\
48.2 \\
-136.1\end{array}$ & $\begin{array}{r}-489.0 \\
-197.3\end{array}$ & $\begin{array}{r}-495.4 \\
-\overline{-247.8}\end{array}$ & $\begin{array}{r}-119.6 \\
75.0 \\
92.8\end{array}$ & $\begin{array}{r}-215.8 \\
74.5 \\
25.3\end{array}$ & $\begin{array}{r}-252.2 \\
94.1 \\
-12.8\end{array}$ \\
\hline 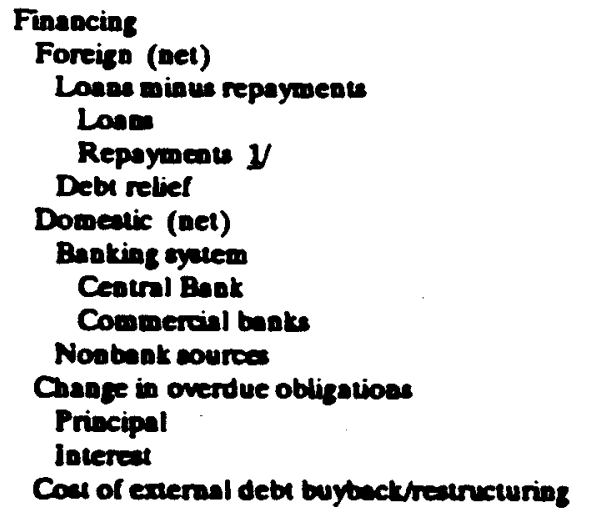 & $\begin{array}{r}136.1 \\
90.6 \\
-119.4 \\
248.4 \\
-367.8 \\
210.0 \\
17.2 \\
21.1 \\
27.2 \\
-6.1 \\
-3.9 \\
28.3 \\
-- \\
28.3 \\
--\end{array}$ & $\begin{array}{r}197.3 \\
210.5 \\
-136.5 \\
249.7 \\
-386.2 \\
347.0 \\
-101.9 \\
-122.5 \\
-139.2 \\
16.7 \\
20.6 \\
88.7 \\
-- \\
88.7 \\
--\end{array}$ & $\begin{array}{r}247.8 \\
24.0 \\
-26.0 \\
386.1 \\
-412.1 \\
50.0 \\
-61.4 \\
-90.7 \\
-74.5 \\
-16.2 \\
29.3 \\
285.2 \\
179.2 \\
106.0 \\
--\end{array}$ & $\begin{array}{r}-92.8 \\
39.2 \\
-183.8 \\
215.6 \\
-399.4 \\
223.0 \\
100.8 \\
85.8 \\
\ldots \\
\ldots \\
15.0 \\
-123.9 \\
-. \\
-123.9 \\
-109.0\end{array}$ & $\begin{array}{r}-25.3 \\
152.7 \\
-192.9 \\
111.0 \\
-303.9 \\
345.6 \\
-13.8 \\
-28.8 \\
\ldots \\
\ldots \\
15.0 \\
-20.2 \\
\ldots \\
\ldots \\
-144.0\end{array}$ & $\begin{array}{r}12.8 \\
41.1 \\
-142.9 \\
139.5 \\
-2824 \\
184.0 \\
-3.8 \\
\ldots \\
\ldots \\
\ldots \\
\ldots \\
-. \\
-- \\
-- \\
-24.5\end{array}$ \\
\hline & \multicolumn{6}{|c|}{ (In percent of GDP) } \\
\hline 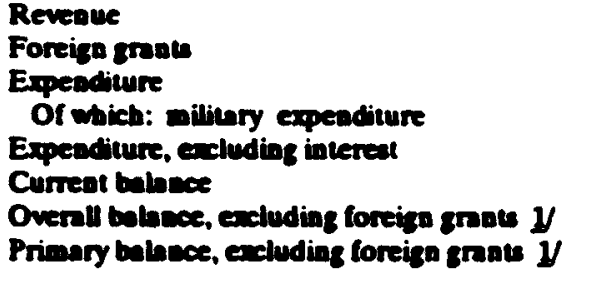 & $\begin{array}{r}23.8 \\
12.8 \\
4.4 \\
10.6 \\
34.9 \\
-13.7 \\
-20.6 \\
-11.1\end{array}$ & $\begin{array}{r}27.5 \\
10.9 \\
45.9 \\
9.6 \\
35.5 \\
-9.0 \\
-18.3 \\
-8.0\end{array}$ & $\begin{array}{r}28.2 \\
8.7 \\
45.6 \\
9.4 \\
35.0 \\
-7.8 \\
-17.4 \\
-6.8\end{array}$ & $\begin{array}{r}33.5 \\
3.9 \\
36.9 \\
8.4 \\
27.8 \\
2.0 \\
-3.4 \\
5.7\end{array}$ & $\begin{array}{r}30.0 \\
4.3 \\
35.6 \\
8.3 \\
29.1 \\
0.3 \\
-5.6 \\
0.9\end{array}$ & $\begin{array}{r}29.2 \\
3.4 \\
35.1 \\
8.5 \\
29.6 \\
0.0 \\
-5.9 \\
-0.4\end{array}$ \\
\hline & \multicolumn{6}{|c|}{ (In millions of Jonden dinars) } \\
\hline PM: GDP at martet prices & 2.3721 & 2668.3 & 2855.1 & 3.493 .0 & 3,8825 & 4.266 .2 \\
\hline
\end{tabular}

Source: Minintry of Finance; and steff catimates.

y Commitment bain.

2 Cach basid. 
Table 28. Jordan: Government Revenue, 1989-94

(In millions of Jordan dinars)

\begin{tabular}{|c|c|c|c|c|c|c|}
\hline & 1989 & 1990 & 1991 & 1992 & 1993 & $\frac{\text { Prel. }}{1994}$ \\
\hline Total revenue & 565.2 & 734.8 & 805.2 & 1.169 .0 & 1.165 .8 & 1.244 .5 \\
\hline Tax revenue & 273.9 & 395.9 & 420.1 & 646.0 & 643.4 & 694.5 \\
\hline Taxes on income and profits & 51.4 & 114.1 & 92.8 & 109.5 & 118.8 & 136.6 \\
\hline Corporations & 283 & 88.4 & 642 & 72.7 & 72.0 & 81.4 \\
\hline Individuals & 14.9 & 16.1 & 18.4 & 24.5 & 30.7 & 35.1 \\
\hline Saleried employee: & 8.2 & 9.6 & 10.2 & 12.3 & 16.1 & 20.1 \\
\hline Taxea on domeatic transaction: & 103.7 & 120.3 & 130.1 & 181.7 & 224.2 & 273.8 \\
\hline Excise dutica/comumption tax/GST & 77.5 & 90.4 & 96.1 & 138.4 & 174.3 & 222.0 \\
\hline Other taxes & 26.2 & 29.9 & 34.0 & 43.3 & 49.9 & 51.8 \\
\hline Taxes on foreign trade & 103.9 & 116.7 & 136.2 & 286.4 & 237.7 & 222.8 \\
\hline Custome duties & 100.4 & 112.3 & 125.2 & 212.9 & 229.7 & 216.8 \\
\hline Duties on returaees' cart & -- & -- & 5.1 & 65.0 & -- & -- \\
\hline Fines end forteits & 3.5 & 4.4 & 5.9 & 8.5 & 8.0 & 6.0 \\
\hline Additional tax & 14.9 & 32.8 & 42.4 & 61.7 & 62.7 & 613 \\
\hline Imports & 9.5 & 213 & 29.7 & 432 & 47.3 & 46.4 \\
\hline Otber & 5.4 & 11.5 & 12.7 & 18.5 & 15.4 & 14.9 \\
\hline Tax on Jordenians working abroad & -- & 12.0 & 18.6 & 6.7 & -- & -- \\
\hline Nontax revenue & 2913 & 338.9 & 385.1 & 523.0 & 522.4 & 550.0 \\
\hline Licenes & 32.3 & 36.3 & 45.7 & 70.5 & 62.0 & 63.4 \\
\hline Fees & 61.9 & 71.7 & 833 & 104.9 & 113.3 & 125.5 \\
\hline Reveaue from post and telephone & 62.7 & 80.6 & 89.1 & 120.3 & 135.9 & 163.9 \\
\hline Intereal and profus & 4.5 & 59.8 & 69.0 & 67.2 & 64.5 & 43.0 \\
\hline laterest & 15.6 & 20.0 & 19.5 & 17.8 & 21.1 & 16.0 \\
\hline Profius & 28.9 & 39.8 & 49.5 & 49.4 & 43.4 & 27.0 \\
\hline Miscellaneous & 89.9 & 90.5 & 98.0 & 160.1 & 146.7 & 154.2 \\
\hline
\end{tabular}

Source: Miniatry of Finasce and Customs. 
Table 29. Jordan: Government Expenditure, 1969-94

(In millions of Jordan dinars)

\begin{tabular}{|c|c|c|c|c|c|c|}
\hline & 1989 & 1990 & 1991 & 1992 & 1993 & $\frac{\text { Prel. }}{1994}$ \\
\hline $\begin{array}{l}\text { Total expeaditure } \\
\text { Current expenditure } \\
\text { Wages and salaries } \\
\text { Purcbases of goods and services } \\
\text { Interest payments } \\
\text { Internal } \\
\text { Enternal } \\
\text { Subsidies } \\
\text { Food } \\
\text { Fuel } \\
\text { Other } \\
\text { Other transfers } \\
\text { Pensions } \\
\text { Social security } \\
\text { Decentralized agencies } \\
\text { Relief operations } \\
\text { Otber } \\
\text { Military expenditure } \\
\text { Capital expenditure } \\
\text { Net lending } \\
\text { Gross lending } \\
\text { Repayments } \\
\text { Eurabudgetary expenditure }\end{array}$ & $\begin{array}{r}1,053.8 \\
890.0 \\
153.7 \\
47.6 \\
226.2 \\
45.5 \\
180.7 \\
74.7 \\
73.1 \\
-- \\
1.6 \\
121.6 \\
74.9 \\
4.1 \\
40.6 \\
2.0 \\
13.8 \\
2524 \\
196.4 \\
16.2 \\
44.7 \\
-28.5 \\
-48.8\end{array}$ & $\begin{array}{r}1223.8 \\
976.2 \\
163.6 \\
42.4 \\
276.0 \\
44.7 \\
231.3 \\
88.1 \\
83.5 \\
4.0 \\
0.6 \\
133.1 \\
83.0 \\
3.9 \\
44.1 \\
2.1 \\
16.7 \\
256.3 \\
159.5 \\
22 \\
31.8 \\
-29.6 \\
85.9\end{array}$ & $\begin{array}{r}1,300.6 \\
1,008.1 \\
186.2 \\
61.1 \\
300.8 \\
53.8 \\
247.0 \\
61.2 \\
61.2 \\
-- \\
-- \\
130.4 \\
87.7 \\
3.9 \\
29.8 \\
9.0 \\
18.7 \\
269.7 \\
167.7 \\
-35.8 \\
22 . \\
-58.0 \\
140.6\end{array}$ & $\begin{array}{r}1,288.6 \\
1,100.1 \\
210.0 \\
70.3 \\
317.9 \\
32.4 \\
285.5 \\
57.3 \\
57.3 \\
-- \\
-- \\
139.6 \\
107.5 \\
4.4 \\
24.3 \\
3.4 \\
15.6 \\
289.5 \\
203.7 \\
-15 . \\
37.2 \\
-52.4 \\
--\end{array}$ & $\begin{array}{r}1,381.8 \\
1,154.9 \\
247.0 \\
73.7 \\
251.0 \\
30.4 \\
220.6 \\
53.6 \\
53.6 \\
-- \\
-- \\
190.6 \\
140.4 \\
4.3 \\
362 \\
9.7 \\
18.0 \\
321.0 \\
248.7 \\
-220 \\
29.5 \\
-51.5 \\
--\end{array}$ & $\begin{array}{r}1,496.7 \\
1,244.3 \\
295.7 \\
83.5 \\
234.5 \\
39.1 \\
195.4 \\
43.2 \\
43.2 \\
-- \\
-- \\
205.1 \\
147.5 \\
5.0 \\
45.0 \\
7.6 \\
21.3 \\
361.0 \\
271.6 \\
-19.2 \\
36.2 \\
-55.4 \\
--\end{array}$ \\
\hline
\end{tabular}

Source: Ministry of Finance and Customs.

y Excludes producer subsidies for domestic production of wheat and barley (about 0.3 percent of GDP) which are incorporated as part of capital expenditure under the authorities' budget. 
Table 30. Jordan: Central Governmeat Budget--Capital Expenditure and Net Lending by Function, 1989-94

\begin{tabular}{|c|c|c|c|c|c|c|}
\hline & 1989 & 1990 & 1991 & 1992 & 1993 & $\frac{\text { Prel. }}{1994}$ \\
\hline & \multicolumn{6}{|c|}{ (In millions of Jordan dinars) } \\
\hline $\begin{array}{l}\text { Total capital expenditure } \\
\text { and net lending }\end{array}$ & 212.6 & 161.4 & 131.9 & 188.5 & 231.8 & 252.4 \\
\hline General public services & 48.3 & 21.9 & 5.1 & 35.1 & 63.6 & 62.3 \\
\hline Social services & 17.8 & 10.4 & 7.6 & 24.4 & 29.9 & 23.8 \\
\hline \multirow[t]{2}{*}{ Economic services } & 146.5 & 129.1 & 119.2 & 129.0 & 138.3 & 166.3 \\
\hline & \multicolumn{6}{|c|}{ (In percent of total capital expenditure and net lending) } \\
\hline General public services & 22.7 & 13.6 & 3.9 & 18.7 & 27.4 & 24.7 \\
\hline Social services & 8.4 & 6.4 & 5.8 & 12.9 & 12.9 & 9.4 \\
\hline Economic services & 68.9 & 80.0 & 90.3 & 68.4 & 59.7 & 65.9 \\
\hline
\end{tabular}

Source: Ministry of Finance and Customs. 
Table 31. Jordan: Import of Crude Oil and Oil Products by Sources, 1991-94

(Quantity in thousands of tons; value in millions of U.S. dollars)

\begin{tabular}{|c|c|c|c|c|c|c|c|c|}
\hline & \multicolumn{2}{|c|}{1991} & \multicolumn{2}{|c|}{1992} & \multicolumn{2}{|c|}{1993} & \multicolumn{2}{|c|}{$\begin{array}{c}\begin{array}{c}\text { Preliminary Actuals } \\
1994 \\
\end{array} \\
\end{array}$} \\
\hline & Quantity & Value & Quantity & Value & Quantity & Value & Quantity & Value \\
\hline \multicolumn{9}{|l|}{ Iraq } \\
\hline Crude oil & $1,880.4$ & 229.1 & $2,996.0$ & 374.6 & $2,930.0$ & 364.0 & $2,980.0$ & 322.0 \\
\hline Fuel oil & 547.2 & 43.6 & 737.0 & 69.7 & 750.0 & 53.0 & 757.0 & 65.0 \\
\hline Gas oil & -- & -- & 140.0 & 25.1 & 100.0 & 16.0 & 102.0 & 14.0 \\
\hline LPG & 1.3 & 0.3 & 32.0 & 7.0 & $\mathbf{4 0 . 0}$ & 8.0 & 52.0 & 9.0 \\
\hline Kerosene & -- & -- & 10.0 & 1.7 & 14.0 & 3.0 & -- & -- \\
\hline Oman & 80.0 & 11.3 & -- & -- & -- & -- & - & -- \\
\hline Syria & 360.3 & 53.2 & -- & -- & -- & -- & -- & -- \\
\hline Yemen & 168.1 & 28.3 & -- & -- & -- & -- & -- & -- \\
\hline Other & 20.5 & 8.5 & -- & -- & -- & -- & -- & -- \\
\hline Pipeline fees & $\ldots$ & 12.0 & -- & -- & -- & 12.0 & -- & 12.0 \\
\hline Total imports & $3,057.8$ & 386.3 & $3,915.0$ & 478.1 & $3,834.0$ & 456.0 & $3,891.0$ & 422.0 \\
\hline
\end{tabular}

Sources: Ministry of Energy; and Ministry of Finance and Customs. 
Table 32. Jordan: Food Subeidies, 1989-94 1/

(In millions of Jordan dinars)

\begin{tabular}{|c|c|c|c|c|c|c|}
\hline Item & 1989 & 1990 & 1991 & 1992 & 1993 & $\frac{\text { Prel. }}{1994}$ \\
\hline Wheat & -362 & -42.4 & -34.7 & -38.8 & -43.3 & -39.5 \\
\hline Barley & -7.2 & -9.4 & -7.0 & -8.3 & -9.0 & -3.3 \\
\hline Rice & -7.3 & -8.3 & -5.2 & -5.3 & -6.7 & -4.8 \\
\hline Sugar & -156 & -18.6 & -2.4 & 1.8 & 2.7 & -0.5 \\
\hline Meat & -5.6 & -1.4 & -- & -- & -- & -- \\
\hline Other & -1.2 & -12.4 & -11.9 & 2.6 & 2.7 & 4.9 \\
\hline $\begin{array}{c}\text { Surplus }(+) \text { or } \\
\text { subsidy }(-)\end{array}$ & -73.1 & -925 & -612 & -48.0 & -53.6 & -432 \\
\hline $\begin{array}{l}\text { Memorandum item: } \\
\text { Total food subsidies } \\
\text { (As percent of GDP) }\end{array}$ & 3.1 & 3.5 & 2.2 & 1.5 & 1.4 & 1.0 \\
\hline
\end{tabular}

Source: Miniary of Supply.

y Negative sign indicates subsidy. 
Table 33. Jordan: Food Subnidies, 1994

\begin{tabular}{|c|c|c|c|c|c|c|}
\hline & $\begin{array}{l}\text { Consumption } \\
\text { (in thomened units) } \\
\text { Ounatity }\end{array}$ & $\begin{array}{l}\text { Perchne } \\
\text { Cost } \\
\text { JDNnit }\end{array}$ & $\begin{array}{l}\text { Additional } \\
\text { Cont } \\
\text { JD/Unit }\end{array}$ & $\begin{array}{l}\text { Cont to } \\
\text { Retnilex } \\
\text { JD/Unit }\end{array}$ & $\begin{array}{l}\text { Selling } \\
\text { Price } \\
\text { JD/Unit }\end{array}$ & $\begin{array}{l}\text { Total } \\
\text { Subuid. } \\
\text { Maluri }\end{array}$ \\
\hline $\begin{array}{l}\text { Whest (MT) } \\
\text { Imported } \\
\text { Domextic (A) } \\
\text { Domentic (B) }\end{array}$ & $\begin{array}{r}593.0 \\
18.0 \\
18.0\end{array}$ & $\begin{array}{r}93.8 \\
145.0 \\
145.0\end{array}$ & $\begin{array}{r}12.4 \\
1.0 \\
1.0\end{array}$ & $\begin{array}{l}1062 \\
146.0 \\
146.0\end{array}$ & $\begin{array}{r}45.07 \\
45.07 \\
66.8\end{array}$ & $\begin{array}{r}-36.25 \\
-1.82 \\
-1.43\end{array}$ \\
\hline $\begin{array}{l}\text { Barley (loo) } \\
\text { Inported } \\
\text { Doneatic }\end{array}$ & $\begin{array}{r}584.0 \\
11.0\end{array}$ & $\begin{array}{r}63.0 \\
105.0\end{array}$ & $\begin{array}{r}12.0 \\
1.0\end{array}$ & $\begin{array}{r}75.0 \\
106.0\end{array}$ & $\begin{array}{l}70.0 \\
70.0\end{array}$ & $\begin{array}{l}-2.92 \\
-0.40\end{array}$ \\
\hline $\begin{array}{l}\text { Sugar (loo) } \\
\text { Subaidined } \\
\text { Martea price }\end{array}$ & $\begin{array}{l}75.0 \\
94.0\end{array}$ & $\begin{array}{l}235.0 \\
235.0\end{array}$ & $\begin{array}{l}145 \\
145\end{array}$ & $\begin{array}{l}249.5 \\
2495\end{array}$ & $\begin{array}{l}130.0 \\
340.0\end{array}$ & $\begin{array}{r}-8.96 \\
8.51\end{array}$ \\
\hline $\begin{array}{l}\text { Rice (100) } \\
\text { Subaidized } \\
\text { Marta price (A) } \\
\text { Marta price (B) }\end{array}$ & $\begin{array}{r}66.0 \\
11.0 \\
5.4\end{array}$ & $\begin{array}{l}225.0 \\
225.0 \\
260.0\end{array}$ & $\begin{array}{l}145 \\
145 \\
14.5\end{array}$ & $\begin{array}{l}239.5 \\
239.5 \\
274.5\end{array}$ & $\begin{array}{l}150.0 \\
300.0 \\
360.0\end{array}$ & $\begin{array}{r}-5.91 \\
0.67 \\
0.46\end{array}$ \\
\hline $\begin{array}{l}\text { Milk (cart) } \\
\text { Subidized }\end{array}$ & 718.0 & 16.5 & 0.42 & 16.92 & 12.72 & -3.06 \\
\hline $\begin{array}{l}\text { Net eurplus from other } \\
\text { commodities and operntions }\end{array}$ & -- & -- & -- & -- & -- & 7.9 \\
\hline Total & & & & & & -43.16 \\
\hline
\end{tabular}

Source: Miviatry of Fiance and Conloms (preliaisary figura) 
Table 34. Jordan: Central Government Domestic Bank Financing by Sources, $1989-94$ y

(In millions of Jorden dinars)

\begin{tabular}{|c|c|c|c|c|c|c|}
\hline & 1989 & 1990 & 1991 & 1992 & 1993 & $\begin{array}{c}\text { Prel. } \\
\text { Actuals } \\
1994\end{array}$ \\
\hline \multicolumn{7}{|l|}{ Central Bank } \\
\hline Treasury bills & -34.5 & -32.8 & -18.5 & -- & 41.9 & 82.0 \\
\hline Government bonds and notes & $\begin{array}{r}1.3 \\
730\end{array}$ & $\begin{array}{r}0.7 \\
267\end{array}$ & -46.7 & $\begin{array}{r}389.6 \\
-300 ?\end{array}$ & $\begin{array}{r}0.5 \\
500\end{array}$ & 5.9 \\
\hline 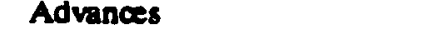 & & & 21 & -3992 & & -- \\
\hline Total borrowing & 39.8 & 4.6 & -63.1 & -9.6 & 102.3 & 87.9 \\
\hline Increase in deposits (-) & -12.6 & 8.8 & 191.1 & 652 & 49.1 & -134.4 \\
\hline Net financing & 272 & 13.4 & -2542 & 55.6 & 151.4 & -46.5 \\
\hline \multicolumn{7}{|l|}{ Commercial banks } \\
\hline Treasury bills & 242 & 26.9 & 373 & -0.4 & -62.7 & -47.6 \\
\hline $\begin{array}{l}\text { Government bonds } \\
\text { Loans and advances }\end{array}$ & 16.2 & -25 & -9.9 & -20.1 & 27.1 & -41.5 \\
\hline Loans and advances & -- & - & -- & -- & -- & 37.6 \\
\hline Tolal borrowing & 40.4 & 24.4 & 27.4 & -20.5 & -35.6 & -51.5 \\
\hline Increace in deposits (-) & -46.4 & -7.7 & -43.6 & -46.1 & -212 & -1.1 \\
\hline Net financing & -6.0 & 16.7 & -162 & -66.6 & -56.8 & -52.6 \\
\hline
\end{tabular}

Source: Central Bank of Jordan.

1) The flows reported in this table may not correspond to the domestic bank finaneing of the Central Government referred to in Table 11, in particular for commercial bank accounts, because of reclassification in the monetary survey in most of the years. 
Table 35. Jordan: Outstanding Public Sector Domestic Debt, 1989-94 y/

(In millions of Jordan dinars)

\begin{tabular}{|c|c|c|c|c|c|c|}
\hline End of Period & 1989 & 1990 & 1991 & 1992 & 1993 & $\begin{array}{c}\text { Prel. } \\
\text { Actuals } \\
1994\end{array}$ \\
\hline Central Government & 976.7 & $1,019.2$ & $1,021.4$ & $1,004.2$ & $1,106.5$ & $1,144.0$ \\
\hline Treasury bills & 224.0 & 217.1 & 2420 & 256.0 & 251.0 & 251.0 \\
\hline Banking system & 223.0 & 216.6 & 238.0 & 236.0 & 251.0 & 251.0 \\
\hline Central Bank of Jordan & 52.0 & 18.8 & - & - & 423 & 126.5 \\
\hline Commercial banks & 171.0 & 197.8 & 238.0 & 236.0 & 208.7 & 124.5 \\
\hline Other bolders & 1.0 & 0.5 & 4.0 & 20.0 & - & - \\
\hline Government bonds and notes & 134.5 & 134.5 & 156.5 & 540.5 & 540.5 & 540.5 \\
\hline Banking system & 90.1 & 67.9 & 64.1 & 449.3 & 450.2 & 448.9 \\
\hline Central Bank of Jordan & 32.9 & 13.1 & 0.6 & 390.2 & 390.7 & 396.5 \\
\hline Commercial banks & 57.2 & 54.8 & 63.5 & 59.1 & 59.5 & 52.4 \\
\hline Other bolders & 44.4 & 66.6 & 924 & 91.2 & 90.3 & 91.6 \\
\hline Treasury bonds & 820 & 95.0 & 48.0 & 320 & 320 & 320 \\
\hline Banking system & 80.9 & 95.0 & 48.0 & 31.0 & 31.1 & 31.1 \\
\hline Central Bank of Jordan & 5.6 & 17.4 & -- & -- & -- & - \\
\hline Commercial banks & 75.3 & 77.6 & 48.0 & 31.0 & 31.1 & 31.1 \\
\hline Other holders & 1.1 & -- & -- & 1.0 & 0.9 & 0.9 \\
\hline Central Bank advances & 536.2 & 5726 & 574.9 & 175.7. & 235.6 & 235.6 \\
\hline Commercial banks advances & -- & -- & -- & -- & 47.4 & 84.9 \\
\hline Public corporation bonds & 18.3 & 18.3 & 40.3 & 37.3 & 37.3 & 37.3 \\
\hline Banking syctem & 8.7 & 7.9 & 21.6 & 18.6 & 18.7 & 17.9 \\
\hline Central Bank of Jordan & 0.4 & 0.3 & 0.2 & - & 0.1 & 0.1 \\
\hline Commercial banks & 8.3 & 7.6 & 21.4 & 18.6 & 18.6 & 17.8 \\
\hline Otber bolders & 9.6 & 10.4 & 18.7 & 18.7 & 18.6 & 19.4 \\
\hline Total domestic debt & 995.0 & $1,037.5$ & $1,061.7$ & $1,041.5$ & $1,143.8$ & $1,181.3$ \\
\hline
\end{tabular}

Source: Central Bank of Jordan.

1/ Covers central government as well as public corporations. 
Table 36. Jordan: Factors Afecting Changen in Money Supply, 1989-94

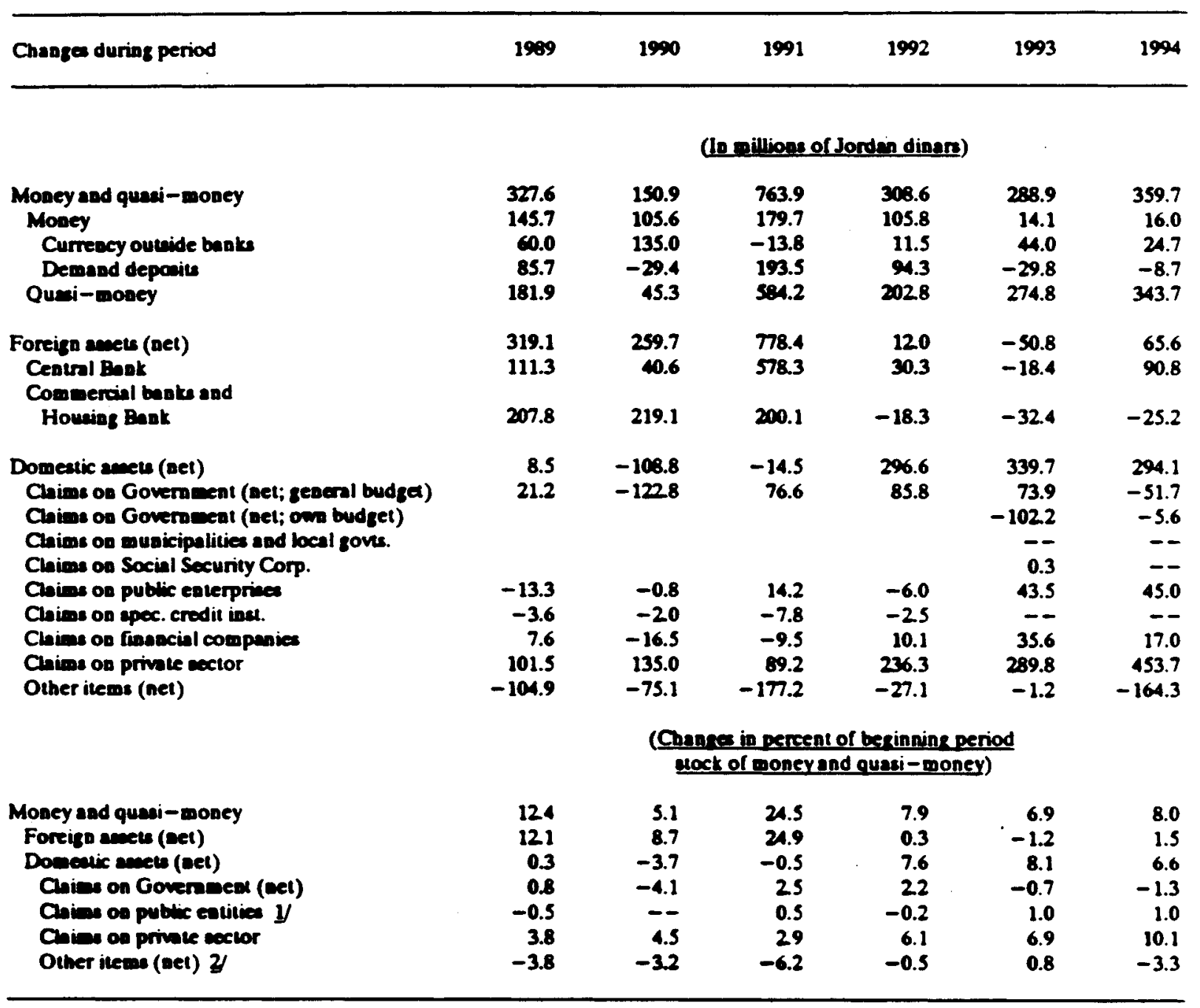

Somves: Ceatrel Batk of Jordan.

1/ Ano includes claims on musicipalities and beal governments and claims on the Social Security Corporation.

2) Abo includes claims on finsecial institutions. 
Table 37. Jordan: Monetary Survey, 1989-94

(In millions of Jordan dinare)

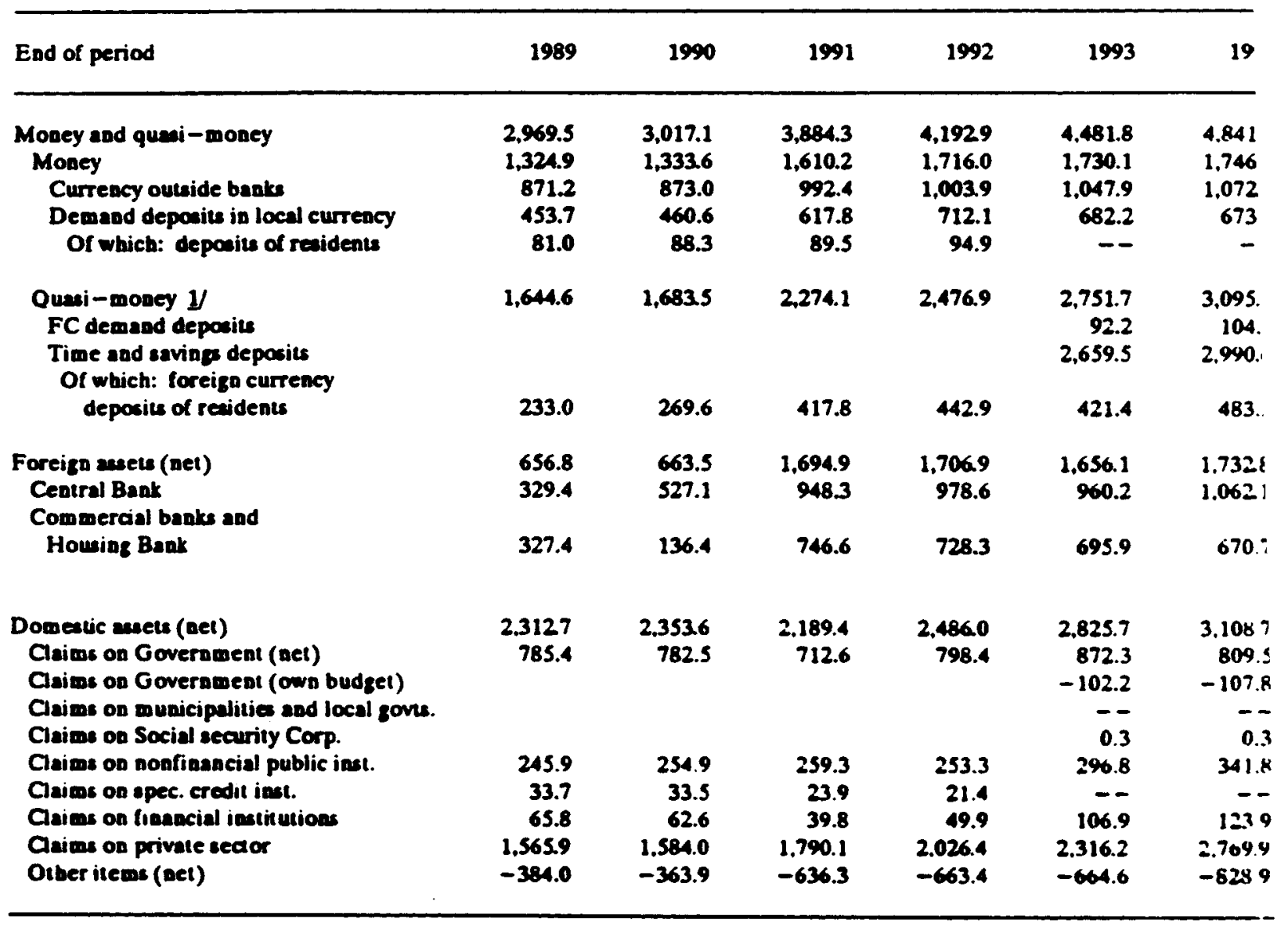

Source: Ceatral Bank of Jordan and staff eatimates.

1/ Deposits of: private sector (resident), public noafinancial institutions, muncipalities and local governements, finencial institution and Social Security Corporation. 
Table 38. Jordan: Balance Steet of the Contral Bank, 1989-94

(le pillioge of Jorden dinere)

\begin{tabular}{|c|c|c|c|c|c|c|}
\hline Ead of period & 1909 & 1990 & 1991 & 1992 & 1993 & 1994 \\
\hline Foreign anests & 330.2 & 565.4 & 949.1 & $1,001.1$ & 955.1 & 1.085 .9 \\
\hline Claims os Government (geacral budget) & 664.4 & 621.8 & 605.9 & 596.3 & 698.8 & 786.8 \\
\hline Of which: T-bilh & & & & & 41.9 & 123.9 \\
\hline Advasces lo Government & & & & & 235.6 & 235.6 \\
\hline Claibs os Ceatral Governmeat (own budget) & & & & & 0.1 & -- \\
\hline Claims on public entitioe & 0.4 & 0.5 & 0.2 & 0.0 & & \\
\hline Claims on social security corporation & & & & & -- & -- \\
\hline Claims on apecialized crodit institutions & 33.7 & 33.5 & 23.9 & 21.4 & -- & -- \\
\hline $\begin{array}{l}\text { Claims os deponit enosey bank } \\
\text { Of whicb: redincounat fecilities }\end{array}$ & 219.0 & 245 & 3945 & 365.9 & $\begin{array}{r}348.1 \\
55.2\end{array}$ & $\begin{array}{r}367.6 \\
85.1\end{array}$ \\
\hline Bail-oul operations & & & & & 2929 & 282.5 \\
\hline Chimes on freascial institution $\mathbf{y}$ & 33.2 & 29.1 & 21 & 1.1 & 25.7 & 29.7 \\
\hline Claiens on pubtic nosfiasncial companie & & & & & -- & 0.1 \\
\hline Chiest on privale sector & 3.4 & 3.2 & 3.7 & 4.4 & 5.7 & 6.5 \\
\hline Usclaneified amets & 73.3 & 71.1 & 39.7 & 22.6 & 222 & 18.7 \\
\hline Anets & $1,357.6$ & 1.569 .1 & 2019.1 & 2,0128 & 2.055 .7 & 2.295 .3 \\
\hline Lisbilitien & 1.357 .6 & 1.569 .1 & 2019.1 & 20128 & 2055.7 & 2.295 .3 \\
\hline Curreacy & 287.5 & 8893 & $1,017.6$ & 1.0324 & $1,077.8$ & 1.112 .8 \\
\hline Baokers' deponits & 2126 & $\$ 14.6$ & 634.1 & 7125 & 776.6 & 775.5 \\
\hline Or which: CDr in JD & & 220.4 & & & 120.3 & 280.1 \\
\hline Legal newerve & & & & & 387.9 & 430.4 \\
\hline Encoue reservas & & & & & 120.6 & 75.0 \\
\hline Remuseraled deponits & & & & & 147.8 & -- \\
\hline Dewand deponils & & & & & 0.2 & 75 \\
\hline Public gonfrasocial institution $\mathbf{y}$ & 6.6 & S.o & 13.8 & 15.7 & 4.6 & 6.2 \\
\hline Or which: FCD & 1.0 & 0.8 & 0.8 & 0.8 & 3.1 & 4.4 \\
\hline Municipalotion and beal governments & & & & & 0.1 & 0.1 \\
\hline Or which: FCD & & & & & 0.1 & -- \\
\hline Fiessciel ineditutions & & & & & 0.9 & 1.1 \\
\hline Of which: FCD & & & & & -- & -- \\
\hline Social necurity corporabion & & & & & 0.6 & 0.1 \\
\hline Or which: FCD & & & & & - & -- \\
\hline Dereand deponits of privale sector & 22.2 & 27.1 & 10.2 & 10.6 & -- & -- \\
\hline Or whict: FCD & 22.0 & 27.1 & 10.2 & 10.6 & -- & $\ldots$ \\
\hline Ousai - nosecary deponits & & & & & 4.0 & 2.1 \\
\hline Public soofinancial iestitution $y$ & 5.1 & 5.1 & 15.7 & 16.4 & 3.7 & 1.8 \\
\hline Or which: FCD & 0.0 & 0.0 & 26 & 153 & 3.7 & 1.8 \\
\hline Municipalition and bocal goverenests & & & & & -- & -- \\
\hline Or which: FCD & & & & & -- & - \\
\hline $\begin{array}{l}\text { Firancial inacitutione } \\
\text { Or which: FCD. }\end{array}$ & & & & & $\overline{--}$ & $=$ \\
\hline $\begin{array}{l}\text { Or which: FCD } \\
\text { Social socurity corporation }\end{array}$ & & & & & $\overline{0.3}$ & 0.3 \\
\hline Or whict: FCD & & & & & -- & -- \\
\hline Privale sector & 1.0 & 26.4 & 21.4 & 11.7 & -- & -- \\
\hline Or which: FCD & 1.0 & 26.4 & 21.4 & 11.7 & -- & -- \\
\hline Foreiga linblition 2 & 0.8 & 38.3 & 0.8 & 22.5 & -5.1 & 34.9 \\
\hline Cenural govern neal depovils (geaeral budget) y & 28.5 & 17.2 & 210.8 & 116.3 & 1023 & 180.5 \\
\hline Central govern weat deponits (own budget) & & & & & 4.4 & 11.5 \\
\hline Capilal socounen & 18.0 & 18.0 & 18.0 & 18.0 & 18.0 & 21.8 \\
\hline Provinio: & 104.0 & 104.0 & 45.6 & 28.8 & 42.3 & 113.6 \\
\hline $\begin{array}{l}\text { Unclemified liabilitio } \\
\text { Of which: Govereneat Trus Acoount }\end{array}$ & 413 & 24.1 & 31.1 & 27.9 & 29.2 & 35.1 \\
\hline
\end{tabular}

Source: Central Bank of Jordas.

1i laciudes specialized credil inatitudions.

2) Adjusted for purchemes and repurchenes from the IMF. 
Table 39. Jordan: Coasolidated Balance Sheet of Commercial Banks and the Housing Bank, 1989-94

(In millions of Jordan dinars)

\begin{tabular}{|c|c|c|c|c|c|c|}
\hline Ead of period & 1989 & 1990 & 1991 & 1992 & 1993 & 1994 \\
\hline Reverves: & 256.5 & 415.3 & 629.3 & 737.4 & 816.2 & 822.7 \\
\hline Currency & 16.3 & 16.3 & 25.2 & 28.5 & 29.9 & $\$ 0.2$ \\
\hline Depoejts with Central Bank & 20.2 & 399.0 & 604.1 & 708.9 & 786.3 & 782.5 \\
\hline Of which: FCD & & 216.3 & & & & \\
\hline Foreign mets & 832.3 & 655.2 & 2007.0 & 2324.8 & 2221.2 & 2436.2 \\
\hline Claims on Government & 311.0 & 333.6 & 362.9 & $\mathbf{4 0 9 . 9}$ & 345.4 & 285.4 \\
\hline Claims on central government (own budget) & & & & & 13.3 & 21.6 \\
\hline Claims on municipalities and bocal government & & & & & -- & - \\
\hline Claims on rocisl recurity corporation & & & & & 0.0 & 0.0 \\
\hline Claims on finascial inctitutions & 32.6 & 33.5 & 37.7 & 48.8 & 81.2 & 94.2 \\
\hline Claims on nonfinancial public enterprises & 245.5 & 254.4 & 259.1 & 253.3 & 296.8 & 34.8 \\
\hline Claims on private sector y & 15625 & 1580.8 & 1786.4 & 20220 & 2310.5 & 2763.4 \\
\hline Unctessifiod amets & 539.9 & 570.4 & 516.7 & 514.9 & 662.9 & 762.5 \\
\hline Anets & 3780.3 & 3843.2 & 5599.1 & 6311.1 & 6747.5 & 7527.8 \\
\hline Liabilities & 3780.3 & $3 \% 43.2$ & 5599.1 & 6311.1 & 6747.5 & 7527.8 \\
\hline Demand depoails & $\$ 24.9$ & 428.5 & 593.8 & 685.8 & 768.2 & 770.8 \\
\hline Public aonfinancial enterprises & 11.7 & 10.5 & 20.6 & 31.8 & 4.7 & 33.2 \\
\hline Of which: FCD & 5.0 & 5.0 & 1.6 & 23 & 2.9 & 8.2 \\
\hline Muaicipalitics and local governments & & & & & 7.7 & 6.2 \\
\hline Of which: FCDs & & & & & -- & - \\
\hline Finencial inetitutions & & & & & 5.7 & 6.4 \\
\hline Of which: FCD & & & & & 0.6 & 2.3 \\
\hline Social security corporation & & & & & 9.6 & 4.4 \\
\hline Of which: FCD: & & & & & -- & - \\
\hline Private sector & 413.2 & 418.0 & 573.2 & 654.0 & 700.5 & 7200 \\
\hline Of whict: FCD & $\mathbf{5 3 . 0}$ & 55.4 & 76.9 & 81.2 & 85.5 & 89.9 \\
\hline Time and suviags deporils & 1638.5 & 16520 & 2237.0 & 2488.8 & 2655.5 & 2988.5 \\
\hline Public nonfinancial enterprises & 724 & 76.2 & 253.3 & 331.1 & 33.1 & 58.2 \\
\hline Of which: FCD & 20 & 1.6 & 10.9 & 8.1 & 4.0 & 10.9 \\
\hline Municipalstie and local goversments & & & & & 25.7 & 11.6 \\
\hline Of which: FCD. & & & & & -- & -- \\
\hline Financial institutions & & & & & 35.2 & 32.6 \\
\hline Or which: FCD & & & & & 1.8 & 3.4 \\
\hline Social security corporation & & & & & 234.4 & 308.5 \\
\hline Of which: FCD & & & & & -- & -- \\
\hline Privale sector & 1566.1 & 1575.8 & 1983.7 & 2117.7 & 2327.1 & 2579.6 \\
\hline Of which: FCD & 230.0 & 241.6 & 3829 & 407.8 & 411.9 & 467.4 \\
\hline Foreign lisbilitiea & $\operatorname{sen} .9$ & 518.8 & 1260.4 & $15 \% .5$ & 1525.3 & 1765.5 \\
\hline Central government depoails & 161.5 & 155.7 & 45.4 & 91.5 & 69.6 & 71.1 \\
\hline Central Goveroment deporits (own budget) & & & & & 111.2 & 117.9 \\
\hline Credit from Central Baak & 213.1 & 233.9 & $\mathbf{4 0 7 . 2}$ & 428.4 & 344.0 & 362.4 \\
\hline Capital scoounts & 281.0 & 209.1 & 348.5 & 346.5 & 492.6 & 582.8 \\
\hline Pronsions & & 78.2 & & & & \\
\hline Unclaesified liabilities & 556.4 & $\mathbf{5 6 7 . 0}$ & 706.8 & 711.6 & 781.1 & 868.8 \\
\hline
\end{tabular}

Source: Central Bank of Jordan.

y Includes credit to mixed (private and public sector) enterprises. 


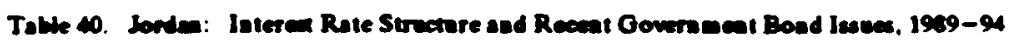

\begin{tabular}{|c|c|c|c|c|c|c|}
\hline Ead of Period & 1939 & $19 \% 0$ & 1991 & 1992 & 1993 & 1994 \\
\hline 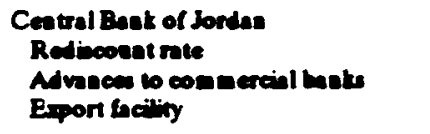 & $\begin{array}{r}8.5 \\
8.5 \\
6.00-8.00\end{array}$ & $\begin{array}{r}8.5 \\
8.5 \\
6.0-8.0\end{array}$ & $\begin{array}{r}8.5 \\
8.5 \\
6.0-8.0\end{array}$ & $\begin{array}{l}8.5 \\
8.5 \\
5.0\end{array}$ & $\begin{array}{l}8.5 \\
8.5 \\
3.5\end{array}$ & $\begin{array}{l}8.5 \\
8.5 \\
6.0\end{array}$ \\
\hline 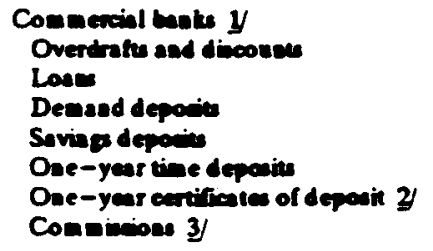 & $\begin{array}{r}10.0 \\
10.0 \\
4.0 \\
6.2 \\
9.2 \\
7.375-9.0 \\
27\end{array}$ & $\begin{array}{r}10.0-12.5 \\
10.0-125 \\
0-5.0 \\
4.0-8.0 \\
6.75-9.5 \\
7.375-9.0 \\
1.0\end{array}$ & $\begin{array}{r}10.0-13.0 \\
10.0-13.0 \\
0-6.0 \\
55-7.0 \\
7.0-9.5 \\
7375-9.0 \\
1.0\end{array}$ & $\begin{array}{r}10.0-14.0 \\
10.0-14.0 \\
0-6.0 \\
3.0-7.0 \\
5.5-8.75 \\
\because \% \\
1.0\end{array}$ & $\begin{array}{r}10.0-13.0 \\
10.0-14.0 \\
0-5.0 \\
3.0-8.0 \\
5.0-8.25 \\
7.5 \\
1.0\end{array}$ & $\begin{array}{r}9.0-14.0 \\
9.0-15.0 \\
0-5.0 \\
3.0-7.5 \\
5.0-8.75 \\
7.66 \\
0.25-1.0\end{array}$ \\
\hline 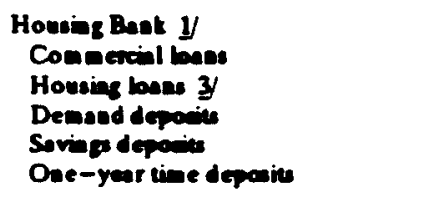 & $\begin{array}{r}10.0 \\
10.0 \\
4.0 \\
5.0 \\
8.75\end{array}$ & $\begin{array}{r}11.0-12.0 \\
10.0 \\
-\overline{5.0} \\
7.25-8.50\end{array}$ & $\begin{array}{r}11.0-12.0 \\
10.0 \\
-- \\
5.0 \\
6.75-8.0\end{array}$ & $\begin{array}{l}\cdots \\
\cdots \\
\cdots \\
\cdots\end{array}$ & $\begin{array}{r}11.25-125 \\
10.0 \\
-\overline{5.0} \\
6.0-7.0\end{array}$ & $\begin{array}{r}11.5-125 \\
10.0 \\
-- \\
5 \\
6.5-7.5\end{array}$ \\
\hline 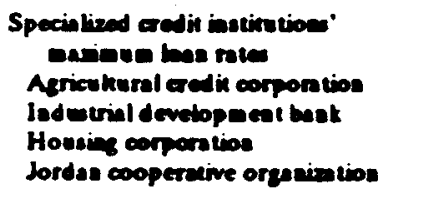 & $\begin{array}{l}10.0 \\
10.0 \\
10.0 \\
10.0\end{array}$ & $\begin{array}{l}10.0 \\
10.0 \\
10.0 \\
10.0\end{array}$ & $\begin{array}{l}10.0 \\
10.0 \\
10.0 \\
10.0\end{array}$ & $\begin{array}{c}\mathbf{1 0 . 0} \\
\cdots \\
\cdots \\
\cdots\end{array}$ & $\begin{array}{r}8.5 \\
11.0 \\
10.0 \\
8.5\end{array}$ & $\begin{array}{r}8.5 \\
11.0 \\
10.0 \\
--\end{array}$ \\
\hline Three- -oontb treasery bills & 6.00 & 6.25 & 5.0 & 3.00 & 3.26 & 8.01 \\
\hline $\begin{array}{l}\text { Menoracduc inee: } \\
\text { Anewal rute of change in the } \\
\text { cout of breg ider }\end{array}$ & 25.8 & 15.4 & 8.9 & 4.0 & 3.3 & 3.6 \\
\hline Goversenesi bode (rocest ineven) & Amowet & & Jetesent $\mathbf{R e}$ & & $\begin{array}{r}\text { Terms of } M \\
\text { in Year }\end{array}$ & \\
\hline $\begin{array}{l}1991 \\
\text { April } \\
\text { Auguat } \\
\text { Noweenter }\end{array}$ & $\begin{array}{r}8.0 \\
10.0 \\
10.0\end{array}$ & & $\begin{array}{l}9.0 \\
9.0 \\
9.0\end{array}$ & & $\begin{array}{l}6.0 \\
9.0 \\
9.0\end{array}$ & \\
\hline $\begin{array}{l}1992 \\
\text { Mared }\end{array}$ & 6.0 & & 9.0 & & 10.0 & \\
\hline $\begin{array}{c}1993 \\
\text { Jely }\end{array}$ & 8.0 & & 9.0 & & 10.0 & \\
\hline $\begin{array}{l}\text { jom } \\
\text { Juse } \\
\text { Nov. }\end{array}$ & $\begin{array}{l}7.5 \\
8.0\end{array}$ & & $\begin{array}{l}8.2 \\
8.5\end{array}$ & & $\begin{array}{l}8.0 \\
7.0\end{array}$ & \\
\hline
\end{tabular}

Source: Cemtal Back of Jordes.

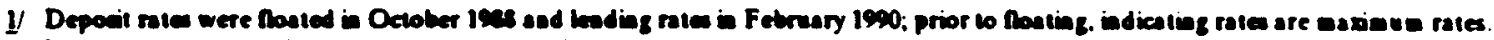

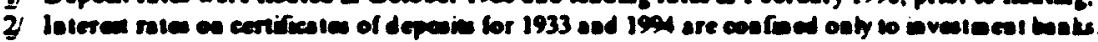

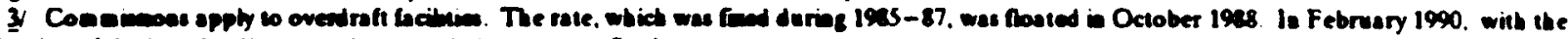
Dosting of the base beadiog rate, the conenienien rate was fbed at one percent.

4 Masionen rale. 
Table 41. Jordan: Commercial Banks' Liquidity and Reacres, 1989-94

\begin{tabular}{|c|c|c|c|c|c|c|}
\hline End of Period & 1989 & 1990 & 1991 & 1992 & 1993 & 1994 \\
\hline Liquid secets $y$ & $1,304.0$ & $1,308.6$ & 28881.4 & 3.172 .3 & $2,673.1$ & 2,6982 \\
\hline $\begin{array}{l}\text { Reaerve amets: } \\
\text { Current deposits with } \\
\text { Ceatrol Bank } y\end{array}$ & 2202 & 1975 & 2933 & 3532 & 481.7 & 448.9 \\
\hline $\begin{array}{l}\text { Liquidity ratio-related } \\
\text { liabilities } 3\end{array}$ & $2,415.7$ & $2,506.0$ & 4253.8 & $4,970.1$ & $4,609.4$ & 5.146 .7 \\
\hline $\begin{array}{l}\text { Reserve ratio-related } \\
\text { liabilities } \downarrow\end{array}$ & $1,909.8$ & $2,013.6$ & $2,643.9$ & $2,962.7$ & $3.505 s$ & $3,884.5$ \\
\hline $\begin{array}{l}\text { Liquidity ratio } \\
\text { Legal } \\
\text { Actual }\end{array}$ & $\begin{array}{l}30.0 \\
54.0\end{array}$ & $\begin{array}{l}30.0 \\
522\end{array}$ & $\begin{array}{l}30.0 \\
67.7\end{array}$ & $\begin{array}{l}30.0 \\
63.8\end{array}$ & $\begin{array}{l}30.0 \\
58.0\end{array}$ & $\begin{array}{l}30.0 \\
52.4\end{array}$ \\
\hline $\begin{array}{l}\text { Reserve ratio (JD deposits) } \\
\text { Legal }\end{array}$ & & & & & & \\
\hline $\begin{array}{l}\text { Demand depocits } \\
\text { Time and esvings deposits } \\
\text { Werghted average } \\
\text { Actual }\end{array}$ & $\begin{array}{l}11.0 \mathrm{~s} / \\
11.0 \mathrm{~s} / \\
11.0 \\
11.5\end{array}$ & $\begin{array}{r}11.0 \\
11.0 \\
11.0 \\
9.8\end{array}$ & $\begin{array}{l}11.0 \\
11.0 \\
11.0 \\
11.1\end{array}$ & $\begin{array}{l}13.0 \\
13.0 \\
13.0 \\
11.9\end{array}$ & $\begin{array}{l}15.06 / \\
15.06 \\
15.0 \\
13.7\end{array}$ & $\begin{array}{l}15.0 \\
15.0 \\
15.0 \\
11.6\end{array}$ \\
\hline 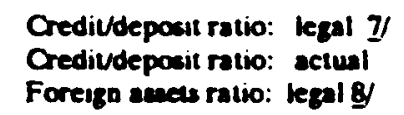 & $\begin{array}{l}70.0 \\
56.4 \\
15.0\end{array}$ & $\begin{array}{l}70.0 \\
61.3 \\
15.0\end{array}$ & $\begin{array}{l}70.0 \\
42.8 \\
15.0\end{array}$ & $\begin{array}{l}70.0 \\
45.3 \\
15.0\end{array}$ & $\begin{array}{r}70.0 \\
44.0 \\
15.0\end{array}$ & $\begin{array}{l}70.0 \\
50.9 \\
15.0\end{array}$ \\
\hline
\end{tabular}

\section{Source: Ceneral Bank of Jordan.}

1/ Includes cash in vull. balances with the Central Bank of Jordan, government boads and bills, convertible belunces with banks abroed (net), and intertank deposits (net).

2) No intereal is paid on reacerve amels.

3. Defined to include demand. time and savings deposits, interbank deposits (net). and other liabilities. The deposits include sovernenent and eemigovernment agency depasits and deposits of residents and nonreaidents denominated in foreign currencies : other liabilitiea unclude bilk. payable borrowings, and deposits of foreign-owned banks with ther branches in Jardan.

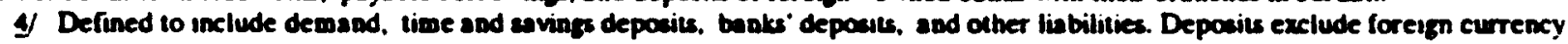
deposits of nonreaidents; and other lisbilities include borrowings and deposits of foreign-owned bants with their branches in Jordan.

5/ Efrective Oclober 16, 1939.

6. Eflective March 1993.

II Defined as the ratio of bilts, diecounced loans, advances and overdrafts (excluding ayndicated loans and bonds of corporations and public entities) to customers' depotits, set interbank deposits, and paid-up capital.

8f Defined as combercial batk belances abrond as a proporion of foreign obligations; the bituer in defined as bukker'ecceplances and documentary credits. The ratio is not applied to the foreign aneu counterpart of the foreign currency depcsits of residents and acareaidents. 
Table 42. Jorden: Consolidated Accounts of the

Specialized Credit Institutions, y 1989-94

(In millions of Jorchn dinars)

\begin{tabular}{|c|c|c|c|c|c|c|c|}
\hline \multirow[b]{2}{*}{ End of Period } & \multirow[b]{2}{*}{1909} & \multicolumn{3}{|c|}{ (Old Clasesification) } & \multicolumn{3}{|c|}{ (New Classification) } \\
\hline & & 1990 & 1991 & 1992 & 1993 & 19932 & $19943 /$ \\
\hline Cash & 0.3 & 0.3 & 0.3 & 0.4 & 0.2 & 0.136 & 0.069 \\
\hline Balances with commercial banks & 41.7 & 38.3 & 624 & 49.6 & 27.1 & 70.026 & 47.358 \\
\hline Balances with Central Bank of Jordan & 0.4 & 0.5 & 3.1 & 0.2 & 1.1 & 0.435 & 0.300 \\
\hline Government bonds and bills & 29 & 3.0 & 3.0 & 24 & 1.8 & $\ldots$ & ... \\
\hline Other liquid assets & -- & -- & -- & -- & -- & -- & $\cdots$ \\
\hline Negotiable ascets & 99.1 & 117.2 & 29.8 & 324 & 36.8 & $\ldots$ & $\ldots$ \\
\hline Loans to private sector & 159.8 & 160.8 & 173.8 & 204.3 & 237.1 & 231.708 & 226.646 \\
\hline Loans to public sector & 50.6 & 49.0 & 46.0 & 44.2 & 46.1 & $\cdots$ & $\cdots$ \\
\hline Balances with other banking institutions & $\ldots$ & $\ldots$ & $\ldots$ & $\ldots$ & $\cdots$ & -- & -- \\
\hline Claims on nonbanking financial institutions & $\cdots$ & $\ldots$ & $\cdots$ & ... & $\cdots$ & -- & 0.175 \\
\hline Claims on other banking institutions & $\ldots$ & $\ldots$ & $\cdots$ & $\cdots$ & $\cdots$ & $-\overline{-}$ & -- \\
\hline $\begin{array}{l}\text { Claims on central goverment } \\
\text { Claims on municipalities and }\end{array}$ & $\ldots$ & $\ldots$ & $\cdots$ & $\cdots$ & $\cdots$ & 0.737 & 3.218 \\
\hline public debt & $\ldots$ & $\ldots$ & $\ldots$ & $\ldots$ & ... & 63.17 & 60.782 \\
\hline Fired ascets & 6.6 & 7.0 & 9.3 & 9.3 & 9.8 & 9.051 & 9.809 \\
\hline Other ascets & 23.4 & 26.8 & 36.3 & 46.1 & 74.6 & 37.008 & 57.772 \\
\hline Ascets $=$ Liabilities & 384.8 & 4029 & 364.0 & 388.9 & 434.6 & 412.273 & 406.127 \\
\hline Deposits & 323 & 35.4 & 59.0 & 48.0 & 31.2 & 68.832 & 45.552 \\
\hline Capital & 56.3 & 57.2 & 4.9 & 66.3 & 68.6 & 52946 & 53.946 \\
\hline Reserves & 24.5 & 29.6 & 33.6 & 35.5 & 40 & 37.924 & 39.191 \\
\hline Credit from Government & 28 & 29 & 3.1 & 1.9 & 1.1 & 17.146 & 16.593 \\
\hline $\begin{array}{l}\text { Credit from Central Bank of Jordan } \\
\text { Credit from foreign }\end{array}$ & 29.5 & 31.1 & 23.3 & 20.1 & 16.5 & 26.168 & 27.733 \\
\hline institutions & 39.8 & SO.0 & 57.8 & 67.0 & 77.2 & 79.035 & 83.767 \\
\hline Credit from banks & 70.2 & 73.6 & 69.3 & 69.6 & 67.7 & 60.200 & 59.200 \\
\hline Other borrowing & $\ldots$ & $\ldots$ & $\ldots$ & $\cdots$ & ... & 13.48 & 13.923 \\
\hline Other liabilities & 129.4 & 123.1 & 73.0 & 80.5 & 132.3 & 55.533 & 66.222 \\
\hline
\end{tabular}

Source: Central Bank of Jordan.

1/ Includes the Agricultural Credit Corporation; the Cities and Villages Development Bank; the Housing Corporation; the Industrial Development Bank; and the Jordan Cooperative Organization.

2/ Effective December 1993, data for specialized credit institution were reclassified to new definitions of monetary sectors.

3. As of November 30, 1994. 
Table 43. Jordan: Outstanding Loans of Specialized Credit Institutions, 1989-941/

(In millions of Jordan dinars)

\begin{tabular}{lcccccr}
\hline End of Period & 1989 & 1990 & 1991 & 1992 & 1993 & $19942 j$ \\
\hline $\begin{array}{l}\text { Agricultural Credit } \\
\text { Corporation }\end{array}$ & 33.9 & 36.6 & 41.7 & 56.6 & 67.7 & 74.0 \\
$\begin{array}{l}\text { Cities and Villages } \\
\text { Development Bank }\end{array}$ & 50.6 & 48.9 & 46.0 & 44.3 & 46.1 & 44.1 \\
$\begin{array}{l}\text { Housing Corporation } \\
\begin{array}{l}\text { Industrial Development } \\
\text { Bank }\end{array}\end{array}$ & 69.1 & 64.8 & 67.1 & 79.5 & 81.5 & 77.0 \\
$\begin{array}{l}\text { Jordan Cooperative } \\
\text { Organization }\end{array}$ & 46.4 & 49.6 & 54.6 & 65.3 & 79.5 & 78.1 \\
$\quad$ Total & 10.5 & 9.8 & 10.4 & 10.5 & 8.4 & 9.6 \\
\hline
\end{tabular}

Source: Central Bank of Jordan.

1) Excluding the Housing Bank.

2) Preliminary. 
Table 44. Jordan: Sectoral Distribution of Outstanding Credit to the Private Sector from Commercial Banks and the Housing Bank. 1989-94

(In millions of Jordan dinars)

\begin{tabular}{|c|c|c|c|c|c|c|c|}
\hline \multirow[b]{2}{*}{ End of Period } & \multicolumn{4}{|c|}{ Old Onssification } & \multicolumn{3}{|c|}{ New Classification } \\
\hline & $\overline{1989}$ & 1990 & 1991 & 1992 & 1993 & 1993 & 1994 \\
\hline Agriculture & 47.4 & 53.7 & 49.8 & 54.4 & 64.7 & 65.4 & 75.5 \\
\hline Mining & 19.3 & 12.3 & 52 & 20.0 & 53.4 & 56.2 & 51.7 \\
\hline Industry & 219.7 & 224.6 & 245.3 & 265.8 & 326.8 & 329.6 & 419.9 \\
\hline Commerce and trade & 391.5 & 407.8 & 465.9 & 525.1 & 607.0 & 631.8 & 798.6 \\
\hline Consiruction & 399.1 & 422.7 & 436.3 & 463.2 & $\$ 13.7$ & 458.1 & 687.0 \\
\hline Transportation & 42.9 & 45.5 & 65.5 & 54.0 & 60.9 & 65.0 & 198.3 \\
\hline $\begin{array}{l}\text { Tourism. hotels. and } \\
\text { restaurants }\end{array}$ & 30.8 & 33.3 & 31.8 & 37.3 & 58.8 & 32.8 & 38.1 \\
\hline $\begin{array}{l}\text { Professional and } \\
\text { private indinduals }\end{array}$ & 253.8 & 288.5 & 318.8 & 375.3 & 415.0 & $\ldots$ & $\ldots$ \\
\hline Equity participation & 52.2 & 71.1 & 76.6 & 90.8 & 136.2 & $\ldots$ & $\ldots$ \\
\hline Financial setvices & & & & & & 174.8 & 175.3 \\
\hline Services and infrastruciure & & & & & & 43.6 & 150.5 \\
\hline Other credils & 75.7 & 110.8 & 110.2 & 100.8 & 204.4 & 884.0 & 653.5 \\
\hline Total !' & 1.5324 & 1.670 .3 & 1.805 .4 & 2.046 .7 & 244.9 & 2.741 .3 & 3.246 .4 \\
\hline $\begin{array}{l}\text { Or which: Privale serior } \\
\text { (Resident) }\end{array}$ & & & & & & 2.2322 & $2.00+9.8$ \\
\hline
\end{tabular}

Source: Central Bank of Jordan.

l' Excluding public and private corporate bonds. 
Table 45. Jordan: Amman Financial Market Indicators, 1989-94

\begin{tabular}{|c|c|c|c|c|c|c|}
\hline & 1989 & 1990 & 1991 & 1992 & 1993 & 1994 \\
\hline & \multicolumn{6}{|c|}{$\begin{array}{c}\text { Value of Trading } \\
\text { (In millions of Jordan dinars) }\end{array}$} \\
\hline $\begin{array}{l}\text { Manufacturing and mining } \\
\text { Banking and finance } \\
\text { Services } \\
\text { Insurance } \\
\text { Total }\end{array}$ & $\begin{array}{r}240.33 \\
85.47 \\
31.60 \\
7.84 \\
365.24\end{array}$ & $\begin{array}{r}158.02 \\
71.18 \\
30.78 \\
6.42 \\
266.40\end{array}$ & $\begin{array}{r}177.76 \\
75.52 \\
34.35 \\
4.79 \\
29242\end{array}$ & $\begin{array}{r}527.98 \\
202.86 \\
12261 \\
25.31 \\
878.76\end{array}$ & $\begin{array}{r}510.08 \\
28255 \\
107.79 \\
32.95 \\
933.37\end{array}$ & $\begin{array}{r}165.7 \\
186.79 \\
70.03 \\
7.85 \\
430.37\end{array}$ \\
\hline Total & \multicolumn{6}{|c|}{$\begin{array}{l}\text { Number of Traded Shares } \\
\text { (In millions) }\end{array}$} \\
\hline $\begin{array}{l}\text { Manufacturing and mining } \\
\text { Banking and finance } \\
\text { Services } \\
\text { Insurance } \\
\text { Total }\end{array}$ & $\begin{array}{r}129.72 \\
28.14 \\
30.75 \\
3.99 \\
19260\end{array}$ & $\begin{array}{r}70.97 \\
23.53 \\
36.36 \\
3.53 \\
134.39\end{array}$ & $\begin{array}{r}80.84 \\
35.90 \\
37.51 \\
2.57 \\
156.82\end{array}$ & $\begin{array}{r}168.05 \\
80.82 \\
86.53 \\
9.36 \\
344.76\end{array}$ & $\begin{array}{r}116.30 \\
69.89 \\
49.23 \\
8.89 \\
244.31\end{array}$ & $\begin{array}{r}47.8 \\
56.75 \\
26.98 \\
2.31 \\
133.84\end{array}$ \\
\hline Total & \multicolumn{6}{|c|}{$\begin{array}{l}\text { Traded Shares Price Index } 1 / \\
\qquad(1991=100)\end{array}$} \\
\hline $\begin{array}{l}\text { Manufacturing and mining } \\
\text { Banking and finance } \\
\text { Services } \\
\text { Insurance }\end{array}$ & $\begin{array}{r}83.1 \\
106.9 \\
93.5 \\
91.3\end{array}$ & $\begin{array}{l}73.1 \\
92.8 \\
80.1 \\
77.1\end{array}$ & $\begin{array}{l}100 \\
100 \\
100 \\
100\end{array}$ & $\begin{array}{l}145.2 \\
115.6 \\
161.3 \\
144.0\end{array}$ & $\begin{array}{l}154.2 \\
164.2 \\
143.7 \\
159.8\end{array}$ & $\begin{array}{r}128 \\
157.8 \\
131.4 \\
138.2\end{array}$ \\
\hline General Index & 93.3 & 80.4 & 100 & 129.9 & 158.5 & 143.5 \\
\hline
\end{tabular}

Source: Amman Financial Market.

y Weighted by the number of traded shares; annual averages. 
Table 46. Jardad: Bahnce of Paymentu, 1969-94

(In million of U.S. dollar)

\begin{tabular}{|c|c|c|c|c|c|c|}
\hline & 1989 & 1990 & 1991 & 1992 & 1993 & $\begin{array}{r}\text { Prelia. } \\
\text { Actuats } \\
1994\end{array}$ \\
\hline Ourreat eccount $y$ & -104 & -754 & -712 & -741 & -650 & -399 \\
\hline $\begin{array}{l}\text { Goode and eervice } \\
\text { Trade balance } \\
\text { Exports. f.o.b. } \\
\text { Imporis, c.i.f. } \\
\text { Foodatuffe } \\
\text { Oil and oil products } \\
\text { Other }\end{array}$ & $\begin{array}{r}-733 \\
-1,298 \\
1,110 \\
2,390 \\
369 \\
415 \\
1,614\end{array}$ & $\begin{array}{r}-1,176 \\
-1,618 \\
1,064 \\
2,732 \\
619 \\
146 \\
1,657\end{array}$ & $\begin{array}{r}-897 \\
-1,439 \\
1,132 \\
2571 \\
613 \\
430 \\
1.528\end{array}$ & $\begin{array}{r}-1.247 \\
-2.119 \\
1.220 \\
3.339 \\
612 \\
446 \\
2.281\end{array}$ & $\begin{array}{r}-1,025 \\
-2,293 \\
1,248 \\
3,541 \\
628 \\
454 \\
2,459\end{array}$ & $\begin{array}{r}-725 \\
-1,950 \\
1,424 \\
3.374 \\
586 \\
430 \\
2,358\end{array}$ \\
\hline Service (bet) & sss & 493 & 543 & 873 & 1268 & 1.225 \\
\hline Remitunces (net) & 533 & 430 & 389 & 741 & 962 & 1.000 \\
\hline $\begin{array}{l}\text { Receipls } \\
\text { Payments }\end{array}$ & $\begin{array}{r}623 \\
91\end{array}$ & $\begin{array}{r}500 \\
71\end{array}$ & $\begin{array}{r}450 \\
61\end{array}$ & $\begin{array}{r}800 \\
86\end{array}$ & $\begin{array}{r}1,040 \\
78\end{array}$ & $\begin{array}{r}1,093 \\
93\end{array}$ \\
\hline Travel (oet) & 126 & 176 & 35 & 112 & 218 & $\begin{array}{r}93 \\
188\end{array}$ \\
\hline Receipts & 547 & $\$ 12$ & 317 & 462 & 563 & $S 82$ \\
\hline Poyments & 422 & 336 & 282 & 350 & 345 & 394 \\
\hline Inveatment income (net) & -385 & -402 & -362 & -335 & -310 & -315 \\
\hline Receiple & 40 & 67 & 114 & 112 & 99 & 73 \\
\hline Payments & 425 & 470 & 477 & 47 & 409 & 388 \\
\hline Other (net) & 282 & 289 & 481 & 381 & 398 & 306 \\
\hline Receipu & 693 & 936 & 1,036 & 985 & 1.011 & 629 \\
\hline Paymeos & 412 & $\mathbf{6 4 7}$ & 553 & 604 & 613 & 323 \\
\hline Uarequited transter & 629 & 122 & 185 & 506 & 375 & 326 \\
\hline Privile & 30 & 29 & 21 & 158 & 35 & 2 \\
\hline Publix $\boldsymbol{y}$ & 59 & 393 & 164 & 348 & 340 & 324 \\
\hline Capital eccoust & -399 & -362 & 73 & 151 & -147 & -54 \\
\hline Public sector & -380 & -431 & -672 & -337 & -415 & -271 \\
\hline Disburemenle $\mathbf{y}$ & 574 & 439 & 135 & 335 & 155 & 242 \\
\hline $\begin{array}{l}\text { Paymeals } \\
\text { Privale coctor (net) }\end{array}$ & 954 & $\begin{array}{r}-871 \\
69\end{array}$ & $-\frac{806}{26}$ & -672 & -570 & -513 \\
\hline Costs of restructuriag & -19 & 6 & 26 & 45 & 20 & $\begin{array}{r}26 \\
-35\end{array}$ \\
\hline Tranefers of worters enving & - & 112 & 719 & $\begin{array}{r}-158 \\
600\end{array}$ & 238 & 220 \\
\hline Errors and ominaione & 82 & 243 & 372 & 102 & 226 & 17 \\
\hline Overall balance & -421 & -760 & -267 & -488 & -571 & -430 \\
\hline Finacias & 421 & 760 & 267 & 488 & 571 & 436 \\
\hline IMF (met) & 47 & -9 & -- & 31 & -41 & 57 \\
\hline AMF (net) & 4 & -2 & -7 & -9 & -7 & 13 \\
\hline Exceptional cources. & $\boldsymbol{Q}$ & 1.114 & 1.368 & 517 & $\$ 24$ & 424 \\
\hline GCFOG prents and bones & -- & 327 & 726 & 28 & 35 & o \\
\hline Change is overdue obligations & 62 & 177 & Sw & -660 & -113 & 0 \\
\hline Debe reachoduling & 62 & 610 & 98 & 1.149 & 602 & 424 \\
\hline Change in NFA ( - = increane) $5 /$ & -314 & -342 & $-1,094$ & -51 & 95 & -58 \\
\hline Financing sap & & -- & -- & -- & -- & -- \\
\hline \multicolumn{7}{|l|}{ Meworaodurn ilems: } \\
\hline Qurreat ecounat balance $y$ (in percent of GDP) & -2.5 & -19.1 & -17.0 & -14.4 & -11.6 & -6.5 \\
\hline $\begin{array}{l}\text { Central Bank reserve of } \\
\text { (In monthe of seoports) }]\end{array}$ & $\begin{array}{r}48.0 \\
02\end{array}$ & $\begin{array}{r}221.0 \\
1.0\end{array}$ & $\begin{array}{r}825.0 \\
3.8\end{array}$ & $\begin{array}{r}769.9 \\
2.4\end{array}$ & $\begin{array}{r}5952 \\
22\end{array}$ & $\begin{array}{r}431.2 \\
1.5\end{array}$ \\
\hline
\end{tabular}

Sources: The Jordeaian authorities; and staff eatimates and projections.

y Eucluding transfers of envinge by Jordanian workers, and grasts trow the GCFOO.

2' Excludias prads trom the GOFOG, which are shown a part of the exceptional financing.

3. Excludias loans from the GCFOG, which se chown as part of the exeptional financing.

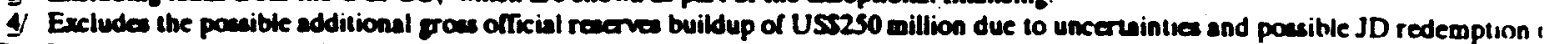
This fiasecing gap is expected to be covered by the requented augmenution of soces under the EFF, equivelent to 30 parcent of quou (: and World Bank propram lending.

5/ Cunge in NFA of the banking syatem.

9. Grou foreigo exchange reserves of the CBJ; excluding foreign achange deposits by reaidentu at the CBJ, gold, and claims nn the I dals are for end of pariod.

7 Importe of goods adjusted for re - exports 
Table 47. Jordan: Merchnndive Exports, 1909-94

\begin{tabular}{|c|c|c|c|c|c|c|}
\hline & 1939 & 1990 & 1991 & 1992 & 1993 & $\begin{array}{r}\text { Prel. } \\
\text { Acturits } \\
1994\end{array}$ \\
\hline & \multicolumn{6}{|c|}{ (In millions of U.S. Dollors) } \\
\hline 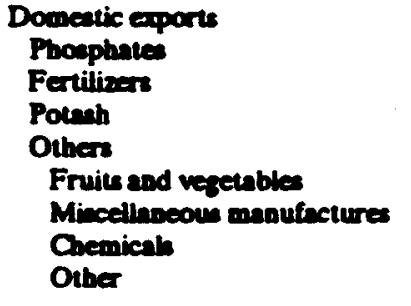 & $\begin{array}{r}929.1 \\
254.6 \\
119.7 \\
123.9 \\
430.8 \\
56.6 \\
172.7 \\
151.3 \\
50.3\end{array}$ & $\begin{array}{r}922.7 \\
209.0 \\
119.7 \\
133.4 \\
460.6 \\
67.4 \\
185.6 \\
165.2 \\
42.4\end{array}$ & $\begin{array}{r}879.4 \\
180.8 \\
127.1 \\
142.2 \\
429.3 \\
80.1 \\
1432 \\
133.1 \\
72.9\end{array}$ & $\begin{array}{r}932.3 \\
180.1 \\
106.6 \\
126.8 \\
518.8 \\
73.5 \\
176.3 \\
183.1 \\
85.9\end{array}$ & $\begin{array}{r}997.8 \\
141.3 \\
80.3 \\
124.2 \\
652.0 \\
99.8 \\
227.4 \\
201.8 \\
123.0\end{array}$ & $\begin{array}{r}1,136.1 \\
143.7 \\
127.6 \\
132.5 \\
732.3 \\
93.4 \\
237.3 \\
247.8 \\
53.8\end{array}$ \\
\hline Re-exports & 180.1 & 141.4 & 252.8 & 287.6 & 2502 & 288.0 \\
\hline \multirow[t]{2}{*}{ Tosal } & 1.1092 & $1,064.1$ & 1,1322 & 1.219 .9 & 12480 & 1.424 .1 \\
\hline & \multicolumn{6}{|c|}{ (Annual percenure changes) } \\
\hline $\begin{array}{l}\text { Domeatic expare } \\
\text { Phosphates } \\
\text { Ferilizars } \\
\text { Potsab } \\
\text { Others } \\
\text { Fruits and vegetables } \\
\text { Mincellaweous manufectures } \\
\text { Oremicals } \\
\text { Other }\end{array}$ & $\begin{array}{r}7.4 \\
24.6 \\
-8.1 \\
-30.9 \\
22.7 \\
8.4 \\
22.6 \\
33.1 \\
13.0\end{array}$ & $\begin{array}{r}-0.7 \\
-17.9 \\
-7 \\
7.7 \\
6.9 \\
19.1 \\
7.5 \\
92 \\
15.7\end{array}$ & $\begin{array}{r}-4.7 \\
-13.5 \\
6.2 \\
6.6 \\
-6.8 \\
18.8 \\
-22.8 \\
-19.4 \\
71.9\end{array}$ & $\begin{array}{r}6.0 \\
-0.4 \\
-16.1 \\
-10.8 \\
20.9 \\
-8.2 \\
23.1 \\
37.6 \\
17.8\end{array}$ & $\begin{array}{r}7.0 \\
-21.5 \\
-24.7 \\
-2.1 \\
25.7 \\
35.8 \\
29.0 \\
10.2 \\
43.2\end{array}$ & $\begin{array}{r}13.9 \\
1.7 \\
58.9 \\
6.7 \\
12.3 \\
-6.4 \\
4.4 \\
22.8 \\
25.0\end{array}$ \\
\hline Re-expors & 193 & -21.5 & 78.8 & 13.8 & -13.0 & 15.1 \\
\hline Toul & 92 & -4.1 & 6.4 & 7.7 & 23 & 14.1 \\
\hline
\end{tabular}

Source: Ceatral Back of Jordan. 
Table 48. Jordan: Merchnodise Importa, 1989-94

\begin{tabular}{|c|c|c|c|c|c|c|}
\hline & 1989 & 1990 & 1991 & $1992 \underline{1 /}$ & 1993 & $\begin{array}{r}\text { Prel. } \\
\text { Acluals } \\
199.4\end{array}$ \\
\hline & \multicolumn{6}{|c|}{ (In millions of U.S. dollars) } \\
\hline Total impons, c.i.f. & $2,398.5$ & 2,7321 & $2,571.3$ & $3,339.0$ & 3.541 .3 & 3.380 .9 \\
\hline Food and live animals & 369.4 & 608.7 & 613.5 & 612.0 & 628.0 & 586.2 \\
\hline Bevernges and tobacco & 16.6 & 14.8 & 14.0 & 13.7 & 13.9 & 19.9 \\
\hline Raw materials & 76.0 & 65.1 & 86.5 & 67.0 & 80.1 & 1024 \\
\hline Petroleum, fuels, and lubricants & 415.5 & 470.3 & 429.5 & 446.3 & 454.3 & 4.30 .2 \\
\hline Of which: crude oil & 320.0 & 355.8 & 350.5 & 336.6 & 341.3 & $33: .5$ \\
\hline Oils and tats & 13.5 & 33.0 & 34.8 & 55.4 & 61.6 & $11 k .1$ \\
\hline Chemicals & 250.9 & 286.6 & 321.4 & 361.2 & 358.8 & 400.0 \\
\hline $\begin{array}{l}\text { Manufactured goods } \\
\text { Machinery and transport }\end{array}$ & 421.3 & 451.6 & 481.5 & 654.4 & 731.4 & 618.4 \\
\hline equipment & 483.4 & 493.1 & 439.3 & 891.1 & 953.8 & 859.1 \\
\hline Other manufacturers & 158.6 & 138.8 & 137.9 & 222.3 & 217.6 & 217.0 \\
\hline Commoditiex n.e.s. & 68.6 & 38.7 & 13.0 & 15.6 & 41.8 & 29.0 \\
\hline \multirow[t]{2}{*}{ Aircraft leaset } & 138.0 & 148.0 & -- & -- & & \\
\hline & \multicolumn{6}{|c|}{ (Appual percentage changes) } \\
\hline Total impors, c.i.f. & -11.7 & 13.9 & -5.9 & 29.9 & 6.1 & -4.5 \\
\hline Food and live animais & -19.8 & 64.8 & 0.8 & -0.2 & 2.6 & -0.7 \\
\hline Beverages and tobacco & -8.3 & -10.8 & -5.4 & -2.1 & 1.5 & 4.2 \\
\hline Raw materials & -24.1 & -14.3 & 32.9 & -22.5 & 19.6 & 27.8 \\
\hline Petroleum, fuels, and lubricants & -1.1 & 13.2 & -8.7 & 3.9 & 1.8 & -5.3 \\
\hline Of which: crude oil & -5.5 & 11.1 & -1.5 & -4.0 & 1.4 & -2.0 \\
\hline Oils and fals & -53.4 & 144.4 & 5.5 & 59.2 & 11.2 & 917 \\
\hline Chemicals & -6.2 & 14.2 & 12.1 & 12.4 & -0.7 & 11.0 \\
\hline $\begin{array}{l}\text { Manufaciured goods } \\
\text { Machinery and Iranspon }\end{array}$ & -10.7 & 7.2 & 6.6 & 35.9 & 11.8 & -154 \\
\hline equipenent & -22.3 & 2.0 & -10.9 & 102.8 & 7.0 & -99 \\
\hline Other manufacturers & -21.0 & -12.5 & -0.6 & 61.2 & -2.1 & -0.3 \\
\hline Commoditiex n.e.s. & -48.3 & -43.6 & -66.4 & 20.0 & 167.9 & -30.0 \\
\hline
\end{tabular}

Source: Central Bank of Jorden.

1/ Including US\$91 million of vehicles and US\$136 million of other consumer durable goods brought into Jordan hy Jordanians rı from shroad in the aftermath of the 1990 regional crisis. 
Table 49. Jordan: External Services Account, 1989-94

(In millions of U.S. dollars)

\begin{tabular}{|c|c|c|c|c|c|c|}
\hline & 1989 & 1990 & 1991 & 1992 & 1993 & $\begin{array}{r}\text { Prel. } \\
\text { Actuals } \\
1994\end{array}$ \\
\hline $\begin{array}{l}\text { Net services } \\
\text { Factor services } \\
\text { Nonfactor services }\end{array}$ & $\begin{array}{l}555 \\
148 \\
407\end{array}$ & $\begin{array}{r}493 \\
28 \\
465\end{array}$ & $\begin{array}{r}543 \\
27 \\
516\end{array}$ & $\begin{array}{l}873 \\
379 \\
494\end{array}$ & $\begin{array}{r}1,268 \\
652 \\
616\end{array}$ & $\begin{array}{r}1225 \\
685 \\
540\end{array}$ \\
\hline $\begin{array}{l}\text { Receipts } \\
\text { Workers' remittances } 1 / \\
\text { Investment income } \\
\text { Travel } \\
\text { Transportation } \\
\text { Government, n.i.e. } \\
\text { Other }\end{array}$ & $\begin{array}{r}1,903 \\
623 \\
40 \\
547 \\
274 \\
18 \\
401\end{array}$ & $\begin{array}{r}2,015 \\
500 \\
67 \\
512 \\
369 \\
17 \\
550\end{array}$ & $\begin{array}{r}1,917 \\
450 \\
114 \\
317 \\
250 \\
19 \\
767\end{array}$ & $\begin{array}{r}2,359 \\
800 \\
112 \\
462 \\
329 \\
14 \\
642\end{array}$ & $\begin{array}{r}2,713 \\
1,040 \\
99 \\
563 \\
366 \\
14 \\
631\end{array}$ & $\begin{array}{r}2,727 \\
1,093 \\
73 \\
582 \\
350 \\
19 \\
610\end{array}$ \\
\hline $\begin{array}{l}\text { Payments } \\
\text { Workers' remittances } \\
\text { Investment income } \underline{2} \\
\text { Travel } \\
\text { Transportation } \\
\text { Government, n.i.e. } \\
\text { Other }\end{array}$ & $\begin{array}{r}1,350 \\
91 \\
425 \\
422 \\
240 \\
103 \\
69\end{array}$ & $\begin{array}{r}1,524 \\
71 \\
470 \\
336 \\
349 \\
150 \\
148\end{array}$ & $\begin{array}{r}1,375 \\
61 \\
477 \\
282 \\
169 \\
159 \\
227\end{array}$ & $\begin{array}{r}1,487 \\
86 \\
447 \\
350 \\
296 \\
157 \\
151\end{array}$ & $\begin{array}{r}1,445 \\
78 \\
409 \\
345 \\
299 \\
198 \\
116\end{array}$ & $\begin{array}{r}1,502 \\
93 \\
388 \\
394 \\
304 \\
196 \\
127\end{array}$ \\
\hline
\end{tabular}

Source: Central Bank of Jordan.

1/ Excludes transfers of savings from abrosd.

2/ On a commitment basis. 
Table 50. Jordan: Net Foreign Assets of the Banking System, 1989-94

(In millions of U.S. dollars)

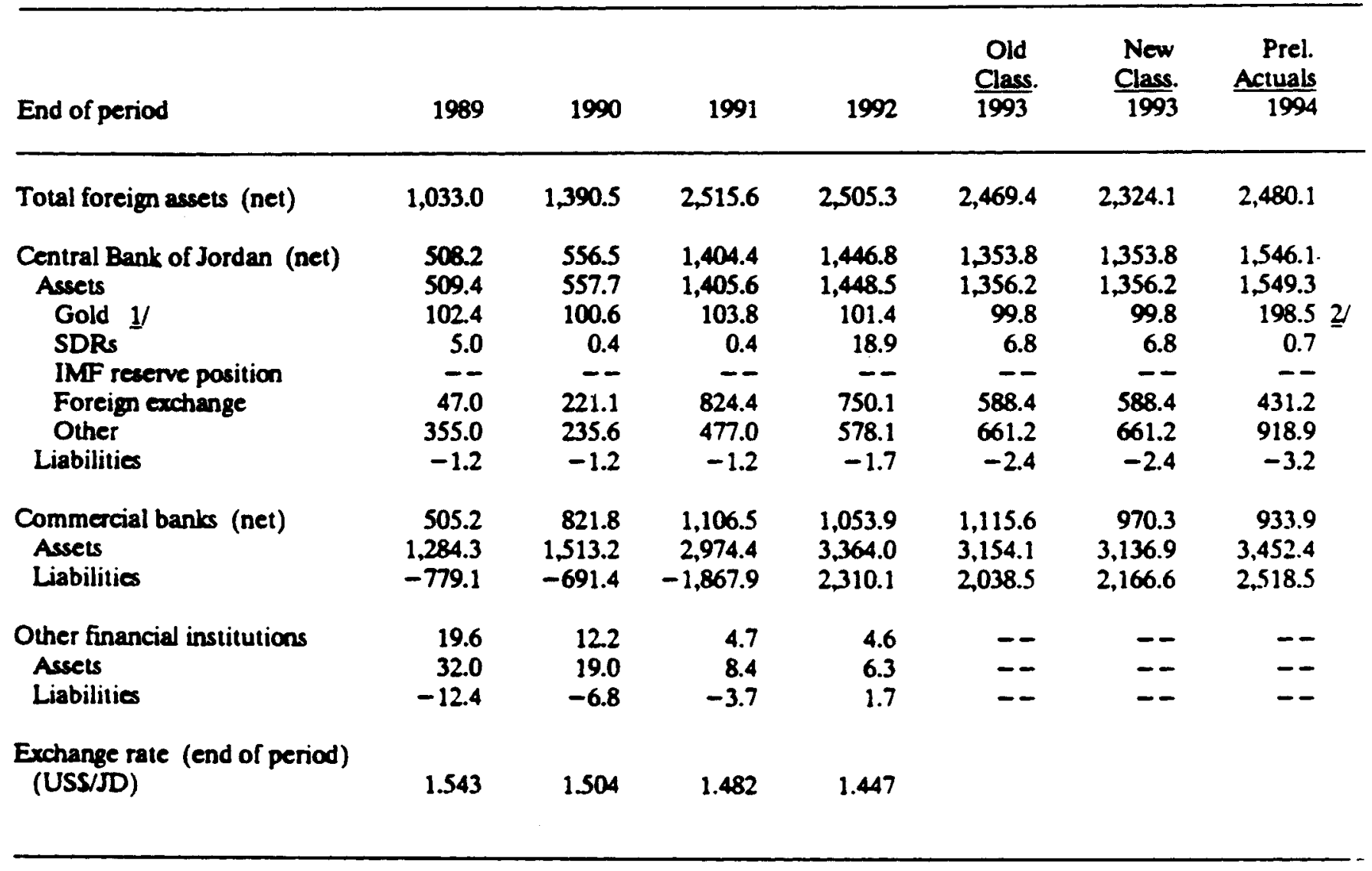

Source: Central Bank of Jordan.

$\underline{y}$ National valuation.

2 Includes U.S.\$97.9 million of revaluation. 
Table 51. Jordan: Terms of Trade, 1989-94

$$
(\underline{1985}=100)
$$

\begin{tabular}{lccc}
\hline & Exports & Imports & $\begin{array}{c}\text { Terms of } \\
\text { Trade }\end{array}$ \\
\hline & & (Unit Price Indices) & \\
1989 & & & 121.1 \\
1990 & 145.3 & 120.0 & 107.1 \\
1991 & 173.0 & 161.5 & 118.9 \\
1992 & 192.5 & 161.9 & 121.3 \\
1993 & 185.5 & 152.9 & 120.6 \\
1994 & 187.4 & 155.4 & 129.9 \\
& 196.3 & 151.1 & \\
1989 & & & \\
1990 & & (Unit Volume Indices) & \\
1991 & 144.0 & 95.4 & \\
1992 & 138.6 & 99.5 & \\
1993 & 121.8 & 98.3 & \\
1994 & 133.8 & 134.8 & \\
& 144.5 & 147.0 & \\
\hline
\end{tabular}

Source: Central Bank of Jordan. 
Table 52. Jordan: Composition of Imparts (SITC Cancification), 1989-94

(In millions of Jorda dinars)

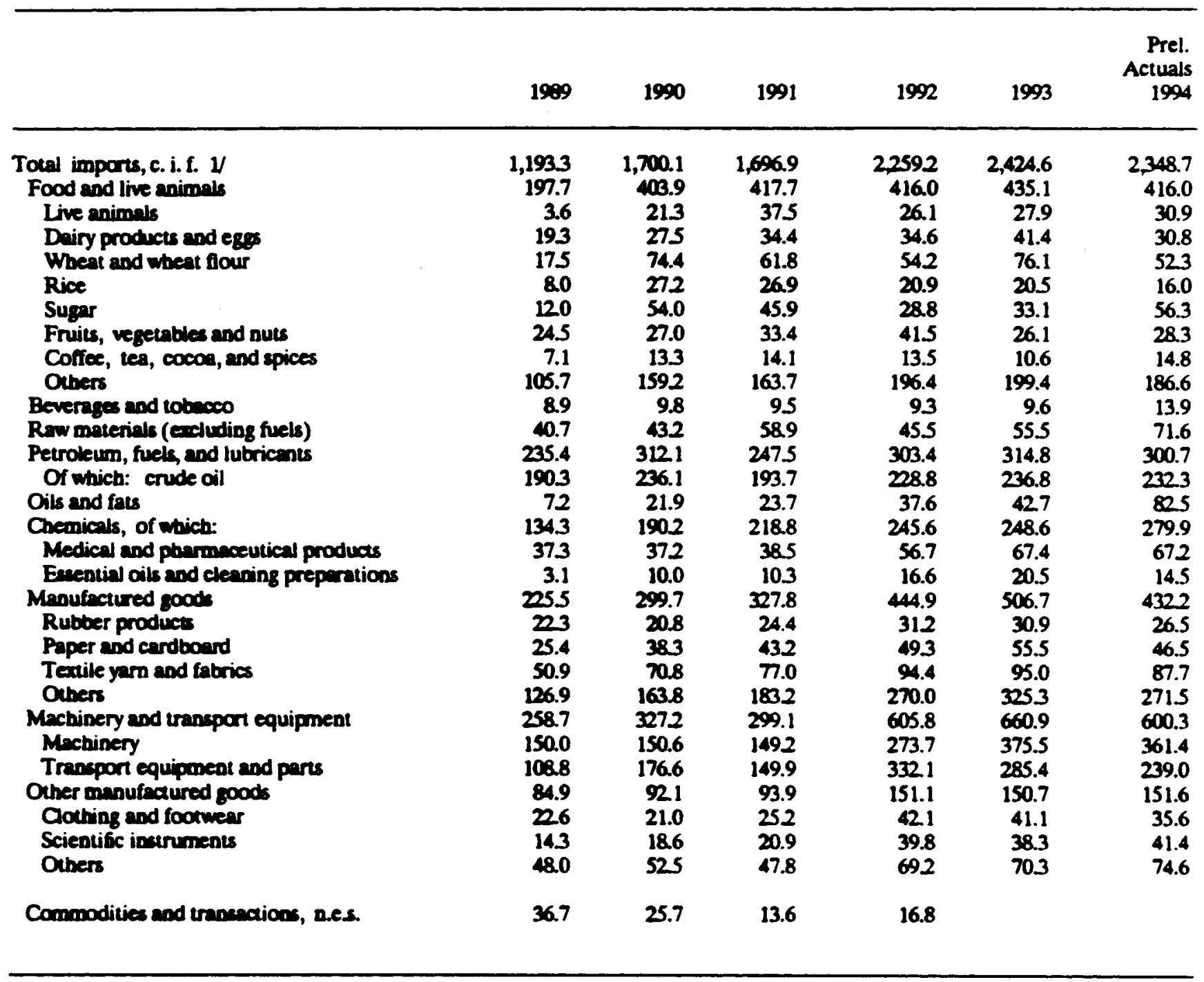

Source: Ceoural Bart of Jordm .

y Custams beris. 
Table 53. Jordan: Direcion of Foreign Trade, 1989-94

(In millions of Jordan dinars)

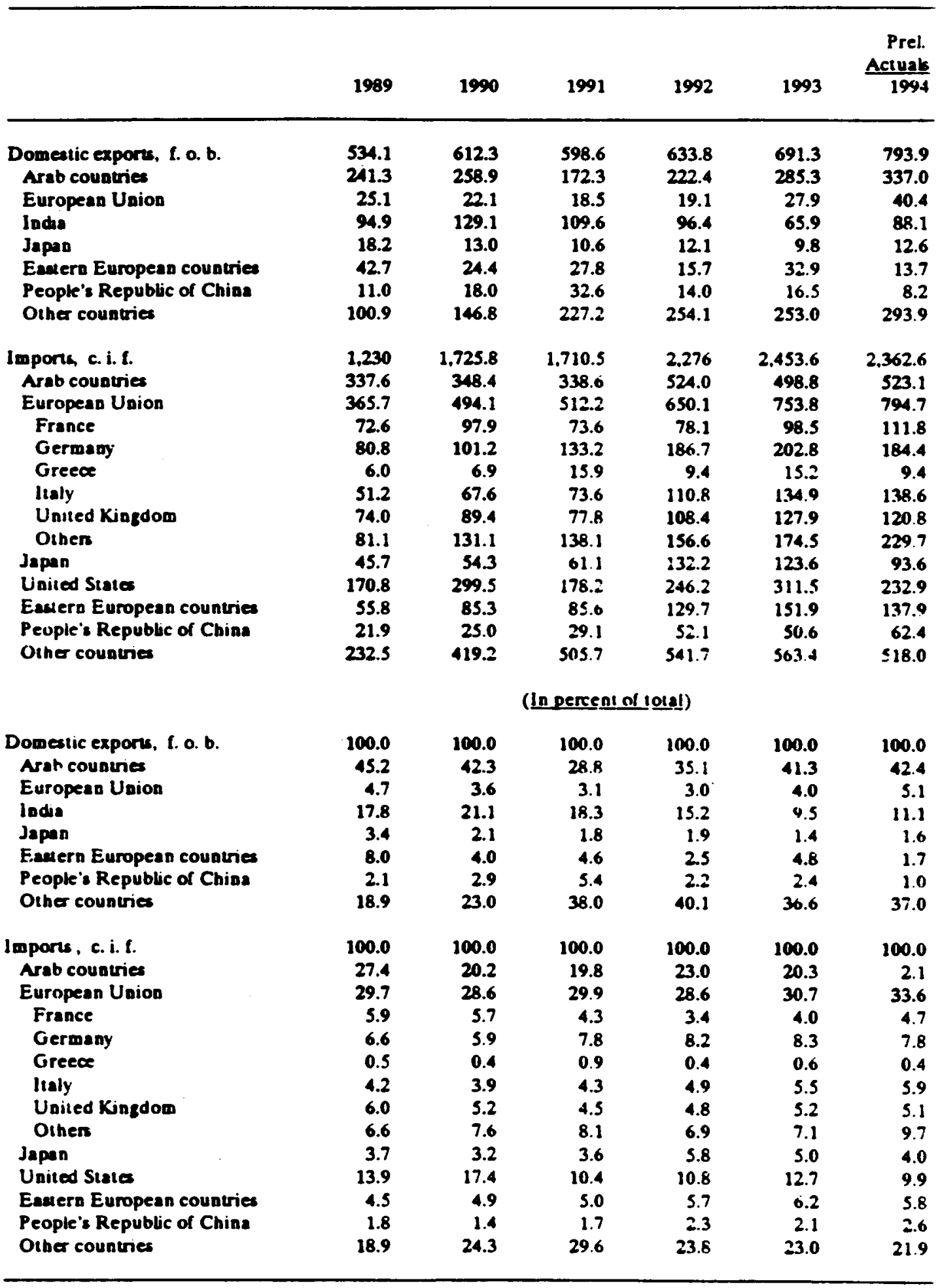

Source: Central Bank of Jordan. 
Table 54. Jordan: Official Transfers, 1989-1994

(In millions of U.S. dollars)

\begin{tabular}{|c|c|c|c|c|c|c|}
\hline & 1909 & 1990 & 1991 & 1992 & 1993 & $\begin{array}{r}\begin{array}{r}\text { Prel. } \\
\text { Actuals }\end{array} \\
1994\end{array}$ \\
\hline Bilateral grants & 537.0 & 47.0 & 177.0 & 270.0 & 194.4 & 1820 \\
\hline Arab countries 1 & 537.0 & 293.0 & 66.0 & 206.0 & 183.3 & 150.0 \\
\hline Saudi Arabia & 260.0 & 100.0 & - & - & - & - \\
\hline Kuwait & 1020 & 83.0 & - & -- & -- & - \\
\hline Iraq 2 & 71.0 & 45.0 & 66.0 & 206.0 & 183.3 & 150.0 \\
\hline United Arab Emirates & 80.0 & 60.0 & - & -- & -- & -- \\
\hline Oman & 25.0 & 5.0 & - & -- & $\ldots$ & - - \\
\hline Qatar & -- & 20.0 & -- & -- & -- & - \\
\hline Other countries $3 /$ & -- & 154.0 & 111.0 & 64.0 & 13.0 & 321 \\
\hline United Kingdom & -- & - & - & -- & - & - \\
\hline United States $\boldsymbol{\Psi}$ & -- & 20.0 & 18.0 & 320 & 13.0 & 18.0 \\
\hline Japan & -- & -- & $\ldots$ & -- & -- & 6.8 \\
\hline Germany & -- & 118.0 & 83.0 & -- & -- & -- \\
\hline laby & -- & - & - & 20 & -- & - \\
\hline France & -- & -- & - & $=-$ & -- & - \\
\hline Austria & -- & -- & - & 4.0 & -- & 3.0 \\
\hline Belgium & -- & -- & -- & -- & -- & -- \\
\hline Canada & -- & -- & 3.0 & 7.0 & -- & 4.3 \\
\hline Other & -- & 16.0 & 8.0 & 19.0 & -- & - \\
\hline European Union & -- & -- & 175.0 & 320 & 30.9 & 35.0 \\
\hline Emergency projects & -- & -- & 120 & 28.0 & 16.0 & - \\
\hline UN agencies & 620 & 80.0 & 80.0 & 46.0 & 113.1 & 106.7 \\
\hline Total grants & 599.0 & 527.0 & 44.0 & 376.0 & 356.3 & 323.8 \\
\hline Of which: GCFCG grants & $\ldots$ & 134.0 & 280.0 & 28.0 & 16.0 & - \\
\hline
\end{tabular}

Sources: The Jordanian authorities; and staff estimates.

1/ For 1990, all the grants from these countries were received before the month of Auguas 1990.

2 From 1991 onwards, the grants are in the form of petroleum impors from Irag at a lower price.

3. For 1990, all the grants from these countries were received after the month of August 1990.

4 Under commodity import program. 
Table 55. Jordan: Disbursement of External Public and Publicly Guaranteed Loans, 1990-94

(In millions of U.S. dollars)

\begin{tabular}{|c|c|c|c|c|c|}
\hline & 1990 & 1991 & 1992 & 1993 & $\begin{array}{r}\text { Prel. } \\
\text { Actuals } \\
1942\end{array}$ \\
\hline $\begin{array}{l}\text { Development loans } \\
\text { (Ministry of Planning) }\end{array}$ & 92.4 & 99.0 & 74.0 & 93.2 & 122 \\
\hline $\begin{array}{l}\text { Commodity loans } \\
\text { (Ministry of Supply) }\end{array}$ & 109.0 & 20.0 & 6.0 & 25.0 & 15 \\
\hline $\begin{array}{l}\text { Guaranteed loans } \\
\text { (multitateral organizations) }\end{array}$ & 16.3 & 13.4 & 10.0 & 15.0 & li: \\
\hline $\begin{array}{l}\text { GCFCG/bilateral offical loans } \\
\text { Germany } \\
\text { Japan } \\
\text { France } \\
\text { Other }\end{array}$ & $\begin{array}{l}193.2 \\
30.0 \mathrm{~J} \\
163.2 \mathrm{~J} \\
-\overline{--}\end{array}$ & $\begin{aligned}+6.0 \\
15.0 \mathrm{ll} \\
+14.0 \mathrm{li} \\
17.0 \mathrm{li} \\
--\end{aligned}$ & $\begin{array}{r}162.0 \\
7.0 \\
12.0 \\
21.0 \\
76.0\end{array}$ & $\begin{array}{l}19.3 \\
19.311 \\
-- \\
-- \\
--\end{array}$ & $\begin{array}{r}70.9 \\
4 \\
40 \\
70 \\
i 4\end{array}$ \\
\hline $\begin{array}{l}\text { IBRD adjustment loans } \\
\text { Trade and Industry Policy } \\
\text { Adjustment loan }\end{array}$ & $\begin{array}{l}73.3 \\
73.3\end{array}$ & -- & 76.0 & $\begin{array}{l}21.5 \\
21.5\end{array}$ & is \\
\hline IBRD emergency loan & -- & 3.0 & 7.11 & -- & -- \\
\hline Koyal Jordanian Airlines & 148.4 & -- & -- & -- & - \\
\hline Total & 6.32 .6 & 581.4 & 335.0 & 174.0 & 241.4 \\
\hline
\end{tabular}


Table 56. Jordan: Outstanding External Debt, End-December 1994 1/

(In millions of U.S. dollars)

\begin{tabular}{|c|c|c|c|}
\hline & \multicolumn{3}{|c|}{ End-December 1994} \\
\hline & Disbursed & Undisbursed & Total \\
\hline Arab countries & 356.0 & 145.3 & 501.3 \\
\hline Bilateral loans & 45.0 & -- & 45.0 \\
\hline Funds & 311.0 & 145.3 & 456.3 \\
\hline Industrial countries $2 /$ & $4,266.5$ & 396.5 & $4,663.0$ \\
\hline Bilateral loans & $2,067.7$ & 331.6 & $2,399.3$ \\
\hline Export credit guarantees & $2,198.8$ & 64.9 & $2,263.7$ \\
\hline Other countries & 34.8 & 5.4 & 39.4 \\
\hline International banks $\underline{3}$ / & 840.5 & -- & 840.5 \\
\hline Multilateral institutions & $1,047.5$ & 768.2 & $1,815.7$ \\
\hline Bretton Woods institutions & 748.0 & 250.9 & 998.9 \\
\hline Other multilateral & 299.5 & 517.3 & 816.8 \\
\hline Leases & 294.9 & -- & 294.9 \\
\hline Total & $6,840.3$ & $1,314.6$ & $8,154.9$ \\
\hline $\begin{array}{l}\text { Memorandum item: } \\
\text { Total debt (as percent of }\end{array}$ & & & \\
\hline
\end{tabular}

Source: Ministry of Finance and Customs.

$\underline{1} /$ Public and publicly guaranteed medium - and long - term debt.

$2 /$ Includes US\$651 million of par and discount exchange bonds, issued after the debt and deb which are fully collateralized. 
Table 57. Jordan: Service Payments on External Public Debi, 1989-94

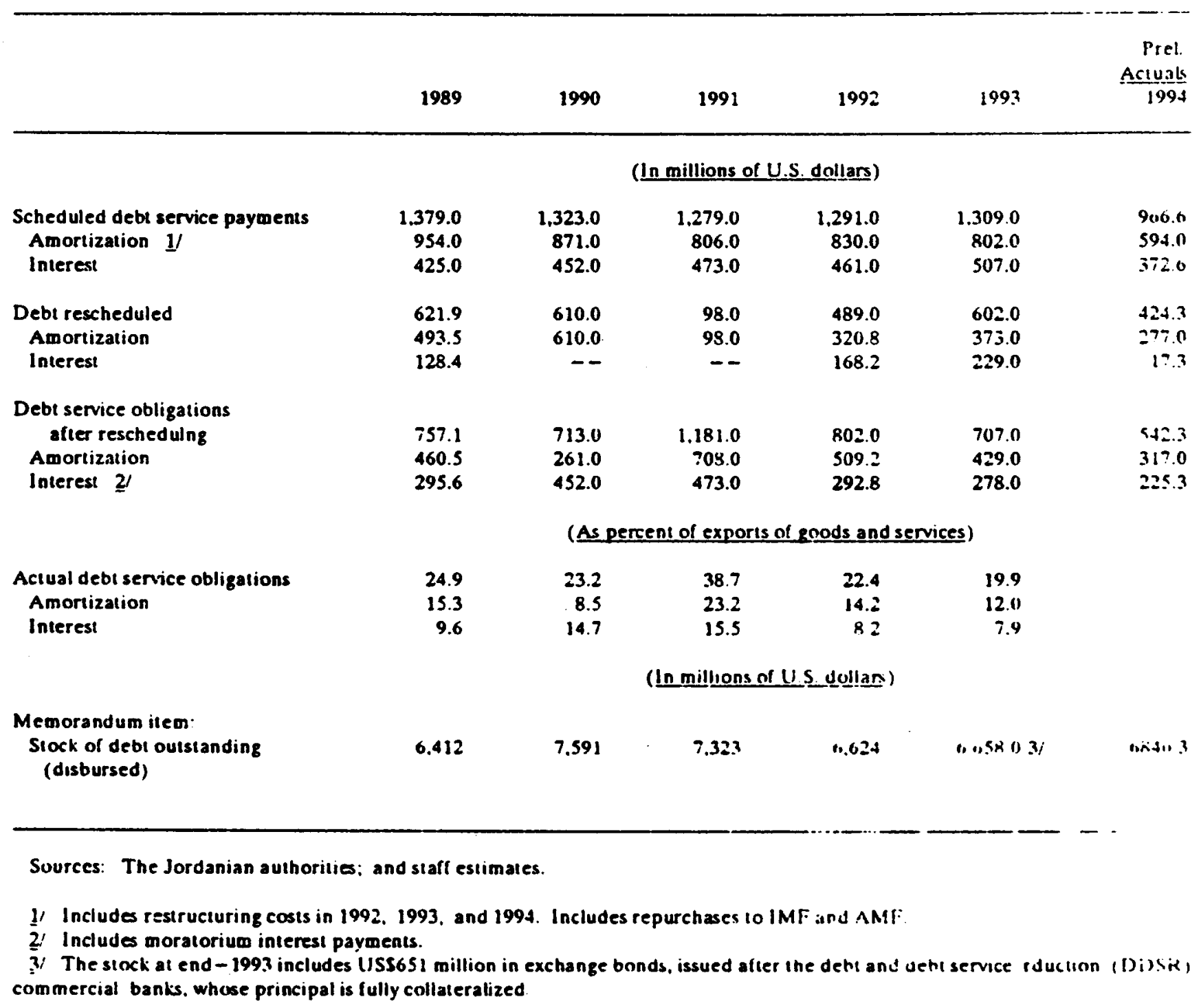

